\title{
HIV, EMPLOYMENT AND THE LAW: A SOCIO-LEGAL ANALYSIS OF THE LEGAL FRAMEWORK
}

\section{PETER OLIVER MICHAEL McTIGUE}

A thesis submitted in partial fulfilment of the requirements of Nottingham Trent University for the degree of Doctor of Philosophy

May 2019 
This work is the intellectual property of the author. You may copy up to 5\% of this work for private study, or personal, non-commercial research. Any re-use of the information contained within this document should be fully referenced, quoting the author, title, university, degree level and pagination. Queries or requests for any other use, or if a more substantial copy is required, should be directed in the owner(s) of the Intellectual Property Rights. 
For Catherine, Connor, Lucy and Samuel

'When the soul of a man is born in this country there are nets flung to it to hold it back from flight. You talk to me of nationality, language, religion. I shall try to fly by those nets.'

James Joyce, A Portrait of the Artist as a Young Man 


\section{ACKNOWLEDGEMENTS}

A PhD candidate always needs help, support and encouragement. I am fortunate enough to have had more than my fair share and so I have number of people to thank.

First, my supervisors Kay Wheat and Michael Keenan. Their guidance and wisdom kept me on track throughout this process. In addition, both showed enormous patience and diligence in their supervision. I would also like to thank Elizabeth Kirk for her insight and guidance which proved invaluable. Thanks must also go to Matthew Weait who offered support, advice and supervision at the early stages of this work. I would also like to thank the external examiners for taking the time to read and feedback on this work.

The help offered by the Terrence Higgins Trust, National AIDS Trust, NAM Aidsmap and African Health Policy Network was invaluable, especially with regards to the call for research participants. Special thanks must go to Yusef Azad, Mick Mason, Roger Peabody, Lisa Power and Jacqueline Stevenson from these organisations.

This work would not have been possible without the HIV positive individuals who came forward to be interviewed by me. They offered their time freely and often went out of their way to speak to me, a complete stranger, about one of the most personal aspects of their life. Although their responses have been anonymised, I can recall each and every face and name. To all of them, thank you.

I wish to thank to my family and, in particular, my wife Catherine. Her tireless enthusiasm kept me going throughout the entire $\mathrm{PhD}$ process. She offered me encouragement when I was at my lowest ebb and could see no end in sight to this piece of work. Thank you. 


\section{LIST OF ABBREVIATIONS}

\begin{tabular}{|c|c|}
\hline $\mathrm{ADA}$ & Americans with Disabilities Act 1990 \\
\hline AIDS & Acquired Immune Deficiency Syndrome \\
\hline $\mathrm{CDC}$ & Centers for Disease Control \\
\hline CJEU & Court of Justice of the European Union \\
\hline \multirow[t]{2}{*}{ UN CPRD } & United Nations Convention on the Rights of Persons with \\
\hline & Disabilities \\
\hline DDA 1995 & Disability Discrimination Act 1995 \\
\hline EA 2010 & Equality Act 2010 \\
\hline $\mathrm{EC}$ & European Community \\
\hline EHRC & Equality and Human Rights Commission \\
\hline EU & European Union \\
\hline HAART & Highly Active Antiretroviral Therapy \\
\hline HIV & Human Immunodeficiency Virus \\
\hline ILO & International Labour Organisation \\
\hline MSM & Men who have sex with men \\
\hline NAT & National AIDS Trust \\
\hline PLHA & People living with HIV or with AIDS \\
\hline STI & Sexually transmitted infection \\
\hline SOPHID & Survey of Prevalent HIV Infections Diagnosed \\
\hline TFEU & Treaty on the Functioning of the European Union \\
\hline THT & Terrence Higgins Trust \\
\hline UN & United Nations \\
\hline UNAIDS & Joint United Nations Programme on HIV/AIDS \\
\hline UK & United Kingdom \\
\hline
\end{tabular}




\section{$\underline{\text { ABSTRACT }}$}

This thesis is an attempt to make a sustained and critical contribution to a particular area of legal scholarship in the field of HIV and AIDS, namely the protection of People Living with HIV or with AIDS ('PLHA') from discrimination within employment.

Whilst there has been significant research into HIV and AIDS, little research has been conducted into the issue of PLHA within an employment relationship. It is however apparent that research into the area of PLHA within an employment relationship is urgently required. As treatments and therapies for the virus develop and improve, life expectancy is enhanced and HIV has started to be perceived by some as a long term chronic condition rather than an acute life threatening illness. Yet PLHA are still subject to significant amounts of stigma and discrimination due to common misconceptions about the nature of the virus. To combat this, the United Kingdom seeks to protect PLHA from discrimination by deeming them to be 'disabled' for the purposes of the Equality Act 2010 (EA 2010).

With these issues in mind, this thesis seeks to identify whether the current framework employed by the EA 2010, and the Act's designation of HIV as a disability, represents an adequate response to the common societal issues faced by PLHA and is consistent with international and European legal obligations. To do this, two distinct methodologies are employed. Firstly, a doctrinal, literature based approach and secondly, empirical research consisting of 20 semistructured face-to-face interviews with PLHA. The findings of the empirical research were used to critique the law from an external, non-doctrinal perspective and develop proposals for amendments to UK law which accorded with the wishes of PLHA whilst ensuring compliance with the UK's international and European legal obligations.

The thesis finds that when considered from a purely normative perspective, the designation of HIV as a disability by the EA 2010 appears to go beyond the UK's obligations in respect of its international and European legal obligations. Despite this, the empirical research indicates that the manner in which PLHA receive protection from discrimination under the EA 2010 requires reworking in order to reflect

more accurately the issues faced by PLHA. Consequently, the thesis argues that the automatic disability designation afforded to PLHA by paragraph 6 to Schedule 1 of the Equality Act 2010 ought to be removed and that PLHA can be adequately protected from discrimination by an amended definition of disability in the EA 2010 which accurately incorporates the social model of disability into domestic law. 


\section{CONTENTS}

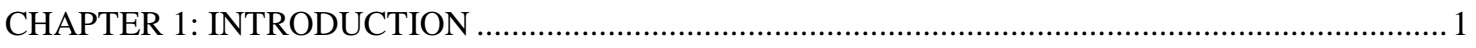

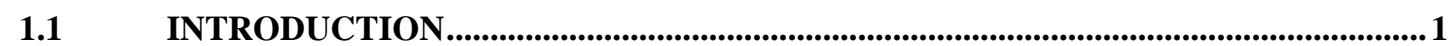

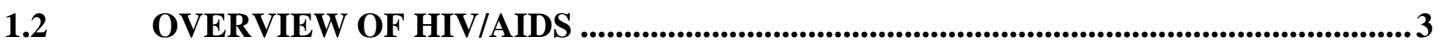

1.3 STIGMA

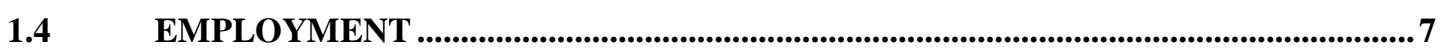

1.5 RESEARCH HYPOTHESIS AND STUCTURE ……..........................................................10

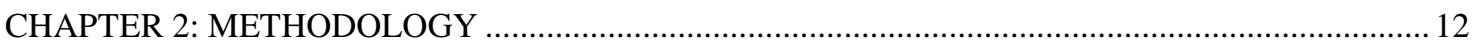

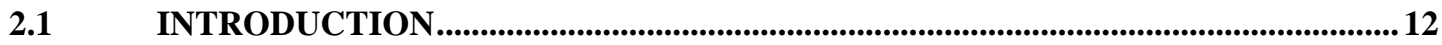

2.2 PHILOSOPHICAL PERSPECTIVE ……............................................................................ 12

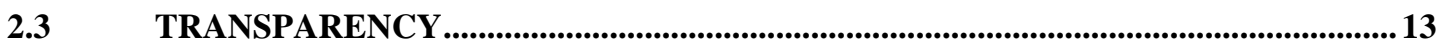

2.4 DOCTRINAL METHODOLOGY ….................................................................................16

2.5 EMPIRICAL METHODOLGY ......................................................................................... 18

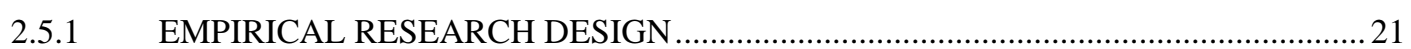

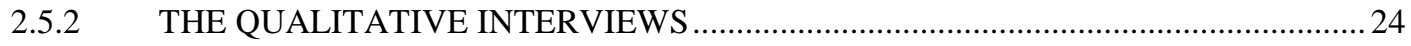

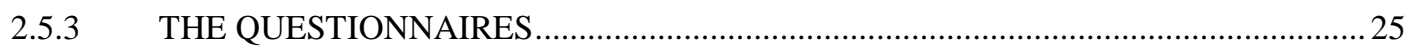

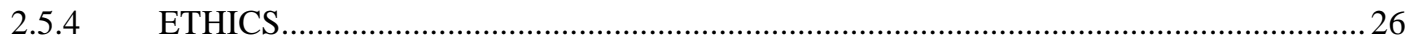

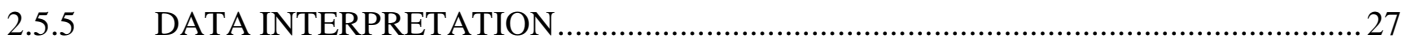

2.6 COMBINING THE DOCTRINAL AND EMPIRICAL FINDINGS ..............................28

CHAPTER 3: THE INTERNATIONAL AND EUROPEAN LEGAL FRAMEWORK RELATING TO

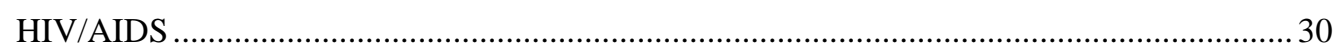

3.1 INTRODUCTION....................................................................................................................30

3.2 GLOBAL CONVENTIONS AND POLICY ............................................................

3.2.1 INTERNATIONAL COVENANT ON ECONOMIC, SOCIAL AND CULTURAL

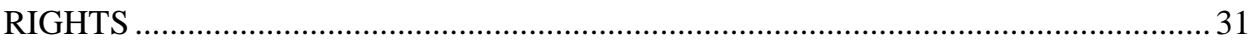

3.2.2 INTERNATIONAL COVENANT ON CIVIL AND POLITICAL RIGHTS ....................33

3.2.3 INTERNATIONAL GUIDELINES ON HIV/AIDS AND HUMAN RIGHTS ................. 35

3.2.4 THE ILO CODE OF PRACTICE ON HIV/AIDS AND THE WORLD OF WORK....... 37

3.2.5 THE UN CONVENTION ON THE RIGHTS OF PERSONS WITH DISABILITIES ... 39

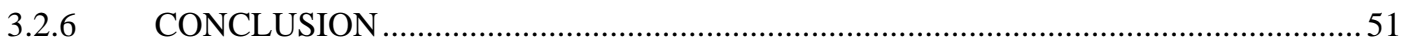


THE EUROPEAN CONVENTION ON HUMAN RIGHTS

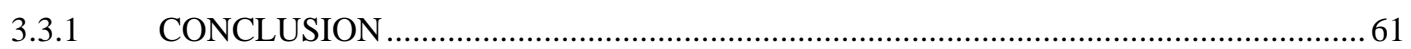

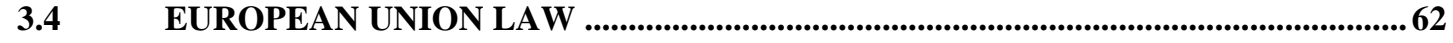

3.4.1 THE DEFINITION OF DISABILITY UNDER THE FRAMEWORK DIRECTIVE..... 66

3.4.2 PROHIBITED CONDUCT UNDER THE FRAMEWORK DIRECTIVE.................... 75

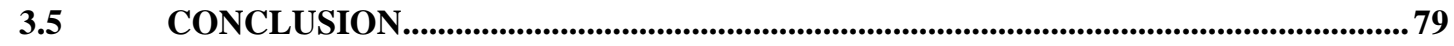

CHAPTER 4: THE DOMESTIC LEGAL FRAMEWORK RELATING TO HIV/AIDS .......................81

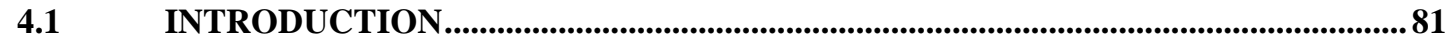

4.2 THE DEFINITION OF DISABILITY UNDER THE EQUALITY ACT ....................82

4.3 PROHIBITED CONDUCT UNDER THE EQUALITY ACT ....................................88

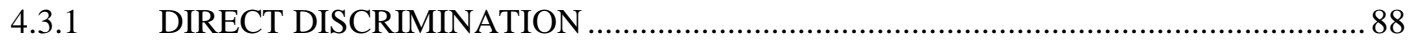

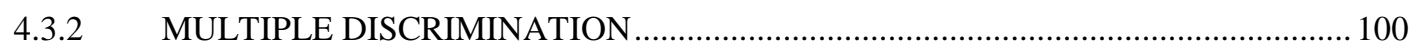

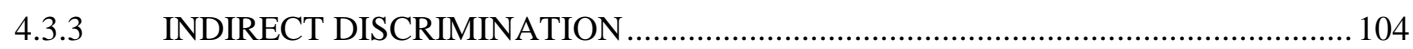

4.3.4 DISCRIMINATION ARISING FROM A DISABILITY ........................................ 108

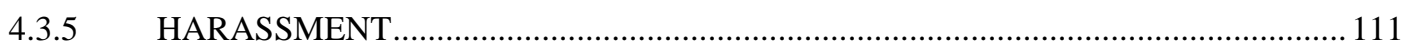

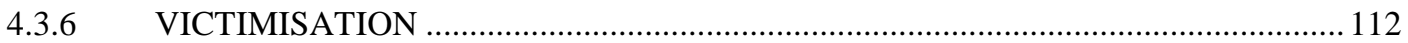

4.3.7 DUTY TO MAKE REASONABLE ADJUSTMENTS ......................................... 113

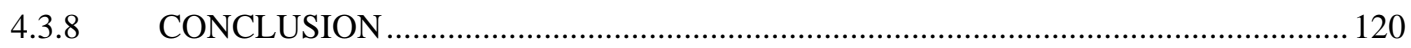

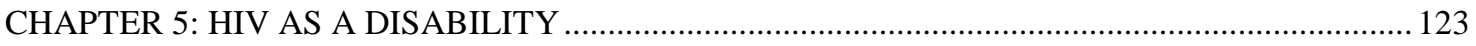

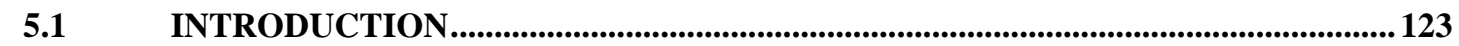

5.2 THE DISABILITY RIGHTS TASK FORCE........................................................... 123

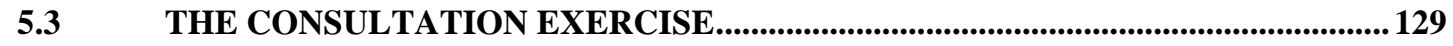

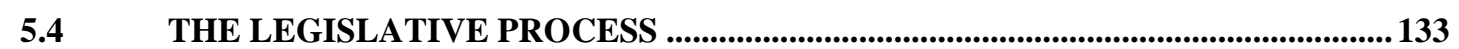

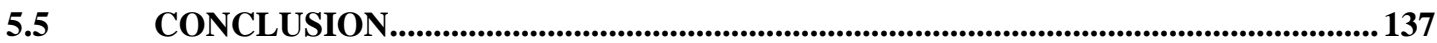

CHAPTER 6: EMPIRICAL FINDINGS - SOCIOLOGICAL THEMES .......................................... 140

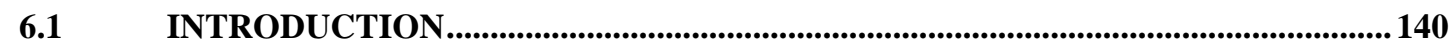

6.2 PUBLIC ATTITUDES TO HIV AND AIDS ........................................................... 143

6.2.1 LACK OF KNOWLEDGE IN THE GENERAL PUBLIC .......................................... 143

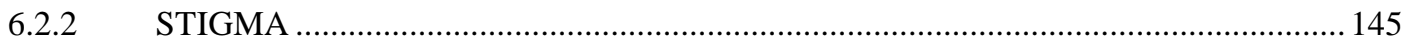

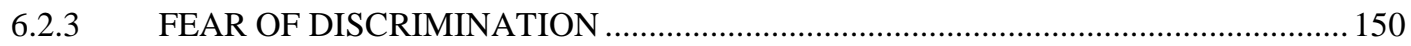

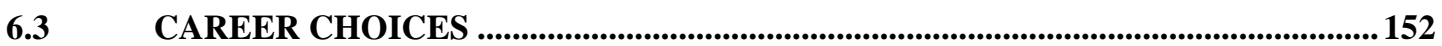




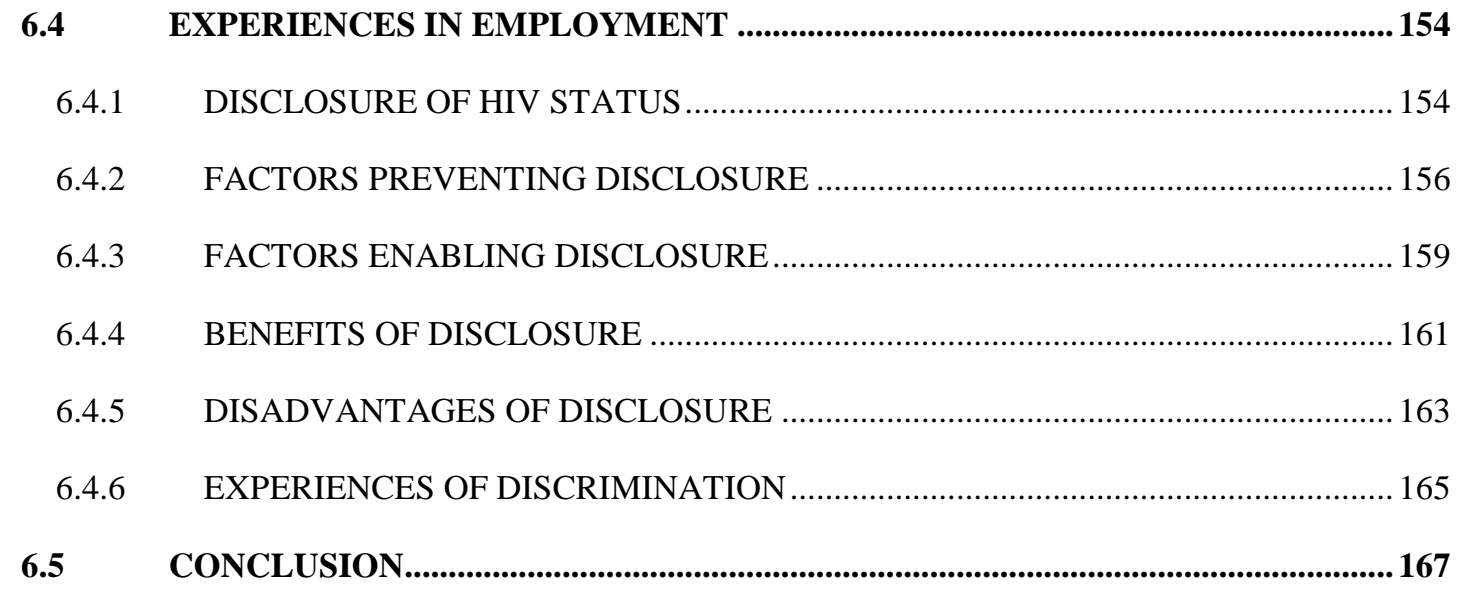

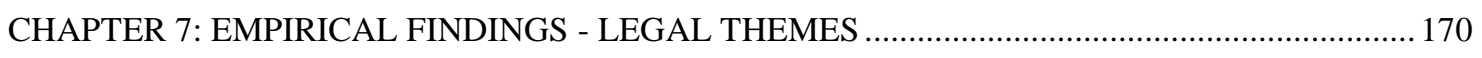

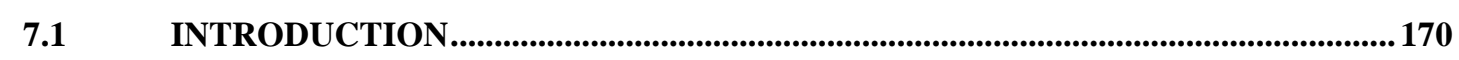

7.2 AWARENESS OF THE LEGAL FRAMEWORK ......................................................... 171

7.3 AWARENESS AND EXPERIENCES OF PLHA IN RELATION TO REASONABLE ADJUSTMENTS ............................................................................................................. 174

7.4 ATTITUDES OF PARTICIPANTS TO HIV BEING DEEMED A DISABILITY BY THE EA 2010....................................................................................................................................... 185

CONCLUSION................................................................................................................... 192

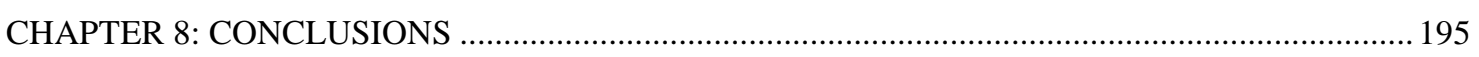

8.1 INTRODUCTION ............................................................................................................. 195

8.2 THE MANNER IN WHICH PLHA ARE PROTECTED: THE EQUALITY ACT'S DESIGNATION OF PLHA AS DISABLED ....................................................................197

8.3 THE CONDUCT WHICH PLHA ARE PROTECTED FROM: THE EQUALITY ACT'S FRAMEWORK OF PROHIBITED CONDUCT ..................................................205

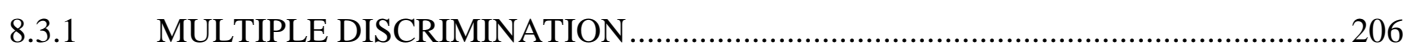

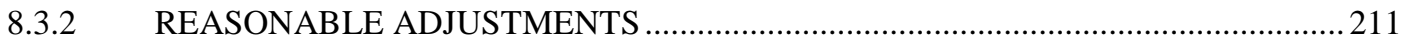

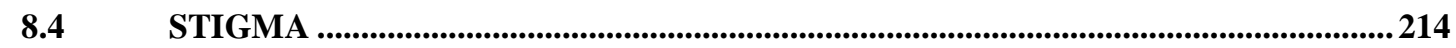

8.5 CONTRIBUTION TO EXISTING LEGAL SCHOLARSHIP ....................................216

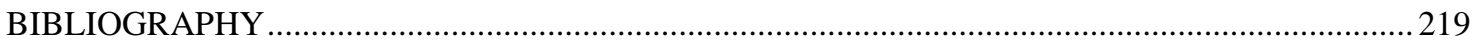

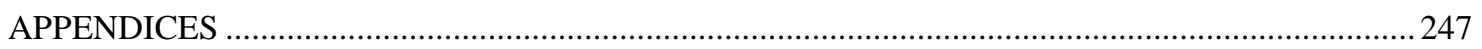

APPENDIX 1: CORRESPONDENCE FROM OFFICE FOR DISABILITY ISSUES DATED 12

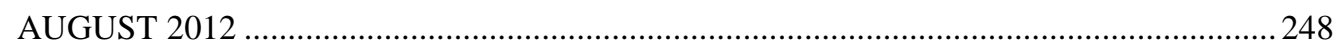

APPENDIX 2: CORRESPONDENCE FROM OFFICE FOR DISABILITY ISSUES DATED 20

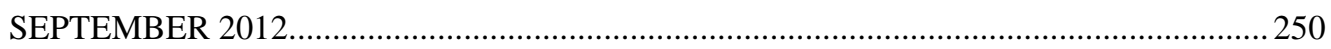


APPENDIX 3: TIMELINE OF THE PASSAGE OF THE DISABILITY DISCRIMINATION BILL 2005

APPENDIX 4: NAM AIDSMAP CALL FOR RESEARCH PARTICIPANTS ......................................257

APPENDIX 5: THT CALL FOR RESEARCH PARTICIPANTS ………................................................ 261

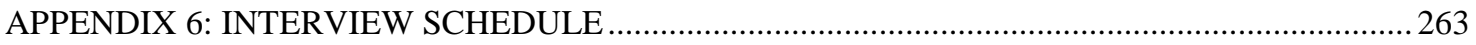

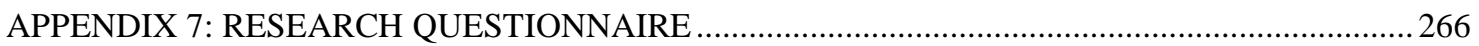

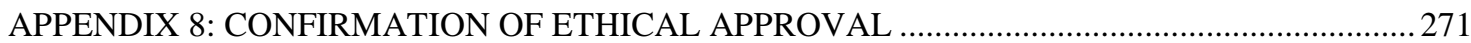

APPENDIX 9: RESEARCH BACKGROUND AND INFORMATION SHEET ………………….......22

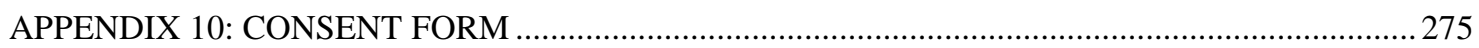




\section{CHAPTER 1: INTRODUCTION}

\subsection{INTRODUCTION}

It is estimated that there were 101,600 people living with HIV in the UK in $2017 .{ }^{1}$ In terms of groups affected in the UK, the virus disproportionately affects Men who have sex with Men (MSM) and black Africans. ${ }^{2}$ The objective of this work is to explore and critically evaluate the extent to which the Equality Act 2010 (EA 2010) protects these individuals within an employment relationship from discrimination. Specifically it seeks to identify whether the current framework employed by the EA 2010, and the Act's designation of HIV as a disability, represents an adequate response to the common societal issues faced by People Living with HIV or with AIDS (PLHA) and is consistent with international and European legal obligations. In the event that the EA 2010 is found to be inadequate, recommendations will be outlined detailing how to refine legal protection for PLHA in this area in order to ensure that the UK's approach accords with both the experiences and wishes of PLHA and the UK's legal obligations. This review is timely because (as discussed in sections 1.3 and 1.4) recent advances in treatment have led to significant improvements in PLHA's life expectancy and ability to maintain employment. ${ }^{3}$

This research is also required as there is a gap in the literature with regard to the issue. From a legal perspective, literature in the field is dominated by the issue of the criminalisation of HIV transmission. ${ }^{4}$ There is some HIV specific legal literature, but it predates the passage of the EA

Public Health England, 'Progress towards ending the HIV epidemic in the United Kingdom: 2018 report' (Public Health England 2018), 7.

48,900 MSM were estimated to be living with HIV in the UK in 2017. In addition, of the 18,400 heterosexual men and 29,000 heterosexual women estimated to be living with HIV in the UK in 2017, 8,600 were black African men and 18,500 were black African women . See Public Health England, 'Progress towards ending the HIV epidemic in the United Kingdom: 2018 report' (Public Health England 2018), 39.

R Dray-Spira and others, 'Socioeconomic differences in the impact of HIV infection on workforce participation in France in the era of Highly Active Antiretroviral Therapy' (2007) 97 (3) American Journal of Public Health 552; British HIV Association, 'British HIV Association guidelines for the treatment of HIV-1-positive adults with antiretroviral therapy 2015' (2016 interim update BHIVA 2015)

<http://www.bhiva.org/documents/Guidelines/Treatment/2016/treatment-guidelines-2016-interim-update.pdf> accessed 16 November 2017.

See for example M Weait, 'Criminal Law and the Sexual Transmission of HIV' (2007) 68 (1) The Modern Law Review 121; M Weait, Intimacy and Responsibility: The Criminalisation of HIV Transmission (Routledge 2007); C Dodds, 
$2010 .^{5}$ With regard to the EA 2010, whilst there are numerous general texts and articles concerning the Act, ${ }^{6}$ there is little research concerning disability within the context of the Act. Thus, when the Act first passed, Lawson evaluated changes made by the EA 2010 from the perspective of disability as they relate to the sphere of employment. ${ }^{7}$ However, neither this or any other literature specifically considers the issues facing PLHA and how these might interplay with their designation by the Act as disabled.

Additional research has been undertaken in the form of comparative studies relating to disability and the EA 2010 against the jurisdictions of France, ${ }^{8}$ Canada $^{9}$ and the provisions of the United Nations Convention on the Rights of Persons with Disabilities. ${ }^{10}$ Research has also focussed on issues including the decision to exclude addictions from the definition of disability ${ }^{11}$ and whether obesity can be classified as a disability for the purposes of the EA 2010. ${ }^{12}$ Finally, whilst the author has undertaken research examining possible implications for PLHA with

'Homosexually active men's views on criminal prosecutions for HIV transmission are related to HIV prevention need' (2008) 20 AIDS Care 509; C Dodds, A Bourne and M Weait, 'Responses to criminal prosecutions for HIV transmission among gay men with HIV in England and Wales' (2009) 17 Reproductive Health Matters 135; C Dodds and others, 'Keeping confidence: HIV and the criminal law from HIV service providers' perspectives' (2015) 25 Critical Public Health 410; E Cameron, S Burris and M Clayton, 'HIV is a virus, not a crime: ten reasons against criminal statutes and criminal prosecutions' in S Goldberg (ed), Sexuality and Equality Law (Routledge 2017).

See for example C Southam and G Howard, AIDS and Employment Law (Financial Training Publications 1988); R Watt, 'HIV Discrimination, Unfair Dismissal and Pressure to Dismiss' (1992) 21 Industrial Law Journal 280; P Wilson, 'Colleague or Viral Vector? The Legal Construction of the HIV Positive Worker' (1994) 16 Law and Policy 299; G Bindman, 'Extending Anti-Discrimination Law to AIDS and HIV' (1996) 146 New Law Journal 62; G Bindman, 'Discrimination' in I Manley and A Sherr (eds), Advising Clients with HIV and AIDS (Butterworths 2000); J Chalmers, Legal Responses to HIV and AIDS (Hart 2008).

See for example B Doyle, Equality and discrimination : the new law (Jordans 2010); B Hepple, Equality : the new legal framework (Hart 2011); M Connolly, Discrimination Law (2011 Sweet and Maxwell); J Wadham, Blackstone's guide to the Equality Act 2010 (3rd edn, Oxford University Press 2016); M Butler, Equality and anti-discrimination law : the Equality Act 2010 and other anti-discrimination protections (Spiramus Press 2016); M Sargeant, Discrimination and the Law (Routledge 2017).

A Lawson, 'Disability and Employment in the Equality Act 2010: Opportunities Seized, Lost and Generated' (2011) 40 (4) Industrial Law Journal 359.

S Corby, L William and S Richard, 'Combating disability discrimination: A comparison of France and Great Britain' (2018) European Journal of Industrial Relations 1.

P Gerber, C Batalo and E Achola, 'Dyslexia and Learning Disabilities in Canada and the UK: The Impact of its Disability Employment Laws’ (2012) 18 (3) Dyslexia 166. S Fraser Butlin, 'The UN Convention on the Rights of Persons with Disabilities: Does the Equality Act 2010 Measure up to UK International Commitments?’ (2011) 40 (4) Industrial Law Journal 428. S Flacks, 'Deviant Disabilities: The Exclusion of Drug and Alcohol Addiction from the Equality Act 2010' (2012) 21 (3) Social \& Legal Studies 395.

D Hosking, 'Fat Rights Claim Rebuffed: Kaltoft v Municipality of Billund' (2015) 44 (3) Industrial Law Journal 460; T Hervey and P Rostant, “'All About That Bass'? Is non-ideal-weight discrimination unlawful in the UK?' (2016) 79 (2) Modern Law Review 248; P McTigue, S Flint and J Snook, 'HIV/AIDS, Obesity and Stigma: A New Era for NonDiscrimination Law?' in A Sarat (ed), Studies in Law, Politics and Society (Emerald 2018). 
regard to EU disability law, ${ }^{13}$ no research evaluating whether the current framework employed by the EA 2010 is suitable in relation to HIV/AIDS exists. This work aims to address this gap in the legal literature.

This chapter will now provide a brief overview of HIV/AIDS before addressing the impact of stigma and discrimination upon PLHA. The benefits of employment to PLHA will then be identified as will barriers to PLHA entering and/or maintaining employment. Finally, the research hypothesis and structure of the work as a whole will be outlined.

\subsection{OVERVIEW OF HIV/AIDS}

In the 1980s the Acquired Immune Deficiency Syndrome ('AIDS') emerged as an epidemic after the 5 June 1981 issue of Morbidity and Mortality Weekly Report reported the deaths of five homosexual men in Los Angeles from Pneumocystis pneumonia. ${ }^{14}$ The infectious agent responsible for the disease, which later became known as the human immunodeficiency virus (HIV), was found to be transmissible by blood, certain other body fluids, sexual contact and the sharing of contaminated needles or syringes.

HIV damages the immune system, leaving the infected person vulnerable to a variety of infections (called opportunistic infections to indicate that they arise in the setting of immune impairment). The effect of HIV on the immune system is monitored by measuring an individual's CD4 count. ${ }^{15}$ CD4 cells are white blood cells that play an essential part in the human immune system. ${ }^{16}$ A normal CD4 count ranges between approximately 600 and 1,200 cells per cubic millimetre of blood and indicates that the immune system has not undergone damage that would put an individual at risk of opportunistic infections. ${ }^{17}$ Having HIV does not mean that an individual has AIDS; thus, according to the United States Centre for Disease Control and Prevention, AIDS is diagnosed when the immune system of a person infected with HIV becomes severely compromised (measured, inter alia, by a CD4 cell count of fewer than 200 cells per cubic millimetre of blood) and/or the person becomes ill with an opportunistic

P McTigue P, 'From Navas to Kaltoft: The European Court of Justice's evolving definition of disability and the implications for HIV-positive individuals' (2015) 15 (4) International Journal of Discrimination and the Law 241.

CDC, 'Pneumocystis Pneumonia - Los Angeles' (1981) 30(21) Morbidity and Mortality Weekly Report 250.

World Health Organisation, 'Consolidated guidelines on the use of antiretroviral drugs for treating and preventing HIV infection' (World Health Organisation, $2^{\text {nd }}$ edn, 2016).

Charles Bradley Hare, 'Clinical Overview of HIV Disease' (HIV Insite, 2017) <http://hivinsite.ucsf.edu/InSite?page=kb-03-01-01\#S7.2X> accessed 13 November 2017. ibid. 
infection. ${ }^{18}$ However, with early HIV diagnosis and access to effective treatment, evidence now indicates that PLHA can be expected to live into their early seventies, a life expectancy approaching that of the general population. ${ }^{19}$

Unquestionably, the greatest advance in treatment for PLHA has been the introduction of Highly Active Antiretroviral Therapy (HAART), which consists of the use of at least three antiretroviral drugs to suppress the virus and slow the progression of the disease. ${ }^{20}$ Within the employment sphere, studies have revealed that the likelihood of PLHA working decreases with disease progression. ${ }^{21}$ Yet by slowing such progression the advent of HAART has been especially effective in helping PLHA remain employed. ${ }^{22}$ In addition, decreases in workplace absenteeism have been observed to such an extent that HIV positive individuals within an employment relationship in the United States are no more likely to be absent from work due to ill health than any other employed person. ${ }^{23}$ Similar and more recent results have also been observed in South Africa. ${ }^{24}$

\subsection{STIGMA}

If the EA 2010 is to represent an adequate response to the common societal issues faced by PLHA, it is important that it adequately takes into account and combats the significant impact that stigma can play in the lives of some PLHA. Indeed, despite recent advances in treatment significantly increasing the life expectancy of PLHA and the risk of onward transmission of and Children Aged < 18 Months and for HIV Infection and AIDS Among Children Aged 18 Months to <13 Years’ (2008) 57(RR-10) Morbidity and Mortality Weekly Report 1.

J A Sterne and others, 'Long-term effectiveness of potent antiretroviral therapy in preventing AIDS and death: a prospective cohort study'(2005) 9483 The Lancet 378; Hasina Samji and others, 'Closing the Gap: Increases in Life Expectancy among Treated HIV-Positive Individuals in the United States and Canada' (2013) 8 (12) PLoS ONE < https://doi.org/10.1371/journal.pone.0081355> accessed 13 November 2017; The Antiretroviral Therapy Cohort Collaboration, 'Survival of HIV-positive patients starting antiretroviral therapy between 1996 and 2013: a collaborative analysis of cohort studies' (2017) 4 The Lancet 349.

British HIV Association, 'British HIV Association guidelines for the treatment of HIV-1-positive adults with antiretroviral therapy 2015' (2016 interim update BHIVA 2015)

<http://www.bhiva.org/documents/Guidelines/Treatment/2016/treatment-guidelines-2016-interim-update.pdf> accessed 16 November 2017.

$\mathrm{N}$ Kass and others, ' Changes in employment, insurance and income in relation to HIV status and disease progression' (1994) 7 (1) Journal of Acquired Immune Deficiency Syndromes, 86. Res. 1691

J Leigh and others, 'Absenteeism and HIV infection' (1997) 4 (5) Applied Economics Letters 275. 
HIV ${ }^{25}$ stigma and discrimination continue to impact negatively on the quality of life for PLHA. ${ }^{26}$ In a nationally representative survey of PLHA undertaken in England and Wales in 2017 , of 4,424 participants, one in eight people said they had not told anyone, other than healthcare professionals, about their HIV status. This underlines the necessity for the legal framework employed by the EA 2010 to combat stigma and discrimination directed towards PLHA.

Erving Goffman developed a seminal definition of stigma based on his work in psychiatric hospitals and among criminals and homosexuals. ${ }^{27}$ He defined stigma as 'an attribute that is deeply discrediting' and one which reduces the individual concerned 'from a whole and usual person to a tainted, discounted one'. ${ }^{28}$ In addition, he theorised that society stigmatises those who are different or, in his words, deviant and that such stigma results in a spoiled identity for the individual with the discrediting attribute.

In her pivotal 1989 work, AIDS and Its Metaphors, Sontag asserted that the fear associated with HIV/AIDS is significantly greater than other conditions because of its interaction with three distinct phenomena, namely HIV/AID's association with unacceptable practices, ${ }^{29}$ the complete lack of any successful treatment to completely eradicate the virus from the human body, ${ }^{30}$ and society's misjudged opinion regarding self-infliction. ${ }^{31}$ HIV/AIDS is associated with unacceptable social practices ${ }^{32}$ and with sex, which has led to it being regarded by many as associated with excess. ${ }^{33}$ Unfortunately for PLHA the idea that they are being punished for their behaviour is deeply ingrained into society's construction of HIV. ${ }^{34}$ Within the popular

British HIV Association ' $\mathrm{U}=\mathrm{U}$ consensus statement: Risk of sexual transmission of HIV from a person living with HIV who has an undetectable viral load' (Prevention Access Campaign, 23 August 2018) <www.preventionaccess.org/consensus.> accessed 6 December 2018.

Public Health England, 'Progress towards ending the HIV epidemic in the United Kingdom: 2018 report' (Public Health England 2018), 36.

Erving Goffman, Stigma notes on the management of spoiled identity (Penguin 1963).

ibid, 3 .

Simon Watney, Practices of freedom: Selected writings on HIV/AIDS (Duke University Press 1994).

T Stoddard, 'Don't call it AIDS' New York Times (New York, 17 August 1994) 15; Moji Anderson and others, 'HIV/AIDS-related stigma and discrimination: Accounts of HIV-positive Caribbean people in the United Kingdom' (2008) 67 (5) Social Science \& Medicine 790; P Hutchinson and R Dhairyawan, 'Shame, stigma, HIV: philosophical reflections' (2017) Medical Humanities 1.

G Herek and J Capitanio, 'AIDS Sigma and Sexual Prejudice' (1999) 42 (7). American Behavioural Scientist 1130; G Herek, 'AIDS and Stigma' (1999) 42 (7) American Behavioural Scientist 1106; Jane Northrop, 'A dirty little secret: stigma, shame and hepatitis C in the health setting' (2017) 43 Medical Humanities 218.

Susan Sontag,, AIDS and Its Metaphors (Penguin 1989).

$\mathrm{H}$ Liu and others, 'Relation of sexual risks and prevention practices with individuals' stigmatising beliefs towards HIV infected individuals: an exploratory study’ (2005) 81 Sexually Transmitted Infections 511; P Boyce and others, 'Putting sexuality (back) into HIV/AIDS: Issues, theory and practice' (2007) 2 (1) Global Public Health 1.

Loretta M. Kopelman, 'If HIV/AIDS is Punishment, Who is Bad?' (2002) 27 (2) Journal of Medicine and Philosophy 231. 
imagination the unsafe behaviour associated with HIV is various ${ }^{35}$ including injecting drug use, sex amongst MSM and/or promiscuity. ${ }^{36}$ This fear and negative perception of PLHA contributes to considerable stigma towards the virus. The continuing relevance of Sontag's work to the issue of the stigma associated with HIV is illustrated by the responses received from participants to the empirical research undertaken, as seen in section 6.2.2.

In essence two main theories assist in explaining the unique levels of discrimination and stigma directed towards some PLHA. The first relates to the marginalised nature of the vast majority of PLHA, e.g. their status as Injecting Drug Users, MSM or members of ethnic minorities. Thus, a number of commentators advance the idea that discrimination against PLHA is often related to pre-existing stigma, which makes PLHA particularly vulnerable to discrimination. ${ }^{37}$ The second centres upon the characteristics of the virus itself, with significant focus placed on the fact that it is currently a potentially fatal infectious disease with no cure. ${ }^{38}$

Even with recent advances in HIV medication, stigma continues to impact significantly upon the lives of some PLHA. It often results in discrimination, exclusion, and disempowerment. ${ }^{39}$ This in turn may lead people with HIV to self-stigmatise and experience social isolation. ${ }^{40}$ Studies have linked HIV-related stigma with a refusal to undertake HIV testing, ${ }^{41}$ nondisclosure of viral status to partners ${ }^{42}$ and poor adherence to HIV medication. ${ }^{43}$ Such stigma

Anish P. Mahajan and others, 'Stigma in the HIV/AIDS epidemic: A review of the literature and recommendations for the way forward' (2008) 22 AIDS S67.

G Herek, J Capitanio and K Widaman, 'HIV-related stigma and knowledge in the United States: prevalence and trends 1991-1999' (2002) 92 (3) American Journal of Public Health 371.

G Herek, J Capitanio and K Widaman, 'HIV-related stigma and knowledge in the United States: prevalence and trends 1991-1999' (2002) 92 (3) American Journal of Public Health 371; D Studdert, 'Charges of Human Immunodeficiency Virus Discrimination in the Workplace: The Americans with Disabilities Act in Action' (2002) 156 (3) American Journal of Epidemiology 219.

L Conyers, K Boomer and B McMahon, 'Workplace discrimination and HIV/AIDS: The national EEOC ADA research project' (2005) 25 (1) Work 37.

N Gilmore and M Somerville, 'Stigmatization, scapegoating and discrimination in sexually transmitted disease: Overcoming the "them" and "us" (1994) 39 (9) Social Science and Medicine 1339.

M Longo, J Sprose and A Locke, 'Identifying major concerns of persons with acquired immunodeficiency syndrome' (1990) 4 Clinical Nurse Specialist 21; R Barrett, 'Elephant people: The phenomena of social withdrawal and selfimposed isolation of people dying with AIDS' (1995) 9 AIDS Patient Care 240; Charles A. Emlet, 'An Examination of the Social Networks and Social Isolation in Older and Younger Adults Living with HIV/AIDS' (2006) 31 (4) Health \& Social Work 299; Julie A. Cederbaum and others, 'Social networks of HIV-positive women and their association with social support and depression symptoms’ (2017) 57 (2) Women \& Health 268.

JM Turan and others, ' HIV/AIDS stigma and refusal of HIV testing among pregnant women in rural Kenya: results from the MAMAS study’ (2011) 15 (6) AIDS Behaviour 1111.

H Brou and others, 'When do HIV-infected women disclose their HIV status to their male partner and why?' (2007) 4 (12) PLoS Med 342.

N C Ware, M A Wyatt and T Tugenberg, 'Social relationships, stigma and adherence to antiretroviral therapy for HIV/AIDS’ (2006) 18 (8) AIDS Care 904. 
often results in discrimination. ${ }^{44}$ The recent People Living with HIV Stigma Survey recruited 1576 participants from community organisations and HIV clinics throughout the UK. ${ }^{46}$ Approximately half of the participants reported feeling shame, guilt, low self-esteem and/or self-blame in relation to their HIV status. ${ }^{47}$ In addition, $18 \%$ of participants overall reported suicidal ideation, whilst for those diagnosed in the last 12 months the figure rose to $28 \%{ }^{48}$ However, the ability for PLHA to enter and/or maintain employment can be a useful tool to combat these negative consequences which is why the EA 2010, and the manner in which it protects PLHA, needs to reflect accurately the issues affecting PLHA, comply with relevant external legal obligations and provide PLHA with an effective legal framework against discrimination.

\section{$1.4 \quad$ EMPLOYMENT}

The EA 2010 makes it unlawful to discriminate against, harass or victimise a person within employment. ${ }^{49}$ It is therefore imperative that the current framework employed by the EA 2010 represents an adequate response to the issues faced by PLHA and ensures that they are adequately protected from discrimination within employment. The benefits of employment to PLHA are well documented. Employment is directly associated with improved psychological and psychosocial functioning for PLHA as demonstrated by research in Blalock and others. ${ }^{50}$

From a sociological perspective, whilst there has been significant research into HIV and AIDS, little research has been conducted into the specific issue of PLHA within an employment relationship. Indeed, with the exception of Douglas's study into the employment experiences of MSM and black African men and women living with HIV in the UK, no empirical research has been undertaken into this issue within the UK. ${ }^{51}$ This work aims to remedy that situation.

Employment provides a source of purpose for people with health conditions and also allows individuals with chronic or life-threatening diseases to maintain their income and purchase the Anne L Stangl and others, 'A systematic review of interventions to reduce HIV-related stigma and discrimination from 2002 to 2013: how far have we come?' (2013) 16 (3) J Int AIDS Soc 18734. The People Living with HIV Stigma Survey UK, 'HIV in the UK: Changes and Challenges; Actions and Answers - The People Living With HIV Stigma Survey UK 2015 (The People Living with HIV Stigma Survey UK 2015) <http://www.stigmaindexuk.org/reports/2016/NationalReport.pdf> accessed 16 November 2017. ibid, 8 .

ibid, 8 .

Part 5 of the EA 2010.

A Blalock, J McDaniel and E Farber, 'Effect of employment on quality of life and psychological functioning in patients with HIV/AIDS’ (2002) 43 (5) Psychosomatics 400.

$51 \quad$ N Douglas, 'I just get on with it...A study of the employment experiences of gay and bisexual men and black African men and women living with HIV in the UK' (Terrence Higgins Trust 2009).
} 
basic materials essential for survival. ${ }^{52}$ However, even in the era of HAART, barriers remain which prevent some PLHA finding, maintaining or returning to employment. Persistent high unemployment rates have been reported amongst PLHA. ${ }^{53}$ In France, Annequin and others found that PLHA's unemployment rate was 1.62 times higher than that of the general population in $2011 .^{54}$ Later research undertaken by Annequin and others in this area found that improvements in HIV care occurred in the era of HAART have not translated into improvements in all PLHA's situation regarding employment. ${ }^{55}$ However, persistently high rates of unemployment amongst PLHA may reflect sociodemographic disadvantages linked to lower workforce participation (i.e. female gender, advanced age, low educational level, manual occupational, foreign national status, injection drug use) which existed prior to HIV infection. ${ }^{56}$ Thus, among highly educated individuals diagnosed with HIV from 1994 onwards, employment rates appear to be comparable to that of the general population, suggesting that since the introduction of HAART HIV infection does not appear to impair employment amongst socially privileged individuals. ${ }^{57}$

For those PLHA within an employment relationship the issue of disclosure often presents challenging questions and decisions. Dray-Spira et al. reported that $70.1 \%$ of respondents in their 2007 French study had not disclosed their HIV status to their employer or colleagues. ${ }^{58}$ More recently in Belgium in 2014 half of the 54 participants in the research undertaken by Degroote and others did not disclose their HIV status in the workplace, mainly due to fear of social or professional consequences. ${ }^{59}$ In the UK the People Living with HIV Stigma Survey illness control' (1996) 41 (3) Rehabilitation Psychology 205; C Worthington and H Krentz,,'Socio-economic factors and health-related quality of life in adults living with HIV.' (2005) 16 (9) Int J STD AIDS 608-614; R Dray-Spira and others, 'Temporary employment, absence of stable partnership, and risk of hospitalization or death during the course of HIV infection' (2005) 40 (2) J Acquir Immune Defic Syndr. 190; D Blustein and others, 'Lessons in survival: forging an experience-near understanding of the interface of work and health' (2008) 36 (1) Counselling 90. R Burgoyne and D Saunders, 'Perceived support in newly registered HIV/AIDS clinic outpatients' (2000) 12 (5) AIDS Care 643; R Dray-Spira and others, 'Socio-economic conditions, health status and employment among persons living with HIV/AIDS in France in 2001' (2003) 15 AIDS Care 739; C Worthington and H Krentz,, 'Socio-economic factors and health-related quality of life in adults living with HIV.’ (2005) 16 (9) Int J STD AIDS 608. HIV and the French General Population' (2016) PLoS ONE 11(11)<https://doi.org/10.1371/journal.pone.0165634> accessed 14 May 2018. AIDS 1537.

R Dray-Spira and others, 'Socioeconomic differences in the impact of HIV infection on workforce participation in France in the era of Highly Active Antiretroviral Therapy' (2007) 97 (3) American Journal of Public Health 552. ibid

R Dray-Spira and others, 'Socioeconomic differences in the impact of HIV infection on workforce participation in France in the era of Highly Active Antiretroviral Therapy' (2007) 97 (3) American Journal of Public Health 552. 
reported in 2015 that approximately half $(47 \%)$ of the 1,059 participants currently working reported that someone in their workplace was aware of their HIV status. ${ }^{60}$ Fesko reviewed the workplace experiences and disclosure decisions of 18 PLHA. ${ }^{61}$ She discovered that 6 of the 18 participants were completely open about their HIV status within the workplace. ${ }^{62} 7$ individuals had revealed their status to selected people in the workplace and, at the point of doing so, requested that the information be kept confidential. ${ }^{63}$ Finally, 5 individuals reported that they did not tell anyone in their workplace. ${ }^{64}$ Individuals identified the stigma associated with HIV as being a factor in their decision to disclose and some felt that they might disclose in future if the stigma associated with the disease were reduced. ${ }^{65}$ In addition, participants also described multiple levels of stigma associated with homosexual orientation or membership of an ethnic minority group. ${ }^{66}$

Douglas conducted research into the employment experiences of MSM and black African men and women living with HIV in the UK. ${ }^{67}$ The research employed both qualitative forms of inquiry, in the form of 5 focus group sessions with 38 participants, and quantitative forms of inquiry, in the form of an online survey of men using the gay social networking website Gaydar. A total of 8,369 eligible respondents completed this online questionnaire. Douglas discovered that $40 \%$ of relevant respondents had disclosed their HIV status to their supervisor or manager at work. Working for a large employer (500 plus employees) was not significant but, those who were taking HAART in working hours and perceived that their body showed some physical sign of living with HIV were more likely to have disclosed. Those working in the private sector were less likely to have disclosed. The most commonly cited reasons for non-disclosure were that being HIV positive did not affect the respondent's work, concerns concerning breaches of confidentiality and fears that poor treatment at work would follow. It was also discovered that if MSM and black Africans were to experience discrimination at work, this would more likely be for reasons of their more visible identities as gay or bisexual men or black people. Thus, as one respondent noted, HIV added an extra layer of disadvantage to her life: S Fesko, 'Disclosure of HIV status in the workplace: considerations and strategies' (2001) 26 (4) Health \& Social Work 235. ibid, 238. ibid.

ibid. ibid, 240. ibid. N. Douglas, 'I just get on with it...A study of the employment experiences of gay and bisexual men and black African men and women living with HIV in the UK' (National AIDS Trust 2009).
} 
Being from an ethnic background, being black, is one thing; being from [an] ethnic background and can't communicate, that's another thing. Being from an ethnic minority and being black and having HIV, that's another problem. ${ }^{68}$

This finding is also supported by research undertaken by Elford and others who questioned 1,687 PLHA in London between 2004 and 2005 and discovered that whilst 30.5\% of white gay men had disclosed their HIV status to their employer, only $8.8 \%$ of black African heterosexual men had. ${ }^{69}$

\subsection{RESEARCH HYPOTHESIS AND STRUCTURE}

Given the persistently high levels of stigma associated with HIV despite the presence of the EA 2010, this research is based on the hypothesis that the manner in which PLHA are protected from discrimination in the UK is inadequate. This is in part due to the Act's failure to adequately take into account the concerns of PLHA; therefore this work includes an empirical element and draws upon the 'nothing about us without us' principle which expresses that persons with disabilities know what is best for them and their community. ${ }^{70}$ From a legal perspective it will build upon the rights propounded in the United Nations Convention on the Rights of Persons with Disabilities, which as Broderick notes, 'recognises the fact that persons with disabilities are holders of rights on an equal basis with others and that they are not objects of charity. ${ }^{71}$

To examine whether the current framework employed by the EA 2010 represents an adequate response to the issues faced by PLHA and is consistent with international and European legal obligations, the chapters of this thesis have been organised around an examination of both the legal framework relating to the protection of PLHA from discrimination and the experiences of PLHA themselves. The thesis consists of eight chapters, including the introduction.

Having outlined the key themes of the thesis, the research hypothesis and the research question in this introductory chapter, Chapter 2 entitled 'Methodology' provides a discussion of the methods employed in the undertaking of this research. This work employed both empirical and doctrinal research and the choice and role of both will be discussed, as will the interaction and role played by both in answering the research questions.

Chapter 3 entitled 'The International and European Legal Framework relating to HIV/AIDS' provides the relevant rules and principles of international and European law related to PLHA. The identification of the relevant rules and principles of international and European law allows

ibid, 31

Jonathan Elford and others, 'Disclosure of HIV status - The role of ethnicity among people living with HIV in London, (2008) 47 Journal of AIDS 514.

James Charlton, Nothing About Us Without Us (University of California Press 2000).

A Broderick, The long and winding road to equality and inclusion for persons with disabilities: The United Nations

Convention on the Rights of Persons with Disabilities (Intersentia 2015), 79. 
for consideration to be made later in the thesis regarding the extent to which the EA 2010 accords with relevant international and European legal obligations. The manner in which PLHA are afforded protection under international and European legal instruments is identified in this Chapter in addition to the range of conduct prohibited against PLHA.

Chapter 4 entitled 'The Domestic Legal Framework relating to HIV/AIDS' provides discussion and analysis of the EA 2010 and determines the manner in which PLHA are protected by law at the domestic level. It does this in order to analyse the extent to which the EA 2010 is compliant with relevant international and European obligations and illustrates that the manner in which PLHA are protected by the EA 2010 differs markedly from the approach taken at both the international and European level.

Chapter 5 entitled 'HIV as a Disability' examines the background to and reasons for the decision to afford PLHA with protection on the ground of disability. ${ }^{72}$ The deeming of HIV as a disability was made by the Disability Discrimination Act 2005, and the chapter identifies the reasons why the UK has taken a different approach to protecting PLHA to that taken by both international and European law. It does this by analysis of both the consultation exercise undertaken by the Government in respect of the proposed change and the passage of the Disability Discrimination Act 2005 through Parliament.

Chapter 6 entitled 'Empirical Findings - Sociological Themes' and Chapter 7 entitled 'Empirical Findings - Legal Themes' present the findings of the empirical research undertaken and employ those findings in order to determine whether the designation of HIV as a disability by the Equality Act 2010 represents an adequate response to the issues faced by PLHA. Chapter 6 focuses primarily on PLHA's experiences of stigma, discrimination and disclosure of their HIV status to employers. Chapter 7 then focuses primarily on PLHA's awareness of the EA 2010 and their thoughts on the decision taken by the EA 2010 to deem them as disabled.

Chapter 8 entitled 'Conclusions' contains the outcome of this research and a summary of the answers to the research questions. It also contains recommendations for amendments to the EA 2010 to ensure that it better accords with the wishes of PLHA whilst ensuring the UK's compliance with international and European legal obligations. The original contribution that this work makes to existing legal scholarship is also identified. 


\section{CHAPTER 2: METHODOLOGY}

\section{$2.1 \quad$ INTRODUCTION}

The need for research into the issues facing People living with HIV or with AIDS (PLHA) with regard to participation in employment and non-discrimination was highlighted in Chapter 1 . To reiterate, the objective of the research is to explore and critically evaluate the extent to which the Equality Act 2010 (EA 2010) protects PLHA within an employment relationship from discrimination. More specifically, it seeks to identify whether the current legal framework, which deems all PLHA to be disabled, ${ }^{73}$ both represents an adequate response to the issues faced by PLHA and is consistent with international and European legal obligations. It also seeks to offer recommendations as how to refine legal protection for PLHA in this area in order to ensure that the UK's approach accords with both the experiences and wishes of PLHA, and the UK's legal obligations. The chapter will outline the methodology employed in order to meet those objectives.

The chapter will start by highlighting to the reader the author's philosophical perspective in the undertaking of this research before addressing his prior and personal knowledge of the research area. The design of the research methodology will then be outlined. For this piece of work both empirical and doctrinal research was employed. Thus, the choice and role of both the doctrinal research and the empirical research will be addressed in turn. It will also be made clear how the doctrinal and empirical research undertaken correspond and interact with one another both in analysing the relevant sources and answering the research questions.

\subsection{PHILOSOPHICAL PERSPECTIVE}

Ontology is a set of assumptions about what the world is or what we believe it is possible to know about the world. When undertaking the research, the author's perspective adhered to what Hammersley terms subtle realism. ${ }^{74}$ The manifestation of this is that the social world exists independently of individual subjective understanding; however, it is only accessible via the human mind and socially constructed meanings. Thus, in this piece of work the social world, including the law, is only accessible via individuals' interpretations and reactions. By way of example, when undertaking empirical research, the participants' own interpretations of the relevant research issues and the importance they attach to the same are critical. Their responses are diverse reflecting their different vantage points and different types of understanding. However, these differing perspectives reflect the various distinct ways in which external reality 
is experienced by individuals. Subtle realism also played a part when undertaking the doctrinal research because as Van Hoecke notes, "there is no "objective" reality outside the constructions of legal doctrine', indeed 'legal scholars very regularly take normative positions; posit some choice among values or interests, which is 'subjective' par excellence. ${ }^{75}$

Epistemology is concerned with what constitutes knowledge and how it can be acquired. The author's perspective adhered to the interpretivist position; thus, if we are to understand and explain human behaviour we need to understand the meanings and interpretations that individuals attach to phenomena in the social world. ${ }^{76}$ Consequently, the research adopted a naturalistic, interpretative approach and attempted to understand the meanings which PLHA attach to phenomena within their social worlds. ${ }^{77}$ This acknowledges that all knowledge is contextual and situational, indeed Cain has used the term 'historical specificity' in order to describe the situational nature of knowledge which includes an emphasis on the historical and constantly changing nature of human relationships and understanding. ${ }^{78}$

\section{$2.3 \quad$ TRANSPARENCY}

By employing the interpretivist approach, it was acknowledged by the author that there was the possible of potential impact upon the social world in which the research was undertaken. Thus, as Ritchie and Lewis note, facts and values are not distinct and any findings made are inevitably influenced by a researcher's own outlook and values. ${ }^{79}$ The research was thus shaped by my own experiences and, inevitably to some extent, the research findings represent my personal position. Indeed, my interpretation of relevant normative legal sources was also influenced by my personal position. To counter this, the process of reflexivity was employed at all stages of the research process. This was a conscious decision and an acknowledgement of the fact that the author's own personal experiences and background may be relevant to their qualitative research practice, for example in their relationships with participants or the interpretation and analysis of data. Shacklock and Smyth assert that reflexivity is an attempt to identify, act upon and acknowledge the limitations of any research undertaken, i.e. its subjects, its process, its Mark Van Hoecke, 'Legal Doctrine: Which Method(s) for What Kind of Discipline?' in Mark Van Hoecke (ed), Methodologies of Legal Research : Which Kind of Method for What Kind of Discipline? (Hart 2011), 18 (emphasis in original).

76 M Williams and T May, Introduction to the philosophy of social research (UCL Press 1996); M Crotty, The Foundation of Social Research: Meaning and Perspectives in the Research Process (Sage 1998); G Letherby, J Scott and M Williams, Objectivity and subjectivity in social research (Sage 2013).

77 A Bryman, Social Research Methods (5th edn, Oxford University Press 2015); J Ritchie and J Lewis, Qualitative Research Practice (Sage 2013).

78 M Cain,'Realist Philosophy and Standpoint Epistemologies of Feminist Criminology as a Successor Science' in L Gelsthorpe, and A Morris (eds) Feminist Perspectives in Criminology (Open University Press 1990). 
theoretical context, its data, its analysis and how accounts recognise that the construction of knowledge takes place in the world and not apart from it. ${ }^{80}$ In order to be reflexive, a research diary was kept in which reflections on the author's emotional state whilst undertaking the research were made as well as any thoughts and observations. During the writing up process, this diary was referred to in order to attempt to minimise any extremes in emotional state influencing the interpretation and analysis of the data. In addition, all interviews undertaken were audio recorded and at the analysis stage, each one was listened to multiple times when analysing the interview transcript. This was in order to attempt to ascertain any bias, whether positive or negative, that the author may have held with regard to any of the research participants which could have affected the interpretation of the data.

Being reflexive is, "part of being honest and ethically mature in research practice that requires researchers to stop being shamans of objectivity. ${ }^{81}$ Not to acknowledge the interests implicit in a critical agenda for the research or to assume value-free positions of neutrality is to assume 'an obscene and dishonest position. ${ }^{, 82}$ With this in mind, it is only right and proper that the reader is aware of the author's personal perspective and experience. As the remainder of this section is at times inherently personal, the use of the first person will be employed in an attempt to minimise barriers between the author and the reader.

I was born in 1975 and soon after birth diagnosed with Haemophilia A. ${ }^{83}$ This is a bleeding disorder caused by a deficiency of a protein, Factor VIII, which is essential for the normal clotting of blood. ${ }^{84}$ As a result of this, even relatively minor injuries may lead to prolonged bleeding. Bleeding into joints is common, leading to severe pain and eventually to permanent damage to the joint. Such bleeding may also occur spontaneously. Haemophilia can seriously diminish one's quality of life. Prior to the availability of effective treatment, the condition caused episodic crises requiring urgent medical treatment, in addition to a restriction of schooling, employment capacity and the ability to travel. ${ }^{85}$ It also reduced life expectancy, particularly by reason of bleeding into the brain or gastro-intestinal tract. ${ }^{86}$

Haemophilia is a hereditary condition and confined almost exclusively to males. It is, however, transmitted through the female line. This means that women can carry the gene for haemophilia

G Shacklock and J Smyth, Being Reflexive in Critical Educational and Social Research (Falmer 2008).

J Ruby, 'Exposing yourself: Reflexivity, anthropology, and film' 30 1/2 Semiotica 153, 154.

G Shacklock and J Smyth, Being Reflexive in Critical Educational and Social Research (Falmer 2008), 6.

For more detail on haemophilia, in particular from a treatment perspective, see P Mannucci, 'Back to the future: a

recent history of haemophilia treatment' 200814 (3) Haemophilia 10

Haemophilia Society, 'Understanding haemophilia' (Haemophilia Scoiety 2017).

P Mannucci, 'Back to the future: a recent history of haemophilia treatment' 200814 (3) Haemophilia 10.

Lord Archer of Sandwell, N Jones and J Willetts, 'Independent Public Inquiry Report On NHS Supplied

Contaminated Blood and Blood Products' (Archer Inquiry 2009)

<http://www.archercbbp.com/files/report/76_Lord\%20Archer\%20Report.DOC> accessed 1 December 2017. 
without suffering the symptoms. Any son of such a carrier would have a one in two chance of inheriting the condition from them, and their daughters would have a one in two chance of also becoming a carrier. A man with haemophilia cannot pass it on to his sons but will inevitably pass it to his daughters who will become carriers. ${ }^{87}$ By way of example, my maternal grandfather was a haemophiliac. He fathered three daughters and all were carriers of haemophilia. When all later married and had children of their own, there was a haemophiliac son in each of these three branches of the family.

Before 1965, there was no known effective treatment for haemophilia, and until the 1940s treatment usually consisted of bed rest and cold compresses. ${ }^{88}$ Episodes involving severe loss of blood could be compensated by blood transfusions, but these were not a form of treatment for the condition itself. However, in 1965 a group of researchers at Stanford University discovered that by freezing plasma and then thawing it slowly, they could produce a residue rich in Factor VIII known as cryoprecipitate. ${ }^{89}$ It had ten times the concentration of the Factor VIII produced naturally by the body but, it could take a long time to thaw and was not easy to transport on long journeys. ${ }^{90}$

Afterwards in the late 1960s it was discovered that if cryoprecipitate was dissolved, treated chemically and subjected to a centrifugal process, it produced a crystalline powder which had ten times the clotting power of cryoprecipitate and when dissolved in sterile water could be injected at home. ${ }^{91}$ This became known as Factor VIII concentrate. The disadvantage was that to be processed economically it required a substantial amount of plasma, pooled from a large number of donors. It can take up to 30,000 donations of blood to make one batch of factor concentrate and blood products have always been susceptible to contamination by viruses. ${ }^{92}$ This pooling of donors substantially increases the risk of transmission of infection from any one donor.

From the early 1970s, Factors VIII became readily available in concentrated form. It could be stored in domestic refrigerators, carried conveniently on journeys and injected when and where required. This represented a significant advance in the quality of life for patients and there was

Haemophilia Society, 'Understanding haemophilia' (Haemophilia Scoiety 2017).

P Mannucci, 'Back to the future: a recent history of haemophilia treatment' 200814 (3) Haemophilia 10.

Lord Archer of Sandwell, N Jones and J Willetts, 'Independent Public Inquiry Report On NHS Supplied

Contaminated Blood and Blood Products' (Archer Inquiry 2009)

<http://www.archercbbp.com/files/report/76_Lord\%20Archer\%20Report.DOC> accessed 1 December 2017.

ibid.

P Mannucci, 'Back to the future: a recent history of haemophilia treatment' 200814 (3) Haemophilia 10.

NAM Aidsmap, 'Haemophilia and HIV' (NAM Aidsmap 1 October 2009) < http://www.aidsmap.com/Blood-

products-and-haemophilia/page/1324537/ > accessed 8 May 2018. 
promise of a new dawn for haemophiliacs. ${ }^{93}$ However, in 1981 as a result of treatment by contaminated Factor VIII a haemophiliac in the United States of America died from what is now termed an AIDS-related illness. Despite this fact, the association between factor concentrates, AIDS and viral contamination was not made until 1983. ${ }^{94}$ The consequence of this is that large numbers of the haemophiliac community continued to use contaminated factor concentrates, often sourced from high-risk donors, for some considerable time. It was only when the test for HIV was pioneered and people with haemophilia were routinely tested that the proliferation of HIV amongst the haemophiliac community became apparent. In the United Kingdom of the 7,250 people with haemophilia 1,246 had become infected with HIV. ${ }^{95}$ Members of my family and significant numbers of my friends were included in that number. ${ }^{96}$

The above events all shaped me as a person and also enabled me to use my personal knowledge and expertise of HIV for the benefit of the research. I felt I had a degree of familiarity with PLHA and could empathise with them. I was also comfortable with the terminology and acronyms ${ }^{97}$ that participants might use in their interviews which placed me in a favourable position and allowed me to interact more easily and gain a better understanding of individuals' perspectives. I was also aware that I would need to be careful as to how I constructed the concept of disability in relation to PLHA as all the HIV positive haemophiliacs I knew considered themselves disabled. Often, however, this was as a result of the severe damage to their joints caused by internal bleeding episodes as opposed to their HIV status. This is an issue that clearly does not affect the majority of PLHA and indeed did not affect the majority of my participants.

\subsection{DOCTRINAL METHODOLOGY}

In order to identify the extent to which the EA 2010 protects PLHA within employment from discrimination, I began with a doctrinal methodology. Doctrinal research is 'concerned with the formulation of legal "doctrines" through the analysis of legal rules"98 and has been defined as,

Lord Archer of Sandwell, N Jones and J Willetts, 'Independent Public Inquiry Report On NHS Supplied

Contaminated Blood and Blood Products' (Archer Inquiry 2009)

<http://www.archercbbp.com/files/report/76_Lord\%20Archer\%20Report.DOC> accessed 1 December 2017, 13. ibid.

S Darby and others, 'The impact of HIV on mortality rates in the complete UK haemophilia population' (2004) 18 (3) AIDS, 18(3) 525.

Once blood products were heat-treated, the haemophilia community effectively ceased to be at risk of HIV infection from their treatment. Those with haemophilia and HIV are therefore a finite group of people. After mid-1985, at the very latest, no person should have been infected with HIV in the UK through the use of factor concentrates. See Farrell, A., 2012. The Politics of Blood, Cambridge: Cambridge University Press, for an illuminating account of this episode.

For example viral load counts, CD4 counts. These concepts will be discussed in greater detail later in the work. Paul Chynoweth, 'Legal research' in Andrew Knight and Les Ruddock (eds), Advanced Research Methods in the Built Environment (Blackwell 2008), 29. 
'a detailed and highly technical commentary upon, and systematic exposition of, the context of legal doctrine'. ${ }^{99}$ It is aimed at 'parsing the law from the density of rules, legislation, case law and possibly scholarly materials that may apply to a particular issue being examined.' ${ }^{100}$

This first stage of research involved the collection of all relevant material. This was in effect a two stage process involving first the collection of what Van Hoecke identifies as "normative sources, such as statutory texts, treaties, general principles of law, customary law, binding precedents, and the like' and second, the collection of 'authoritative sources, such as case law, if they are not binding precedents, and scholarly legal writings.' ${ }^{101}$ Although primarily concerned with the relevant domestic legislation in this area, ${ }^{102}$ the research also involved a consideration of the issue from an international and European perspective, due as a consequence of the UK possessing what Bamforth and Leyland term a 'multi-layered constitution' . 103

The main research question of this thesis is effectively 'whether the designation of HIV as a disability by the EA 2010 represents an adequate response to the issues faced by PLHA and is consistent with international and European legal obligations.' In order to fully answer that question, the doctrinal research sought to answer the following three subsidiary research questions:

1. In what precise manner did the relevant normative sources afford protection to PLHA? By way of example, were PLHA protected on the basis of a general antidiscrimination framework grounded in notions of equality and dignity for all individuals, or by manner of a more specific prohibition linked perhaps to health status or actual or perceived disability?

2. What conduct against PLHA was prohibited by each individual normative source? By way of example, was protection offered on the grounds of say direct or indirect discrimination? Alternatively, did the relevant normative source afford PLHA with access to reasonable accommodations? ${ }^{104}$

3. Did legal protection of PLHA by the EA 2010 comply with the requirements of relevant international and European normative sources identified? Research (Pearson 2007), 31. Law, Criminology \& Socio-Legal Studies Research Paper No. 19/17 <https://ssrn.com/abstract=3082194> accessed 18 September 2018. 
These subsidiary research questions are answered in Chapters 3 and 4. Thus, Chapter 3 examines international and European normative sources relating to PLHA and identifies the precise manner in which PLHA are protected from discrimination and what conduct against PLHA is prohibited. Chapter 4 then repeats this process but from a domestic perspective, i.e. it examines domestic normative sources relating to PLHA, identifies the precise manner in which PLHA are protected at the domestic level and what conduct is prohibited.

Yet normative sources do not exist in isolation from the social world and, in a similar vein to the ontological standpoint employed by this work, Bradney argues that 'doctrinal work has always been infused with intellectual presumptions and assumptions that have dominated the doctrinal argument even though the doctrinal argument has concealed their existence.' ${ }^{105}$ Consequently in order to interpret normative sources, doctrinal analysis 'usually makes at least some reference to other, external, factors as well as seeking answers that are consistent with the existing body of rules.' 106 Thus once it became apparent that PLHA are deemed to be disabled for the purposes of the EA 2010, research was undertaken to examine the historical development of the protection afforded to PLHA by the UK Parliament and ascertain the rationale for protecting PLHA from discrimination in this manner. ${ }^{107}$ To do this, research and analysis of the consultation exercise carried out by the Government in respect of the decision to deem HIV a disability was undertaken. In order to obtain copies of responses to the consultation exercise, Freedom of Information requests were submitted to Her Majesty's Government Office for Disability Issues. In addition, research was also undertaken into the passage of the relevant legislation through Parliament, which involved analysis and interpretation of Hansard, the official record of Parliamentary proceedings. This additional research was considered necessary as an unclear normative source 'can often be more easily interpreted when viewed in its proper historical or social context, or when the interpreter has an adequate understanding of the industry or technology to which it relates.' 108

\subsection{EMPIRICAL METHODOLGY}

A purely doctrinal approach to legal research would do little to assist in ascertaining PLHA's experiences of discrimination in employment. It would also be unable to document the thoughts and opinions of PLHA in relation to being deemed to be disabled by the EA 2010 regarding whether the Act represents an adequate response to the issues faced by PLHA. To approach 
these issues, empirical research was undertaken because as Bradney remarks, 'empirical research into law and legal processes provides not just more information about law; it provides information of a different character from that which can be obtained through other methods of research. It answers questions about law that cannot be answered in any other way.' 109

The information obtained from the doctrinal research undertaken was, however, key in informing the empirical methodology of this thesis, which in turn informed Chapters 6 and 7. Literature associated with the relevant normative legal sources also assisted this process. By way of example, participants were asked whether they were aware that PLHA were protected from discrimination under the EA 2010 and if so, whether they were aware such protection was on the basis that PLHA were deemed to be disabled. Their opinions as to being labelled in this manner were sought, as were their thoughts as to whether such a designation would make them more likely to disclose their HIV status to employers in the future.

The doctrinal research also illustrated the important role that reasonable adjustments play in ensuring effective participation in the workplace by individuals with disabilities. With that in mind questions were formulated that involved asking participants whether they aware of the concept of reasonable adjustments and whether they had requested any from their employer. They were also questioned as to their thoughts on whether they would feel comfortable disclosing their HIV status in order to request reasonable adjustments.

The methodology for the empirical research was also shaped by the initial review of non-legal research detailed in Chapter 1. This review discovered that, with the exception of work by Douglas, there was no existing empirical research into discrimination against PLHA within employment in the UK. ${ }^{110}$ The review also discovered that stigma and discrimination against PLHA continue to be of concern. ${ }^{111}$ However, much of the literature concerning stigma and

Anthony Bradney, 'The Place of Empirical Legal Research in the Law School Curriculum' in Peter Cane and Herbert Kritzer (eds), The Oxford Handbook of Empirical Legal Research (OUP 2010), 1033 men and women living with HIV in the UK' (Terence Higgins Trust 2009).

111 Simon Watney, Practices of freedom: Selected writings on HIV/AIDS (Duke University Press 1994); T Stoddard, 'Don't call it AIDS' New York Times (New York, 17 August 1994) 15; A Alonzo and N Reynolds, 'Stigma, HIV and AIDS: An exploration and elaboration of a stigma trajectory’ (1995) 41 (3) Social Science \& Medicine 303; G Herek and J Capitanio, 'AIDS Sigma and Sexual Prejudice' (1999) 42 (7). American Behavioural Scientist 1130; G Herek, 'AIDS and Stigma' (1999) 42 (7) American Behavioural Scientist 1106; Loretta M. Kopelman, 'If HIV/AIDS is Punishment, Who is Bad?' (2002) 27 (2) Journal of Medicine and Philosophy 231; G Herek, J Capitanio and K Widaman, 'HIV-related stigma and knowledge in the United States: prevalence and trends 1991-1999' (2002) 92 (3) American Journal of Public Health 371; R Parker and P Aggleton, P, 'HIV and AIDS-related stigma and discrimination: a conceptual framework and implications for action’ (2003) 57 (1) Social Science \& Medicine 13;

$\mathrm{H}$ Liu and others, 'Relation of sexual risks and prevention practices with individuals' stigmatising beliefs towards HIV infected individuals: an exploratory study' (2005) 81 Sexually Transmitted Infections 511; P Boyce and others, 'Putting sexuality (back) into HIV/AIDS: Issues, theory and practice' (2007) 2 (1) Global Public Health 1; Moji Anderson and 
discrimination originates from outside the UK and consequently this work seeks to ascertain whether the same is true for PLHA within employment in the UK. Consequently, the empirical research used the initial review of non-legal sources and the information obtained from the doctrinal research to construct questions pertaining to the following themes:

- $\quad$ Public attitudes to HIV and PLHA

- Stigma

- Discrimination

- Disclosure. $^{112}$

Overall, the objective of the empirical research undertaken was to determine PLHA's experiences of discrimination and the extent to which they feel adequately protected by the legal framework identified by the doctrinal research undertaken. As became apparent from the doctrinal research, domestic law seeks to protect PLHA from discrimination by deeming them to be disabled. ${ }^{113}$ For that reason, the empirical research sought to answer the following research questions: To what extent did PLHA consider themselves to be disabled? Why and what factors contribute to their identification (or non-identification) as individuals with disabilities? Are they aware of the legal protection currently afforded to them? Do they feel able to disclose their status to their employer and thus benefit from their employer's duty to make reasonable adjustments?

In view of the information sought, it was decided that the adoption of empirical qualitative research was better suited to this area due to its ability to yield richer data. The use of legal doctrinal research would do little to aid understanding of the individual perspectives of PLHA in employment. On the contrary, empirical research was best equipped to illustrate problems with the application of the law in this area and obtain the thoughts and opinions of PLHA on being deemed to be disabled for the purposes of the relevant domestic legislation. In addition, as noted in Chapter 1, there was little relevant existing empirical research within this area. In qualitative research, there is a closer degree of involvement with those who participate in the research and hence a greater sensitivity to the rights of participants as people, rather than as objects of research. ${ }^{114}$ This is especially important when undertaking research in an area as

others, 'HIV/AIDS-related stigma and discrimination: Accounts of HIV-positive Caribbean people in the United Kingdom' (2008) 67 (5) Social Science \& Medicine 790; Anish P. Mahajan and others, 'Stigma in the HIV/AIDS epidemic: A review of the literature and recommendations for the way forward' (2008) 22 AIDS S67; P Hutchinson and R Dhairyawan, 'Shame, stigma, HIV: philosophical reflections’ (2017) Medical Humanities 1; Joint United Nations Programme on HIV/AIDS, 'Confronting discrimination' (UNAIDS 2017). to the following themes: 
personal and sensitive as HIV/AIDS, where accurate answers from participants are dependent on building trust and confidence.

To assist the above, a number of methods from the feminist methodology movement were adopted. In seeking to break down the traditional hierarchies that structure research relationships, feminist researchers oppose what they see as unhealthy barriers that exist between researcher and researched in the research process. ${ }^{115}$ Feminists work towards the establishment of more reciprocal research relationships that are 'derived from authentic relations' ${ }^{116}$ In addition, Henn, Weinstein and Foard posit that feminist researchers believe researchers ought to learn how to listen more and talk less. ${ }^{117}$ With this in mind, the research process was humanised as much as possible and a non-hierarchal research relationship adopted. Participants were viewed very much as partners in the research rather than subjects. They were permitted to ask questions as well as be questioned and the interviews were always conducted in the manner most accessible to the participant. This ranged from conducting interviews in accessible venues through to the use of language and vocabulary most suitable for each particular participant. This non-hierarchical research relationship or what Romm terms a 'collaborative knowledgeconstruction process' assisted in building a rapport with participants and obtaining more accurate responses. ${ }^{118}$

\subsubsection{EMPIRICAL RESEARCH DESIGN}

In order to address the objectives of the empirical research, I undertook semi-structured faceto-face interviews with PLHA. Face-to-face interviews were felt to be most appropriate for this research given the sensitivity of the topic. In fact, the use of face-to-face interviews helped to create a rapport with participants making them more comfortable about discussing topics which were often private and potentially distressing. The use of face-to-face interviews also meant that questions could be adapted as necessary dependent upon the communication skills of the participant and that doubts could be clarified by for example repeating or rephrasing questions. Face-to-face interviews also allowed for the observation of social cues, such as intonation and body language which, helped assist in the interpretation of participants' responses. Finally, as there was the potential for participants to become upset during the research, face-to-face

S Hesse-Biber, and D Leckenby, 'How feminists practice social research' in S Hesse-Biber and M Yaiser (eds), Feminist perspectives on social research (Oxford University Press, 2004); M Henn, M Weinstein, and N Foard, A critical introduction to social research (2nd edn, Sage, 2009); S Hesse-Biber, Handbook of Feminist Research: Theory and Praxis (Sage 2011).

S Reinharz, 'Experiential analysis: A contribution to feminist research' in G Bowles and R Duelli Klein (eds) Theories of Women's Studies (Routledge 1983), 186.

M Henn, M Weinstein and N Foard, A short introduction to social research. (Sage 2009).

N Romm, ‘ Becoming More Accountable: A Comment on Hammersley and Gomm' (1997) 2 (3) Sociological

Research Online <http://www.socresonline.org.uk/2/3/2.html> accessed 1 December 2017, para 6.4. 
interviews enabled me to comfort participants if necessary and safeguard their welfare were they to continue to feel distressed after the conclusion of the interview.

To identify and find initial research participants, I made contact with a number of UK based HIV non-profit organisations. These were the National Aids Trust (NAT), the Terrence Higgins Trust (THT), the African Health Policy Network and NAM Publications. Various assistance was provided by these organisations. By way of example, NAM Publications advertised the research and a call for participants in their HIV weekly email newsletters throughout May 2012 (see Appendix 4). The THT assisted by helping place a call for participants on the UK Community Advisory Board's ${ }^{119}$ message board (see Appendix 5). Once initial participants were identified I employed snowball sampling. At its simplest, this consists of identifying participants who are then used to refer researchers to other participants. ${ }^{120}$ Snowball sampling was particularly useful for this research project due to the degree of trust required to initiate contact with participants as a result of the sensitive subject matter of the research.

20 individuals were interviewed. In the UK, Public Health England provide annual reports in relation to the population of PLHA and all participants were asked to categorise themselves using the descriptors historically employed by Public Health England to monitor the prevalence of the virus amongst the general population. ${ }^{121}$ These are:-

- $\quad$ Men who have sex with men

- $\quad$ People who inject drugs

- $\quad$ Heterosexual black African Men

- Heterosexual non-black African Men

- Heterosexual black African Women

- Heterosexual non-black African Women ${ }^{122}$

To preserve anonymity, all participants were ascribed a moniker to identify their comments throughout the course of this thesis. Despite the small size of this group, the participants were fairly diverse in terms of age, ethnic origin, sexuality and education as can be seen in the table below:

\footnotetext{
119 This a network for community HIV treatment advocates across the UK.

C Noy, 'Sampling Knowledge: The Hermeneutics of Snowball Sampling' (2008) 11 (4) International Journal of Social Research Methodology 327.

121 See for example Public Health England, 'HIV in the UK - 2016 Report' (Public Health England 2016).

122 For the sake of clarity, it should be noted that these are the official descriptors used by Public Health England for the purposes of HIV monitoring and surveillance in the United Kingdom. Individuals were asked to categorise themselves in order to ensure that a variety of individuals with different perspectives were interviewed.
} 


\begin{tabular}{|c|c|c|c|c|c|c|}
\hline Moniker & Sex & Age & Category & $\begin{array}{l}\text { Highest } \\
\text { Educational } \\
\text { Qualification }\end{array}$ & Salary & $\begin{array}{l}\text { Ethnic } \\
\text { Group }\end{array}$ \\
\hline $\mathrm{A}$ & $\mathrm{M}$ & 45 & $\begin{array}{l}\text { Heterosexual non- } \\
\text { black African } \\
\text { Man }\end{array}$ & Post-Graduate & $\begin{array}{l}\text { Less than } \\
£ 9,999\end{array}$ & $\begin{array}{l}\text { White } \\
\text { English }\end{array}$ \\
\hline $\mathrm{C}$ & $\mathrm{M}$ & 52 & $\begin{array}{l}\text { Heterosexual non- } \\
\text { black African } \\
\text { Man }\end{array}$ & Post-Graduate & $\begin{array}{l}\text { More than } \\
£ 60,000\end{array}$ & $\begin{array}{l}\text { White } \\
\text { English }\end{array}$ \\
\hline $\mathrm{D}$ & $\mathrm{M}$ & 41 & $\begin{array}{l}\text { Heterosexual } \\
\text { black African } \\
\text { man }\end{array}$ & $\begin{array}{l}\text { Degree or } \\
\text { equivalent }\end{array}$ & $\begin{array}{l}£ 30,000 \text { - } \\
£ 39,999\end{array}$ & $\begin{array}{l}\text { Black } \\
\text { African }\end{array}$ \\
\hline $\mathrm{E}$ & $\mathrm{M}$ & 46 & $\begin{array}{l}\text { Man who has sex } \\
\text { with men }\end{array}$ & $\begin{array}{l}\text { Degree or } \\
\text { equivalent }\end{array}$ & $\begin{array}{l}\text { More than } \\
£ 60,000\end{array}$ & $\begin{array}{l}\text { White } \\
\text { English }\end{array}$ \\
\hline $\mathrm{F}$ & $\mathrm{F}$ & 32 & $\begin{array}{l}\text { Heterosexual non- } \\
\text { black African } \\
\text { Woman }\end{array}$ & $\begin{array}{l}\text { Degree or } \\
\text { equivalent }\end{array}$ & $\begin{array}{l}£ 10,000 \text { to } \\
£ 19,999\end{array}$ & $\begin{array}{l}\text { White } \\
\text { English }\end{array}$ \\
\hline G & $\mathrm{F}$ & 36 & $\begin{array}{l}\text { Heterosexual non- } \\
\text { black African } \\
\text { Woman }\end{array}$ & $\begin{array}{l}\text { Degree or } \\
\text { equivalent }\end{array}$ & $\begin{array}{l}£ 30,000- \\
£ 39,999\end{array}$ & $\begin{array}{l}\text { White } \\
\text { English }\end{array}$ \\
\hline $\mathrm{H}$ & M & 57 & $\begin{array}{l}\text { Man who has sex } \\
\text { with men }\end{array}$ & Post-Graduate & $\begin{array}{l}£ 20,000- \\
£ 29,999\end{array}$ & $\begin{array}{l}\text { White } \\
\text { English }\end{array}$ \\
\hline I & $\mathrm{M}$ & 40 & $\begin{array}{l}\text { Heterosexual non- } \\
\text { black African } \\
\text { Man }\end{array}$ & $\begin{array}{l}\text { Degree or } \\
\text { equivalent }\end{array}$ & $\begin{array}{l}£ 40,000- \\
£ 49,999\end{array}$ & $\begin{array}{l}\text { White } \\
\text { English }\end{array}$ \\
\hline $\mathrm{J}$ & $\mathrm{M}$ & 42 & $\begin{array}{l}\text { Man who has sex } \\
\text { with men }\end{array}$ & Post-Graduate & $\begin{array}{l}\text { More than } \\
£ 60,000\end{array}$ & $\begin{array}{l}\text { White } \\
\text { English }\end{array}$ \\
\hline $\mathrm{K}$ & $\mathrm{F}$ & 48 & $\begin{array}{l}\text { Heterosexual } \\
\text { black African } \\
\text { Woman }\end{array}$ & $\begin{array}{l}\text { Degree or } \\
\text { equivalent }\end{array}$ & $\begin{array}{l}\text { Less than } \\
£ 9,999\end{array}$ & $\begin{array}{l}\text { Black } \\
\text { African }\end{array}$ \\
\hline $\mathrm{L}$ & $\mathrm{M}$ & 49 & $\begin{array}{l}\text { Heterosexual } \\
\text { black African } \\
\text { man }\end{array}$ & Post-Graduate & $\begin{array}{l}£ 20,000- \\
£ 29,999\end{array}$ & $\begin{array}{l}\text { Black } \\
\text { African }\end{array}$ \\
\hline $\mathrm{M}$ & M & 23 & $\begin{array}{l}\text { Man who has sex } \\
\text { with men }\end{array}$ & $\begin{array}{l}\text { Degree or } \\
\text { equivalent }\end{array}$ & $\begin{array}{l}£ 20,000- \\
£ 29,999\end{array}$ & $\begin{array}{l}\text { White } \\
\text { English }\end{array}$ \\
\hline $\mathrm{N}$ & $\mathrm{M}$ & 27 & $\begin{array}{l}\text { Man who has sex } \\
\text { with men }\end{array}$ & $\begin{array}{l}\text { A Level or } \\
\text { Equivalent }\end{array}$ & $\begin{array}{l}£ 20,000- \\
£ 29,999\end{array}$ & $\begin{array}{l}\text { White } \\
\text { English }\end{array}$ \\
\hline $\mathrm{O}$ & $\mathrm{M}$ & 45 & $\begin{array}{l}\text { Man who has sex } \\
\text { with men }\end{array}$ & $\begin{array}{l}\text { Degree or } \\
\text { equivalent }\end{array}$ & $\begin{array}{l}£ 30,000- \\
£ 39,999\end{array}$ & $\begin{array}{l}\text { White } \\
\text { English }\end{array}$ \\
\hline$P$ & $M$ & 43 & $\begin{array}{l}\text { Man who has sex } \\
\text { with men }\end{array}$ & $\begin{array}{l}\text { Degree or } \\
\text { equivalent }\end{array}$ & $\begin{array}{l}£ 10,000- \\
£ 19,999\end{array}$ & $\begin{array}{l}\text { White } \\
\text { English }\end{array}$ \\
\hline $\mathrm{Q}$ & $\mathrm{M}$ & 53 & $\begin{array}{l}\text { Man who has sex } \\
\text { with men }\end{array}$ & Post-Graduate & $\begin{array}{l}£ 40,000- \\
£ 49,999\end{array}$ & $\begin{array}{l}\text { White: } \\
\text { Italian }\end{array}$ \\
\hline $\mathrm{R}$ & $\mathrm{M}$ & 38 & $\begin{array}{l}\text { Heterosexual } \\
\text { black African } \\
\text { man }\end{array}$ & $\begin{array}{l}\text { Degree or } \\
\text { equivalent }\end{array}$ & $\begin{array}{l}£ 20,000- \\
£ 29,999\end{array}$ & $\begin{array}{l}\text { Black } \\
\text { African }\end{array}$ \\
\hline $\mathrm{S}$ & $\mathrm{F}$ & 33 & $\begin{array}{l}\text { Heterosexual non- } \\
\text { black African } \\
\text { Woman }\end{array}$ & $\begin{array}{l}\text { Degree or } \\
\text { equivalent }\end{array}$ & N/A & $\begin{array}{l}\text { White } \\
\text { English }\end{array}$ \\
\hline $\mathrm{T}$ & $\mathrm{M}$ & 50 & $\begin{array}{l}\text { Man who has sex } \\
\text { with men }\end{array}$ & Post-Graduate & $\begin{array}{l}\text { More than } \\
£ 60,000\end{array}$ & $\begin{array}{l}\text { White } \\
\text { American }\end{array}$ \\
\hline $\mathrm{U}$ & $\mathrm{F}$ & 46 & $\begin{array}{l}\text { Heterosexual non- } \\
\text { black African } \\
\text { Woman }\end{array}$ & Post-Graduate & $\begin{array}{l}\text { Less than } \\
£ 9,999\end{array}$ & $\begin{array}{l}\text { White } \\
\text { English }\end{array}$ \\
\hline
\end{tabular}


Referring back to Public Health England Descriptors, the composition of participants was as follows:

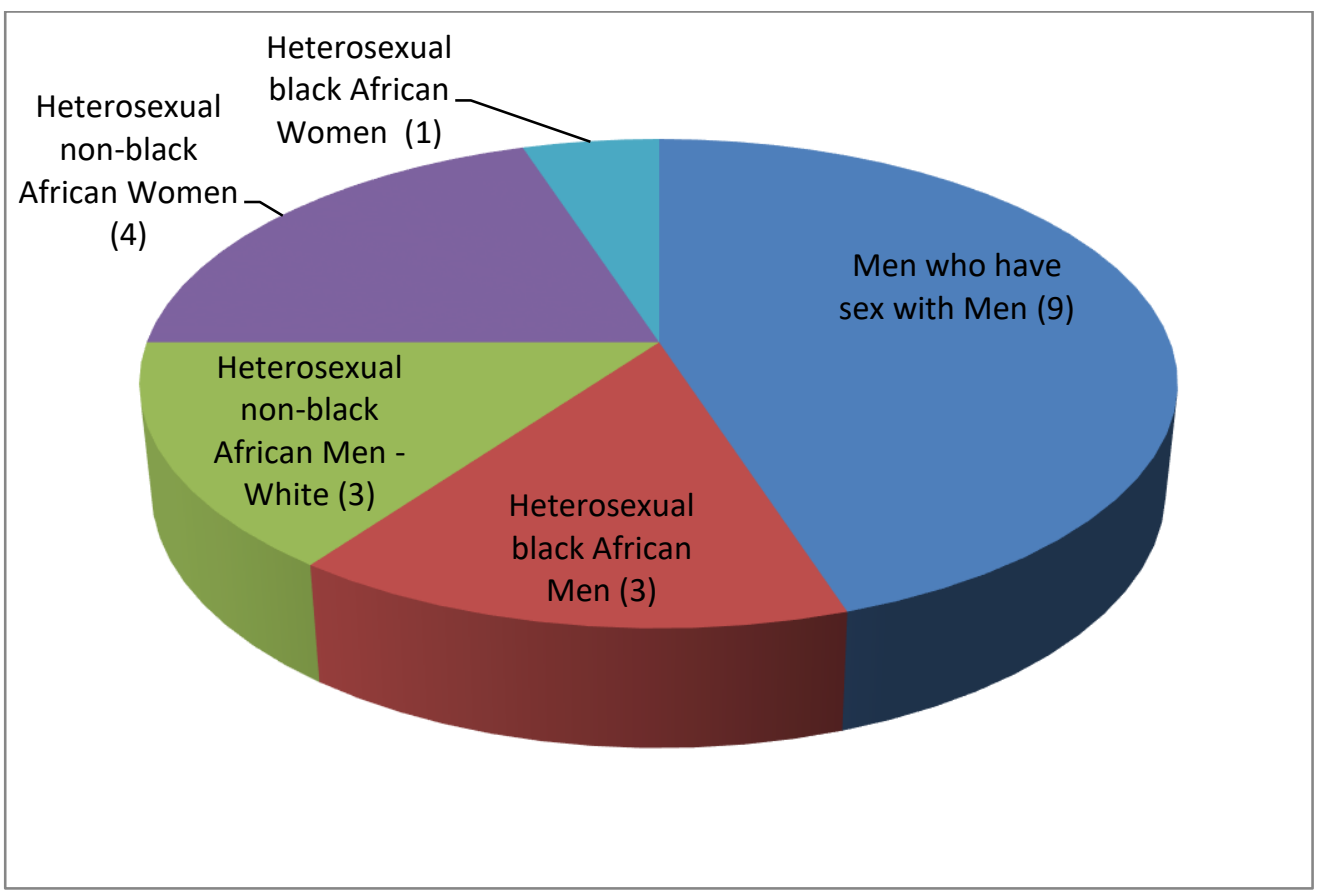

The participants also had varying experiences of disclosing their HIV status to their employers. Of the 20 participants, 13 had disclosed their HIV status to their employer and 6 had not. In addition, 1 individual had the option of disclosing taken away from him as his status was discovered during medical screening by his employer's occupational health department.

\subsubsection{THE QUALITATIVE INTERVIEWS}

Before conducting the interviews an interview schedule was designed. The interviews consisted of open-ended, semi structured questions. Each interview was tape-recorded and transcribed. Interviews typically lasted forty-five minutes to one hour.

The use of primarily open-ended questions was a conscious choice in order to provide participants with sufficient flexibility to provide answers in their own words, whilst enabling structure and focus to be maintained throughout the interview process. Finally, prior to the interviews being undertaken, 2 pilot interviews were conducted with HIV positive friends of the author. Responses and feedback obtained from these interviews helped refine the questions 
asked in the interview schedule. A copy of the final interview schedule is attached in Appendix 6.

All interviews were conducted between March 2012 and April 2013 in a wide variety of locations across the UK. The location of the interview was chosen by the participant in order to help them feel as comfortable as possible. This meant that interviews took place in locations ranging from cafes, libraries and hotel lobbies through to participants' homes, my office and, on more than one occasion, my car. In common with Keenan, the objective was not to set out with the express intention of disclosing my background or experiences, yet I did not want to hide them either. ${ }^{123}$ This meant that I would answer questions when asked with the result that many participants knew of my personal experiences before I had formally commenced the interviews. Some asked after the conclusion of the interview why I was interested in this particular area and some showed no interest at all. Finally, participants were then contacted again in December 2018 and offered the opportunity of expanding upon their previous responses if they so wished and/or reporting any significant changes to the thoughts they expressed in their initial interviews. All participants were however happy with their initial interviews and felt that they accurately reflected their views.

As with any element of human interaction, some participants were easier to relate to than others sometimes because of similarities in age or background. Sometimes, however, it was due to the entirely open and transparent manner in which they related very private experiences and life events to me. Others were more difficult. One particular respondent ('C') was extremely private and managed access to his personal data very carefully. He provided me with his email address and mobile telephone number but not his address. He insisted on meeting on a road in the suburbs of a city and, as I had not been provided with his address, I had no idea whether I was meeting him near his house or somewhere entirely random. This meant that I had some concerns about my personal safety and felt somewhat anxious before travelling to the interview. In order to ensure my safety, my wife followed my location for the duration of my meeting with ' $\mathrm{C}$ ' by tracking the location of my mobile phone using the 'Find my iPhone' function on her iPad. The interview was eventually conducted in my car in a lay-by approximately 3 miles from where I picked ' $\mathrm{C}$ ' up. It turned out that I need not have worried as ' $\mathrm{C}$ ' was a perfectly pleasant individual who provided very open and candid responses. His lack of openness did however cloud my judgement to start with and it took rather longer than with other respondents for us both to establish a rapport.

\subsubsection{THE QUESTIONNAIRES}


Participants were asked to complete a questionnaire immediately before their interview in order to garner key demographic data. The objective of this was to ensure that participants were drawn from a range of backgrounds and also capture key data which might assist in the analysis of the interview data, e.g. the participant's level of education, their income and their employment status.

The questionnaire was designed by analysing and adapting questions used in previous studies associated with PLHA. These were the East London Project, ${ }^{124}$ Gay Men's Sex Survey ${ }^{125}$ and Working with HIV research project. ${ }^{126}$ General questions about an individual's employment status were drawn from the Workplace Employment Relations Survey. ${ }^{127}$ In addition, a number of questions were developed by the author and incorporated into the questionnaire. A copy of the questionnaire can be found in Appendix 7.

\subsubsection{ETHICS}

Due to the sensitive subject nature of the research and to comply with internal University Regulations ethical approval from the College Research Ethics Committee at Nottingham Trent University was obtained before any interviews were undertaken. A copy of my ethical approval correspondence can be found in Appendix 8.

Various measures were taken to ensure that participants fully understood the objectives of the research and how their data would be used. Prior to the commencement of interviews, participants were provided with a protocol which provided them with information about the purpose of the study, how their confidentiality would be maintained, their rights during the study and how their data would be stored and protected both during and after the research process. In this protocol it was made clear to participants that their involvement in the study was entirely voluntary and they were also informed of their rights to withdraw from the study at any time without giving a reason and without consequence. They were further advised that, if they wished, they were able to make a complaint or comment about the conduct of the research at any time to my primary supervisor. A copy of this protocol can be found in Appendix 9 . Informed written consent was then obtained from participants before the interviews formally began. A copy of the consent form provided to participants can be found in Appendix 10. 150 .

F Hickson and others, 'Tactical dangers: Findings from the United Kingdom Gay Men's Sex Survey 2008' (Sigma Research 2008) men and women living with HIV in the UK' (National AIDS Trust 2009). 
A number of processes and procedures were also implemented in order to maintain the confidentiality of participants and their data. Thus, all research materials (recordings and transcripts) were securely stored. Identifying data relating to participants was stored separately from other material, e.g. questionnaire responses. All electronic data was securely stored and password protected. Interview transcripts were anonymised and, as previously discussed, all participants were provided with a moniker when discussed in the body of this study. Finally, factors which could identify any of the participants, e.g. name of employer, name of spouse, have been redacted from any quotes appearing in this thesis.

In recognition of the sensitive and potentially distressing nature of some of the topics that might arise, I took all reasonable steps to minimise any discomfort during the interview process. Occasionally, participants would become upset and I employed a number of strategies to deal with this. Initially, I would say nothing, not out of callousness but because I felt it was important for participants to be able to have a moment to themselves and reflect on the injustice they had suffered without my interjecting. Yet this was rare and invariably I found that participants just wanted the opportunity to have their story heard. Finally, as a precaution I provided information to all participants about how to obtain support from professional HIV organisations if they were to become upset or distressed following the interview.

\subsubsection{DATA INTERPRETATION}

The interview data was analysed and coded using NVivo qualitative analysis software. This analysis involved multiple readings of the interview transcripts to identify themes. The data was then revisited in order to code each instance of these themes systematically and to analyse patterns among them. The coding scheme was developed inductively, with codes identified through data analysis, and deductively, with several codes based on secondary literature. ${ }^{128}$ As in most qualitative studies, the number of interviews analysed here is small. Although the small number of subjects requires caution in drawing generalisations, the in-depth approach made possible by small studies has the potential to reveal considerable nuance and detail.

In order to assist analysis, research training was undertaken by the author. By way of example, the author attended training modules in research methods organised by Nottingham Trent University entitled, 'Quantitative and Qualitative Research Methods', 'Using NVivo', 'Qualitative Data Analysis' and 'Advanced Qualitative Analysis'. The author also attended training by the University of Oxford's Health Experiences Research Group entitled 'Analysing Qualitative Interviews'. 
Analysis was carried out in two phases, both during the fieldwork and after its completion. This involved listening to the interview tapes, transcribing the interviews, reading the transcripts a number of times, summarising the transcripts, coding statements, linking themes, selecting quotations and ultimately, generating theory grounded in the data and writing it up in a coherent fashion.

After reading through all the interviews on more than one occasion, a number of codes were chosen to apply to the data contained in the transcripts. These were: Disclosure, Health, Privacy, Secrecy, Stigma, Sexuality, Relationships, Job Security, Employment Law, Barriers, Death, Discrimination, Experiences of Discrimination, Lack of Knowledge, Self-Stigma, African, Gay, Awareness, Disability, HIV as a Disability, Normality, Legal Protection, Equality Act, Legal Protection, Pre-employment health questionnaires, Fear, Job Security, HIV influencing career choice, Life Changes, Reasonable Adjustments, Self Employed, Personal Adjustments, Career Progression, Dismissal, Employment Benefits, Employment History, Stereotypes, Medicals, Occupational Health, Private Healthcare, Redundancy, Sick Pay and Travel.

At this point, the transcripts were studied carefully again. Illuminative quotations were highlighted and coded using the 43 categories that had been identified. A spider diagram was then produced to make sense of the codes and how they might be grouped into themes. From these 43 codes, 6 overarching themes were identified. These 6 overarching themes were chosen to address the social and legal themes set out in Chapters 6 and 7 and to address the research questions asked. They were: Disclosure, Discrimination, Disability, Law, Adjustments and Experiences of Employment. The transcripts were then read carefully again and each code was assigned to one or more themes. A number of quotations relevant to each of the themes were highlighted and selected for use in this work.

Overall, although the analysis was a lengthy, complex and repetitive process, it facilitated the generation of theory grounded in data. Additionally, as will be shown in Chapters 6 and 7, it was a significant aid in addressing the research questions initially posed by this research.

\subsection{COMBINING THE DOCTRINAL AND EMPIRICAL FINDINGS}

Once both the doctrinal and empirical research had been undertaken, the work sought to utilise the approach advocated by Egan of recognising 'the reciprocal value of each of these approaches in unpacking the meaning, function and operation of law. ${ }^{\text {'29 }}$ Thus, the findings of the empirical 
research were used to critique the law from an external, non-doctrinal perspective. The objective of critiquing the law in this manner was to develop proposals for amendments to UK law which accorded with the wishes of PLHA whilst ensuring compliance with the UK's international and European legal obligations.

To be in a position to use the empirical findings to critique the law in this manner necessitated an 'explanation and translation into legal terms' of the findings relating to participants' 'observations, experiences and data regarding the functioning and the effects of law. ${ }^{130}$ In effect, this meant that key ideas and concepts to emerge from the interview data needed to be systemically identified and collated within interview transcripts before being matched to the corresponding legal themes discussed in Chapter 2.5. The findings which then emerged from the empirical research were then able to offer an alternative perspective in relation to critiquing the law and possible methods of reform.

As Schwarz observes, doctrinal, or what he terms internal method, and external method both have a role to play in legal scholarship and neither is generally used in isolation. ${ }^{131}$ Indeed, the 'boundary between them is often crossed in our day-to-day thinking about law, and current legal scholarship is apt to represent a multi-layered composite of the two. ${ }^{132}$ By employing this approach, the work was not only able to use the empirical findings to enrich the critique and analysis of the normative legal framework, but also to obtain original rich data about an area in which little original research has been undertaken, namely the experiences of PLHA in employment. $3<$ http://doi.org/10.18352/ulr.409> accessed 20 September 2018, 97. 


\section{CHAPTER 3: THE INTERNATIONAL AND EUROPEAN LEGAL FRAMEWORK RELATING TO HIV/AIDS}

\section{$3.1 \quad \underline{\text { INTRODUCTION }}$}

This chapter identifies and discusses the relevant international and European normative sources which afford protection to People living with HIV or with AIDS (PLHA) from discrimination within employment. It identifies the manner in which PLHA are provided protection by each normative source. Understanding and appreciating these normative sources allows an assessment to be made as to whether the Equality Act's (EA 2010) designation of HIV as a disability is consistent with the UK's international and European legal obligations. Consideration is also made of relevant soft law e.g. international policy guidelines.

In this respect, the chapter begins with a discussion of the relevant international law and policy. Thus, in section 3.2 there is discussion of the United Nations (UN) International Covenant on Economic, Social and Cultural Rights, the UN International Covenant on Civil and Political Rights, UNAIDS International Guidelines on HIV/AIDS and Human Rights, the International Labour Organisation's Code of Practice on HIV/AIDS and the World of Work and the UN Convention on the Rights of Persons with Disabilities. Section 3.3 shall then discuss the application of the European Convention on Human Rights to this area before section 3.4 identifies and discusses relevant European Union law, specifically Council Directive 2000/78/EC of 27 November 2000 establishing a general framework for equal treatment in employment and occupation [2000] OJ L 303/16 ('the Framework Directive’).

The chapter will demonstrate that from a normative perspective, the designation of HIV as a disability by the EA 2010 is not inconsistent with the approaches taken at the international and European level. It will also demonstrate that there is no standard method of protecting PLHA from discrimination at the international and European level. Differing sources afford protection from discrimination based upon varying protected characteristics and, with the exception of normative sources grounded in the social model of disability, explicitly protecting PLHA on the basis of disability does not represent a universal approach. ${ }^{133}$

133 The social model is discussed in section 3.2.5. 


\subsection{GLOBAL CONVENTIONS AND POLICY}

The United Kingdom is party to a number of international treaties. ${ }^{134}$ Treaties ratified by signatory states are generally enforceable at an international level, that is by and against other signatory states. Their effect in domestic law depends upon the nature of the signatory state's jurisdiction. Since the United Kingdom is a dualist state, the rights contained in international treaties to which it is party do not form part of English law unless and until such rights are incorporated into domestic law. ${ }^{135}$ Indeed, in J H Rayner (Mincing Lane) Ltd v Department of Trade and Industry ${ }^{136}$ Lord Oliver of Aylmerton stated the general principle of UK law is that 'a treaty is not part of law unless and until it has been incorporated into the law by legislation'. ${ }^{137}$ However, provisions of these treaties are relevant in interpreting ambiguous domestic legislation and determining the scope of such legislation. ${ }^{138}$

\subsubsection{INTERNATIONAL COVENANT ON ECONOMIC, SOCIAL AND CULTURAL RIGHTS}

At a global level, the provisions of the UN's International Covenant on Economic, Social and Cultural Rights 1966 (ICESCR) and the International Covenant on Civil and Political Rights 1966 (ICCPR) offer the greatest labour rights protection amongst the key UN human rights treaties. ${ }^{139}$

The ICESR does not refer explicitly to persons with disabilities or PLHA. However, Article 2(2) provides:

The States Parties to the present Covenant undertake to guarantee that the rights enunciated in the present Covenant will be exercised without discrimination of any

For example the International Covenant on Economic, Social and Cultural Rights 1966, Convention on the Prevention and Punishment of the Crime of Genocide 1948, Convention Against Torture and Other Cruel, Inhuman or Degrading Treatment or Punishment 1984, European Convention for the Prevention of Torture and Inhuman or Degrading Treatment or Punishment 1987. For more detailed discussion of these, and other, treaties see Gerard Quinn and Theresia Degener, Human Rights and Disability: The Current Use and Future Potential of UN Human Rights Instruments in the Context of Disability (UN Publications, 2002).

Dualist states see international law and national law as two essentially different legal systems. When a dualist state signs a treaty, the treaty becomes binding only if it is incorporated by a piece of domestic legislation. However when a monist state, such as France, signs a treaty, the treaty becomes binding automatically by ratification.

ibid, 500 .

See section 8.2 for further discussion as to the relevance of international treaties in interpreting UK legislation.

S Joseph, 'UN Covenants and Labour Rights' in C Fenwick and T Novitz (eds), Human Rights at Work: Perspectives on Law and Regulation (Hart Publishing 2010). 
kind as to race, colour, sex, language, religion, political or other opinion, national or social origin, property, birth or other status.

The UN Committee on Economic, Social and Cultural Rights, the expert committee tasked with interpreting the treaty and monitoring states' progress in its implementation, has adopted a number of General Comments, which serve as authoritative expert interpretations of the treaty's provisions. These make it clear that both persons with disabilities and PLHA fall within the scope of the ICESR. Thus General Comment No. 5 states:

The Covenant does not refer explicitly to persons with disabilities. Nevertheless, the Universal Declaration of Human Rights recognises that all human beings are born free and equal in dignity and rights and, since the Covenant's provisions apply fully to all members of society, persons with disabilities are clearly entitled to the full range of rights recognised in the Covenant. In addition, insofar as special treatment is necessary, States parties are required to take appropriate measures, to the maximum extent of their available resources, to enable such persons to seek to overcome any disadvantages, in terms of the enjoyment of the rights specified in the Covenant, flowing from their disability. Moreover, the requirement contained in article 2 (2) of the Covenant that the rights 'enunciated ... will be exercised without discrimination of any kind' based on certain specified grounds 'or other status' clearly applies to discrimination on the grounds of disability. ${ }^{140}$

Whilst General Comment No. 18 states:

[T]he Covenant prohibits any discrimination in access to and maintenance of employment on the grounds of race, colour, sex, language, religion, political or other opinion, national or social origin, property, birth, physical or mental disability, health status (including HIV/AIDS), sexual orientation, or civil, political, social or other status, which has the intention or effect of impairing or nullifying exercise of the right to work on a basis of equality. ${ }^{141}$

Thus, persons with disabilities enjoy the protection of the ICESR through the ground 'other status', whilst PLHA come within the scope of the ground 'health status', itself an offshoot of the ground 'other status'. 
Of note are articles 6,7 and 12. Article 6 of the ICESR recognises the right to work, which includes 'the right of everyone to the opportunity to gain his living by work which he freely chooses or accepts'. Article 7 recognises the right to just and favourable conditions of work including fair wages, safe working conditions and equal opportunities for promotion. Finally, paragraph 1 of article 12 recognises the right of everyone to the enjoyment of the highest attainable standard of physical and mental health. Whilst paragraph 2(b) requires States Parties to take measures to improve industrial hygiene and paragraph 29(d) requires States Parties to prevent, treat and control combat epidemic, endemic, occupational and other diseases.

\subsubsection{INTERNATIONAL COVENANT ON CIVIL AND POLITICAL RIGHTS}

Article 2 of the ICCPR provides that:

Each State Party to the present Covenant undertakes to respect and to ensure to all individuals within its territory and subject to its jurisdiction the rights recognised in the present Covenant, without distinction of any kind, such as race, colour, sex, language, religion, political or other opinion, national or social origin, property, birth or other status.

In addition Article 26 provides:

All persons are equal before the law and are entitled without any discrimination to the equal protection of the law. In this respect, the law shall prohibit any discrimination and guarantee to all persons equal and effective protection against discrimination on any ground such as race, colour, sex, language, religion, political or other opinion, national or social origin, property, birth or other status.

As with the ICESR, there is no mention of disability in the list of prohibited grounds as the drafters of both did not consider individuals with disabilities 'as a distinct group vulnerable to human rights violations'. ${ }^{142}$ Yet both Articles 2 and 26 indicate that the list of prohibited grounds is not exhaustive. The advantage of such an approach is that those charged with interpreting the Covenant are afforded discretion to extend the list, whilst such discretion is bounded by the existence of enumerated grounds. ${ }^{143}$ Disability is however, covered by the term 'other status' in both of the above Articles due to the fact that the ICESR is drafted on the assumption that it covers all human beings unlike other international treaties that focus on one specific group of people, e.g. the Convention on the Elimination of all Forms of Discrimination against

\footnotetext{
142 Theresa Degener, 'International Disability Law - A New Legal Subject on the Rise: The Interregional Experts'

Meeting in Hong Kong December 13-17 1999’ (2000) 18 Berkeley J Intl Law 180, 187.

143 S Fredman, 'Equality: A New Generation' (2001) 30 (2) Industrial Law Journal 145
} 
Women. ${ }^{144}$ The United Nations General Assembly has also proceeded on the basis that people with disabilities are covered by the ICCPR ${ }^{145}$ and established the office of Special Rapporteur on the Rights of Persons with Disabilities in 2014. ${ }^{146}$ The role of this Special Rapporteur is to monitor and promote the rights of individuals with disabilities utilising a human rights-based approach. $^{147}$

The ICCPR does not specifically mention HIV/AIDS, yet the arguments made above with regard to the universal nature of protection apply similarly to PLHA. In addition, the United Nations Commission on Human Rights ${ }^{148}$ and subsequently the United Nations Human Rights Council adopted a series of resolutions ${ }^{149}$ on human rights and HIV/AIDS confirming that discrimination on the basis of HIV/AIDS status is prohibited by existing international human rights standards. ${ }^{150}$ Paragraph 1 of Resolution 1995/44 of the United Nations Commission on Human Rights also clarifies that the term 'or other status' used in the general non-discrimination clauses of international and regional human rights instruments (such as the International Covenant on Civil and Political Rights) 'should be interpreted to include health status, such as HIV/AIDS'. ${ }^{151}$

The First Optional Protocol to the ICCPR allows individuals to bring complaints to the Human Rights Committee. This Committee has 18 members made up of nationals from States Parties who act as independent experts and oversee commitment to the ICCPR. ${ }^{152}$ However, the United Kingdom is not a signatory to this Protocol. For further detail see Gerard Quinn, 'The International Covenant on Civil and Political Rights' in T. Degener and Y. Koster-Dreese (eds), Human Rights and Disabled Persons, (Martinus Nijhoff 1995) 81. UN General Assembly, Special Rapporteur on the rights of persons with disabilities 26/20, 14 July 2014, UN Doc A/HRC/RES/26/20. ibid.

On 15 March 2006 the UN General Assembly voted to replace United Nations Commission on Human Rights with the UN Human Rights Council.

United Nations High Commissioner for Human Rights 'The protection of human rights in the context of human immunodeficiency virus (HIV) and acquired immunodeficiency syndrome (AIDS). Commission on Human Rights resolution' (UN Docs E/CN.4/RES/1997/33, E/CN.4/RES/1999/49, E/CN.4/RES/2001/51, E/CN.4/RES/2003/47 and E/CN.4/RES/2005/84).

United Nations Human Rights Council 'The protection of human rights in the context of human immunodeficiency virus (HIV) and acquired immune deficiency syndrome (AIDS)' (UN Docs A/HRC/RES/12/27 and A/HRC/RES/16/28). context of human immunodeficiency virus (HIV) and acquired immune deficiency syndrome (AIDS)' (Doc No E/CN.4/1995/176). 


\subsubsection{INTERNATIONAL GUIDELINES ON HIV/AIDS AND HUMAN RIGHTS}

The United Nations has also played an active part in seeking to diminish discrimination and stigma against PLHA. From a historical perspective this can be traced back to the mid-1980s. During this period many governments and the international community began to realise that there were significant human rights implications of HIV/AIDS due to the stigma and discrimination directed at PLHA. ${ }^{153}$ This coupled with the introduction of HAART ensured that there was a commitment on the part of the international community to ensuring that such individuals should not be denied their basic human rights by virtue of their HIV status ${ }^{154}$ Thus, in 1996, at the request of the then United Nations Commission on Human Rights, the United Nations Centre for Human Rights ${ }^{155}$ and the Joint United Nations Programme on HIV/AIDS (UNAIDS) convened the Second International Consultation on HIV/AIDS and Human Rights in Geneva. This brought together thirty-five experts in the field of HIV/AIDS and human rights and the result was the publication of the International Guidelines on HIV/AIDS and Human Rights. These were subsequently updated following a Third International Consultation on HIV/AIDS and Human Rights, which took place in Geneva in 2002, and a consolidated version of the Guidelines was later issued in 2006..$^{156}$

The Guidelines are anchored within a framework of existing international human rights norms and contain normative principles together with practical strategies. The Guidelines cover a number of issues including discrimination, healthcare, information and employment. However, with regard to the current discussion those of most relevance are:

\section{GUIDELINE 1: NATIONAL FRAMEWORK}

States should establish an effective national framework for their response to HIV which ensures a coordinated, participatory, transparent and accountable approach, integrating HIV policy and programme responsibilities across all branches of government.

In addition:

\section{GUIDELINE 5: ANTI-DISCRIMINATION AND PROTECTIVE LAWS}

153

F Lisk, 'A Rights-based approach to addressing HIV/AIDS in the Workplace: The role of and contribution of the ILO and its Constituents' (2007) (1) Law, Social Justice and Global Development Journal <http://www2.warwick.ac.uk/fac/soc/law/elj/lgd/2007_1/lisk> accessed 17 November 2017.

M Weait, 'Criminal Law and the Sexual Transmission of HIV' (2007) 68 (1) The Modern Law Review 121.

The Centre for Human Rights provides secretariat services for United Nations bodies dealing with human rights. The Centre serves as the focal point of the United Nations in the field of human rights. It carries out research and studies on human rights at the request of other bodies.

UNAIDS, 'International Guidelines on HIV/AIDS and Human Rights 2006 Consolidated Version ' (UNAIDS 2006)

(UN Doc No E.06.XIV.4) 
States should enact or strengthen anti-discrimination and other protective laws that protect vulnerable groups, people living with HIV and people with disabilities from discrimination in both the public and private sectors, ensure privacy and confidentiality and ethics in research involving human subjects, emphasise education and conciliation, and provide for speedy and effective administrative and civil remedies.

And:

\section{GUIDELINE 7: LEGAL SUPPORT SERVICES}

States should implement and support legal support services that will educate people affected by HIV about their rights, provide free legal services to enforce those rights, develop expertise on HIV-related legal issues and utilise means of protection in addition to the courts, such as offices of Ministries of Justice, ombudspersons, health complaint units and human rights commissions.

As mere Guidelines the above have no legal effect in either any dualist or monist jurisdiction. However, they illustrate that the virus is not merely complex medically but also politically, legally, economically and culturally. As such, any efforts to successfully combat the virus must recognise this. For this reason, the opinion of UNAIDS in these Guidelines is that, 'the response to HIV must mobilise key actors throughout all branches of government and include all policy areas, since only a combination of well-integrated and coordinated approaches can address the complexities of the epidemic'. ${ }^{157}$

HIV is not explicitly defined as a disability in the Guidelines rather States are given discretion as to how best protect PLHA by the introduction of new anti-discrimination laws or the amendment of existing laws. However, in the context of the right to work, the Guidelines emphasise that PLHA, 'should be provided with reasonable accommodation to be able to continue working as long as possible and, when no longer able to work, be given equal access to existing sickness and disability schemes.' ${ }^{158}$ The concept of reasonable accommodation also exists in other jurisdictions and originated first under United States law as a means of tackling religious diversity. ${ }^{159}$ However, as the notion of reasonable accommodation is intrinsically linked to the concept of disability, this choice of wording indicates that the UN perceives HIV to be a disability. Such an approach is consistent with the approach taken in the ICESR and ICCPR. ${ }^{160}$ 


\subsubsection{THE ILO CODE OF PRACTICE ON HIV/AIDS AND THE WORLD OF WORK}

The United Nations has also sought to provide protection to PLHA via the International Labour Organisation (ILO). This organisation is a tripartite United Nations agency comprised of government, employer and worker representatives. The objective of the ILO is to be a 'unique forum in which the governments and the social partners of the economy of its 187 member states can freely and openly debate and elaborate labour standards and policies'. ${ }^{161}$ In 2001, it published the ILO Code of Practice on HIV/AIDS and the World of Work. ${ }^{162}$ The document was adopted unanimously by all member states in May 2001 and contains 10 key principles that are intended to guide governments', workers' and employers' responses to policy and practice. These principles are also intended to influence the adoption of legislation covering HIV/AIDS in the workplace. Concentrating upon those of most relevance to this work, the principles recognise that HIV/AIDS is a workplace issue and should be treated like any other serious illness/condition in the workplace. There should be no discrimination against workers on the basis of real or perceived HIV status.

The fact that HIV infection alone is not a cause for termination of employment is stressed. As with other conditions, PLHA should be able to work for as long as medically fit in available, appropriate work. Finally, it is noteworthy that the principles highlight the fact that PLHA should be treated no less favourably than those with any other serious illness or condition. Thus, the code states:

\section{Parity with other serious illnesses}

(a) HIV infection and clinical AIDS should be managed in the workplace no less favourably than any other serious illness or condition.

(b)Workers with HIV/AIDS should be treated no less favourably than workers with other serious illnesses in terms of benefits, workers' compensation and reasonable accommodation.

(c) As long as workers are medically fit for appropriate employment, they should enjoy normal job security and opportunities for transfer and advancement. ${ }^{163}$ 
As with the International Guidelines on HIV/AIDS and Human Rights, ${ }^{164} \mathrm{HIV}$ is not explicitly defined as a disability. Instead there are indications of an inclination to position HIV as a disability due to the Code's recommendation of the use of reasonable accommodation as a measure to ensure PLHA's continuance in employment. ${ }^{165}$

In 2010, the ILO adopted an international labour standard to guide legal and policy responses to HIV and AIDS in and through the world of work. ${ }^{166}$ The Recommendation concerning HIV and AIDS and the World of Work establishes key principles for the prevention and treatment of HIV and safeguards the labour rights of people living with or affected by HIV or AIDS. Again, the document recognises that HIV/AIDS is a workplace issue and the importance of eliminating discrimination is emphasised as follows:

10. Real or perceived HIV status should not be a ground of discrimination preventing the recruitment or continued employment, or the pursuit of equal opportunities...

11. Real or perceived HIV status should not be a cause for termination of employment. Temporary absence from work because of illness or caregiving duties related to HIV or AIDS should be treated in the same way as absences for other health reasons...

12. When existing measures against discrimination in the workplace are inadequate for effective protection against discrimination in relation to HIV and AIDS, Members should adapt these measures or put new ones in place, and provide for their effective and transparent implementation.

13. Persons with HIV-related illness should not be denied the possibility of continuing to carry out their work, with reasonable accommodation if necessary, for as long as they are medically fit to do so. Measures to redeploy such persons to work reasonably adapted to their abilities, to find other work through training or to facilitate their return to work should be encouraged, taking into consideration the relevant International Labour Organization and United Nations instruments. ${ }^{167}$

Again, this document does not expressly define HIV as a disability but recommends that, 'Persons with HIV-related illness should not be denied the possibility of continuing to carry out their work, with reasonable accommodation if necessary, for as long as they are medically fit to

UNAIDS, 'International Guidelines on HIV/AIDS and Human Rights 2006 Consolidated Version ’ (UNAIDS 2006) (Doc No E.06.XIV.4). 
do so. ${ }^{\text {'68 }}$ Thus, as with its earlier Code of Practice on HIV/AIDS and the World of Work, ${ }^{169}$ there is a willingness to perceive HIV as a disability.

\subsubsection{THE UN CONVENTION ON THE RIGHTS OF PERSONS WITH DISABILITIES}

In December 2006, following prolonged lobbying by disability rights activists, the UN General Assembly adopted the Convention on the Rights of Persons with Disabilities (2006) (CRPD), which entered into force in May 2008 after receiving the requisite number of ratifications. ${ }^{170}$ The principles of equality and non-discrimination run through the CRPD ${ }^{171}$ like 'a red thread' ${ }^{\prime 72}$ and the UK Government ratified the CRPD in June 2009. ${ }^{173}$ The CRPD addresses many of the issues faced by PLHA, but it does not explicitly include HIV or AIDS. The UK Government also ratified the Optional Protocol to the CRPD in August 2009, which provides for two implementation and monitoring procedures. First, it allows individuals who feel that their CRPD rights have not been met to complain to the United Nations CRPD committee, though this can only be done after all other domestic routes have been exhausted. Second, it allows the UN Committee on the Rights of Persons with Disabilities authority to undertake inquiries into States Parties if it 'receives reliable information indicating grave or systematic violations by a State Party of rights set forth in the [CRPD]'. ${ }^{174}$ The UN Committee on the Rights of Persons with Disabilities can make recommendations in both instances; however, such recommendations are not legally binding upon the Government as consistent with other treaty bodies tasked with monitoring complaints, the CRPD Committee is not a court with judicial powers. ${ }^{175}$ Instead, its

ibid para 13.

International Labour Organisation, 'An ILO Code of Practice on HIV/AIDS and the World of Work' (2001 International Labour Organisation).

For analysis of the CRPD in relation to European law see A Lawson, 'The UN Convention on the Rights of Persons with Disabilities and European Disability Law: A Catalyst for Cohesion' in G Quinn and O Arnardottir (eds) The UN Convention on the Rights of Persons with Disabilities: European and Scandinavian perspectives (Martinus Nijhoff 2009); L Waddington, 'Breaking New Ground: The Implications of Ratification of the UN Convention on the Rights of Persons with Disabilities for the European Community' in G Quinn and O Arnardottir.( eds) The UN Convention on the Rights of Persons with Disabilities: European and Scandinavian perspectives. (Martinus Nijhoff 2009); L Waddington and A Broderick, Promoting Quality and Non-Discrimination for Persons with Disabilities' (Council of Europe 2017).

For detailed discussion of the CRPD see A Broderick, The long and winding road to equality and inclusion for persons with disabilities: The United Nations Convention on the Rights of Persons with Disabilities (Intersentia 2015).

L Waddington,' Fine-tuning non-discrimination law: Exceptions and justifications allowing for differential treatment on the ground of disability' (2015) 15 (1-2) International Journal of Discrimination and the Law 11.

For analysis of the CRPD in relation to UK law see S Fraser Butlin, 'The UN Convention on the Rights of Persons with Disabilities: Does the Equality Act 2010 Measure up to UK International Commitments?’ (2011) 40 (4) Industrial Law Journal 428.

Article 6, Optional Protocol to the Convention on the Rights of Persons with Disabilities.

Antonia Jones and others, 'The UN Inquiry into the Rights of Persons with Disabilities in the UK' House of 
effectiveness is dependent upon States parties recognising the competence of the Committee and abiding by decisions made.

To date, the UK is the only country to be investigated by the UN under the procedure contained in the Optional Protocol. ${ }^{176}$ This investigation followed information received by the UN Committee on the Rights of Persons with Disabilities in early 2012 about 'the alleged adverse impact on persons with disabilities of the implementation of a process of reforms of legislation and policies in the [UK].' ${ }^{177}$ This was followed by a formal request to the UN Committee on the Rights of Persons with Disabilities in April 2013 from a 'number of organisations of persons with disabilities alleging that serious and systematic violations of the provisions of the Convention were occurring against persons with disabilities. ${ }^{178}$ The inquiry found that the reforms had led to 'grave and systematic' ${ }^{179}$ violations of the rights of disabled people, and emphasised that changes were required to a number of welfare provisions which are beyond the scope of this thesis.

Of more specific note though is that as the EU ratified the CRPD in November 2009, the UK enacted a Statutory Instrument, The European Communities (Definition of Treaties) (UN CRPD) Order, SI 2009/1181. This declared the CRPD to be one of the Community treaties within the definition of section 1(2) of the European Communities Act 1972. This means that the provisions of the convention must be given effect to and enforced accordingly. In addition, Fraser Butlin is of the opinion that EU ratification of the convention will play a significant role in the interpretation of EU directives, particularly with regard to interpretation of Council Directive 2000/78/EC of 27 November 2000 establishing a general framework for equal treatment in employment and occupation [2000] OJ L 303/16 ('Framework Directive'). ${ }^{180}$

The European Court of Human Rights has also referred the CRPD in two relatively recent judgments namely Glor v Switzerland and Kiss v Hungary. ${ }^{181}$ This is significant due to the fact that UK legislation must, so far as it is possible to do so, be read and given effect in a way which is compatible with the European Convention of Human Rights due to the requirements of

Commons Library Research Paper, Number 07367, 27 March 2017. ibid, 6 .

UN Committee on the Rights of Persons with Disabilities, Inquiry concerning the United Kingdom of Great Britain and Northern Ireland carried out by the Committee under article 6 of the Optional Protocol to the Convention (6 October 2016), UN doc CRPD/C/15/R.2/Rev.1, para 2.

ibid, para. 3 .

ibid, para 113 .

S Fraser Butlin, 'The UN Convention on the Rights of Persons with Disabilities: Does the Equality Act 2010 Measure up to UK International Commitments?' (2011) 40 (4) Industrial Law Journal 428.

Glor v. Switzerland 2009-III 33; Kiss v Hungary App no 38832/06 (ECtHR, 20 May 2010). 
Section 3(1) Human Rights Act 1998. Consequently when human rights are determined with reference to the CRPD, UK legislation will have to be read in conformity with those rights.

The CRPD does not include a definition of 'disability' or 'persons with disabilities', nor does it expressly mention HIV or AIDS. However, the convention's preamble recognises that, 'disability is an evolving concept and that disability results from the interaction between persons with impairments and attitudinal and environmental barriers that hinders their full and effective participation in society on an equal basis with others. ${ }^{182}$

Article 1 further states:

Persons with disabilities include those who have long term physical, mental, intellectual or sensory impairments which in interaction with various barriers may hinder their full and effective participation in society on an equal basis with others.

Whilst Article 2 defines discrimination on the basis of disability as:

... any distinction, exclusion or restriction on the basis of disability which has the purpose or effect of impairing or nullifying the recognition, enjoyment or exercise, on an equal basis with others, of all human rights and fundamental freedoms in the political, economic, social, cultural, civil or any other field. It includes all forms of discrimination, including denial of reasonable accommodation.

The concept of disability contained in Article 1 of the CRPD is broad enough to include HIV or AIDS due to its use of what is termed the social model of disability. ${ }^{183}$ Indeed, in order to adequately understand the drafting and social construction of the CRPD and other pieces of legislation, it is important to consider how disability itself has been socially constructed. Therefore, from a social perspective, it is generally accepted that there are two dominant models of disability: the medical model of disability and the social model of disability. ${ }^{184}$

The medical model of disability locates disability within the individual. Disability is a medical condition, and consequently, like all other conditions it can be treated by doctors to ensure that

\footnotetext{
182 Preamble to the Convention on the Rights of Persons with Disabilities, para (e).

183 R Elliott, L Utyasheva and E Zack, 'HIV, disability and discrimination: making the links in international and domestic human rights law' (2009) 12 Journal of the International AIDS Society 29.

In addition, a number of more recent models have been developed based, in large part, on the social model e.g. the minority rights approach, the universalist approach, the human rights-based approach and the capabilities approach. For further discussion of these see Broderick, A (2015), The long and winding road to equality and inclusion for persons with disabilities: The United Nations Convention on the Rights of Persons with Disabilities, Cambridge: Intersentia, 21-31.
} 
its symptoms are ultimately alleviated or eradicated. ${ }^{185}$ The nature of the model is that from a social perspective the disabled individual is placed in the 'sick role'. ${ }^{186}$ This role contains four key elements. Firstly, the sick person is not held responsible for their illness - it is due to biological factors over which they have no control. Following on from this primary tenet, it is advanced that (2) the sick person is exempted from normal social obligations and (3) is in a socially legitimate position if (4) they co-operate with medical professionals in order to work towards recovery. ${ }^{187}$

The influence of the medical model is evidenced by the World Health Organisation's development of an International Classification of Impairments, Disabilities and Handicaps. ${ }^{188}$ This document contains the following definitions:-

Impairment: a permanent or transitory psychological, physiological or anatomical loss or abnormality of structure or function.

Disability: any restriction or prevention of the performance of an activity, resulting from an impairment, in the manner or within the range considered normal for a human being.

Handicap: a disability that constitutes a disadvantage for a given individual in that it limits or prevents the fulfilment of a role that is normal depending on age, sex, social and cultural factors for the individual.

From the above it is apparent that the definitions of impairment and disability developed by the WHO in this document essentially favour the medical model of disability. ${ }^{189}$ Whilst the medical model has been the dominant model of disability, it has been subjected to repeated criticism.

For further commentary see C Barnes, 'A Working Social Model? Disability, Work and Disability Politics in the Twenty-First Century' (2000) 20 Critical Social Policy 221 and Michael Oliver, Understanding Disability: From Theory to Practice (2nd edition, Palgrave Macmillan 2009).

T Parsons, 'Definitions of Health and Illness in the Light of American Values and Social Structure' in E Jaco (ed), Patients, Physicians and Illness (Free Press 1958); M Varul, 'Talcott Parsons, the Sick Role and Chronic Illness' (2010) 16 (2) Body \& Society 72. J Drimmer, 'Cripples, Overcomers and Civil Rights: Tracing the Evolution of Federal Legislation and Social Policy for People with Disabilities' (1992) 40 (5) UCLA Law Review 1341.

World Health Organisation, International Classification of Impairments, Disabilities and Handicaps: a Manual of Classification Relating to the Consequences of Disease (World Health Organisation 1980).

The International Classification of Impairments, Disabilities and Handicaps was part of a set of classifications developed by the WHO for application to various aspects of health and disease. The best established is the International Statistical Classification of Diseases which has been developed internationally since 1893 . There have been ten major revisions with the most recent being ICD-10. 
Indeed, the prominent disability academic, Michael Oliver, has been highly critical of this model of disability. ${ }^{190} \mathrm{He}$ contends that there are two fundamental problematic aspects to the medical model of disability. Firstly, it locates the 'problem' of disability within the individual and secondly, it sees the causes of this problem as stemming from the functional limitations or psychological losses which are assumed to arise from disability. ${ }^{191}$ Further criticism derives from that fact that a cure for many disabilities may never be found, and in any event, persons with disabilities are quite capable of participating in society and the practices of confinement that accompany the sick role are unacceptable. ${ }^{192}$

To combat these inadequacies, the social model of disability was developed in the 1970s by activists in the Union of the Physically Impaired Against Segregation (UPIAS). The classic definition of the social model comes in the UPIAS document, Fundamental Principles of Disability. According to the UPIAS:

In our view, it is society which disables physically impaired people. Disability is something imposed on top of our impairments by the way we are unnecessarily isolated and excluded from full participation in society. Disabled people are therefore an oppressed group in society. To understand this it is necessary to grasp the distinction between the physical impairment and the social situation, called 'disability', of people with such impairment. Thus we define impairment as lacking all or part of a limb, or having a defective limb, organism or mechanism of the body and disability as the disadvantage or restriction of activity caused by a contemporary social organisation which takes little or no account of people who have physical impairments and thus excludes them from participation in the mainstream of social activities. ${ }^{193}$

Thus, according to the social model, disability is the outcome of environmental, physical, attitudinal or psychological barriers that prevent people with physical or mental impairments from participating in their communities on an equal basis with others. ${ }^{194}$ Significantly, a distinction is made between the biological (impairment) and the social (disability) interface in relation to individuals. According to Oliver and Barnes, ' $[\mathrm{t}]$ his was necessary to direct attention away from the general tendency to view disability as an individual problem rather than a

M Oliver, Understanding Disability: From Theory to Practice (2nd edition, Palgrave Macmillan 2009).

Oliver consequently advocates the use of the term "Individual model" as opposed to "Medical model".

J Kaplan, 'The Definition of Disability: Perspective of the Disability Community' (2000) 3 (2) Journal of Health Care, Law \& Policy 3 (2) 352.

M Oliver, Understanding Disability: From Theory to Practice (Palgrave Macmillan 1996) 22.

M Oliver, The Politics of Disablement. (Macmillan 1990); J Morris, Pride against Prejudice: Transforming Attitudes to Disability (The Women's Press Ltd. 1991); J Swain and others (eds) Disabling Barriers Enabling Environments (Sage Publications 1993); T Shakespeare, K Gillespies-Sells and D Davies, The Sexual Politics of Disability: Untold Desires (Cassell 1996); C Barnes, ‘A Working Social Model? Disability,Work and Disability Politics in the 21 st century’ (2000) 4 Critical Social Policy 441. 
socio/political issue - a tendency which allows policy makers to focus on 'people fixing' rather than disabling barriers. ${ }^{195}$ These barriers can range from individual prejudice to institutional discrimination and from inaccessible public buildings to inaccessible transport systems. ${ }^{196}$ As Wendell notes:

The cultural habit of regarding the condition of the person, not the built environment or the social organization of activities, as the source of the problem, runs deep. For example, it took me several years of struggling with the heavy door to my building, sometimes having to wait until a person came along, to realize that the door was an accessibility problem, not only for me, but for others as well. And I did not notice, until one of my students pointed it out, that the lack of signs that could be read from a distance at my university forced people with mobility impairments to expand a lot of energy unnecessarily, searching for rooms and offices. I interpreted it, automatically, as a problem arising from my illness (as I did with the door), rather than as a problem arising from the built environment that has been created for too narrow a range of people and situations. ${ }^{197}$

The social model has particular application to HIV due to the societal stigma associated with the virus. Even asymptomatic PLHA are subjected to high levels of stigma ${ }^{198}$ and so the model's acknowledgement that disability results not solely from impairment has had a profound impact upon the manner in which disability is perceived and constructed. The World Health Organisation replaced the International Classification of Impairments, Disabilities and Handicaps with the International Classification of Functioning, Disability and Health (ICF) in $2001 .{ }^{199}$ This new system of classification is, according to the WHO, based on an integration of the medical and social model, 'in order to provide a coherent view of different perspectives of health from a biological, individual and social perspective. ${ }^{200}$ In accompanying guidance to the ICF the WHO state:

World Health Organisation, International Classification of Functioning, Disability and Health (ICF) (World Health Organisation 2001).

For analysis see Marijke de Keijinde Wrankrijker, 'The long way from the International Classification of Impairments, Disabilities and Handicaps (ICIDH) to the International Classification of Functioning, Disability and Health (ICF)' (2003) 25 (11-12) 561. 
Disability is a complex phenomena that is both a problem at the level of a person's body, and a complex and primarily social phenomena. Disability is always an interaction between features of the person and features of the overall context in which the person lives, but some aspects of disability are almost entirely internal to the person, while another aspect is almost entirely external. In other words, both medical and social responses are appropriate to the problems associated with disability; we cannot wholly reject either kind of intervention. ${ }^{201}$

However, the social model has also been subject to criticism by scholars. ${ }^{202}$ Degener asserts that due to the lack of a strong distinction between 'characteristics and treatment' the social model fails to 'give any guidance as how to alternatively legally define disability'. ${ }^{203}$ Feminist scholars in particular have argued that with its over emphasis on societal factors the model fails to take sufficient account of impairment as part of the personal experience of people with disabilities. ${ }^{204}$ For this reason, although one of the strengths of the social model is its ability to recognise the role played by environmental barriers and social attitudes, 'to suggest that this is all there is, is to deny the personal experience of physical and intellectual restrictions, of the fear of dying. ${ }^{205}$ Whereas Shakespeare and Watson assert that a failure to acknowledge the role of impairment risks isolating individuals with disabilities from social and political engagement, whilst also failing to acknowledge the true life history of individuals with disabilities. ${ }^{206}$ Consequently, 'if our analysis does not include impairment, disabled people may be reluctant to identify with the disability movement, and commentators may reject our arguments as being 'idealistic' and ungrounded. We are not just disabled people, we are also people with impairments, and to pretend otherwise is to ignore a major part of our biographies. ${ }^{207}$

By the language employed by the CRPD in both the preamble and Article 1, it is clear that it represents a move towards the social model. The embracing of the social model of disability is ground-breaking. The CRPD 'self-consciously seeks to realign the 'civil rights' model on disability - with its attendant suite of civil and political rights - with an equal emphasis on

World Health Organization, Towards a Common Language for Functioning, Disability and Health (World Health Organization 2002) 9.

See for example J Morris, Pride Against Prejudice (Women's Press 1991); S French, 'Setting a record straight' in J. Swain, V. Finkelstein, S. French and M. Oliver (eds), Disabling Barriers - Enabling Environments (Sage 1993); L Crow, 'Including all our lives' in J Morris (ed) Encounters with Strangers: Feminism and Disability (Women's Press 1996).

T Degener, “ The Definition of Disability in German and Foreign Discrimination Law' (2006) Disability Studies Quarterly 26 (2).

J Morris, Pride Against Prejudice (Women's Press 1991).

ibid, 10 .

Tom Shakespeare and Nicholas Watson, 'The social model of disability: an outdated ideology?' (2001) 2 Research in Social Science and Disability 9.

ibid 15. 
social justice'. ${ }^{208}$ This builds on Quinn and Degener's earlier work which introduced the human rights model of disability, stating that such a model 'focuses on the inherent dignity of the human being and... places the individual centre stage in all decisions affecting him/her and, most importantly, locates the main 'problem' outside the person and in society'. ${ }^{209}$ Hence the CRPD's 'tactical reframing of disability as a social construction emphasises discrimination and affronts to human dignity inherent in medical and charity models and builds the foundation for disability as a human rights issue. ${ }^{210}$ More recently in General Comment 6 the UN Committee on the Rights of Persons with Disabilities has stated that the CRPD is based upon a new model of disability, that of inclusive equality. Drawing extensively upon a submission to the Committee by Sandra Fredman and others, ${ }^{211}$ General Comment 6 states:

Inclusive equality is a new model of equality developed throughout the Convention. It embraces a substantive model of equality and extends and elaborates on the content of equality in: (a) a fair redistributive dimension to address socioeconomic disadvantages; (b) a recognition dimension to combat stigma, stereotyping, prejudice and violence and to recognise the dignity of human beings and their intersectionality; (c) a participative dimension to reaffirm the social nature of people as members of social groups and the full recognition of humanity through inclusion in society; and (d) an accommodating dimension to make space for difference as a matter of human dignity. The Convention is based on inclusive equality. ${ }^{212}$

As shall be examined later, whatever terminology or analysis is applied, the concept of disability employed in the CRPD contrasts sharply with the UK's domestic legislation and has the potential to empower PLHA on a global basis. Indeed, in their joint report, Disability and HIV Policy Brief, the United Nations Office of the High Commissioner for Human Rights, the World Health Organization and UNAIDS endorsed the applicability of the CRPD and its disability anti-discrimination framework to PLHA. ${ }^{213}$ This report states:

Gerard Quinn and Eilionoir Flynn, 'Transatlantic Borrowings: The Past and Future of EU Non-Discrimination Law and Policy on the Ground of Disability' (2012) 60 (1) Evolutions in Antidiscrimination law in Europe and North America 23.

Gerard Quinn and Theresia Degener (eds) The current use and future potential of United Nations human rights instruments in the context of disability (United Nations 2002), 14.

J Lord, D Suozzi and Allyn Taylor, 'Lessons from the Experience of U.N. Convention on the Rights of Persons with Disabilities: Addressing the Democratic Deficit in Global Health Governance' (2010) 38 (3) The Journal of Law, Medicine \& Ethics 564.

Sandra Fredman and others, Achieving Transformative Equality for Persons with Disabilities: Submission to the CRPD Committee for General Comment No.6 on Article 5 of the UN Convention on the Rights of Persons with Disabilities (Oxford Human Rights Hub 2017).

UN Committee on the Rights of Persons with Disabilities, General Comment No. 6 on equality and non-discrimination, adopted at the ninetenth session of the Committee (14 February-9 March 2018) on 9 March 2018, UN Doc. CRPD/C/GC/6, para. 11. 
The Convention does not explicitly refer to HIV or AIDS in the definition of disability. However, States are required to recognise that where persons living with HIV (asymptomatic or symptomatic) have impairments which, in interaction with the environment, results in stigma, discrimination or other barriers to their participation, they can fall under the protection of the Convention.

States parties to the Convention are required to ensure that national legislation complies with this understanding of disability. Some countries have accorded protection to people living with HIV under national disability legislation. Other countries have adopted anti-discrimination laws that either explicitly include discrimination on the basis of HIV status or can be interpreted to do so. Such laws offer a means of redress against HIV-related discrimination in a number of areas, such as employment or education. ${ }^{214}$

Article 5 of the CRPD outlines States Parties' obligations in respect of ensuring quality and non-discrimination. Article 5(1) outlines that:

States Parties recognise that all persons are equal before and under the law and are entitled without any discrimination to the equal protection and equal benefit of the law.

Of particular note is Article 5(2) which prohibits discrimination by providing that:

States Parties shall prohibit all discrimination on the basis of disability and guarantee to persons with disabilities equal and effective legal protection against discrimination on all grounds.

There is no explicit reference to direct discrimination, indirect discrimination or victimisation as there is for the purposes of UK domestic law. ${ }^{215}$ This was a deliberate omission following an impassioned debate regarding the wording of Article 5. ${ }^{216}$ Yet the scope of the CRPD is still wide-ranging and both Waddington and Broderick ${ }^{217}$ posit that it is capable of including not only direct and indirect discrimination but also a denial of reasonable accommodation, harassment, instructions to discriminate, discrimination by association, multiple discrimination

UNAIDS, WHO and OHCHR, Disability and HIV Policy Brief (United Nations 2009) <www.who.int/disabilities/jc1632_policy_brief_disability_en.pdf> accessed 23 November 2017. 
and discrimination based on perceived or past disability. In particular, Broderick ${ }^{218}$ notes the CRPD Committee's concluding observations to Spain where the Committee urged, 'the State party to expand the protection of discrimination on the grounds of disability to explicitly cover multiple disability, perceived disability and association with a person with a disability, and to ensure the protection from denial of reasonable accommodation, as a form of discrimination, regardless of the level of disability. ${ }^{219}$ Indeed, the Office of the United Nations High Commissioner for Human Rights has reported that the CRPD covers all forms of discrimination including, 'direct discrimination, indirect discrimination, discrimination by association, structural or systemic discrimination, discrimination on the basis of perceived impairment, disability-based exclusion and segregation in any field of social life, disability-based violence, denial of access, denial of reasonable accommodation and failure to provide procedural accommodation in the context of access to justice. ${ }^{220}$ In addition, the UN Committee on the Rights of Persons with Disabilities, has made clear in General Comment 6 that the duty to prohibit discrimination includes direct discrimination, indirect discrimination, denial of reasonable accommodation, harassment, multiple discrimination, intersectional discrimination and discrimination on the basis of disability. ${ }^{221}$

Article 5(3) introduces the concept of reasonable accommodation by stating:

In order to promote equality and eliminate discrimination, States Parties shall take all appropriate steps to ensure that reasonable accommodation is provided.

The obligation to provide reasonable accommodation is not however absolute as made clear by Article 2. This Article defines a 'reasonable accommodation' as 'necessary and appropriate modification and adjustments not imposing a disproportionate or undue burden.' Further, 'determining whether an accommodation would entail a "disproportionate or undue burden" requires an assessment of the proportional relationship between the means employed (including time, cost, duration and impact) and the aim, which is the enjoyment of the right concerned'.222 Convention on the Rights of Persons with Disabilities (Intersentia 2015), 97. under article 5 of the Convention on the Rights of Persons with Disabilities". UN doc A/HRC/34/26, para 24. 
Reasonable accommodation is a concept embedded in both $\mathrm{EU}^{223}$ and domestic ${ }^{224}$ law and one which will be explored further in sections 3.4 and 4.3.7.

Article 5(4) provides:

Specific measures which are necessary to accelerate or achieve de facto equality of persons with disabilities shall not be considered discrimination under the terms of the present Convention.

This allows States Parties to take positive action measures, if they so wish, in respect of individuals with disabilities. Such measures can either be temporary or permanent in nature. The concept of positive action is also provided for by Article 26 of the EU Charter of Fundamental Rights and Article 7 of the Framework Directive. From a domestic perspective The Disabled Persons (Employment) Act 1944 introduced an employment quota scheme compelling all employers with more than 20 employees to employ disabled people. However, 'its implementation was not vigorously pursued, and little effort was made to penalise employers who failed to satisfy the recruitment target. ${ }^{225}$ Consequently, the quota system was abandoned following the passage of the Disability Discrimination Act $1995 .^{226}$

Article 6 of the CRPD introduces the concept of multiple discrimination. Thus Article 6(1) provides:

States Parties recognise that women and girls with disabilities are subject to multiple discrimination, and in this regard shall take measures to ensure the full and equal enjoyment by them of all human rights and fundamental freedoms.

Multiple discrimination refers to instances where 'individuals or groups of individuals face discrimination on more than one of the prohibited grounds ${ }^{227}$ and can be either cumulative or additive in nature. ${ }^{228}$ Cumulative multiple discrimination takes place where a person is treated less favourably because of more than one protected characteristic, but each type of See Article 5 of the Framework Directive. The concept of reasonable accommodation for the purposes of EU Law is discussed at 2.4.2. See s 20 Equality Act 2010. Domestic law refers to 'reasonable adjustment' rather than reasonable accommodation. The concept is discussed further at 3.2.8.

G Mercer and C Barnes, 'Changing Disability Policies in Britain' in C Barnes and G Mercer (eds ) Disability Policy and Practice: Applying the Social Model, (The Disability Press, 2004). Section 61 Disability Discrimination Act 1995

L Waddington and A Broderick, Promoting Quality and Non-Discrimination for Persons with Disabilities' (Council of Europe 2017), 17. 
discrimination occurs on separate occasions. ${ }^{229}$ In contrast, additive multiple discrimination arises when 'a person is treated less favourably because of more than one protected characteristic and, although the two forms of discrimination happen at the same time, they are not related to each other. ${ }^{230}$ Solanke provides the example of a lesbian 'who experiences both homophobia and sexist bullying from her employer during the same incident.' ${ }^{231}$

Thus, although multiple discrimination often 'manifests itself as intersectional discrimination', it is distinct from it and the "two terms are used as synonyms even though they do not mean the same thing: intersectionality refers to a philosophy of inequality whereas multiple discrimination describes the occurrence of discrimination on two or more grounds. ${ }^{232}$ Intersectional discrimination thus occurs when 'the discrimination involves more than one protected characteristic and it is the unique combination of characteristics that results in discrimination, in such a way that they are completely inseparable. This often occurs as a result of stereotyped attitudes or prejudice relating to particular combinations of the protected characteristics. ${ }^{233}$ Synergy is the key element of intersectional discrimination ${ }^{234}$ and 'it is the unique combination of characteristics that results in discrimination, in such a way that they are completely inseparable.' 235 General Comment 6 clarifies that both multiple and intersectional discrimination are covered by the CRPD. ${ }^{236}$

Returning briefly to the CRPD, the only specific reference to employment is at Article 27 which states, inter alia, that disabled individuals have the right to earn a living through work that they freely choose and in workplaces that are accessible and inclusive. Governments should promote this right to work by ensuring disabled individuals are protected against discrimination in employment and are entitled to reasonable adjustments.

The definition of disability employed by the CRPD represents a significant challenge to the definition employed by the Equality Act 2010. Whilst the Equality Act 2010 on the whole utilises the medical model, the CRPD combines the social model of disability with a rights-

Al Jumard v Clywd Leisure Ltd and Others [2008] UKEAT/0334/07/ZT, [2008] I.R.L.R. 345.

Nwoke v Government Legal Service and Civil Service Commissioners (1996) 28 Equal Opportunities Review 6. Iyiola Solanke, 'Infusing the Silos in the Equality Act 2010 with Synergy' (2011) 40 (4) Industrial Law Journal 336, 344. ibid

Government Equalities Office, The Equality Bill: Assessing the impact of a multiple discrimination provision (Government Equalities Act 2009) 11.

Iyiola Solanke, 'Intersectionality and the "anti-stigma principle" - disrupting anti-discrimination law' (2017) 61. Discrimination Law Association Briefings 10, 13.

Iyiola Solanke, 'Infusing the Silos in the Equality Act 2010 with Synergy' (2011) 40 (4) Industrial Law Journal 336, 345 .

UN Committee on the Rights of Persons with Disabilities, General Comment No. 6 on equality and non-discrimination, adopted at the nineteenth session of the Committee (14 February-9 March 2018) on 9 March 2018, UN Doc. CRPD/C/GC/6, para. 19. 
based approach. In addition, the European Court of Human Rights is now referring to the CRPD in its judgments. ${ }^{237}$ This clearly illustrates that the definition of 'disability' employed by the Equality Act 2010 will need to be amended to conform with the CRPD and any possible future European Court of Human Rights judgment of a relevant nature. ${ }^{238}$ However, in respect of PLHA the EA 2010's designation of HIV as a disability indicates a clear use of the social model of disability which, will be discussed further in section 4.2, demonstrates consistency with the UN CRPD.

\subsubsection{CONCLUSION}

As the United Kingdom is a dualist state, the rights contained in the ICESR and ICCPR do not form part of English law as the same have not been incorporated into domestic law. ${ }^{239}$ This is also the case for the soft law identified in the ILO Code of Practice on HIV/AIDS and the World of Work. ${ }^{240}$ Despite this, consideration of the manner in which HIV/AIDS is categorised is valuable, as it allows an assessment to be made as to whether the EA 2010's designation of HIV/AIDS as a disability is consistent with relevant international instruments. As detailed, both the ICESR and the ICCPR make no mention of disability or HIV in their non-exhaustive list of protected characteristics. Rather, HIV is deemed capable of falling within the category of 'other status' under both the ICESR ${ }^{241}$ and the ICCPR. ${ }^{242}$ The ILO Code of Practice on HIV/AIDS and the World of Work also does not explicitly define HIV as a disability; however, the Code recommends the use of reasonable accommodation in order to ensure PLHA's continuance in employment. ${ }^{243}$ In the majority of international jurisdictions, the concept of reasonable accommodation is intrinsically linked to disability, which indicates that the ILO implicitly equates HIV with the concept of disability. ${ }^{244}$ This illustrates that there is no consistent approach to the manner in which PLHA are protected by these normative sources at the international level. International Labour Organisation, 'An ILO Code of Practice on HIV/AIDS and the World of Work' (2001 International Labour Organisation).

UN Committee on Economic, Social and Cultural Rights, General Comment No. 18 on the right to work adopted at the thirty-fifth session of the Committee, 2005) UN Doc E/C.12/GC/18, para 12 (b)(i). Office of the High Commissioner for Human Rights, 'Resolution 1995/44 - The protection of human rights in the context of human immunodeficiency virus (HIV) and acquired immune deficiency syndrome (AIDS)' (Doc No E/CN.4/1995/176) 
The final instrument identified was the UN CRPD. The definition of disability contained in Article 1 of the CRPD is broad enough to include HIV or AIDS due to the CRPD's use of the social model of disability. In addition, the UN Office of the High Commissioner for Human Rights, the World Health Organization and UNAIDS have explicitly endorsed the applicability of the CRPD to PLHA. The CRPD is a more significant treaty as, of all the international instruments identified, the CRPD has the ability to indirectly shape the EA 2010's definition of disability due to its designation as one of the Community treaties within the definition of section 1(2) of the European Communities Act 1972. ${ }^{245}$ This means that the provisions of the convention must be given effect to and enforced accordingly. Indeed, when considered from a purely normative perspective, the designation of PLHA as disabled by the EA 2010 appears entirely consistent with the UN CRPD and, indeed, the Act's designation of HIV as a disability removes the inconsistency that has arisen under the ICESR and ICCPR as to whether PLHA should acquire protection from discrimination on the basis of disability, health or other status.

Consideration will now be made of the European Convention on Human Rights, which merits distinct consideration due to its status as a regional, as opposed to global, convention and also its partial incorporation into domestic law by the Human Rights Act 1998.

\subsection{THE EUROPEAN CONVENTION ON HUMAN RIGHTS}

The European Convention on Human Rights was adopted by the newly formed Council of Europe in Rome on 4 November 1950 and protects the human rights of people in countries that belong to the Council of Europe. ${ }^{246}$ Formed in 1949, the Council of Europe is completely independent of both the United Nations and the European Union, although there is substantial overlap in membership of both the Council of Europe and the EU. It is also significantly larger than the European Union, with 47 members compared to the EU's 28 and should the UK leave the EU, its membership of the Council would be unaffected.

The European Convention on Human Rights was signed by the United Kingdom in 1950 and entered into force in 1953. ${ }^{247}$ It was a response to the horrors experienced in Europe during the two world wars and the first comprehensive international human rights treaty. It established an international court dealing exclusively with human rights (the European Court of Human Rights) and also provided for the establishment of a European Commission of Human Rights. The Convention is concerned primarily with violations of its rights and freedoms by public authorities. However, it expressly requires contracting states to ensure that the rights and

\footnotetext{
245 The European Communities (Definition of Treaties) (UN CRPD) Order, SI 2009/1181.

246 Gary Slapper and David Kelly, The English Legal System (16th edn Routledge 2015).

$247 \quad$ ibid.
} 
freedoms contained in the Convention are afforded to everyone within their jurisdiction. The European Convention on Human Rights merits special consideration due to its partial incorporation into domestic law by the Human Rights Act 1998 and, as enunciated by the High Court in Thoburn v Sunderland CC, the Human Rights Act is designed to 'make more directly accessible the rights which British people already enjoy under the Convention' by providing access to those rights through the domestic courts. ${ }^{248}$

The main provisions of the European Convention on Human Rights, which are given effect by the Human Rights Act 1998 are the right to life, ${ }^{249}$ the prohibition of torture, ${ }^{250}$ the prohibition of slavery and forced labour, ${ }^{251}$ the right to liberty and security, ${ }^{252}$ the right to a fair trial, ${ }^{253}$ the right to no punishment without law, ${ }^{254}$ the right to respect for private and family life, ${ }^{255}$ the right to freedom of thought, conscience and religion, ${ }^{256}$ the right to freedom of expression, ${ }^{257}$ the right to freedom of assembly and association, ${ }^{258}$ the right to marry 259 and the prohibition of discrimination in respect of the enjoyment of these rights. ${ }^{260}$

There are two principal mechanisms for giving effect to Convention rights under the Human Rights Act. The first is the interpretative obligation placed upon UK courts by section 3(1) which states:

So far as it is possible to do so, primary legislation and subordinate legislation must be read and given effect in a way which is compatible with the Convention rights.

This interpretative obligation requires all legislation, primary and subordinate, past and future, to be read and given effect so far as possible in a way which is compatible with the Convention rights. Thus, so far as it is possible to do so, primary legislation must be read and given effect in a way which is compatible with the Convention rights. ${ }^{261}$

[2002] EWHC 195, [2003] QB 151.

Article 2.

Article 3.

Article 4.

Article 5.

Article 6.

Article 7.

Article 8.

Article 9.

Article 10.

Article 11.

Article 12.

Article 14.

Ghaidan v Godin-Mendoza [2004] UKHL 30, [2004] 2 AC 557. 
The second principal mechanisms for giving effect to Convention rights is the obligation imposed on all public authorities, including courts, to act compatibly with Convention rights contained at section 6(1) which states:

It is unlawful for a public authority to act in a way which is incompatible with a Convention right.

It has been argued by Wildhaber ${ }^{262}$ and Livingstone ${ }^{263}$ that cases involving discrimination within the employment relationship are excluded from the scope of the European Convention on Human Rights as the relationship does not fall within the scope of the substantive freestanding Convention rights. The exclusion of private employment is also reinforced by the fact that the only permissible defendants before the European Court of Human Rights are national authorities; however, domestic courts are not restricted in this manner. Yet this argument is too broad as the European Court of Human Rights acknowledged in the case of Smith and Grady $v$ United Kingdom. ${ }^{264}$ There the court held that Article 8 of the Convention precludes dismissal from military employment on the grounds of sexual orientation. Further Wintemute argues that Article 14 covers employment discrimination against an individual based on, for example, their religion, political opinion, sexual orientation or gender identity because the ground falls 'within the ambit' of freedom of religion, freedom of expression, assembly and association, or respect for private life, even though the opportunity (i.e. employment) does not. ${ }^{265}$ This argument appears to have carried favour with the courts as there are numerous examples of the Convention being used with varying degrees of success by applicants to demonstrate the applicability of human rights to the employment relationship. ${ }^{266}$ It is also readily apparent that an individual's HIV status is considered a private matter, and thus any attempt to ascertain this within the employment relationship through, for example, pre-employment health questionnaires or blood tests, may constitute a breach of the right to respect an individual's private life.

The application of the European Convention on Human Rights to PLHA and the field of disability discrimination is also, on the face of it, dubious when one examines the relevant Article. Article 14 states:

Judge L Wildhaber, 'Protection against Discrimination under the European Convention on Human Rights - A Second Class Guarantee' (2002) 2 Baltic Yearbook of International Law 71.

S Livingstone, 'Article 14 and the prevention of discrimination in the European Convention on Human Rights' (1997) 1 European Human Rights Law Review 25. [2000] ECHR 383

R Wintemute, 'Within the ambit": how big is the "gap" in Article 14 European Convention on Human Rights?' (2004) 4 European Human Rights Law Review 366.

See for example Redfearn v United Kingdom [2012] ECHR 1878, Eweida v the United Kingdom [2013] ECHR 285, Bărbulescu v. Romania App no 61496/08 (ECtHR 5 September 2017).
} 
The enjoyment of the rights and freedoms set forth in this Convention shall be secured without discrimination on any ground such as sex, race, colour, language, religion, political or other opinion, national or social origin, association with a national minority, property, birth, or other status.

Article 14 therefore does not create a free standing right from discrimination. Instead, it requires contracting states to ensure that the Convention rights are secured without discrimination. Thus, in order for Article 14 to be engaged, the claimant must show that the act in question comes within the ambit of a Convention right and that there has been discrimination in the treatment afforded to him. Even if these elements are established, the question of justification arises before the discrimination can be considered unlawful. ${ }^{267}$ However, Article 1 of (optional) protocol 12 to the Convention which opened for signature in 2000 seeks to convert Article 14 into a freestanding right against protection without the need for any other Convention Article to be engaged. It states:

The enjoyment of any right set forth by law shall be secured without discrimination on any ground such as sex, race, colour, language, religion, political or other opinion, national or social origin, association with a national minority, property, birth, or other status.

The United Kingdom has, however, so far refused to sign protocol 12 and until it does so, domestic courts must apply the unamended Article 14.

Whilst the grounds upon which Article 14 prohibits discrimination are extensive, neither disability or HIV status are explicitly mentioned. However, the use of wording 'or other status' illustrates that the grounds identified are by way of example only and not exhaustive. This consequently provides scope for extending the scope of the Article. The term 'other status' has not been defined but has been held to be capable of encompassing disability in the case of Glor $v$ Switzerland. ${ }^{268}$ The decision in Glor was made shortly after the coming into force of the United Nations CRPD and reference was made to the CRPD itself and the fact in the court's opinion that, 'there is a European and worldwide consensus on the need to protect people with disabilities from discriminatory treatment' ${ }^{269}$ It was also noted that, 'the margin of appreciation the States enjoy in establishing different legal treatment for people with disabilities is considerably reduced. ${ }^{270}$

See for example the approach taken in Petrovic v Austria (2001) 33 EHRR 14.

Glor v. Switzerland 2009-III 33.

Glor v. Switzerland 2009-III 33, para 53.

ibid, para 84. 
Moving from disability to HIV status, the case of Kiyutin v. Russia raised the question as to whether HIV falls within the remit of Article $14 .{ }^{271}$ In this case, the applicant was a national of Uzbekistan who lived in Russia and was married to a Russian national with whom he had a young child. Kiyutin's application for a residence permit was rejected by the Russian authorities on account of his HIV status. According to Russian legislation, foreigners wishing to remain in the country indefinitely must demonstrate that they are HIV-negative. In his application to the European Court of Human Rights, Kiyutin argued that the rejection of his application for a residency permit violated his right to respect for his family life as well as his right to nondiscrimination on the basis of HIV status, i.e. Article 14 in conjunction with Article 8, that is his right to respect for his private and family life.

Interights, a third-party intervener in the case, submitted that the general non-discrimination provisions of key human rights treaties were interpreted as prohibiting discrimination on the basis of HIV or AIDS status, actual or presumed and that such an approach had been adopted by various United Nations Committees. ${ }^{272}$ In addition, reference was made to the fact that member States of the United Nations had set out their commitment to adopt and enforce legislation aimed at eliminating all forms of discrimination against PLHA in the Declaration of Commitment on HIV/AIDS ${ }^{273}$ adopted by the United Nations General Assembly in August 2001.274

Interights also submitted that, in addition to these general anti-discrimination standards, PLHA 'should benefit from the prohibition of discrimination on account of disability existing in the court's case-law and in other legal systems. ${ }^{275}$ To support this argument, reference was made to the fact that the United Nations Office of the High Commissioner for Human Rights, the World Health Organization and UNAIDS endorsed the applicability of the disability antidiscrimination framework of the United Nations CRPD to PLHA in their joint report 'Disability and HIV policy brief'. ${ }^{276}$ Finally, it was put forward that a number of countries, including the UK, had 'expressly or implicitly extended their disability laws to include HIV status'.277

On 10 March 2011, the European Court of Human Rights held that refusing a residence permit to a foreign national solely on the basis of their HIV-positive status amounted to unlawful discrimination. The judgment then became final on 15 September 2011 as a five-judge panel of the Grand Chamber rejected the Russian government's request for referral. Consequently, the

Kiyutin v. Russia app no 2700/10 (ECtHR, 10 March 2011).

ibid, para 46

United Nations, 'Declaration of Commitment on HIV/AIDS' (United Nations 2001).

Kiyutin v. Russia App no 2700/10 (ECtHR, 10 March 2011), para 46.

ibid, para 47.

UNAIDS, WHO and OHCHR, Disability and HIV Policy Brief (United Nations 2009) <www.who.int/disabilities/jc1632_policy_brief_disability_en.pdf> accessed 23 November 2017.

Kiyutin v. Russia App no 2700/10 (ECtHR, 10 March 2011), para 47. 
court explicitly recognised that PLHA are capable of being protected as a distinct group against discrimination in relation to their fundamental rights. The court stated:

Although Article 14 does not expressly list a health status or any medical condition among the protected grounds of discrimination, the Court has recently recognised that a physical disability and various health impairments fall within the scope of this provision. The Court notes the view of the UN Commission on Human Rights that the term "other status" in non-discrimination provisions in international legal instruments can be interpreted to cover health status, including HIV-infection...Accordingly, the Court considers that a distinction made on account of one's health status, including such conditions as HIV infection, should be covered - either as a form of disability or alongside with it - by the term "other status" in the text of Article 14 of the Convention. ${ }^{278}$

Second, it recognised that PLHA are a vulnerable group and any restriction of their rights attracts a higher degree of scrutiny on the part of the European Court of Human Rights. Therefore, the State should be afforded only a narrow margin of appreciation in choosing measures that single out this group for differential treatment on the basis of their HIV status. Thus the court stated:

From the onset of the epidemic in the 1980s, people living with HIV/AIDS have suffered from widespread stigma and exclusion...In the early years of the epidemic when HIV/AIDS diagnosis was nearly always a lethal condition and very little was known about the risk of transmission, people were scared of those infected due to fear of contagion. Ignorance about how the disease spreads has bred prejudices which, in turn, has stigmatised or marginalised those who carry the virus. As the information on ways of transmission accumulated, HIV infection has been traced back to behaviours - such as same-sex intercourse, drug injection, prostitution or promiscuity - that were already stigmatised in many societies, creating a false nexus between the infection and personal irresponsibility and reinforcing other forms of stigma and discrimination, such as racism, homophobia or misogyny...The Court therefore considers that people living with HIV are a vulnerable group with a history of prejudice and stigmatisation and that the State should be afforded only a narrow margin of appreciation in choosing measures that single out this group for differential treatment on the basis of their HIV status. ${ }^{279}$ 
Whilst the judgment is to be welcomed, the somewhat vague language of paragraph 57 means that it remains to be seen whether PLHA will benefit from the protection of Article 14 on the ground of their HIV status alone or will instead have to argue that they are disabled. The Kuyitin judgment also raises the possibility that health status is now one of the grounds afforded protection by Article 14 but does not offer clarity as to where HIV positions itself in relation to these grounds. By way of example, it is unclear whether HIV should be perceived as a sub-set of health status or of disability. There is also the alternative possibility that HIV should be afforded protection as of its own right. Whilst in addition to this, Peroni and Timmer raise the possibility that the decision in Kiyutin demonstrates that the court is developing the concept of membership of a vulnerable group as a protected group under Article $14 .^{280}$ The increasing significance of vulnerability as a protected characteristic is also accepted by Arnardóttir. ${ }^{281}$ Indeed, comments made by the court in the case of Guberina v Croatia ${ }^{282}$ do appear to illustrate a willingness on the court's part to continue the development of membership of a vulnerable group as a protected group. There the court noted that:

...if a restriction on fundamental rights applies to a particularly vulnerable group in society that has suffered considerable discrimination in the past, then the State's margin of appreciation is substantially narrower and it must have very weighty reasons for the restrictions in question. The reason for this approach, which questions certain classifications per se, is that such groups were historically subject to prejudice with lasting consequences, resulting in their social exclusion. Such prejudice could entail legislative stereotyping which prohibits the individualised evaluation of their capacities and needs. The Court has already identified a number of such vulnerable groups that suffered different treatment on account of their characteristic or status, including disability (see Glor, cited above, § 84; Alajos Kiss v. Hungary, no. 38832/06, $\S 42,20$ May 2010; and Kiyutin v. Russia, no. 2700/10, § 63, ECHR 2011). ${ }^{283}$

In a later decision of the European Court of Human Rights, I.B. v. Greece ${ }^{284}$, the Court did not unfortunately clarify the exact manner in which PLHA are capable of being protected under the Convention but underlined how seriously it treats discrimination against PLHA. In this case the applicant, I.B., was a Greek national who had been working since 2001 in a company which manufactured jewellery. In January 2005, he confided to three of his fellow employees that he

L Peroni and A Timmer, 'Vulnerable groups: The promise of an emerging concept in European Human Rights Convention law' (2013) 11 (4) International Journal of Constitutional Law, 1056. 
was afraid he had contracted HIV. These three colleagues then wrote a letter to the director of the company stating that I.B. had AIDS and that the company ought to dismiss him. Following this, information about I.B.'s health began to circulate around the company and I.B. stated that he was stigmatised by his fellow employees and treated like a pariah. On 10th February, I.B. tested positive for HIV and the employer invited an occupational health doctor to come and speak to the employees to reassure them that there was no risk whatsoever to their own health. Despite this, on 21 st February, 33 of I.B.'s fellow employees sent a letter to the director of the company demanding his dismissal in order 'to safeguard their health and their right to work' ${ }^{285}$ Two days later, I.B. was fired by the company.

The first national Court held that I.B.'s dismissal was illegal. The national court of appeal also held that his dismissal was illegal. However, the Greek Court of Cassation quashed that judgment deciding that his termination was justified in order to ensure the smooth functioning of the company and harmonious relations within it. Subsequently, I.B. complained to the European Court of Human Rights that his dismissal violated his right to private life under Article 8 in conjunction with the prohibition of discrimination under Article 14.

The European Court of Human Rights decided that Article 8 was engaged as I.B.'s dismissal, and the stigma to which he had been subjected, was bound to have serious repercussions for his private life. During the course of its judgment, the Court made reference to both the ILO Code of Practice on HIV/AIDS and the World of Work ${ }^{286}$ and the ICESR. ${ }^{287}$ The Court noted that, 'of thirty member states of the Council of Europe, with regard to protection against discrimination in the workplace given to people with HIV ...seven states, namely Albania, Azerbaijan, Italy, Moldova, Romania, the United Kingdom and Russia have adopted specific legislation in this regard. ${ }^{288}$ By contrast, in the remaining member States, the Court noted that PLHA have relied on the relevant general non-discrimination principle contained in domestic law and to support this several examples were provided:

40. In France, for example, on 6 September 2012 the Equal Treatment Commission (the Human Rights Council since October 2012) found that the Law on equal treatment of persons suffering from a disability or chronic illness did not oblige an employee (the case in question concerned the dismissal of an HIV-positive employee of a licensed bar) to disclose his or her illness unless he or she would otherwise be unable to perform the work. The Commission also found that the supposed prejudice of customers towards HIV-positive persons did not justify terminating the contract.

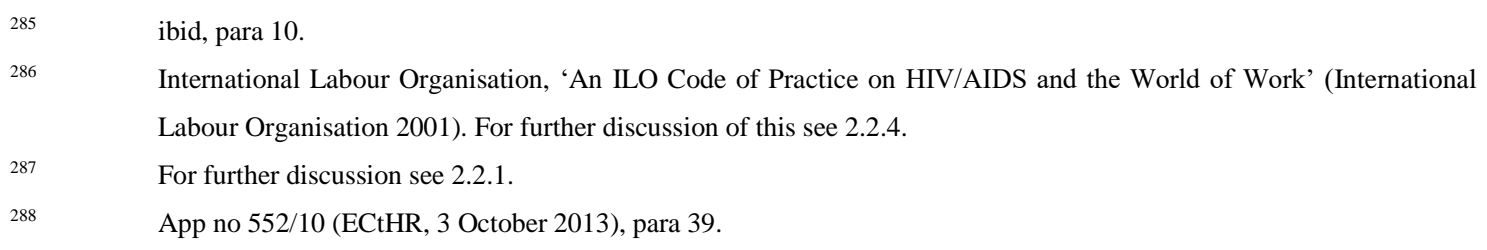


41. On 13 December 1995 the Pontoise Criminal Court, in France, sentenced an employer to five months' imprisonment, suspended, and ordered him to pay EUR 3,000 in damages for dismissing - purportedly on economic grounds - one of his employees, a veterinary assistant who was HIV-positive.

42. Even before the enactment in Belgium of the Law of 10 May 2007 on combating certain forms of discrimination, the Dendermonde Labour Court had held, on 5 January 1998, that an employer had abused his right to terminate an employment contract by dismissing an employee solely on account of his HIV infection.

43. The Swiss Federal Supreme Court (judgment BGE 127 III 86) held that dismissal from work solely on account of HIV infection was discriminatory and unfair for the purposes of Article 336 of the Code of Obligations.

44. On 18 October 2004 the Poltava Regional Court, in Ukraine, ordered the editor of a newspaper to pay compensation to a journalist who had been dismissed because he was HIV-positive.

45. In Croatia, following the intervention of the Ombudsman, the Police Internal Rules, which had previously provided that an HIV-positive person could neither become nor remain a serving police officer, were amended.

46. On 23 November 2009 the Polish Constitutional Court declared unconstitutional a provision of the Ministry of Interior's Regulations according to which any police officer who was HIV-positive should automatically be declared unfit for service.

47. On 26 April 2011 the Russian Supreme Court declared inoperative a provision of the Civil Aviation Regulations forbidding HIV-positive persons from working as pilots on any type of aircraft. ${ }^{289}$

No explicit mention was made to the United Nations CRPD as there was in the Kiyutin 290 judgment. However, the Court referred to its earlier decision in Kiyutin and stressed that when vulnerable groups like PLHA were treated differently, states would only be afforded a very narrow margin of appreciation. Here, the treatment of I.B. fell outside that margin of appreciation and accordingly his human rights had been breached. As Danisi puts it, the 'other employees' interests and the necessity to ensure a pleasant working environment could not

ibid, paras $40-47$.

App no 2700/10 (ECtHR, 10 March 2011). 
exceed the "human right-based interest" to maintain the vulnerable position of employees living with HIV/AIDS. ${ }^{291}$ This decision, together with the earlier decision in Kiyutin, makes it clear that PLHA are unquestionably protected by Article 14 and viewed very much as a vulnerable group by the European Court of Human Rights.

\subsubsection{CONCLUSION}

It has already been noted in section 3.2.6 that there is no consistent approach to the manner in which PLHA are protected by normative sources at the international level. This is a trend which continues under the European Convention on Human Rights. Thus, although in both Kiyutin v Russia ${ }^{292}$ and I.B. v Greece ${ }^{293}$ PLHA were found to be capable of falling with Article 14, what is striking in both cases is the lack of clarity as to the precise manner in which PLHA should be protected from discrimination.

The decision in Kiyutin failed to demonstrate whether PLHA should be protected by the term 'other status' on the basis of their health status, disability or indeed HIV infection alone. The court in Kiyutin also clouded the issue by citing PLHA's membership of a vulnerable group at one point in their judgment, an area that some academics argue the European Court is gradually introducing as a distinct group worthy of protection. ${ }^{294}$ The later decision of I.B. also failed to offer clarification merely noting instead that people living with HIV were a vulnerable group and thus worthy of protection from discrimination.

However, despite this confusion, there was an acknowledgement in Kiyutin of the existence of there being a link between HIV and disability. Indeed, the fact that the joint report, Disability and HIV Policy Brief was cited by the court signals that possibility that the European Court of Human Rights views HIV as akin to a disability. ${ }^{295}$ This joint report of the United Nations Office of the High Commissioner for Human Rights, World Health Organization and UNAIDS, endorses the applicability of the CRPD and its disability anti-discrimination framework to PLHA. The use of such an approach, whilst clearly according with the United Nations CRPD, also demonstrates that the EA 2010's designation of HIV as a disability is consistent with the

C Danisi, 'Protecting the Human Rights of People living with HIV/AIDS: A European Approach?' (2015) 3 (2) Groningen Journal of International Law 47, 59.

App no 2700/10 (ECtHR, 10 March 2011).

App no 552/10 (ECtHR, 3 October 2013).

L Peroni and A Timmer, 'Vulnerable groups: The promise of an emerging concept in European Human Rights Convention law' (2013) 11 (4) International Journal of Constitutional Law, 1056; O Arnardóttir, 'Vulnerability under Article 14 of the European Convention on Human Rights. Innovation or Business as Usual?' (2017) 4 Oslo Law Review 3.

UNAIDS, WHO and OHCHR, Disability and HIV Policy Brief (United Nations 2009) <www.who.int/disabilities/jc1632_policy_brief_disability_en.pdf> accessed 23 November 2017. 
approach taken by the European Court of Human Rights. However, again the EA 2010's clear designation of HIV as a disability removes the ambiguity that has developed at the European Court of Human Rights despite the passage of just two cases concerning the protection of PLHA, namely Kiyutin and I.B.

Consideration will now be made of European Union normative sources in this area, specifically the Framework Directive and the decisions of the Court of Justice of the European Union relating to the same.

\subsection{EUROPEAN UNION LAW}

As will be demonstrated, European Union (EU) discrimination measures have been of increasing significance in recent years. The motivation behind the creation of the EU was the consolidation of European economies, particularly France and Germany, following World War Two in order to attempt to prevent future hostilities. ${ }^{296}$ The UK joined the European Economic Community in 1973 and the European Union was joined following its inception at the signing of the Maastricht Treaty in 1993. The treaty was then later renamed as the Treaty on the Functioning of the European Union (TFEU) with the coming into force of the Treaty of Lisbon in 2009. In the wake of the referendum on the UK's membership of the EU, ${ }^{297}$ it is anticipated that the UK will formally leave the EU in 2019. ${ }^{298}$ However, it has been confirmed by the Government that after the UK's departure from the EU, legislation implementing EU obligations in domestic law will be introduced with the effect that they will continue in force at the domestic level unless and until amended or repealed by UK legislative action. ${ }^{299}$

Article 19 of the $\mathrm{TFEU}^{300}$ provides:

Without prejudice to the other provisions of the Treaties and within the limits of the powers conferred by them upon the Union, the Council, acting unanimously in accordance with a special legislative procedure and after obtaining the consent of the European Parliament, may take appropriate action to combat discrimination based on sex, racial or ethnic origin, religion or belief, disability, age or sexual orientation.

\footnotetext{
296 See for example T Judt, Postwar - A history of Europe since 1945, (Penguin 2005), 117.

297 The Electoral Commission, 'EU referendum results' (15 August 2016) < https://www.electoralcommission.org.uk/findinformation-by-subject/elections-and-referendums/past-elections-and-referendums/eu-referendum/electorate-andcount-information> accessed 14 December 2017.

298 P McClean, 'Brexit timeline: key dates in UK's divorce with EU' Financial Times (London, 14 June 2017)

299 Department for Exiting the European Union, The United Kingdom's exit from, and new partnership with, the European Union (White Paper, Cm 9417, 2017) ch 1.

300 Article 13 of the former EC Treaty was the first reference to disability in Treaty for the purposes of European Law.
} 
There is thus neither explicit mention of HIV status in the TFEU nor any opportunity to expand the closed list of prohibited grounds. Yet in spite of this, the European Union has committed itself to combating discrimination against PLHA. The Dublin Declaration of 2004 entitled 'Partnership to Fight HIV/AIDS in Europe and Central Asia' commits member states to 'combat stigma and discrimination of people living with HIV/AIDS in Europe and Central Asia, including through a critical review and monitoring of existing legislation, policies and practices with the objective of promoting the effective enjoyment of all rights for people living with HIV/AIDS and members of affected communities. ${ }^{301}$

This is reaffirmed in the Vilnius Declaration of 2004 where there is a commitment on the part of member states to 'continue to develop and implement relevant legislation, in particular with a view to prohibiting discrimination, inter alia in employment, on the grounds of HIV status. ${ }^{302}$ Similar concerns were expressed in the Bremen Declaration of $2007^{303}$ and again, in 2009, in a Communication from the Commission to the European Parliament, the Council, the European Economic and Social Committee and the Committee of the Regions, the European Commission noted:
After three decades of HIV/AIDS there is still no room for complacency. The best response to the epidemic remains a combination of health specific and wider social interventions. People will continue to suffer unless prevention is accelerated and universal access to treatment, care and support is ensured for all people in need. ${ }^{304}$

Despite these commitments, discrimination provisions in EU law fail to explicitly include HIV status. The consequence of this is that member states are free to choose either to protect or not to protect PLHA from discrimination and, if PLHA are to be protected from discrimination at the EU level, PLHA must argue that HIV amounts to a disability.

Due to the scope of Directives adopted in order to combat discrimination within the EU, protection from discrimination on the grounds of disability is less far reaching than protection

\footnotetext{
301 Dublin Declaration, 'Partnership to fight HIV/AIDS in Europe and Central Asia' (2004) <https://www.unicef.org/eca/ru/Dublin_AIDS_Conference_Breaking_the_Barriers.pdf > accessed 9 May 2018

302 'Vilnius Declaration' on Measures to Strengthen Responses to HIV/AIDS in the European Union and in Neighbouring Countries < http://ec.europa.eu/health/ph_threats/com/aids/docs/ev_20040916_rd03_en.pdf> accessed 20 November 2017.

Bremen Declaration of 2007 on Responsibility and Partnership- Together Against HIV/AIDS. The text of the declaration is available via <http://www.aidsactioneurope.org/sites/default/files/bremen_declaration.pdf $>$ accessed 24 November 2017. 
from discrimination in relation to other grounds. ${ }^{305}$ By way of example, the Racial Equality Directive $^{306}$ protects individuals from discrimination upon the ground of racial and ethnic origin in a number of fields including employment, social protection, social advantages, education and access to and supply of goods and services. In addition, the Gender Goods and Services Directive was introduced in order to expand the scope of equality on the grounds of gender to goods and services ${ }^{307}$. However, protection from discrimination on the grounds of disability is more restricted in scope due to the fact that Article 3 of the Framework Directive only provides protection against discrimination in the sphere of employment, vocational guidance and training, and membership of professional, workers' and employers' bodies. ${ }^{308}$ On 2 July 2008 , the European Commission adopted a proposal for a new directive on discrimination applicable to inter alia the provision of goods, services and facilities, which includes disability. ${ }^{309}$ In addition, on 2 December 2015, the European Commission published a draft Directive 2015/0278 described as the European Accessibility Act, which would introduce a duty to ensure that certain products and services were accessible for all regardless of age or disability. However, currently both are still proposals which will need the consent of all member states to be adopted as law.

The Framework Directive provides minimum requirements that have to be implemented by Member States. Article 2(1) provides:

For the purposes of this Directive, the principle of equal treatment shall mean that there shall be no direct or indirect discrimination whatsoever on any of the grounds referred to in Article 1.

For further commentary and analysis see R Whittle, R ‘Disability Discrimination and the Amsterdam Treaty’ (1998) 23 European Law Review 50; M Bell, 'Article 13 EC: The European Commission's Anti-discrimination proposals' (2000) 29 Industrial Law Journal 79; D Mabbett, 'The Development of Rights-based Social Policy in the European Union: The Example of Disability Rights' (2005) 43 Journal of Common Market Studies 97.

Council Directive 2000/43/EC of 29 June 2000 implementing the principle of equal treatment between persons irrespective of racial or ethnic origin [2000] OJ L 180/22.

Council Directive 2004/113/EC of 13 December 2004 implementing the principle of equal treatment between men and women in the access to and supply of goods and services [2004] OJ L 373/37.

For commentary of the Framework Directive see for example P Skidmore, 'EC framework employment directive on equal treatment in employment: towards a comprehensive community anti-discrimination policy?’ (2001) 30 Industrial Law Journal 126; S Fredman, 'Equality: a new generation?’ (2001) 30 Industrial Law Journal 145; L Waddington and M Bell, 'More equal than others: distinguishing European Union equality directives' (2001) 38 Common Market Law Review 587-611; M Bell and L Waddington, 'Reflecting on inequalities in European Community equality law' [2003] European Law Review 349.

Council of the European Union, 'Proposal for a Council Directive on implementing the principle of equal treatment between persons irrespective of religion or belief, disability, age or sexual orientation - Progress Report' (Council of the European Union 2012). 
The grounds referred to in Article 1 are religion or belief, disability, age and sexual orientation. In addition, harassment is prohibited as a consequence of Article 2(3) and a duty to make reasonable accommodation is contained in Article 5.

It should be noted that the Framework Directive must be interpreted in a manner consistent with the Charter of Fundamental Rights of the European Union. Of greatest importance are Article 20 which provides, 'Everyone is equal before the law' and Article 21(1) which provides:

Any discrimination based on any ground such as sex, race, colour, ethnic or social origin, genetic features, language, religion or belief, political or any other opinion, membership of a national minority, property, birth, disability, age or sexual orientation shall be prohibited.

Finally, Article 26 which states that:

The Union recognises and respects the right of persons with disabilities to benefit from measures designed to ensure their independence, social and occupational integration and participation in the life of the community.

In addition, as the EU ratified the United Nations CRPD, ${ }^{310}$ international agreements concluded by the EU are binding upon the institutions of the EU and the CRPD represents part of the EU legal order. ${ }^{311}$ Indeed, in HK Danmark (Ring and Skouboe Werge) ${ }^{312}$ the CJEU reaffirmed that:

28 It should be noted, as a preliminary point, that, by virtue of Article 216(2) TFEU, where international agreements are concluded by the European Union they are binding on its institutions, and consequently they prevail over acts of the European Union (Case C-366/10 Air Transport Association of America and Others [2011] ECR I-13755, paragraph 50 and the case-law cited).

29 It should also be recalled that the primacy of international agreements concluded by the European Union over instruments of secondary law means that those instruments must as far as possible be interpreted in a manner that is consistent with those agreements (Joined Cases C-320/11, C-330/11, C-382/11 and C-383/11 Digitalnet and Others [2012] ECR, paragraph 39 and the case-law cited). 
30 It follows from Decision 2010/48 that the European Union has approved the UN

Convention. The provisions of that convention are thus, from the time of its entry into force, an integral part of the European Union legal order (see, to that effect, Case 181/73 Haegeman [1974] ECR 449, paragraph 5).

As such the Framework Directive must be interpreted in a manner consistent with the United Nations CRPD.

\subsubsection{THE DEFINITION OF DISABILITY UNDER THE FRAMEWORK DIRECTIVE}

Rather unsatisfactorily, the Framework Directive provides no definition of disability. ${ }^{313}$ Indeed, commonly, EU discrimination Directives provide little guidance on the definition of the relevant protected characteristics. ${ }^{314}$ This has the potential to permit multiple varying definitions of disability to be adopted across the EU and for different domestic member courts to adopt differing approaches as to whether a particular impairment constitutes a 'disability'. ${ }^{315}$ These '[d]isparities in definitions cause inequalities for some groups and undermine their right to freedom of movement as enshrined in the EU Treaties'. ${ }^{316}$ As the House of Lords Select Committee on the European Union noted when discussing the draft Framework Directive:

The Commission's view that definitions of key concepts can simply be "left to Member States" is an over-simplification. EU-wide definitions will evolve as cases reach the Court of Justice. This will be a long process, and there will inevitably be a period of uncertainty as cases are taken through the courts. ${ }^{317}$

In the case of Chacon Navas $v$ Eurest Colectividades $\mathrm{SA}^{318}$ the Court of Justice of the European Union (CJEU) offered guidance on the issue stating that, "the concept of "disability" must be understood as referring to a limitation which results in particular from physical, mental or psychological impairments and which hinders the participation of the person concerned in

The Dutch and Belgian legislation implementing the Framework Directive also contain no definition of disability. For further discussion of the approach taken by these jurisdictions see L Waddington, 'Implementing the Disability Provisions of the Employment Framework Directive' in A Lawson and C Gooding (eds), Disability Rights in Europe: From theory to practice (Hart 2005), 119.

L Waddington, 'Implementing the Disability Provisions of the Employment Framework Directive' in A Lawson and C Gooding (eds), Disability Rights in Europe: From theory to practice (Hart 2005); D Schiek, 'Intersectionality and the Notion of Disability in EU discrimination law' (2016) 53 (1) Common Market Law Review 35. 
professional life. ${ }^{319}$ At the outset of this discussion, it must be stressed that EU law does not have a doctrine of binding precedent such as that possessed by common law jurisdictions. Therefore, as decided in Wünsche Handelsgesellschaft GmbH \& Co. v Federal Republic of Germany, a judgment of the CJEU in a preliminary reference procedure is binding only on the national court that submitted the question. ${ }^{320}$ Nevertheless, in the case of Merck $v$ Primecrown although Advocate General Fennelly stated that 'as a matter of principle, the Court is of course not bound by its own previous judgments'; he added, 'it is none the less obvious that the Court should, as a matter of practice, follow its previous case-law except where there are strong reasons for not so doing., 322

Importantly in Chacon Navas, the CJEU held that workers do not fall within the scope of the protection afforded by the Framework Directive as soon as they develop any type of sickness and so made an important distinction between sickness and disability. ${ }^{323}$ In addition, it was strongly stated that sickness cannot be regarded as a separate prohibited ground of discrimination for the purposes of the Framework Directive. It was against this backdrop that judgment in the case of HK Danmark (Ring and Skouboe Werge) was delivered by the CJEU. ${ }^{324}$ In HK Danmark (Ring and Skouboe Werge), Danish legislation permitted businesses to dismiss those who had been absent due to illness for a certain number of days with only one month's notice, shorter than the notice normally required under Danish employment law. The case was brought by two applicants one of whom, Ms Ring, had developed back pain. The second applicant, Ms Werge, had whiplash following a road accident. Crucially, both applicants were still able to work but were unable to work on a full-time basis. The applicants argued that they had a disability and that this reduced notice period was unlawful disability discrimination, in breach of the EU Framework Directive. A question of fundamental importance was whether or not they fell within the definition of disability as expounded by the Chacon Navas case. The employers disputed that the applicants' state of health was covered by the concept of disability within the meaning of the Framework Directive since the only incapacity that affected them was that they were now not able to work full-time. As such, it was argued by the employers that as they could work part-time they were not excluded completely from participating in professional life and so fell outside the scope of the Framework Directive. The employer's central argument was that the Framework Directives concept of disability, as constructed by the decision in Chacon Navas, implies a complete exclusion from work or professional life as opposed to the partial exclusion here.

Ibid, [43].

Case C-69/85 [1986] EC.R 947, [13].

ibid, [142].

L Waddington, 'HK Danmark (Ring and Skouboe Werge), interpreting EU equality law in light of the UN Convention on the Rights of Persons with Disabilities' (2013) 17 European Anti-discrimination Law Review, 11.

Joined Cases C-335/11 and C-337/11, [2013] 3 CMLR 21. 
The CJEU disagreed, noting that:

The UN Convention, which was ratified by the European Union by decision of 26 November 2009, in other words after the judgment in Chacón Navas had been delivered, acknowledges in recital (e) that 'disability is an evolving concept and that disability results from the interaction between persons with impairments and attitudinal and environmental barriers that hinders their full and effective participation in society on an equal basis with others'. Thus the second paragraph of Article 1 of the convention states that persons with disabilities include 'those who have long-term physical, mental, intellectual or sensory impairments which in interaction with various barriers may hinder their full and effective participation in society on an equal basis with others'. ${ }^{325}$

After referring explicitly to the UN CRPD the CJEU stated:

the concept of 'disability' must be understood as referring to a limitation which results in particular from physical, mental or psychological impairments which in interaction with various barriers may hinder the full and effective participation of the person concerned in professional life on an equal basis with other workers. ${ }^{326}$

It did not, however, overrule the Chacon Navas decision, rather it decided that the, 'circumstance that the person concerned can work only to a limited extent is not an obstacle to that person's state of health being covered by the concept of "disability" and that "a disability" does not necessarily imply complete exclusion from work or professional life.' ${ }^{327}$

The consequence of this is that the impairment does not have to completely hinder or exclude an individual from participation in professional life but rather be one which may hinder full and effective participation in professional life. As the ratification of the United Nations CRPD by the $\mathrm{EU}^{328}$ followed the Chacon Navas decision, it clearly follows from Article 216(2) TFEU that international agreements concluded by the EU are binding upon the institutions of the EU. As such, the Directive must be interpreted in a manner consistent with the United Nations CRPD, and the concept of disability within the meaning of the Framework Directive should not fall short of the scope of the protection afforded by the UN CRPD. ${ }^{329}$

ibid, [37].

ibid, [38].

ibid, [43].

Council Decision of 26 November 2009 concerning the conclusion, by the European Community, of the United Nations Convention on the Rights of Persons with Disabilities (2010/48/EC) OJ L 23/35. 
In what may be of some comfort to PLHA the CJEU stated, 'it does not appear that Directive $2000 / 78$ is intended to cover only disabilities that are congenital or result from accidents, to the exclusion of those caused by illness. ${ }^{330}$ Indeed were it to do so it, 'would run counter to the very aim of the directive, which is to implement equal treatment'. ${ }^{331}$ Yet, even though $H K$ Danmark (Ring and Skouboe Werge) appears to lower the bar, it is questionable whether PLHA will fulfil the CJEU's conceptual requirement of disability at the point of their diagnosis, due to the progressive nature of the condition. To quote McTigue:

If a purely functional approach to the question of 'participation in professional life' is taken, then the majority of PLHA face no functional or imitational barriers to participation in professional life. They can, to the naked eye, participate on exactly the same terms and meet the same functional requirements as fellow professionals without HIV. Unlike wheelchair users, they are not disabled by any physical features of their employer's premises, for example, steps or heavy doors. However, at the point of diagnosis, stigma and the fear of discrimination combine to significantly hinder the full and effective participation of PLHA in professional life on an equal basis with their fellow workers. ${ }^{332}$

Interestingly, the issues of whether HIV could amount to a disability and whether a minimum level of severity is required before an impairment can be considered a disability were touched upon by the Advocate General in HK Danmark (Ring and Skouboe Werge). Advocate General Kokott stated:

The distinction between sickness and disability is therefore easier to draw in these cases than in the case on which the Supreme Court of the United States of America had to rule, where it held that even an asymptomatic HIV infection may constitute a disability within the meaning of the ADA $1990 . .^{333}$

The decision referred to by the Supreme Court of the United States is that of Bragdon v. Abbott. ${ }^{334}$ In this case, the claimant, Abbott, disclosed to her dentist that she was HIV positive prior to requiring treatment in order to fill a cavity. Abbott's dentist refused to treat her in his office and instead offered to treat her at a hospital where she would be responsible for the increased costs associated with the use of hospital treatment. Abbott argued that this treatment

Joined Cases C-335/11 and C-337/11, [2013] 3 CMLR 21, [40].

ibid, [40].

Peter McTigue, 'From Navas to Kaltoft: The European Court of Justice's evolving definition of disability and the implications for HIV-positive individuals' (2015) 15 (4) International Journal of Discrimination and the Law $241,248$. HK Danmark (Ring and Skouboe Werge) Joined Cases C-335/11 and C-337/11, [2013] 3 CMLR 21, [34]. 524 U.S. 624 (1998). 
contravened the Americans with Disabilities Act 1990 (ADA 1990), and the key legal issue for the Supreme Court was whether PLHA fell within the definition of disability under the ADA 1990. The ADA 1990 defines disability at section 1202 as:

(A) a physical or mental impairment that substantially limits one or more of the major life activities of such individual; (B) a record of such an impairment; or (C) being regarded as having such an impairment.

The Supreme Court decided that PLHA did fall within the definition of disability for the purposes of the ADA 1990 as the virus substantially limited one of Bragdon's major life activities. The ADA 1990 contains no definition of what constitutes a 'major life activity' but after referring to medical evidence, the Court concluded that HIV substantially limited Bragdon's ability to reproduce, which they considered a major life activity. Chief Justice Rehnquist, Justice Scalia and Justice Thomas dissented with the majority of the courts on this point, considering reproduction not to be a major life activity. In the Supreme Court's opinion:

The Act addresses substantial limitations on major life activities, not utter inabilities. Conception and childbirth are not impossible for an HIV victim but, without doubt, are dangerous to the public health. This meets the definition of a substantial limitation. The decision to reproduce carries economic and legal consequences as well. There are added costs for antiretroviral therapy, supplemental insurance, and long-term health care for the child who must be examined and, tragic to think, treated for the infection. The laws of some States, moreover, forbid persons infected with HIV from having sex with others, regardless of consent. ${ }^{335}$

With the facts of Bragdon $v$ Abbott in mind, it must be questioned whether PLHA will be able to fall within the definition of disability developed by the CJEU in HK Danmark (Ring and Skouboe Werge). Bragdon was able to persuade the Supreme Court that she should fall within the remit of the ADA, as HIV substantially limited one of her major life activities, her ability to reproduce. Yet clearly a restriction on one's ability to reproduce does not hinder the participation of an individual in professional life as required by the CJEU's functional conception of disability. This is where the concept of disability advanced by the CJEU differs markedly from that employed by the ADA as evidenced by the CJEU's later decision in Z. v. A Government department and The Board of management of a community school. ${ }^{336}$ In this case, Ms Z, who was employed as a school teacher, had a rare condition which meant that she had healthy ovaries but no uterus and so was unable to support a pregnancy. In order to become pregnant, Ms Z entered into a surrogacy arrangement via a Californian agency and a child was

ibid, [A2].

Case C-363/12 Z. v. A Government department and The Board of management of a community school [2014] 3 C.M.L.R. 20. 
born to the surrogate on 28 April 2010. Biologically, the child was the genetic child of Ms Z and her husband, having been created from their gametes; however, since $\mathrm{Z}$ had not been pregnant and could not give birth to a child, she was unable to satisfy the requirements under Ireland's Maternity Protection Act 1994 for taking paid maternity leave. She also did not qualify for paid adoptive leave, as provided by Ireland's Adoptive Leave Act 1995, since she was not adopting a child born through surrogacy. Ms Z argued before the CJEU that this refusal to allow her to access paid leave amounted to discrimination upon, among other grounds, disability. Her claim failed as the CJEU decided that she did not fall within the definition of disability for the purposes of the Framework Directive. The Court stated that:

the inability to have a child by conventional means does not in itself, in principle, prevent the commissioning mother from having access to, participating in or advancing in employment. In the present case, it is not apparent from the order for reference that Ms Z.'s condition by itself made it impossible for her to carry out her work or constituted a hindrance to the exercise of her professional activity. In those circumstances, it must be held that Ms Z.'s condition does not constitute a "disability". 337

It should also be stressed that the CJEU referred to the United Nations CRPD in the course of its judgment, indeed it went so far as to say, 'in the present case, the UN Convention is capable of being relied on for the purposes of interpreting Directive 2000/78, which must, as far as possible, be interpreted in a manner that is consistent with that Convention. ${ }^{338}$ The case of $Z$ thus illustrates the potential difficulties that an individual with HIV may have in persuading the CJEU that they are disabled for the purposes of the Framework Directive. Provided they are in good health and their medical condition is stable, they will face an uphill battle in persuading the CJEU that their condition imposes any hindrance whatsoever upon their participation in professional life.

A more measured construction of the concept of disability has also been echoed in the later CJEU decision of Fag og Arbejde v. Municipality of Billund. ${ }^{339} \mathrm{Mr}$ Kaltoft had worked for fifteen years as a child-minder for the Danish municipality of Billund. He was responsible for taking care of people's children in their own homes and was dismissed in November 2010 following an official dismissal hearing during which his obesity was mentioned. Before the national court, Kaltoft asserted that he was being discriminated against on the grounds of his obesity. Against this background, the national court referred several questions for a preliminary ruling, asking notably whether obesity can fall within the definition of disability for the purposes of the Framework Directive. Advocate General Jääskinen's opinion appeared supportive of such 
an idea and expressly referred to the concept of body mass index (BMI). ${ }^{340}$ In Advocate General Jääskinen's opinion, obesity might amount to a disability when it reaches the point where it clearly hinders an individual's full participation in professional life on an equal footing with others. In his opinion, 'most probably only WHO class III obesity, that is severe, extreme or morbid obesity, will create limitations, such as problems in mobility, endurance and mood, that amount to a "disability" for the purposes of Directive 2000/78. ${ }^{341}$ Jääskinen's construction was, however, rejected by the Court. In the Court's opinion obesity does not, in itself, constitute a 'disability' within the meaning of the Framework Directive. ${ }^{342}$ This is not to say that obese individuals can never acquire protection as individuals with disabilities under the Framework Directive as acknowledged by the Court:

Such would be the case, in particular, if the obesity of the worker hindered his full and effective participation in professional life on an equal basis with other workers on account of reduced mobility or the onset, in that person, of medical conditions preventing him from carrying out his work or causing discomfort when carrying out his professional activity. ${ }^{343}$

Once again, reference is made by the CJEU to the fact that a claimant's impairment must, in interaction with various barriers, hinder their full and effective participation in professional life. As Ferri and Lawson note the "focus on "professional life" seems to restrict the class of "persons with disabilities" covered by the [Framework] Directive to a narrower class of people than that which is envisaged in Article 1 of the CRPD'. ${ }^{344}$ This is unfortunate as in order to fully embrace the social model, future decisions of the CJEU need to recognise that the stigma faced by PLHA and many other individuals with impairments is disabling. Indeed, stigma is a factor imposed on top of PLHA's impairment that serves to unnecessarily isolate and exclude them from full participation in society. It is hoped that in future the CJEU will broaden the concept of disability for the purposes of the Framework Directive to encompass individuals who are prevented from participating fully and effectively in society and not only professional life, as the law currently stands. However, more recent decisions of the CJEU concerning disability have shown no movement or development from the CJEU regarding the definition of disability and instead, as

BMI is a formula that consists in dividing an individual's weight (in kilogrammes) by square of his/her height (in metres). The World Health Organisation (WHO, 2015) ranks obesity into three classes by reference to the BMI. Persons with a BMI of 30.00 to 34.99 are obese class I, persons with a BMI of 35.00 to 39.99 are obese class II, and persons with a BMI in excess of 40.00 are obese class III, which is sometimes referred to as severe, extreme or morbid obesity. Case C-354/13 Fag og Arbejde v. Municipality of Billund [2015] 2 C.M.L.R. 19., Opinion of AG Jääskinen, [56]. For detailed analysis of the Advocate General's opinion see K Ferris \& J Marson, 'Does Disability Begin at 40 ? Karsten Kaltoft v Kommunernes Landsforening, acting on behalf of the Municipality of Billund (Advocate General's Opinion)' (2014) 20 Web Journal of Current Legal Issues <http://webjcli.org/article/view/373/476> (accessed 29 March 2017). Case C-354/13 Fag og Arbejde v. Municipality of Billund [2015] 2 CMLR 19, [60].

Delia Ferri and Anna Lawson, 'Reasonable accommodation for disabled people in employment' (Directorate-General for Justice and Consumers 2016), 104. 
demonstrated by Petya Milkova v Izpalnitelen direktor na Agentsiata za privatizatsia $i$ sledprivatizatsionen control ${ }^{345}$ and Carlos Enrique Ruiz Conejero v Ferroser Servicios Auxiliares SA and Ministerio Fiscal, ${ }^{346}$ have continued to focus on the fact that:

[a]ccording to the Court's case-law, the concept of 'disability' within the meaning of Directive 2000/78 has to be understood as referring to a limitation of capacity which results in particular from long-term physical, mental or psychological impairments which, in interaction with various barriers, may hinder the full and effective participation of the person concerned in professional life on an equal basis with other workers $^{347}$

This is unfortunate, as the case of Bragdon ${ }^{348}$ illustrates that whilst a condition like HIV may not hinder an individual's functional participation in professional life, it certainly is able to limit an individual's full and effective functional participation in society. Indeed, the fact that it does hinder functional participation in society only serves to exacerbate stigma against PLHA who may be perceived as 'other' or 'different' from the able bodied majority due to their inability to fully participate in some aspects of society. This stigma knows no boundaries, and it exists within the place of work of PLHA and outside of it. The CJEU ought to recognise that for the purposes of the Framework Directive, individuals who are prevented from participating fully and effectively in any aspect of society due to stigma, and not just employment, are disabled and should fall within the remit of the Framework Directive. In addition, it may be perceived as somewhat troubling as to why Advocate General Kokott in the HK Danmark (Ring and Skouboe Werge $)^{349}$ case questioned whether a certain degree of severity of disability is required for the purposes of the Framework Directive. By referring to HIV and questioning whether a minimum level of severity is required, some might interpret Advocate General Kokott's comments as failing to take into account the fact that PLHA, in common with many other individuals with disabilities, face discrimination within employment not solely because of functional limitations due to the severity of their condition but often because of the substantial stigma associated with their condition. Indeed, as a consequence of recent medical advances in the treatment of HIV, PLHA within employment are now arguably more likely to be discriminated against because of the stigma associated with their condition as opposed to any functional limitations. By questioning whether a certain degree of severity is required and using HIV as an example, it would appear that Advocate General Kokott is moving the concept of disability away from the social model of disability. It is respectfully submitted that the focus appears to be solely upon a particular condition's degree of impact upon an individual's functional ability. If the CJEU is

Case C-406/15, EU:C:2017:198.

Case C-270/16, [2017] 3 CMLR 22.

ibid, [28].

Bragdon v Abbott 524 U.S. 624 (1998).

Joined Cases C-335/11 and C-337/11, [2013] 3 CMLR 21. 
to fully embrace the social model of disability, such considerations should not come into play. Indeed, the CJEU's approach to defining disability is not compatible with either the wording or spirit of the CRPD, and there is a real danger that the CJEU's mistaken approach will trickle down to national courts. ${ }^{350}$

Under the social model, disability is any societal factor that imposes restrictions upon people with an impairment. Thus, the correct focus of any future CJEU decision concerning the definition of disability for the purposes of the Framework Directive should be to examine what factors limit the individual in question from participating fully and effectively in society. To determine this, the approach should be upon the individual themselves and the effect that their impairment has upon them and not solely upon their impairment. As shall be seen in Chapter 6, some PLHA interviewed for the purposes of this research experienced no functional impairment and, as a result of various social factors, experienced no stigma or discrimination. Such individuals would not come within the definition of 'disabled' which is undoubtedly the correct approach for EU law to take. Other PLHA interviewed experienced no functional impairment but were subjected to stigma and discrimination on a sometimes frequent basis. Such individuals should acquire the protection of the Framework Directive especially when such societal stigma hinders their full and effective participation in the workplace. Focusing solely on the restricting factors of an individual's impairment and examining degrees of severity, as was suggested in the HK Danmark (Ring and Skouboe Werge) ${ }^{351}$ case, merely undermines any attempt at effectively implementing the social model of disability into EU law. At some point in the future, the question as to whether a minimum level of severity is required for the purposes of the Framework Directive will be addressed by the CJEU. The hope then must be that the CJEU recognise that some PLHA, in common with other individuals with disabilities, are precluded from full and effective participation in professional life by not merely environmental or physical barriers but also attitudinal and psychological ones. As such, a definition of disability which is firmly grounded in the social model needs to be adopted. Such a definition would recognise that an individual could be classified as disabled for the purposes of the Framework Directive, notwithstanding the fact that their condition does not functionally limit them in any way. The definition would also recognise the fact that individuals with disabilities are prevented from participating fully and effectively not just in professional life but in all aspects of society across the EU..$^{352}$

L Waddington, 'Saying all the right things and still getting it wrong: The Court of Justice's definition of disability and non-discrimination law' (2015) 22 (4) Maastricht Journal of European and Comparative Law 576.

Joined Cases C-335/11 and C-337/11, [2013] 3 CMLR 21.

Eurostat, Disability statistics - barriers to social integration' (25 October 2017).

< http://ec.europa.eu/eurostat/statistics-explained/index.php/Disability_statistics_-_barriers_to_social_integration> accessed 27 November 2017.
} 


\subsubsection{PROHIBITED CONDUCT UNDER THE FRAMEWORK DIRECTIVE}

Article 1 provides:

The purpose of this Directive is to lay down a general framework for combating discrimination on the grounds of religion or belief, disability, age or sexual orientation as regards employment and occupation, with a view to putting into effect in the Member States the principle of equal treatment.

Article 2 provides that discrimination shall include direct discrimination, indirect discrimination and harassment. Direct Discrimination is, 'taken to occur where one person is treated less favourably than another is, has been or would be treated in a comparable situation, on any of the grounds referred to in Article 1. ${ }^{353}$ Whereas indirect discrimination:

shall be taken to occur where an apparently neutral provision, criterion or practice would put persons having a particular religion or belief, a particular disability, a particular age, or a particular sexual orientation at a particular disadvantage compared with other persons unless:

(i) that provision, criterion or practice is objectively justified by a legitimate aim and the means of achieving that aim are appropriate and necessary. ${ }^{354}$

In relation to indirect disability discrimination, there is an additional defence available which is discussed further below. ${ }^{355}$

Harassment is defined as, 'when unwanted conduct related to any of the grounds referred to in Article 1 takes place with the purpose or effect of violating the dignity of a person and of creating an intimidating, hostile, degrading, humiliating or offensive environment., ${ }^{356}$

In addition, instructions to discriminate on the grounds of disability amounts to discrimination ${ }^{357}$ and Member States are required to prohibit victimisation in their domestic legal systems. ${ }^{358}$

In relation to all the protected grounds specified in the Framework Directive, it is possible to justify indirect discrimination if the respondent can show that their use of a provision, criterion

Article 2(2)(a).

Article 2(2)(b).

Article 2(2)(b)(ii).

Article 2(3)

Article 2(4)

Article 11. 
or practice has a legitimate aim and that the "means of achieving that aim are appropriate and necessary'. ${ }^{359}$ However, in relation to disability alone there is an additional defence ${ }^{360}$ to an indirect discrimination claim contained in Article 2(2)(b)(ii). This states that indirect discrimination shall be taken to occur unless:

as regards persons with a particular disability, the employer or any person or organisation to whom this Directive applies, is obliged, under national legislation, to take appropriate measures in line with the principles contained in Article 5 in order to eliminate disadvantages entailed by such provision, criterion or practice.

Article 5 contains the principle of reasonable accommodation ${ }^{361}$ for individuals with disabilities. It states that:

In order to guarantee compliance with the principle of equal treatment in relation to persons with disabilities, reasonable accommodation shall be provided. This means that employers shall take appropriate measures, where needed in a particular case, to enable a person with a disability to have access to, participate in, or advance in employment, or to undergo training, unless such measures would impose a disproportionate burden on the employer. This burden shall not be disproportionate when it is sufficiently remedied by measures existing within the framework of the disability policy of the Member State concerned.

The effect of this is that employers are permitted to either attempt to justify their use of a prima facie indirectly discriminatory provision, criterion or practice if the requirements of the defence contained in Article 2(2)(b)(i) are satisfied, or to rely upon the reasonable accommodation requirement contained in Article 5 in order to ensure the removal of obstacles and barriers to disabled individuals' equal participation in employment.

Whittle 362 argues that the manner in which the defence contained in Article 2(2)(b)(ii) is constructed creates a 'win-win' situation for both employers and individuals with disabilities. Employers are permitted to continue using provisions, criteria and practices that may not be essential to the job, and so objectively justifiable under the Article2(2)(b)(i), but which

\section{Article 2(2)(b)(i).}

In Ellis and Watson, EU Anti-Discrimination Law (2nd edn, Oxford University Press 2012) 408, the authors note that the UK Government initially appeared to take the mistaken view that the Framework Directive allowed Member States to choose under national legislation whether to apply justification or reasonable accommodation in cases concerning indirect disability discrimination. Wells also makes the same point in K Wells, 'The Impact of the Framework Employment Directive on UK Disability Discrimination Law’ (2003) 32 (4) Industrial Law Journal 254, 270.

The Equality Act 2010 uses the term reasonable adjustments. The principle is however the same.

R Whittle, The Framework Directive for equal treatment in employment and occupation: an analysis from a disability rights perspective' (2002) 27 (3) European Law Review 303. 
nevertheless they consider advantageous. By contrast, individuals with disabilities are afforded a 'greater chance of bring accommodated in relation to provisions and criteria that might be considered as "assets" from a recruitment perspective (as opposed to "essential job requirements"). 363

However, such an approach is disadvantageous for PLHA. First, there is a danger, due to the comments made in the Navas decision, that employers may feel they have no obligation to take reasonable measures in relation to an individual living with HIV who has disclosed their condition as it is questionable whether they are 'disabled' for the purposes of the Framework Directive. Second, PLHA are disadvantaged as a result of the hidden nature of their condition. Due to its invisibility to the naked eye, employers have no immediate manner of ascertaining an individual's HIV status unless an individual chooses to disclose this fact. Aside from the inherently personal nature of the decision to disclose, reference has already been made to the high levels of stigma and prejudice directed toward PLHA. Yet the duty to accommodate as contained in Article 5 means that employers need only take 'appropriate measures, where needed in a particular case'. When does this duty arise? Both the United Nations CRPD and the Framework Directive contain no information as to what knowledge of an individual's disability an employer must have before the duty to make a reasonable accommodation arises. However, Ferri and Lawson ${ }^{364}$ identify three main approaches amongst EU Member States:

First, the duty arises when the employer knows or ought to know about the disability of the employee. In this case, disabled employees (or prospective workers) would generally need to take steps to alert the employer to their disability and need for accommodations if their impairment were not apparent. Second, the duty is triggered by a specific request of the disabled person and thus arises only when the employer is informed about the disability and requested to provide an accommodation. Third, the duty arises when a competent public authority informs the employer.

Thus, in the UK the duty arises when the employer knows or ought reasonably to know about the individual's disability. Indeed, this point is addressed in the EA 2010, which states that an employer is

'not subject to a duty to make reasonable adjustments if [he/she] does not know, and could not reasonably be expected to know-

(a) in the case of an applicant or potential applicant, that an interested disabled person is or may be an applicant for the work in question;

ibid, 312

Delia Ferri and Anna Lawson, 'Reasonable accommodation for disabled people in employment' (Directorate-General for Justice and Consumers 2016). 
(b) ...that an interested disabled person has a disability and is likely to be placed at the disadvantage referred to... ${ }^{365}$

The knowledge requirement is also explicitly addressed in the Equality and Human Rights Commission's Code of Practice on Employment which states:

For disabled workers already in employment, an employer only has a duty to make an adjustment if they know, or could reasonably be expected to know, that a worker has a disability and is, or is likely to be, placed at a substantial disadvantage. The employer must, however, do all they can reasonably be expected to do to find out whether this is the case. What is reasonable will depend on the circumstances. This is an objective assessment. When making enquiries about disability, employers should consider issues of dignity and privacy and ensure that personal information is dealt with confidentially. ${ }^{366}$

In Cyprus, the Netherlands, Poland and Spain, the employer is only under a duty to make a reasonable accommodation where there is an express request by the employee. ${ }^{367}$ This is the case even if the individual's disability is readily apparent. Spain explicitly provides that an individual with a disability must inform the employer of their disability and request that an accommodation be made. ${ }^{368}$ Whilst in Poland, Article 23a of the Disabled Persons Act defines reasonable accommodation as 'necessary changes and adjustments in line with the specific needs reported to the employer, stemming from somebody's disability'. ${ }^{369}$ Consequently, it appears that, 'according to Polish law, disabled employees bear the duty to inform the employer about their special needs, and that, consequently, the duty arises when the employer receives a request.' 370

Finally, in Member States such as Bulgaria and Luxembourg, the duty to make a reasonable accommodation is only placed upon the employer when they are informed by an appropriate public body, such as the health service, about the health or medical condition of the individual Sch 8, para 20(1).

Equality and Human Rights Commission, 'Employment Statutory Code of Practice' (Equality and Human Rights Commission 2011), [6.19].

Delia Ferri and Anna Lawson, 'Reasonable accommodation for disabled people in employment' (Directorate-General for Justice and Consumers 2016).

Royal Legislative Decree 1/2013, of November 29, which approves the Consolidated Text of the General Law on the rights of persons with disabilities and their social inclusion, Article 68.2. Łukasz Bojarski, 'Country report Non-discrimination Poland' (Directorate-General for Justice and Consumers 2015). 
and the need for them to be provided with some form of reasonable accommodation. ${ }^{371}$

Although the matter has not been specifically addressed by the United Nations, Ferri and Lawson argue that only the first type of approach, i.e. that taken by the UK, is consistent with the CRPD. ${ }^{372}$ It also means that employers are not under a duty to accommodate unless they have actual or constructive knowledge of an individual's disability. PLHA are thus placed in a difficult situation. They may choose to keep their condition secret and fail to benefit from the reasonable accommodation duty afforded to other disabled individuals, or they disclose their condition to their employer in order to gain access to such opportunities but take the potential risk of being the subject of discrimination and stigma. Arguably, disclosing only certain aspects or requirements of their condition is not sufficient to impose a duty upon an employer to make a reasonable accommodation and an employer would be within their rights, as the law currently stands, to request more specific information about an individual's condition. Such information would be necessary to determine whether the employee's impairment amounts to a disability, i.e. whether, adopting the definition from HK Danmark (Ring and Skouboe Werge, it amounts to, 'a limitation which results in particular from physical, mental or psychological impairments which in interaction with various barriers may hinder the full and effective participation of the person concerned in professional life on an equal basis with other workers. ${ }^{, 373}$ Such information would be particularly relevant if the burden placed upon the employer by making the accommodation was significant but not outright unreasonable. To overcome this difficulty for PLHA and other individuals with hidden disabilities, it is submitted that EU law should implement a proactive reasonable accommodation duty in line with what the thesis proposes for UK law, discussed further at Chapter 4.2.8.

\section{$3.5 \quad$ CONCLUSION}

Despite the fact that the European Union has committed itself to combating discrimination against PLHA, HIV is not explicitly mentioned in either Article 19 of the TFEU or the Framework Directive. In addition, unlike the global and European Conventions discussed in sections 3.2 and 3.3, the characteristics of health status, other status or membership of a vulnerable group are not protected characteristics for the purposes of EU law. Instead, in order to be afforded protection from discrimination under EU law PLHA must demonstrate that their condition amounts to a disability for the purposes of the Framework Directive.

This may be problematic for PLHA due to the CJEU's definition of disability which, although it appears to be grounded in the social model of disability, focuses solely upon an individual's

ibid.

ibid, 67.

HK Danmark (Ring and Skouboe Werge) Joined Cases C-335/11 and C-337/11, [2013] 3 CMLR 21, [38]. 
ability to participate in professional life. Such an approach presents those PLHA in good health with an uphill battle in persuading the CJEU that their condition imposes a hindrance upon their ability to participate in professional life and thus qualify as disabled for the purposes of the Framework Directive. Some conditions, of which HIV is an example, impose limited functional limitations upon an individual but severe societal limitations. Certainly if the concept of disability developed by the CJEU is primarily concerned with the effect of an impairment's functional limitations upon an individual's ability to fully participate in professional life, then it is questionable whether PLHA will gain the protection of the Framework Directive.

The EA 2010 removes this level of doubt for PLHA by making it clear that HIV is a disability Indeed, when considered from a purely normative perspective, the designation of HIV as a disability by the EA 2010 is not only consistent with EU law but exceeds the minimum threshold with which national legislation is expected to comply due to Recital 28 of the Framework Directive. ${ }^{374}$ Thus, the EA 2010's designation of HIV as a disability provides PLHA in the UK with not only mandatory protection from discrimination but also the ability to request reasonable adjustments. This will be discussed in the next chapter in addition to the precise conduct against PLHA that the EA 2010 prohibits. 


\section{CHAPTER 4: THE DOMESTIC LEGAL FRAMEWORK RELATING TO HIV/AIDS}

\subsection{INTRODUCTION}

This chapter identifies and discusses the precise manner in which People living with HIV or with AIDS (PLHA) are afforded protection at the domestic level. It does this for two reasons. First, in order to determine whether the manner in which PLHA are protected by the UK law complies with relevant EU and international law. To do this emphasis will be placed upon comparing the Equality Act 2010 (EA 2010) with the UN Convention on the Rights of Persons with Disabilities (CRPD) and the Framework Directive as both have the ability to shape the EA 2010's definition of disability. In the case of the UN CRPD, it is due to that fact that it is one of the treaties specified by the UK as an EU treaty ${ }^{375}$ by the European Communities (Definition of Treaties) (UN CRPD) Order. ${ }^{376}$ In the case of the Framework Directive, it is due to the fact that EU law is supreme. Thus, in legal proceedings domestic courts must decide questions as to the meaning of any EU Treaty in accordance with the principles laid down by the Court of Justice of the EU. ${ }^{377}$ In addition, in areas where the EU has competence, EU law has status of a superior source of law within the EU's member states. ${ }^{378}$ The second reason why this chapter identifies and discusses the precise manner in which PLHA are afforded protection at the domestic level is to ascertain areas of relevance in order to assist in the formulation of questions for the empirical research part of this thesis.

In this respect, the chapter begins with a discussion in section 4.2 of the definition of disability employed by EA 2010 before section 4.3 examines the specific conduct prohibited by the EA 2010. In addition, the conduct prohibited by the EA 2010 will be compared against the UK's obligations under international and European law, and any deficiencies identified. Section 4.4 will then focus on the limited body of case law relating to HIV/AIDS at the domestic level.

The chapter will demonstrate that the EA 2010's primary definition of disability, as contained in section 6 , has been heavily influenced by the medical model of disability in contrast to the Act's designation of HIV as a disability which suggests use of the social model of disability. ${ }^{379}$ It will also demonstrate that in two areas the manner in which PLHA are protected by the EA

Within the definition of section 1(2) of the European Communities Act 1972.

The European Communities (Definition of Treaties) (UN CRPD) Order, SI 2009/1181.

Section 3(1) European Communities Act 1972.

Case C-6/64 Costa v ENEL [1964] ECR 585; Factortame v Secretary of State for Transport (No 2) [1991] 1 AC 603 (HL).

379 See section 3.2.5 for discussion and analysis of the models of disability.
} 
2010 fails to comply with relevant EU and international law. These two areas are: First, the EA 2010's failure to prohibit multiple discrimination and second, the manner in which the duty to make reasonable adjustments has been formulated by the EA 2010.

From the outset, it is important to acknowledge that the employment relationship is characterised by an imbalance of power in favour of the employer. According to Hepple, '[t]he starting point of any ideology of labour law, other than one of the market, is the inequality of the supplier and purchaser of labour power. Labour law is thus the law of subordinated or dependent labour. ${ }^{380}$ Despite this, both voluntary and legal regulation can restrict the unfettered exercise of power by the employer. For example, many organisations have written rules which detail particular aspects of the employment relationship, both in terms of rights and responsibilities for their employees. As well as these, the employer may adhere to informal practices that have developed over time within the organisation. In addition legal regulation, in the form of legislation, may establish minimum conditions of employment. ${ }^{381}$ It can also prohibit certain forms of less favourable treatment as seen in the subsequent discussion of the EA 2010.

\subsection{THE DEFINITION OF DISABILITY UNDER THE EQUALITY ACT}

Parliament took the step of classifying HIV as a disability and therefore afforded PLHA with protection under the Disability Discrimination Act 1995 (DDA 1995). Thus, as from 6 December 2005, PLHA were deemed to suffer from a disability, irrespective of whether they exhibit symptoms of their disease (DDA 1995, Schedule 1 paragraph 6A). This legislative amendment was enabled by section 18 of the Disability Discrimination Act 2005 which provided:

(1)Schedule 1 to the 1995 Act (which supplements the definition of "disability" in section 1 of that Act) shall have effect with the following amendments.

(3)Before paragraph 7 (persons deemed to be disabled) there is inserted-

“6A.(1)Subject to sub-paragraph (2), a person who has cancer, HIV infection or multiple sclerosis is to be deemed to have a disability, and hence to be a disabled person.

(2)Regulations may provide for sub-paragraph (1) not to apply in the case of a person who has cancer if he has cancer of a prescribed description.

B Hepple, 'The Future of Labour Law' (1995) 24 (4) Industrial Law Journal 303, 313.

See for example s86 of the Employment Rights Act 1996 which outlines the right and employees to receive minimum notice periods in the event of termination of the contract. 
(3)A description of cancer prescribed under sub-paragraph (2) may (in particular) be framed by reference to consequences for a person of his having it."

(5)At the end there is inserted-

\section{"Interpretation}

9.In this Schedule "HIV infection" means infection by a virus capable of causing the Acquired Immune Deficiency Syndrome.

This legislative amendment was acclaimed by those seeking to improve employment, public access, provision of services, transport and housing free from discrimination. It also drew attention to the stigma and discrimination that affects non-symptomatic HIV infection.

The DDA followed in the footsteps of legislation which prohibited discrimination on the grounds of gender and race, introduced in the mid-1970s, ${ }^{382}$ and during its passage through the House of Commons the Government was clearly of the opinion that this would be an historic piece of legislation. William Hague, Minister of State for the Disabled stated:

It is a landmark [Act]. It is the only comprehensive [Act] for disabled people ever introduced by a British Government. It will mark the United Kingdom out as one of the world leaders in Europe and move towards comprehensive anti-discrimination legislation for disabled people. ${ }^{383}$

In addition:

It sets this country on a clear, workable and unambiguous course to ending discrimination against disabled people. It will make a genuine difference to the opportunities and lives of our fellow citizens. ${ }^{384}$

Indeed, once enacted, the scope of the DDA 1995 was significant. It introduced a new regime of protection for disabled people in relation to employment and access to employment, the supply of goods and services, and the buying or renting of land or property. However, although arguably ground-breaking, it was also extremely technical, unwieldy and thus impenetrable to many. Indeed in Clark $v$ TDG trading as Novacold ${ }^{385}$ Mummery LJ noted that it was:

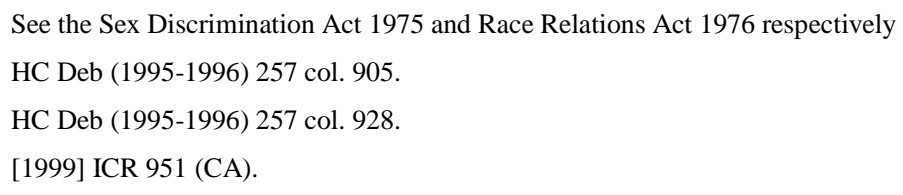


...an unusually complex piece of legislation which poses novel questions of interpretation. It is not surprising that different conclusions have been reached at different levels of decision. ${ }^{386}$

As previously noted, in an attempt to consolidate and harmonise the numerous pieces of antidiscrimination legislation, ${ }^{387}$ the Equality Act was passed in $2010 .{ }^{388}$ It received Royal Assent on 8 April 2010 — during the so called 'wash up' period after the General Election had been called but before Parliament was dissolved. The Act superseded the Disability Discrimination Act, yet PLHA receive similar protection. Thus, paragraph 6 to Schedule 1 of the Act states

(1) Cancer, HIV infection and multiple sclerosis are each a disability.

(2) HIV infection is infection by a virus capable of causing the Acquired Immune Deficiency Syndrome. ${ }^{389}$

The effect of this is that PLHA do no need to meet the standard definition of disability which is found at section 6 of the EA 2010. It states:

(1) A person (P) has a disability if-

(a) P has a physical or mental impairment, and

(b) the impairment has a substantial and long-term adverse effect on P's ability to carry out normal day-to-day activities.

ibid, 954.

Concerning disability, race, sex, age, religion, sexual orientation, gender reassignment, marriage, civil partnership, pregnancy, maternity, religion and belief.

The Equality Act 2010 makes it unlawful to discriminate against, harass or victimise a person: when providing a service (which includes the provision of goods or facilities) or when exercising a public function (Part 3 of the Act); when disposing of or managing premises (Part 4 of the Act; at work or in employment services (Part 5 of the Act); when providing places or access to facilities and services at an educational establishment (Part 6 of the Act); when making decisions as to the membership of associations, or access to associations' benefits, facilities and services (see ss 100103 of the Act). Detailed commentary of the Act can be found in M Connolly, Discrimination Law (Sweet \& Maxwell 2011); S Fredman, Discrimination Law (Oxford University Press 2011); A Lawson, 'Disability and Employment in the Equality Act 2010: Opportunities Seized, Lost and Generated' (2011) 40 (4) Industrial Law Journal 359; J Wadham, Blackstone's Guide to the Equality Act 2010 (Oxford University Press 2012).

Although the Secretary of State has retained a power to exclude certain types of cancer from this deeming provision via regulations, such power has not yet been used. 
The meaning is further expanded by Schedule 1of the EA 2010 ('Disability: supplementary provisions'), Regulations, ${ }^{390}$ Guidance $^{391}$ and a Code of Practice ${ }^{392}$ which detail matters to be taken into account in interpreting the definition.

Reference to the various models of disability has already been made in Chapter 3.2.5 and the definition of disability found at section 6 of the EA 2010 adopts the medical model of disability. This is best illustrated by the requirement that an impairment must affect the individual's ability to undertake normal day-to-day activities. The Guidance on matters to be taken into account in determining the question of disability states that 'it is not possible to provide an exhaustive list of day to day activities', ${ }^{393}$ but it provides a list of examples of when it would and would not be reasonable to regard an impairment as having a substantial adverse effect on the ability to carry out normal day-to-day activities. Factors which, if they are experienced by a person, it would be reasonable to regard as having a substantial adverse effect on normal day-to-day activities include:

'Difficulty going out of doors unaccompanied, for example because a person has a phobia.

Difficulty in going up and down steps, stairs or gradients, for example because movements are painful, uncomfortable or restricted in some way.

A total inability to walk, or difficulty walking other than at a slow pace or with unsteady or jerky movements.

Difficulty preparing a meal because of problems doing things like opening cans or other packages, peeling vegetables, lifting saucepans and opening the oven door.' ${ }^{394}$

The Guidance also makes it clear that activities do not fall within the category of normal dayto-day activities ' if they are normal only for a particular person, or a small group of people. ${ }^{395}$ Indeed in Goodwin v Patent Office ${ }^{396}$ it was made clear that: 'What is a day-to-day activity is

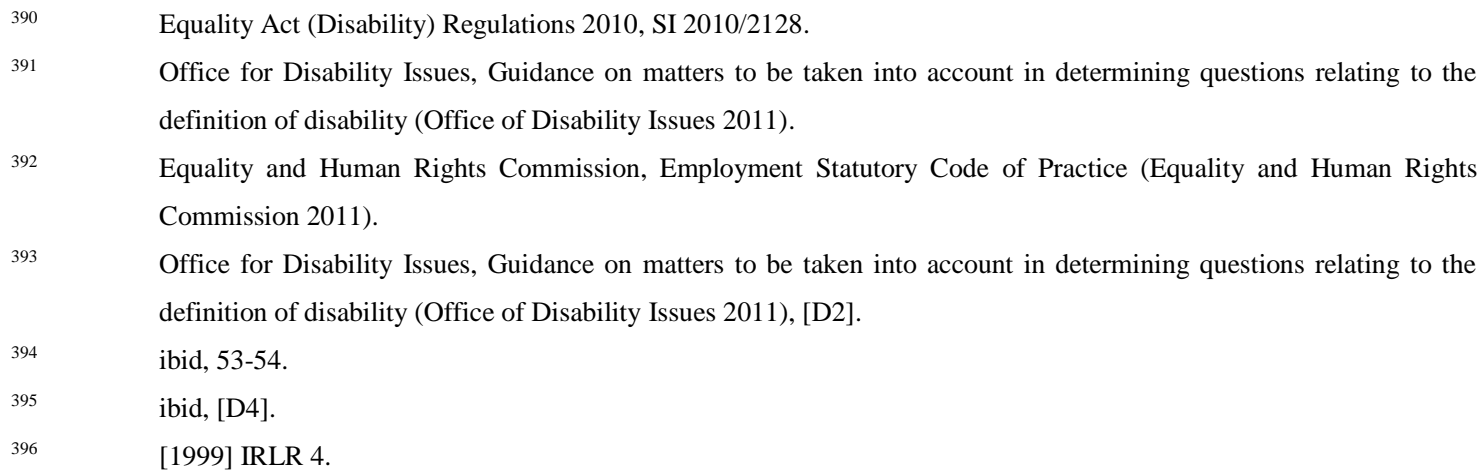


best left unspecified: easily recognised, but defined with difficulty. Thus, it is not directed to the person's own particular circumstances, either at work or home. The fact that a person cannot demonstrate a particular skill, such as playing the piano, is not an issue before the tribunal, even if it is considering a claim by a musician. ${ }^{397}$ This invites criticism of the constitution of disability employed by the EA 2010; the Act stifles the impact of social variables on disabled status, ignoring the environmental factors that may exacerbate disability and requiring a judgement based on generalities of most people's day-to-day activities and not the specific circumstances of the individual. ${ }^{398}$ The decision in Goodwin makes clear that a concert pianist who is unable to play the piano would not be held disabled, if they were able to undertake other normal day-to-day activities. Woodhams and Corby ${ }^{399}$ contend that in the individual's eyes, unable to pursue their life's ambition, they would be disabled. This emphasis on the concept of normality insidiously locates disabled individuals as socially inferior to non-disabled individuals. Disability is thus identified by reference to unfavourable deviance from the able bodied.

The EA 2010's emphasis on the impact of an impairment upon normal day-to-day activities also conflicts with the definition of disability developed by the CJEU for the purposes of Council Directive 2000/78/EC of 27 November 2000 establishing a general framework for equal treatment in employment and occupation [2000] OJ L 303/16 ('Framework Directive'). ${ }^{400}$ The same is true for the definition employed by the UN Convention on the Rights of Persons with Disabilities as both it and the Framework Directive draw heavily upon the social model of disability in their definitions of disability. ${ }^{401}$

Yet curiously in certain limited circumstances the 2010 Act appears to favour the adoption of the social model. Thus, 'an impairment which consists of a severe disfigurement is to be treated as having a substantial adverse effect on the ability of the person concerned to carry out normal day-to-day activities. ${ }^{402}$ Commenting on this provision the Court of Appeal in Northern Ireland, in Cosgrove v Northern Ireland Ambulance Service ${ }^{403}$ stated:

The reason that disfigurement is given access to the protected category by the device of the deeming provision is that those who are at risk of being refused employment or disadvantaged in relation to employment arrangements because of their appearance form a group that require equivalent protection to those who cannot carry out normal

ibid, [36].

C Woodhams and S Corby, 'Defining Disability in Theory and Practice: A Critique of the British Disability Discrimination Act 1995' (2003) 32 (2) Journal of Social Policy 159 ibid.

See section 3.4 for discussion of the Framework Directive's definition of disability.

See section 3.2.5 for discussion of the UNCRPD's definition of disability.

EA 2010, sch 1, para 3.

[2006] NICA 44. 
day-to-day activities. It appears to us that this special status reflects the increased consideration that it is felt should be accorded this group on account of their disfigurement. ${ }^{404}$

Once more with HIV there appears to be use of the social model. ${ }^{405}$ Thus, at the point of diagnosis for the majority of PLHA, it cannot be said that they accord with the traditional definition of disability as set out at section 6 of the EA 2010. Their impairment does not have a substantial and long-term adverse effect on their ability to carry out normal day-to-day activities. It is only if their health deteriorates to a significant extent that they will meet the definition. However, at this early stage of infection, it is the not the virus which is disabling but rather the interaction and reaction of members of society to the virus. Stigma rather than the virus disables the person living with HIV. ${ }^{406}$

Hepple categorises the Act as 'the core of the fifth generation of equality and anti-discrimination law in Britain'. 407 According to him it represents a continuation of the move towards comprehensive equality with a significant shift to a regime based on a unitary human rights perspective. It also commenced a period of transformative equality by the use of, for example, gender mainstreaming as a result of the Public Sector Equality Duty at section 149 of the EA 2010.

In terms of territorial scope, the EA 2010 covers Great Britain (England, Wales and, with a few exceptions, Scotland) but apart from a few provisions not Northern Ireland, which has transferred powers from Westminster on the areas of equal opportunities and discrimination. The intention is to leave it to employment tribunals to determine whether the law applies, 'depending for example on the connection between the employment relationship and Great Britain'. ${ }^{408}$ The EA 2010 is also within the scope of, and operates against the backdrop of, the Framework Directive which is the dominant legal framework concerning disability discrimination within the EU and with which the Act must comply. ${ }^{409}$ However, as well as having to be read in light of the Framework Directive, the EA 2010 must also be read in conjunction with any relevant provisions of the European Convention on Human Rights, including the non-discrimination provision contained in Article $14 .{ }^{410}$ In addition, although not legally binding upon our domestic courts, international treaties and agreements may also need

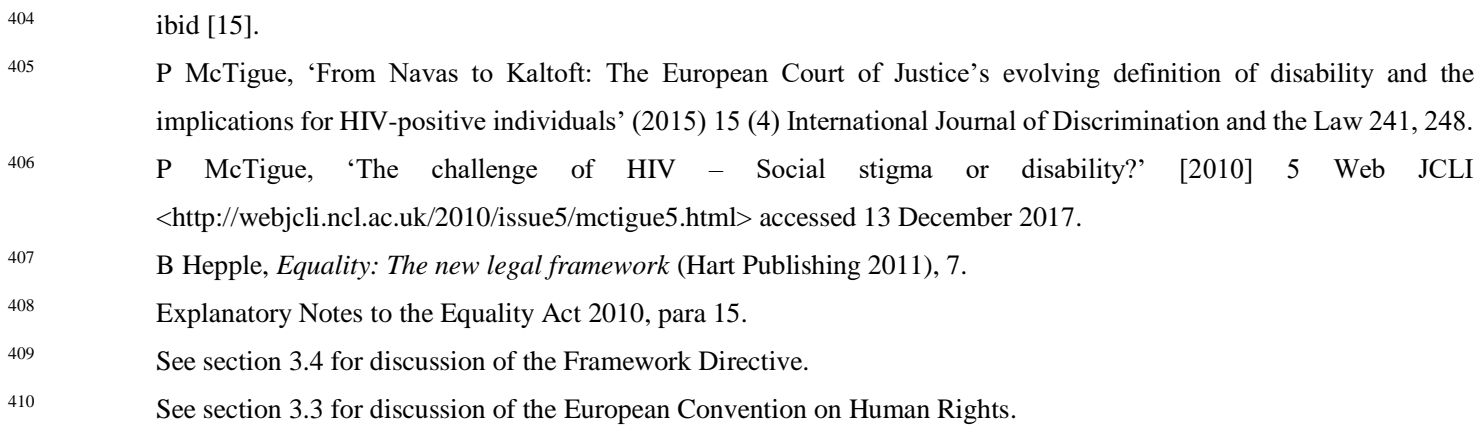


to be taken into consideration. The consequence of this is that disability discrimination law operates within an extremely complex, multi-layered framework which is impenetrable to the layperson and taxing for the lawyer.

Yet it is clear that in light of the unique level of discrimination and stigma ${ }^{411}$ associated with PLHA, the EA 2010 must provide a robust legal framework by means of which discrimination towards PLHA is prevented. Such a framework should also comply with relevant EU and international law and it is to the manner in which this framework operates and its compliance with the UN CRPD and EU law that this work now turns.

\subsection{PROHIBITED CONDUCT UNDER THE EQUALITY ACT}

\subsubsection{DIRECT DISCRIMINATION}

Direct discrimination is defined at section 13(1) of the EA 2010 as occurring when:

A person (A) discriminates against another (B) if, because of a protected characteristic, A treats B less favourably than A treats or would treat others.

In addition, in relation to disability, 'A does not discriminate against B only because A treats or would treat disabled persons more favourably than A treats B. ${ }^{412}$ For some of the other forms of discrimination, it is sometimes possible for employers to justify them. ${ }^{413}$ However, incidents of direct disability discrimination can never be justified. ${ }^{414}$ Essentially, there are two elements in direct discrimination; first, the less favourable treatment and second, the reason for that treatment. In Glasgow City Council v Zafar ${ }^{415}$, Lord Browne-Wilkinson put the matter this way when considering the near identical provisions relating to direct discrimination in the Race Relations Act 1976:

Although at the end of the day, s 1(1) of the Act of 1976 requires an answer to be given to a single question (viz has the complainant been treated less favourably than others on [the ground of that protected characteristic]?) ... it is convenient for the purposes of analysis to split that question into two parts - (a) less favourable treatment; and (b) [on grounds of that protected characteristic] ${ }^{416}$

See section 1.3 for details of the stigma PLHA face in the field of employment.

S 13 (3) Equality Act 2010

See for example indirect discrimination which is dealt with at s19 and discrimination arising from a disability which is dealt with at s 15 of the Equality Act 2010.

Except in relation to the protected characteristic of Age, see s13(2).

[1997] 1 W.L.R. 1659 (HL)

ibid 1663 . 
For example, in relation to disability the employer treats the employee less favourably simply because of their HIV status. To be treated less favourably necessarily implies some element of comparison: the complainant must have been treated differently to a comparator or comparators, be they actual or hypothetical. ${ }^{417}$ Where the protected characteristic is disability, comparison must be made with the treatment of a person who, though not disabled, has the same abilities as the claimant. ${ }^{418}$ In the field of disability, the question of what characteristics the comparator should possess has been a vexed question as demonstrated by the case of High Quality Lifestyles $v$ Watts. ${ }^{419}$ Analysis of this case and the comparator employed is required as it provides one example of judicial attitudes towards PLHA and, more importantly it assists in ascertaining areas of relevance in formulating questions for the empirical research part of this thesis.

High Quality Lifestyles is a decision of the Employment Appeal Tribunal (EAT). Mr Watts, who was aged 30 at the time of his initial Employment Tribunal hearing, was diagnosed as being HIV positive in June 2000. Watts applied for the post of support worker with the care company High Quality Lifestyles in January 2004. He completed a medical questionnaire which did not specifically ask about HIV but did ask, 'Do you take medicine regularly'. To this question he answered no, which was accurate at that time. To the final question, 'Do you suffer from any other ailments' he also answered no. Giving evidence, Watts informed the Tribunal that he did not consider his HIV status to be an ailment, "relying on the definition of "ailment" as a minor health issue. ${ }^{420} \mathrm{He}$ also sought the advice of the Terence Higgins Trust as to whether he should disclose his condition and was informed that there was no obligation upon him to do so.

High Quality Lifestyles provided specialist services to individuals with learning disabilities, autistic spectrum disorders and severely challenging behaviour. Support workers were required to live in a residential home with the service users and assist them with daily tasks. The behaviour of service users was unpredictable and occasionally support workers were scratched and bitten, sometimes drawing blood, as well as being punched and kicked. At the time of the hearing his condition was controlled by anti-retroviral combination therapy, however, when he applied for his job with High Quality Lifestyles he was not taking any medication for his HIV. This was a planned break from treatment undertaken in conjunction with his consultant's advice.

Watts began work in March 2004. He enjoyed the job, performed well and his managers thought highly of him. On 16 July 2004, he was promoted to the post of acting Shift Leader. At the time Watts felt secure enough to disclose his condition to his employer. He decided to take this step partly because an ex-partner was threatening to reveal his condition and partly because his HIV

Equality Act 2010, s 23(1).

Equality Act 2010, s 23(2).

[2006] I.R.L.R. 850.

[2006 IRLR] 850, 854 
consultant had prescribed a new combination of medicines which might have had side effects. He informed his manager and also consented to his employer contacting his consultant.

His consultant reported to his employer that the risk of onward transmission of HIV from occupational exposure was 'very small, but in the event of injury resulting from exposure when HIV virus is high, post exposure prophylaxis can be offered, although its success rate is not $100 \% .{ }^{421}$ Notwithstanding his consultant's assessment of the risk of onward transmission to a service user, Watts was summoned to a meeting. He was informed that a risk assessment would be carried out and told it was likely he would be dismissed as a result. He was also asked if he would agree to his HIV status being disclosed to the local social services department and all the employer's staff. He refused and on 16 August 2004 was suspended on the ground of dishonesty regarding the non-disclosure of his medical condition. The risk assessment concluded:

At this business occurrences of injuries resulting in broken skin and biting incidents are commonplace with documented cases where bites have required hospital treatment. The reason for a $4 / 5$ severity rating is that with a disease such as HIV the period between infection and full blown Aids is measured in years. Therefore, there remains the possibility of a cure or treatment being developed in the interim that may prevent death or significantly prolong active life. Similar possibilities exist for other infectious diseases. $^{422}$

On 5 October 2004, Watts was dismissed on grounds that his position was untenable in light of the risk assessment. An internal appeal against this decision was rejected.

Watts claimed direct discrimination under section $3 \mathrm{~A}(5)$. This stated:

A person directly discriminates against a disabled person if, on the ground of the disabled person's disability he treats the disabled person less favourably than he treats or would treat a person not having that particular disability whose relevant circumstances including his abilities, are the same as, or not materially different from, those of the disabled person.

He also claimed that he had been discriminated against for a reason related to his disability. ${ }^{423}$

The initial Employment Tribunal found that his employer had directly discriminated against $\mathrm{Mr}$ Watts contrary to section 3A(5) of the DDA 1995 on the ground of his disability by dismissing him. They also found that his employer had unlawfully discriminated against him for a

[2006] I.R.L.R. 850, 855.

ibid.

Section 3A(1) Disability Discrimination Act 1995 


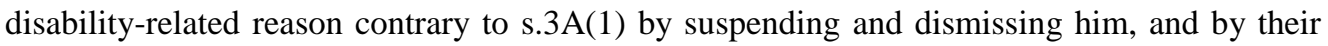
breach of confidentiality. High Quality Lifestyles appealed to the EAT.

The EAT held that the initial Employment Tribunal had erred in finding that Watts had been directly discriminated against because of his condition of being HIV positive, rather than because of the risk of transmission of that condition to others. Thus:

The error which the Tribunal made...was in failing to impute relevant circumstances to the hypothetical comparator. The circumstances were not as the Tribunal found, that the comparator should have a communicable disease. Assuming, as the Tribunal correctly did, that the comparator has the same abilities, skills and experience, the comparator must also have some attribute, whether caused by a medical condition or otherwise, which is not HIV positive. This attribute must carry the same risk of causing to others illness or injury of the same gravity, here serious and possibly fatal. If the Tribunal found that the comparator would have been dismissed, then the claimant has not been less favourably treated... ${ }^{424}$

With regard to the disability related discrimination claim, the EAT upheld the decision of the Employment Tribunal. It agreed that there was a sound basis for the Tribunal's conclusion and that the employers did not act reasonably because they failed to carry out a proper investigation or adequate risk assessment of the situation created by the claimant's condition.

As already stated, direct discrimination involves a comparison between the treatment of different individuals. To make that comparison, however, the cases of the claimant and the comparator must be such that there must be no material difference between the circumstances relating to each case. ${ }^{425}$ Yet there are a number of criticisms which can be levelled at the decision of the EAT in this case. First, as Keen notes, it is arguable that the EAT went too far in defining what would be an appropriate comparator in this case. ${ }^{426}$ By requiring that the comparator should also have an attribute that carried with it the same risk of causing illness or injury to others, the EAT constructed the relevant circumstances too narrowly. According to both Oulton and Keen, the effect of the EAT's analysis is that the comparator is someone who is HIV positive but by another name. ${ }^{427}$ Evidently a comparator such as that is almost always likely to be treated the same as the Claimant.

[2006 IRLR] 850, 858.

s3A(5) DDA 1995; s23 Equality Act 2010.

S Keen, 'Employment: Comparing comparators' (2011) 161 New Law Journal 308.

R Oulton, 'Employment / Discrimination: When is a clone not a clone?' (2009) 159 New Law Journal 1158; S Keen, 'Employment: Comparing comparators' (2011) 161 New Law Journal 308. 
The later Court of Appeal decision in Aylott v Stockton on Tees Borough Council ${ }^{428}$ to some extent mitigated the harshness of the decision in High Quality Lifestyles $v$ Watts with regard to the correct comparator in direct disability discrimination cases. In the Court of Appeal in this case, Lord Justice Mummery referred to the approach adopted in the earlier House of Lords' decision in Shamoon v Chief Constable of the RUC ${ }^{429}$ and stated:

I think that the decision whether the claimant was treated less favourably than a hypothetical employee of the council is intertwined with identifying the ground on which the claimant was dismissed. If it was on the ground of disability, then it is likely that he was treated less favourably than the hypothetical comparator not having the particular disability would have been treated in the same relevant circumstances. The finding of the reason for his dismissal supplies the answer to the question whether he received less favourable treatment: the real question is not so much about the hypothetical comparator, as whether the ET's finding on the ground of dismissal was supported by evidence. ${ }^{430}$

Although such an approach places less reliance on the use of a comparator, it does not do away with it all together. Lord Justice Mummery acknowledged that this was 'not saying that a hypothetical comparator can be dispensed with altogether in a case such as this: it is part of the process of identifying the ground of the treatment and it is good practice to cross check by constructing a hypothetical comparator. ${ }^{, 431}$

Indeed in Aitken $v$ Commissioner of Police of the Metropolis ${ }^{432}$ the Court of Appeal distinguished Aylott and appeared to adopt an approach akin to that originally employed by the Employment Appeal Tribunal in the High Quality Lifestyles $v$ Watts decision. In Aitken, the employee was a police constable and from the outset of his employment in 2002 he had intermittent absences for minor ailments. Obsessive compulsive disorder (OCD) and anxiety were diagnosed by a counsellor. During a pre-Christmas social event in 2005 he drank heavily, behaved inappropriately towards other police officers and was increasingly threatening as the event proceeded. Following protracted discussion and dispute as to the role he was capable of performing in the future on an ongoing basis for the Metropolitan Police, Aitken brought a complaint before the Employment Tribunal alleging disability discrimination. Part of his case was that he was less favourably treated as, 'he was wrongly perceived as being dangerous, either

[2010] EWCA Civ 910, [2010] IRLR 994.

[2003] UKHL 11; [2003] IRLR 285.

[2010] IRLR 994, [42].

ibid, [43].

[2011] EWCA Civ 582; [2012] I.C.R. 78. 
because those around him mistakenly thought that OCD made him dangerous, or that he had some mental illness that made him dangerous. ${ }^{2} 33$

Despite hearing little evidence on the issue of whether the claimant's treatment was due to his effect on the feelings of fellow employees, the Employment Tribunal found that his employer would have treated a person, whose relevant circumstances were similar, in an identical way. This was because his 'frightening behaviour was not stripped out of the characteristics of the hypothetical comparator, though his disability was. ${ }^{.434}$ As a consequence, 'The [Employment Tribunal] made clear that the relevant circumstances, including abilities, would be appearing to be aggressive and potentially subject to uncontrollable anger and strong emotion, which was particularly threatening to women. ${ }^{435}$

Following his unsuccessful claim in the Employment Tribunal and EAT, in the Court of Appeal he argued that:

[T] he comparator should not have the claimant's disability, so also the comparator should not have the characteristic of a necessary facet of the claimant's disability. That meant that the frightening effect of the claimant's behaviour should be removed from the characteristics of the comparator. It would then be found on a comparison that the claimant had been treated less favourably than the comparator would have been treated. ${ }^{436}$

The Court of Appeal disagreed stating that the case was distinguishable from Aylott. This was because in Aylott the claimant 'had never in fact been threatening to his colleagues, that his treatment by the respondent council was the result of stereotypical views of mental illness and that the council's treatment of him knowing of his disability provoked the behaviour which was then subject to a disciplinary investigation by the council. ${ }^{437}$ In this instance, the aggressive behaviour that concerned his colleagues was not excluded from the comparison as that "conduct was not alleged or proved in the [Employment Tribunal] either to be, or to be part and parcel of, his disability. ${ }^{438}$

Returning to the case of Aylott v Stockton on Tees Borough Council ${ }^{439}$, whilst the Court of Appeal agreed with the decision of the EAT in High Quality Lifestyles $v$ Watts $^{440}$ that a failure

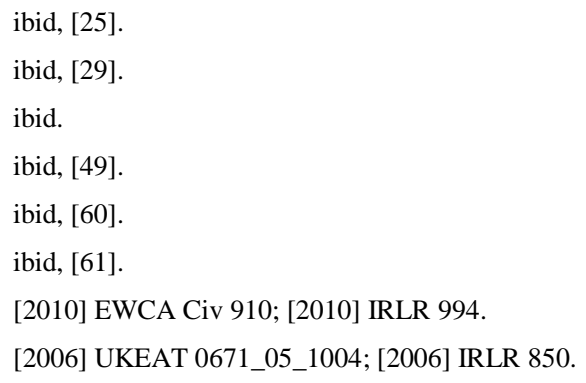


to attribute relevant circumstances to a relevant comparator may amount to an error of law, it held that Aylott's behavioural characteristics were not relevant circumstances because they arose out of his disability. ${ }^{441}$ A finding of direct discrimination was also supported by the fact that the Council had relied on a stereotypical view of persons with mental illnesses rather than up-to-date medical evidence regarding the effect of Aylott's illness upon his ability to continue in the employment of the Council. As supported by the case of $R$ (European Roma Rights) $v$ Prague Immigration Officer ${ }^{442}$ direct discrimination can occur, 'when assumptions are made that a claimant, as an individual, has characteristics associated with a group to which the claimant belongs, irrespective of whether the claimant or most members of the group have those characteristics. ${ }^{443}$ These principles stand in stark contrast to the stereotypical comparator in relation to PLHA as constructed by the EAT in High Quality Lifestyles. In the EAT in High Quality Lifestyles HHJ McMullen QC stated that, 'the comparator must also have some attribute, whether caused by a medical condition or otherwise, which is not HIV positive. This attribute must carry the same risk of causing to others illness or injury of the same gravity, here serious and possibly fatal' (emphasis added). ${ }^{444}$ Thus, this attribute is constructed of two concepts: risk and gravity. Yet it is clear that in conceiving the appropriate comparator the EAT's construction of the concepts of both risk and gravity were inherently flawed. It is to these two concepts, risk and gravity, that this work now turns.

In terms of risk, the EAT paid surprisingly little attention to any examination or analysis of the risk of transmission of HIV. This is surprising as the EAT referred to guidance issued by the Department of Health relating to the employment of health care professionals with HIV. ${ }^{445}$ Described as best practice guidance, it restricts HIV-infected healthcare workers from performing clinical procedures, known as 'exposure prone procedures', to protect patients from the risk of infection. Such procedures carry a risk that the healthcare worker could injure themselves and bleed into the patient's open tissues, with a consequent risk of infection. They occur mainly in specialties such as surgery, obstetrics and gynaecology, dentistry and some aspects of midwifery and specialist nursing. ${ }^{446}$

However, in relation to biting, the guidance clearly stated at para 5.4 of Annex A that:

Staff working in areas posing a significant risk of biting should not be treated as performing EPPs. In October 2003, UKAP considered a review of the available

ibid, [45].

[2004] UKHL 55; [2005] 2 AC 1.

[2010] IRLR 994, [46].

[2006] IRLR 850, 858.

Department of Health, 'HIV Infected Health Care Workers: Guidance on management and patient notification' (Department of Health 2005).

ibid. 
literature on the risk of onward transmission from health care workers infected with blood-borne viruses to patients. The review showed that the published literature on this subject is very scarce. In follow-up studies of incidents involving infected health care workers working with patients known to be 'regular and predictable' biters, there were no documented cases of transmission from the health care worker to the biter... ${ }^{447}$

The Guidance continued:

Based on the available information, it can only be tentatively concluded that even though there is a theoretical risk of transmission of a blood borne virus from an infected health care worker to a biting patient, the risk remains negligible. The lack of information may suggest that this has not been perceived to be a problem to date, rather than that there is an absence of risk.

UKAP has advised that, despite the theoretical risk, since there is no documented case of transmission from an infected health care worker to a biting patient, individuals infected with blood-borne viruses should not be prevented from working in or training for specialties where there is a risk of being bitten.

The evidence is dynamic and the area will be kept under review and updated in the light of any new evidence that subsequently emerges suggesting there is a risk. However, it is important for biting incidents to be reported and risk assessments conducted in accordance with NHS procedures. Biting poses a much greater risk to health care workers than to patients. Therefore employers should take measures to prevent injury to staff, and health care workers bitten by patients should seek advice and treatment, in the same way as after a needlestick injury. ${ }^{448}$

Thus, the literature available to the EAT at the time of their decision clearly indicated that there was minimal risk of onward transmission to a patient with a propensity to bite. Not only did the guidance indicate that there had been no documented cases of transmission from an infected health care worker to a patient, it also indicated that, in a healthcare environment, the greater risk came from HIV positive patients with a propensity to bite transmitting the virus onwards to a health care worker. The fact biting poses a much greater risk to health care workers than to patients was conveniently overlooked by the EAT.

More recent evidence further supports the position that the risk of onward transmission to a patient from a healthcare worker infected with HIV is negligible. A tripartite working group of Panel for Health Care Workers Infected with Blood-borne Viruses. 
the Expert Advisory Group on AIDS, the UK Advisory Panel for Healthcare Workers Infected with Blood-borne Viruses, and the Advisory Group on Hepatitis reviewed current national guidance on the management of healthcare workers infected with HIV, hepatitis B and hepatitis C. The group noted there have only been four reported incidents worldwide of HIV transmission from an HIV-infected healthcare worker to a patient and none in the UK, despite over 30 patient notification exercises between 1988 and 2008 in which nearly 10,000 patients were tested for HIV. ${ }^{449}$ Indeed, as previously noted, evidence indicates that there is a far greater risk of transmission of HIV from infected patient to healthcare worker than vice-versa as healthcare workers are more likely to come in contact with undiagnosed or diagnosed HIV-infected patients and be exposed to their blood through sharps injuries. Research undertaken by the Health Protection Agency illustrates that there have been 5 patient-to-healthcare workers HIV transmissions reported in the UK. ${ }^{450}$

The tripartite working group's assessment of available evidence and its expert opinion was that the risk of HIV transmission from an infected and untreated healthcare worker to a patient during exposure prone procedures is extremely low for the most invasive procedures and negligible for less invasive procedures. As a result of their assessment Public Health England, an executive agency of the Department of Health established in 2013, issued guidance which permitted HIV positive healthcare workers to perform exposure prone procedures provided they are on HAART, have a viral load less than 200 copies/ml, agree to medical supervision and monitoring every 3 months and register with an Occupational Health Monitoring Register managed by the UK Advisory Panel for Healthcare Workers Infected with Blood-borne Viruses UKAP. ${ }^{451}$ In light of this, the Employment Appeal Tribunal's decision employs a stereotypical vision that all PLHA are, by their very nature, infectious and represent a risk to public health. This clearly is not the case and should such a case have to be decided today, it would need to take into account the significant advances in the treatment of HIV.

HAART consists of the use of at least three antiretroviral drugs to suppress the virus, decrease an individual's viral load and slow the progression of the disease. The use of HAART can further reduce the risk of HIV transmission from an infected healthcare worker to a patient where the individual's plasma viral load is suppressed to a very low or undetectable level. Viral load is the term used to describe the amount of HIV present in an individual's body and viral load tests provide a numerical expression of the amount of HIV's genetic material in a given

\footnotetext{
449 Department of Health, 'Management of HIV-infected healthcare workers: A paper for consultation.' (Department of Health 2011).

$450 \quad$ Health Protection Agency, 'Occupational transmission of HIV - summary of published reports. March 2005 Edition' (HPA 2005)

451 Public Health England, 'The Management of HIV infected Healthcare Workers who perform exposure prone procedures: updated guidance' (Public Health England 2014).
} 
volume of blood. ${ }^{452}$ The more HIV present in an individual's blood, the higher their viral load, the faster their CD4 cell count will fall and consequently the greater the risk of them acquiring opportunistic infections. ${ }^{453}$ The aim of effective HIV treatment is to get an individual's viral load count to undetectable levels. This means that the amount of HIV in the system is at such low levels that ill-health due to HIV is unlikely and the risk of passing on HIV is, in effect, close to zero. ${ }^{454}$ It is called undetectable as the devices used to determine the viral load cannot detect HIV if there are fewer than 40 to 50 copies of HIV per cubic millilitre of blood. ${ }^{455}$ However, an undetectable viral load result does not necessarily mean that the blood sample is completely free of HIV. In fact, most people with undetectable viral loads will still have some HIV in their blood. ${ }^{456}$ In January 2008, a consensus statement from the Swiss Federal AIDS Commission attracted international attention by announcing that an individual with an undetectable viral $\operatorname{load}^{457}$ for at least six months, who remains adherent to their antiretroviral therapy, who is evaluated regularly by their HIV clinician and has no other sexually transmitted infections cannot transmit HIV through sexual contact. ${ }^{458}$ This finding has now been confirmed in later research by Rodger and others. ${ }^{459}$

There is no evidence relating to the risk of transmission of HIV-infected healthcare workers on HAART as the few documented transmissions relate to untreated healthcare workers, who are likely to pose a greater risk than individuals on HAART. ${ }^{460}$ What is important though is that expert opinion agrees that HAART will significantly reduce the risk of onward transmission by

World Health Organisation, 'Consolidated guidelines on the use of antiretroviral drugs for treating and preventing HIV infection' (World Health Organisation, 2nd edn, 2016).

Charles Bradley Hare, 'Clinical Overview of HIV Disease' (HIV Insite) <http://hivinsite.ucsf.edu/InSite?page=kb-0301-01\#S7.2X> accessed 13 November 2017.

P Vernazza and others, 'Les personnes séropositives nesouffrant d'aucune autre MST et suivant un traitement antirétroviral efficace ne transmettent pas le VIH par voie sexuelle’ (2008) Bull. Med. Suisse (89) 165; AJ Rodger and others, 'Sexual Activity Without Condoms and Risk of HIV Transmission in Serodifferent Couples When the HIVPositive Partner Is Using Suppressive Antiretroviral Therapy’ (2016) Journal of the American Medical Association 316 (2) 171; British HIV Association ' $U=U$ consensus statement: Risk of sexual transmission of HIV from a person living with HIV who has an undetectable viral load' (Prevention Access Campaign, 23 August 2018) <www.preventionaccess.org/consensus.> accessed 6 December 2018.

$\mathrm{R}$ Aschbacher and others 'Evaluation of three different commercial procedures for quantifying human immunodeficiency virus type-1 RNA levels' (1999) New Microbiology 22 (1) 1.

Information in this paragraph is from D Warrell, T Cox and J Firth (eds) Oxford Textbook of Medicine (5th edn Oxford University Press 2010).

Which they defined as less than 40 copies $/ \mathrm{ml}$.

P Vernazza and others, 'Les personnes séropositives nesouffrant d'aucune autre MST et suivant un traitement antirétroviral efficace ne transmettent pas le VIH par voie sexuelle' (2008) 89 Bull. Med. Suisse 165.

A Rodgers and others, 'Sexual Activity Without Condoms and Risk of HIV Transmission in Serodifferent Couples When the HIV-Positive Partner Is Using Suppressive Antiretroviral Therapy’ (2016) 316 (2) Journal of the American Medical Association 171.

Public Health England, 'The Management of HIV infected Healthcare Workers who perform exposure prone procedures: updated guidance' (Public Health England 2014). 
HIV-infected individuals. ${ }^{461}$ This proposition has relevance not only to healthcare workers but any individual employed in a position where their duties increase the risk of onward transmission of blood borne infections. From a wider perspective, the thinking could help significantly reduce the risk of HIV transmission within the wider population. This idea will be expanded upon in the discussion below concerning the second concept employed by the Employment Appeal Tribunal in their construction of an illness or injury of equivalence to HIV - gravity.

In terms of gravity, and the construction of the appropriate comparator for PLHA, in Watts HIV is equated to a 'life-threatening disease'. ${ }^{462} \mathrm{HIV}$ is thus incorrectly constructed as serious, possibly fatal and life-threatening. With advances in medical treatment and the advent of HAART, HIV is now manageable as a chronic disease in patients who have access to medication and who manage to suppress their viral load. ${ }^{463}$ Therefore, to construct and characterise HIV as a life threatening illness is incorrect. Undoubtedly HIV may have grave consequences if undiagnosed or untreated but simply to construct HIV as possibly fatal or life-threatening within the context and era of HAART merely contributes to the stigma already faced by PLHA. Constructing HIV in this manner also aids the mistaken, popular notion that HIV is a death sentence. This merely exacerbates fear amongst individuals who are members of groups at increased risk of contracting HIV or amongst individuals who engage in high risk activities. Such fear acts as a deterrent for a number of these people to undertake HIV testing. ${ }^{464}$ Indeed, if an individual had no knowledge of the efficacy of HAART, there is little incentive to discovering one had contracted a life-threatening and possibly fatal disease. This idea is borne out by the literature. ${ }^{465}$

Department of Health, 'Management of HIV-infected healthcare workers: A paper for consultation.' (Department of Health 2011); P Vernazza and others, 'Les personnes séropositives nesouffrant d'aucune autre MST et suivant un traitement antirétroviral efficace ne transmettent pas le VIH par voie sexuelle' (2008) 89 Bull. Med. Suisse 165;

A Rodgers and others, 'Sexual Activity Without Condoms and Risk of HIV Transmission in Serodifferent Couples When the HIV-Positive Partner Is Using Suppressive Antiretroviral Therapy’ (2016) 316 (2) Journal of the American Medical Association 171. 2006 IRLR 850, 857

J A Sterne and others, 'Long-term effectiveness of potent antiretroviral therapy in preventing AIDS and death: a prospective cohort study'(2005) The Lancet 378; Hasina Samji and others, 'Closing the Gap: Increases in Life Expectancy among Treated HIV-Positive Individuals in the United States and Canada' (2013) 8 (12) PLoS ONE < https://doi.org/10.1371/journal.pone.0081355> accessed 13 November 2017; The Antiretroviral Therapy Cohort Collaboration, 'Survival of HIV-positive patients starting antiretroviral therapy between 1996 and 2013: a collaborative analysis of cohort studies' (2017) 4 The Lancet 349.

A Bourne, 'Making it Count Briefing Sheet I: The Role of Fear in HIV Prevention' (Sigma Research 2010).

M Weait, 'Criminal Law and the Sexual Transmission of HIV' (2007) 68 (1) The Modern Law Review 121; C Dodds, A Bourne and M Weait, 'Responses to criminal prosecutions for HIV transmission among gay men with HIV in England and Wales' (2009) 17 Reproductive Health Matters 135; A Bourne, 'Making it Count Briefing Sheet I: The Role of Fear in HIV Prevention' (Sigma Research 2010). 
In 2017, there were an estimated 101,600 people living with HIV in the UK. ${ }^{466}$ However, approximately 7900 people within this cohort were unaware of their HIV status which has consequences for the health of both themselves and others. ${ }^{467}$ Individuals who are HIV positive but not aware of their status obviously do not present themselves for treatment and so do not receive HAART. The consequence of this failure to access HAART is the fact, discussed above, that if such individuals were employed in positions where their duties carried an increased risk of onward transmission of blood borne infections they would have a greater risk of transmitting the virus onwards. If the effectiveness of HAART were more widely publicised amongst the general public, HIV would not automatically be seen as life-threatening which should hopefully decrease stigma towards PLHA. Indeed such a decrease would help to overcome the myth that PLHA are 'not normal'. This could then lead to an acceptance amongst individuals who are members of groups at increased risk of contracting HIV that they themselves may actually be HIV positive, that PLHA are in fact normal, that PLHA can progress to old age provided they access medical treatment and that consequently they should be tested for HIV.

Returning specifically to the question as to whether the direct discrimination provisions of the EA 2010 comply with EU and international law, there are two aspects which must be considered in order to provide an answer. First, there is the issue of whether the normative provisions of the EA 2010 comply with EU and international law and second, whether those provisions are being interpreted by the judiciary in a manner consistent with EU and international law.

First, in relation to the normative provisions of the EA 2010, as discussed in section 3.2.5, the UN CRPD employs no specific definition of discrimination. However, both Waddington and Broderick $^{468}$ posit that the definition employed by the CRPD in Article 5(2) is capable of including direct discrimination, indirect discrimination, a denial of reasonable accommodation, harassment, instructions to discriminate, discrimination by association, multiple discrimination and discrimination based on perceived or past disability. As will be identified in the remainder of this chapter, with the exception of multiple discrimination, all of these forms of conduct are prohibited by the EA 2010. Moving to the Framework Directive, Article 2 prohibits direct discrimination which is, 'taken to occur where one person is treated less favourably than another is, has been or would be treated in a comparable situation, on any of the grounds referred to in Article 1. ${ }^{469}$ In addition, the CJEU case of Coleman $v$ Attridge Law ${ }^{470}$ makes it clear that associative discrimination is also prohibited by the Framework Directive. Thus, an employee

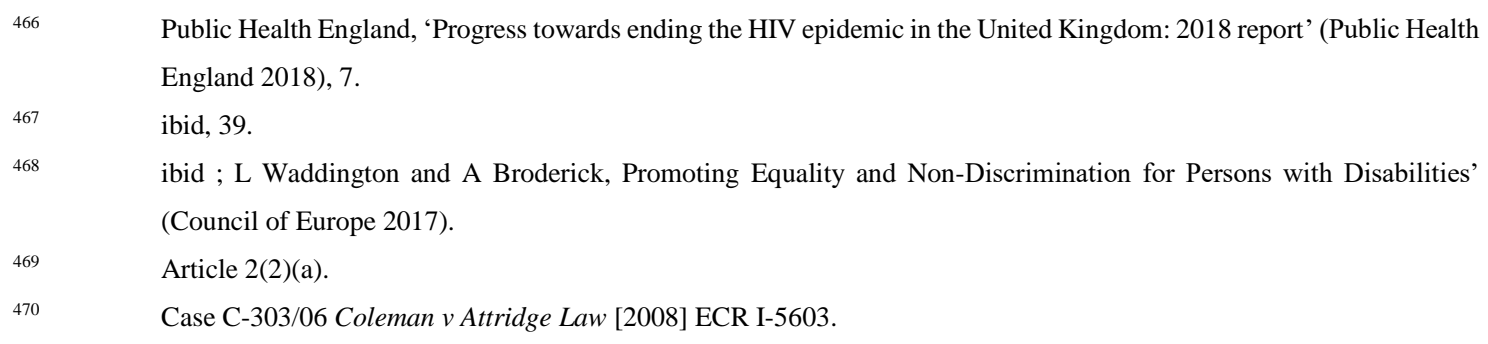

Public Health England, 'Progress towards ending the HIV epidemic in the United Kingdom: 2018 report' (Public Health England 2018), 7.

$467 \quad$ ibid, 39.

468 ibid ; L Waddington and A Broderick, Promoting Equality and Non-Discrimination for Persons with Disabilities' (Council of Europe 2017). 
who is associated with a PLHA and suffers discrimination as a result, has themselves been discriminated against on the grounds of disability within the meaning of section 13 of the EA 2010. The exact 'nature of the association' that will be afforded protection will require interpretation and guidance from the judiciary, however it appears assured that spouses, civil partners, immediate family members and those in long-term relationships with PLHA will be afforded the protection of section 13 of the EA 2010. ${ }^{471}$ Such an approach also accords with that taken by the European Court of Human Rights in Guberina v Croatia $^{472}$ where it was decided that Article 14 of the European Convention on Human Rights also protects individuals against discrimination due to their association with an individual with the protected characteristic of disability.

However, with regard to the question of whether the normative provisions of the EA 2010 are being interpreted by the judiciary in a manner which complies with EU and international law, the answer appears not. The case of High Quality illustrates the employ of an unfortunately outdated and stereotypical view of PLHA by the judiciary when constructing the appropriate comparator in relation to a direct discrimination claim for a person living with HIV. Although it should be stressed that judgment in the case of High Quality Lifestyles $v$ Watts ${ }^{479}$ was handed down before the UK Government ratified the CRPD in June $2009,{ }^{480}$ the later case of Aitken $v$ Commissioner of Police of the Metropolis ${ }^{481}$ illustrates the significant discretion that employment tribunals have in this area when constructing appropriate comparators. Thus, there still remains the possibility that at the domestic level, despite the CRPD's use of a social model of disability, attitudinal barriers remain when interpreting the relevant legislation, which hinder its ability to be interpreted in a manner consistent with the UK's obligations under the CRPD.

\subsubsection{MULTIPLE DISCRIMINATION}

Section 14 of the EA 2010 contains provision for a new concept of discrimination. It states: was to be construed. Did it have to be in the nature of a familial association (as in Coleman) or could it arise from membership of the same trade union (the issue in Thompson)? The Employment Appeal Tribunal held that there were no non-permitted categories. Instead the question should be one of causation i.e. had the association in question had the relevant effect on the treatment of the claimant?

$472 \quad$ App no 23682/13 (ECtHR, 22 March 2016)

479 [2006] I.R.L.R. 850.

$480 \quad$ For analysis of the CRPD in relation to UK law see S Fraser Butlin, 'The UN Convention on the Rights of Persons with Disabilities: Does the Equality Act 2010 Measure up to UK International Commitments?' (2011) 40 (4) Industrial Law Journal 428. 
(1)A person (A) discriminates against another (B) if, because of a combination of two relevant protected characteristics, A treats B less favourably than A treats or would treat a person who does not share either of those characteristics.

(2)The relevant protected characteristics are-

(a) age;

(b) disability;

(c) gender reassignment;

(d) race;

(e) religion or belief;

(f) sex;

(g) sexual orientation.

This concept is thus similar to direct discrimination but deals with the situation where a person is discriminated against because of a combination of two factors, for example being black and HIV positive or being gay and HIV positive. The legislation is intended to deal with situations where discrimination arises out of prejudice or assumptions specific to the combination of factors and is often referred to as multiple or intersectional discrimination. As Fredman notes, 'the more the person differs from a norm, the more likely she is to experience multiple discrimination, the less likely she is to gain protection. ${ }^{182}$ It is important to note that only two factors can be combined for the purposes of section 14. For example a black woman with HIV could bring a case on the basis of discrimination suffered as a black woman, as a woman with a disability or as black person with a disability.

This concept of multiple discrimination has the potential to be especially beneficial to Men who have sex with Men (MSM) and black Africans. MSM who are HIV positive might be marginalised and discriminated not only on the grounds of their sexual orientation but also on the grounds of disability, i.e. because they are HIV positive. Further, they may be subject to a combined level of discrimination because of the interaction of these two factors. For example, a gay man who is HIV positive might be denied employment at a nursery because of a perception, outdated and mistaken, that that they are promiscuous and a danger to children. Such prejudices would not be applied to lesbians or straight men who are HIV positive. Similarly, HIV positive black Africans might be denied employment in a kitchen because of an out-dated and mistaken perception that they lack intelligence and are unconcerned about personal health and safety. Such prejudices would not be applied to white Africans or Europeans who are HIV positive. 
Despite the benefits of section 14, Chancellor of the Exchequer, George Osborne, announced in the 2011 Budget that the section would not be brought into force. This was announced as part of the Government's Plan for Growth. The stated rationale being that:

To minimise regulatory burdens, the Government will scrap proposals for specific regulations which would have cost business over $£ 350$ million a year. This includes not extending the right to request time to train to businesses with less than 250 employees and not bringing forward the dual discrimination rule $\mathrm{e}^{483}$

This decision brought immediate condemnation from the NAT. Its Chief Executive, Deborah Jack, stated:

We condemn the Government's refusal to implement protection against dual discrimination - this is a backward step in the struggle for the rights of people with HIV and indeed many others who experience dual discrimination. We seem to be back in the bad old days where human rights were thought somehow to harm the economy. The Government should realise that ending all forms of discrimination in the workplace is not anti-business but provides us with the best possible workforce. We urge the Government to change its mind and take a stand for fairness. ${ }^{484}$

The failure to implement section 14 means that the EA 2010 is not fully compliant with the United Nations CRPD. As noted previously at Chapter 3.2.5, Article 6 of the United Nations CRPD introduces the concept of multiple discrimination This provides:

States Parties recognise that women and girls with disabilities are subject to multiple discrimination, and in this regard shall take measures to ensure the full and equal enjoyment by them of all human rights and fundamental freedoms. ${ }^{485}$

At first sight, Article 6 only pays recognition to the discriminative interplay between disability and females and, as observed at Chapter 1.2, in the UK HIV disproportionately affects MSM and black African heterosexuals. It is thus unfortunate that Article 6 makes no explicit reference to the multiple discrimination and interplay between, for example, disability and colour, race, nationality or sexuality. Hendriks is critical of the approach taken by Article 6 stating that the CRPD, 'fails to provide clear and convincing reasons why it has confined the meaning - and therewith the protective function - of 'multiple discrimination' to disability discrimination

HM Treasury, 'The Plan for Growth' (HM Treasury 2011), 23.

National AIDS Trust. 'March Budget takes rights away from people with HIV' (2011) <http://www.nat.org.uk/NewsandMedia/PressReleases/2011/March/Budget\%20takes\%20rights\%20away\%20from\%2 0people\%20with\%20HIV.aspx> accessed 13 June 2011. Article 6 (1) United Nations CRPD. 
affecting women and girls. ${ }^{486}$ Yet, Broderick argues, there is good authority to the effect that the Convention does protect individuals with disabilities from both multiple discrimination and intersectional discrimination. ${ }^{487}$ She asserts that, 'Article 5(2) of the CRPD must be read in conjunction with the list contained in paragraph (p) of the Preamble of the Convention.' ${ }^{488}$ This preamble expresses States Parties' concern about, 'the difficult conditions faced by persons with disabilities who are subject to multiple or aggravated forms of discrimination on the basis of race, colour, sex, language, religion, political or other opinion, national, ethnic, indigenous or social origin, property, birth, age or other status. ${ }^{489}$ Although it is questionable whether Article 5 (2) will be interpreted in such a manner, the utilisation of such an approach would enable a much broader conception of multiple discrimination to be developed.

The failure to implement section 14 of the EA 2010 does not however place the UK in breach of EU law. In the field of employment, the non-binding Recital (3) of the Framework Directive merely states that, 'In implementing the principle of equal treatment, the Community should, in accordance with Article 3(2) of the EC Treaty, aim to eliminate inequalities, and to promote equality between men and women, especially since women are often the victims of multiple discrimination.' In addition, although the question as to whether multiple discrimination is prohibited by EU law has generated substantial academic commentary, ${ }^{490}$ the CJEU's decision in Parris v Trinity College Dublin ${ }^{491}$ makes clear that, "while discrimination may indeed be based on several of the grounds set out in Article 1 of [the Framework Directive], there is, however, no new category of discrimination resulting from the combination of more than one of those grounds, such as sexual orientation and age, that may be found to exist where discrimination on the basis of those grounds taken in isolation has not been established.' 492

Aart Hendriks, 'The UN Disability Convention and (Multiple) Discrimination: Should EU Non-Discrimination Law Be Modelled Accordingly’ (2010) 2 European Year Book of Disability Law 7, 22.

A Broderick, The long and winding road to equality and inclusion for persons with disabilities: The United Nations Convention on the Rights of Persons with Disabilities (Intersentia 2015), 104. ibid.

Preamble to CRPD, para 16.

See for example S Fredman, 'Double trouble: multiple discrimination and EU law', (2005) 2 European AntiDiscrimination Law Review 13; D Schiek and V Chege, V, (eds), EU Non-Discrimination Law, Comparative Perspectives on Multidimensional Equality Law (Routledge-Cavendish 2009); I Solanke. 'Putting Race and Gender Together: a New Slide Approach to Intersectionality’ (2009) 72 (5) Modern Law Review 723; D Schiek and A Lawson (eds), EU Non-Discrimination Law and Intersectionality (Ashgate 2011); K Monaghan, 'Multiple and Intersectional discrimination in EU law' (2011) 13 European Anti-discrimination Law Review 20; R Xenidis, 'Multiple Discrimination in EU Law: Towards Redressing Complex Inequality?' in U Belavusau and K Henrard (eds), EU AntiDiscrimination Law beyond Gender (Hart 2018). 
However, at this point it is worth reiterating the response of one black, female participant to research $^{493}$ undertaken by Fesko ${ }^{494}$ into disclosure decisions as identified in section 1.4. This participant stated:

With my boss, he was a joker - jokes around and stuff like that - but they had a lot of semi-gay bashing and they raised some very nasty little jokes that I didn't care for, and people were joking around and by me being black and it was an all-white company I was working for, I decided not to tell.

Although the above quote concerns the individual's anxieties about disclosing her HIV status to her employer, it is apparent that she was concerned about the possible discrimination she might face due to her identity as a black HIV positive female being managed by a male manager in a homophobic environment. Thus, as the discrimination that PLHA face is often inextricably bound up with multiple other factors, the issue of multiple discrimination against PLHA is one that will be explicitly addressed by the empirical research in Chapters 6 and 7.

\subsubsection{INDIRECT DISCRIMINATION}

At its simplest, indirect discrimination occurs where a seemingly neutral rule or practice operates to the disadvantage of a protected group and will be unlawful unless it can be justified. In the UK, the concept of indirect discrimination dates back to the drafting of the Sex Discrimination Act in 1975. Newman ${ }^{495}$ notes that the EA 2010 was written to take account of a concept derived from the case law of the United States Supreme Court in Griggs v Duke Power Company. ${ }^{496}$ In that case, the court held that a requirement to have a high school diploma or to pass a standardised 'intelligence' test for certain posts had a disproportionate impact on black candidates. The requirement was not related to the needs of the company and had only been introduced when the company's previous policy of workplace segregation was made illegal by the Civil Rights Act 1964. Consequently, the Supreme Court held that the requirement was discriminatory even though, in theory, it applied to all job applicants regardless of race.

Thus, as is apparent from the case above, indirect discrimination seeks to move beyond formal equality towards a more substantive equality of results. This was a point recognised by Lady Hale in the case of $R$ (On the application of E) $v$ Governing Body of JFS and others. ${ }^{497}$ This was 
a case concerning the interplay between discrimination based upon racial and religious grounds, in which she noted that:

The basic difference between direct and indirect discrimination is plain... The rule against direct discrimination aims to achieve formal equality of treatment: there must be no less favourable treatment between otherwise similarly situated people on grounds of colour, race, nationality, or ethnic or national origins. Indirect discrimination looks beyond formal equality towards a more substantive equality of results: criteria which appear neutral on their face may have a disproportionately adverse impact upon people of a particular colour, race, nationality or ethnic or national origins.

Direct and indirect discrimination are mutually exclusive. You cannot have both at once. As Mummery LJ explained in Elias at para 117 "the conditions of liability, the available defences to liability and the available defences to remedies differ". The main difference between them is that direct discrimination cannot be justified. Indirect discrimination can be justified if it is a proportionate means of achieving a legitimate aim. $^{498}$

The decision to protect disabled individuals from indirect discrimination is a relatively new one. There was no specific provision concerning indirect discrimination on the ground of disability within the DDA 1995, the concept only being introduced by the EA 2010. According to the Explanatory Notes to the EA 2010, it was included, 'after consultation following the judgment of the House of Lords in the case of London Borough of Lewisham v Malcolm ${ }^{499}$ which concerned the interpretation of the provision on disability related discrimination in the Disability Discrimination Act 1995, 500

The concept is given effect by section 19 of the EA 2010 which provides:

(1) A person (A) discriminates against another (B) if A applies to B a provision, criterion or practice which is discriminatory in relation to a relevant protected characteristic of B's.

(2) For the purposes of subsection (1), a provision, criterion or practice is discriminatory in relation to a relevant protected characteristic of B's if-

(a) A applies, or would apply, it to persons with whom B does not share the characteristic,

ibid [56]-[57].

[2008] UKHL 43, [2008] 1 A.C. 1399

Explanatory Notes to the Equality Act 2010, para 81. 
(b) it puts, or would put, persons with whom B shares the characteristic at a particular disadvantage when compared with persons with whom B does not share it,

(c) it puts, or would put, B at that disadvantage, and

(d) A cannot show it to be a proportionate means of achieving a legitimate aim.

There is no definition of 'provision, criterion or practice' found in the legislation and consequently, it is left to the discretion of individual Tribunals and Courts. Thus, in British Airways plc $v$ Starmer ${ }^{501}$ the EAT held that the words 'provision, criterion or practice' must not be given a narrow meaning. Indeed, in United First Partners Research v Carreras $^{502}$ the Court of Appeal held that an expectation or assumption that an employee would work late into the evening could constitute a provision, criterion or practice, even if the employee was not coerced to do so. Therefore, by analogy, if a company has a strict shift pattern which makes it difficult for employees to adjust their shifts, this would put PLHA who wish to attend prescheduled medical appointments at a disadvantage when compared to other employees. Alternatively, if an employer organises a team building event in a country where there are entry restrictions for individuals with blood borne viruses, this would put employees with HIV at a disadvantage due to the difficulties faced in attending. There is, however, always the defence of justification open to the employer, a topic to which we shall now turn.

This defence is to be found in section 19(2)(d) of the EA 2010 and asks whether the Provision, Criterion or Practice can be found to be a 'proportionate means of achieving a legitimate aim'.

Neither domestic nor European legislation defines the term 'legitimate aim' instead it is a question of fact for the relevant court or tribunal. However, Mummery LJ stated that, "the objective of the measure in question must correspond to a real need and the means used must be appropriate with a view to achieving the objective and be necessary to that end. ${ }^{503}$ For example, the health, welfare and safety of individuals may qualify as legitimate aims. Thus, if all senior healthcare professionals of a private hospital were required to attend a five day compulsory training course covering the minimisation of infection risks to patients, this would qualify as a legitimate aim. If the training course were held overseas in a country with entry restrictions in respect of individuals with any blood borne virus, the fact that a HIV-positive healthcare professional would be prevented from attending the training would amount to them being placed at a disadvantage. However, the question would then arise as to whether the means of achieving the legitimate aim, here the health, welfare and safety of residents, was proportionate. The principle of proportionality requires an objective balance to be struck

[2005] UKEAT 0306_05_0607, [2005] IRLR 863.

[2018] EWCA Civ 32.

$R$ (Elias) $v$ Secretary of State for Defence [2006] EWCA Civ 1293, [2006] IRLR 934, [151]. 
between the discriminatory effect of the measure and the needs of the undertaking. ${ }^{504}$ To do this, an Employment Tribunal would evaluate the particular discriminatory effect of the requirement to attend the course against the employer's reasons for applying it, taking into account all the relevant facts. In this example, if training of a similar standard could be provided in a country with no entry restrictions relating to individuals with blood borne viruses, the employer's practice of holding the training course in a country with entry restrictions would not be capable of justification and so indirect discrimination would be established.

Under the Framework Directive indirect discrimination is prohibited by Article 2(2)(b)..$^{505}$ Recently however, the CJEU has extended the scope of indirect discrimination in race discrimination cases to cover associative indirect discrimination in the case of CHEZ Razpredelenie Bulgaria AD v Kosimia za Zashtita ot Diskriminatsia. ${ }^{506}$ This case concerned the placing of electricity meters in a predominantly Roma district in Bulgaria. ${ }^{507}$ CHEZ RB, the electrical supplier, decided to fix the electricity meters at a height of approximately 6 metres in the Gizdova mahala district of the town of Dupnitsa, as opposed to the usual 1.7 metres in other areas. The reason for placing the meters at this height was that there had been several instances of meter tampering and unlawful connections to the electricity network within the area. Ms Nikolova, who ran a business within the affected area, complained to the Bulgarian Commission for Protection against Discriminations. She argued that she had been placed at a disadvantage by the height of the meters as she was unable to see her meter to get readings and as a result all of her bills were overestimated. In addition, she argued that Roma people were disadvantaged by CHEZ RB's practice when compared to others and that, though not of Roma origin herself, she suffered the same disadvantage. Taken together, she said this amounted to indirect discrimination for the purposes of Article 2(2)(b) of the Racial Equality Directive. ${ }^{508}$

Advocate General Kokott relied on the earlier decision of the CJEU in Coleman v Attridge $L a w^{509}$ where direct associative discrimination on the grounds of disability was held to be capable of being prohibited by the Framework Directive. Kokott stated that:

The principles from Coleman can be readily applied to the present case even though on that occasion [the Racial Equality Directive] was not at issue, but the related [Framework Directive]. These two sister directives are substantively similar on the

See for example Case-170/84 Bilka-Kaufhaus GmbH v Weber von Hartz [1986] ECR 1607; MacCulloch v ICI [2008] UKEAT 0119_08_2207, [2008] IRLR 846.

Discussed earlier in section 3.4.2.

Case C-83/14 CHEZ Razpredelenie Bulgaria AD v Kosimia za Zashtita ot Diskriminatsia [2016] 1 CMLR 491

For detailed discussion of the case see Rossen Grozev, 'A Landmark Judgment of the Court of Justice of the EU - New Conceptual Contributions to the Legal Combat against Ethnic Discrimination' (2015) 15 The Equal Rights Review 168. Council Directive 2000/43/EC of 29 June 2000 implementing the principle of equal treatment between persons irrespective of racial or ethnic origin [2000] OJ L 180/22.

Case C-303/06 Coleman v Attridge Law [2008] ECR I-5603.
} 
relevant points at issue here and are ultimately an expression of the principle of equality, which is one of the general principles of EU law, as recognised in Article 21 of the Charter of Fundamental Rights..$^{510}$

The Grand Chamber agreed with such analysis stating that:

the scope of the [Racial Equality Directive Directive] cannot, in the light of its objective and the nature of the rights which it seeks to safeguard, be defined restrictively, is, in this instance, such as to justify the interpretation that the principle of equal treatment to which that directive refers applies not to a particular category of person but by reference to the grounds mentioned in Article 1 thereof, so that that principle is intended to benefit also persons who, although not themselves a member of the race or ethnic group concerned, nevertheless suffer less favourable treatment or a particular disadvantage on one of those grounds (see, by analogy, judgment in Coleman, C-303/06, EU:C:2008:415, paragraphs 38 and 50).[sic] ${ }^{511}$

It must be remembered that $C H E Z$ was specifically concerned with the Racial Equality Directive and, as such, it may be too early to accurately assess the extent to which CHEZ heralds a shift towards the CJEU harnessing the concept of associative indirect discrimination in cases specifically involving the Framework Directive. However, if the CJEU in a future decision decided that associative indirect discrimination is also prohibited by the Framework Directive, the effect would be that section 19 of the EA 2010 would, prima facie, appear incompatible with EU law. Section 19 of the EA 2010 requires that a claimant must possess the relevant protected characteristic if they wish to present a claim of indirect discrimination. No such distinction was made in CHEZ for the purposes of EU law and consequently, parliamentary amendment of section 19 would be necessary in order to allow indirect discrimination claims to be brought by those associated with individuals possessing the relevant protected characteristic.

\subsubsection{DISCRIMINATION ARISING FROM A DISABILITY}

Section 15(1) of the EA 2010 provides:

A person (A) discriminates against a disabled person (B) if-

(a) A treats B unfavourably because of something arising in consequence of B's disability, and 
(b) A cannot show that the treatment is a proportionate means of achieving a legitimate aim.

In addition, section 15(2) makes it clear that the prohibition from discrimination arising from disability does not apply 'if A shows that A did not know, and could not reasonably have been expected to know, that B had the disability'. The concept of discrimination arising from a disability is said in the explanatory notes of the EA 2010 to be 'aimed at re-establishing an appropriate balance between enabling a disabled person to make out a case of experiencing a detriment which arises because of his or her disability, and providing an opportunity for an employer or other person to defend the treatment. ${ }^{, 512}$

The concept of less favourable treatment because of something arising in consequence of B's disability is broad enough to cover a reason which relates not only to the disability itself, but also to aids or devices (such as wheelchairs) used to mitigate or eliminate the disability. The Employment Code of Practice issued by the Equality and Human Rights Commission states, 'The consequences of a disability include anything which is the result, effect or outcome of a disabled person's disability. The consequences will be varied, and will depend on the individual effect upon a disabled person of their disability. ${ }^{, 513}$ One example would be the use of absence by an employer as a selection criterion when undertaking a redundancy selection. This criterion is likely to impact disproportionately upon PLHA who may have had to take additional absence due to HIV-related illnesses. ${ }^{514}$ As their poor attendance record was caused by a disability, dismissing a PLHA following such a selection exercise could amount to discrimination.

The DDA 1995 had previously provided protection from 'disability related discrimination'.515 However, following the House of Lords' decision in London Borough of Lewisham $v$ Malcolm ${ }^{516}$ these provisions were considered inadequate due to their Lordship's reasoning as to the question of the correct comparator in cases of this nature.

\footnotetext{
512 Explanatory Notes to the Equality Act 2010, para 70.

513 Equality and Human Rights Commission, 'Employment Statutory Code of Practice' (Equality and Human Rights 2011), para 5.9.

It should however be borne in mind that, in general, PLHA are no more likely to be absent from work due to ill health than any other employed person. See J Leigh and others, 'Absenteeism and HIV infection' (1997) 4 (5) Applied Economics Letters 275; James Habyarimana, Bekezela Mbakile and Cristian Pop-Eleches, 'The Impact of HIV/AIDS and ARV Treatment on Worker Absenteeism: Implications for African Firms' (2010) 45 Journal of Human Resources 4. 
To determine whether the 'unfavourable treatment arise[s] in consequence of B's disability', the Employment Appeal Tribunal in Basildon \& Thurrock NHS Foundation Trust $v$ Weerasinghe ${ }^{517}$ has explained that:

The current statute requires two steps. There are two links in the chain, both of which are causal, though the causative relationship is differently expressed in respect of each of them. The Tribunal has first to focus upon the words "because of something", and therefore has to identify "something" - and second upon the fact that that "something" must be "something arising in consequence of B's disability", which constitutes a second causative (consequential) link. 518

In addition, in City of York Council v Grosset the Court of Appeal decided there is no requirement that the defendant should be aware that the 'something' referred to in the section 15(1)(a) has occurred in consequence of a claimant's disability. ${ }^{519}$

In terms of justification, section 15(1)(b) of the EA 2010 provides that discrimination arising from disability will be established where the less favourable treatment because of something arising in consequence of B's disability has been shown, and 'A cannot show that the treatment is a proportionate means of achieving a legitimate aim'. This amounts to a change from the test employed by the DDA 1995 and brings disability discrimination in line with the test employed for indirect discrimination for the other relevant prohibited grounds.

Under section s 3A(6) DDA 1995, justification was not possible if the employer was under a duty to make reasonable adjustments and had failed to comply with that duty. Whilst there is no specific re-enactment of s 3A(6) DDA 1995 in the EA 2010, in Carranza $v$ General Dynamics Information Technology Ltd ${ }^{520}$ the Employment Appeal Tribunal noted that the duty to make reasonable adjustments and the concept of discrimination arising from disability have the potential to interact with one another. Thus, '[a]n employer who is in breach of a duty to make reasonable adjustments and dismisses the employee in consequence is likely to have committed both forms of prohibited conduct. ${ }^{521}$

Section 15 is compliant with the Framework Directive and, indeed, provides an additional form of action to a claimant that is not provided for explicitly by the Framework Directive. Furthermore, in relation to the section's relationship with the European Convention on Human

[2016] ICR 305

ibid, [26].

[2018] EWCA Civ 1105.

[2014] UKEAT 0107_14_1010, [2015] IRLR 43.

ibid, [34]. 
Rights, the Supreme Court held in Akerman-Livingstone v Aster Communities Limited ${ }^{522}$ that in relation to section 15, the 'substantive right to equal treatment protected by the Equality Act is different from the substantive right which is protected by article $8^{523}$ [of the European Convention of Human Rights]' 524 and that ' $[\mathrm{t}]$ his extra right is consistent with the obligations which the United Kingdom has now undertaken under the United Nations Convention on the Rights of Persons with Disabilities. ${ }^{525}$

\subsubsection{HARASSMENT}

Harassment related to disability is defined at section 26(1) of the EA 2010. This states:
A person (A) harasses another (B) if-
(a) A engages in unwanted conduct related to a relevant protected characteristic, and
(b) the conduct has the purpose or effect of-
(i) violating B's dignity, or
(ii) creating an intimidating, hostile, degrading, humiliating or offensive environment for B.

The wording employed by s26 EA 2010 borrows heavily from the Framework Directive. It also prohibits conduct 'related to a relevant protected characteristic' rather than requiring that the complainant possess the characteristic in questions. This covers associative and perceived harassment, thus ensuring compliance with both EU law and the CRPD. ${ }^{526}$

No justification for harassment is possible and no comparator is needed. However, in deciding whether conduct has the required effect, it must be asked whether it is reasonable for the conduct to have that effect (section 26(4)(c)). In other words, the fact that the claimant is peculiarly sensitive to the treatment accorded him or her does not necessarily mean that the treatment will amount to harassment. In addition, the definition of harassment expressly encompasses conduct 'related to' the protected characteristic, rather than the complainant's own possession of that characteristic and thus will cover associative ${ }^{527}$ and perceived discrimination. ${ }^{528}$

[2015] UKSC 15, [2015] AC 1399.

Article 8 provides a right to respect for one's private and family life, home and correspondence.

ibid [25].

ibid, [26].

See English v Thomas Sanderson Blinds [2008] EWCA Civ 1421, [2009] 2 All ER 468.

Coleman v Attridge Law [2010] 1 CMLR 28.

Chief Constable of Norfolk v Coffey [2017] UKEAT 0260_16_1912, [2018] I.R.L.R. 193. 


\subsubsection{VICTIMISATION}

Section 27 of the EA 2010 provides:

(1) A person (A) victimises another person (B) if A subjects B to a detriment because-

(a) B does a protected act, or

(b) A believes that B has done, or may do, a protected act.

(2) Each of the following is a protected act-

(a) bringing proceedings under this Act;

(b) giving evidence or information in connection with proceedings under this Act;

(c) doing any other thing for the purposes of or in connection with this Act;

(d) making an allegation (whether or not express) that A or another person has contravened this Act.

Thus, in the anti-discrimination legislation victimisation does not have its normal everyday meaning. It does not necessarily mean harassing or singling out somebody. Therefore, it is victimisation to punish an employee because they have complained about discrimination in some way, perhaps verbally, in a letter, in a written grievance or in a Tribunal case. A person may be victimised for giving evidence that another person has been discriminated against. ${ }^{529}$

Put simply, for a victimisation case to succeed, an employee will need to demonstrate that they have sought to enforce their rights under the EA 2010 and have been subjected to a detriment as a result. For example, they were disciplined, dismissed, refused promotion, denied overtime or made redundant.

Following the passage of the Equality Act, there was initially some confusion as to whether section 27 applied to victimisation that had occurred after the ending of the employment relationship. ${ }^{530}$ However, the influence of the Framework Directive and the CJEU on domestic law was displayed in Jessemey $v$ Rowstock Ltd \& Davis ${ }^{531}$. Here, the Court of Appeal expressly referred to the CJEU ${ }^{532}$ decision of Coote $v$ Granada Hospitality Ltd, ${ }^{533}$ where the CJEU decided a reference from the Employment Appeal Tribunal involving a case of alleged victimisation concerning a former employee who had brought a claim of sex discrimination. Although 
discrimination on the ground of sex was proscribed under the Equal Treatment Directive, this did not expressly refer to victimisation. The Court held that the Directive would be 'deprived of an essential part of its effectiveness if the protection which it provides did not cover measures which, as in the main proceedings in this case, an employer might take as a reaction to legal proceedings brought by an employee with the aim of enforcing compliance with the principle of equal treatment. ${ }^{, 534}$ Consequently, in Jessemey v Rowstock Ltd \& Davis the Court of Appeal came to the conclusion that, " $[\mathrm{i}] \mathrm{t}$ is clear from the decision of the ECJ in Coote that that provision must apply equally to acts done after as well as during the currency of the employment relationship. ${ }^{535}$

There is now no other reason to doubt that section 27 fails to comply with the Framework Directive and, in addition, it would appear compliant with the United Nations CRPD.

\subsubsection{DUTY TO MAKE REASONABLE ADJUSTMENTS}

The Code of Practice on Employment issued by the Equality and Human Rights Commission describes the duty to make reasonable adjustments as:

...a cornerstone of the Act which requires employers to take positive steps to ensure that disabled people can access and progress in employment. This goes beyond simply avoiding treating disabled workers, job applicants and potential job applicants unfavourably and means taking additional steps to which non-disabled workers and applicants are not entitled. ${ }^{536}$

The duty to make reasonable adjustments is found in section 20 of the EA $2010 .^{537}$ This contains a similar obligation as the pre-existing duty found at section 4A of the DDA $1995 .{ }^{538} \mathrm{As}$ a result, prior case law continues to be of relevance. ${ }^{539}$ Section 20(2) of the EA 2010 provides that the

For discussion of the duty from a domestic perspective see A. Lawson, 'Duties to Make Adjustments and Human Rights' in A Lawson (ed), Disability and Equality Law in Britain: The Role of Reasonable Adjustment (Hart Publishing, 2008); M Bell, 'Mental Health at Work and the Duty to Make Reasonable Adjustments' (2015) 44 (2) Industrial Law Journal 194.

For discussion of the duty from an EU perspective see L Waddington, 'Reasonable Accommodation' in D Schiek, L Waddington and M Bell (eds), Cases, Materials and Text on National, Supranational and International NonDiscrimination Law (Hart Publishing, 2007). 40 (4) Industrial Law Journal 359, 368. 194, 199.
} 
duty to make reasonable adjustments consists of three requirements. These being detailed at section 20(3), 20(4) and 20(5) EA 2010 as follows:

(3)The first requirement is a requirement, where a provision, criterion or practice of A's puts a disabled person at a substantial disadvantage in relation to a relevant matter in comparison with persons who are not disabled, to take such steps as it is reasonable to have to take to avoid the disadvantage.

(4)The second requirement is a requirement, where a physical feature puts a disabled person at a substantial disadvantage in relation to a relevant matter in comparison with persons who are not disabled, to take such steps as it is reasonable to have to take to avoid the disadvantage.

(5)The third requirement is a requirement, where a disabled person would, but for the provision of an auxiliary aid, be put at a substantial disadvantage in relation to a relevant matter in comparison with persons who are not disabled, to take such steps as it is reasonable to have to take to provide the auxiliary aid.

In relation to section 20(3) EA 2010 the words 'Provision, criterion or practice' are not defined by the Act, but the accompanying Code of Practice issued by the Equality and Human Rights Commission states that they, 'should be construed widely so as to include, for example, any formal or informal policies, rules, practices, arrangements or qualifications including one-off decisions and actions. ${ }^{940}$ Put simply, the first requirement relates to adjustments to intangible items such as company policies and procedures. The second relates to adjustments to tangible items such as buildings or physical structures. The third relates to the provision of items in order to provide the disabled individual with as 'level a playing field' as possible.

The earlier DDA 1995 gave guidance as to which factors were relevant in deciding whether it was reasonable for an employer to have to take a step in order to comply with the duty. ${ }^{541}$ These provisions were not re-enacted in the EA 2010 but the Code of Practice on Employment contains a much briefer checklist. It states:

The following are some of the factors which might be taken into account when deciding what is a reasonable step for an employer to have to take:

- whether taking any particular steps would be effective in preventing the substantial disadvantage;

- $\quad$ the practicability of the step;

\footnotetext{
540 Equality and Human Rights Commission, 'Employment Statutory Code of Practice' (Equality and Human Rights 2011), para 6.10.

$541 \quad$ s18B(1) DDA 1995
} 
- the financial and other costs of making the adjustment and the extent of any disruption caused;

- the extent of the employer's financial or other resources;

- the availability to the employer of financial or other assistance to help make an adjustment (such as advice through Access to Work); and

- the type and size of the employer. ${ }^{542}$

However, it is worth remembering that ultimately the test of the 'reasonableness' any step an employer may have to take is an objective one and will depend upon the individual circumstances of each particular case. Thus, in Cordell v Foreign and Commonwealth Office ${ }^{543}$ the Employment Appeal Tribunal considered whether an employer's refusal to provide lipspeaking support to a deaf employee was unreasonable based on cost alone. The cost of providing the support would have been at least $£ 249,500$ per year. It found that such cost made the adjustment unreasonable.

Such an approach is consistent with the CRPD as Article 5, paragraph 3 only obliges States Parties to provide 'reasonable accommodation'. In a similar vein, Article 5 of the Framework Directive provides that a measure would not be reasonable if it "would impose a disproportionate burden on the employer.' In addition, Recital 21 of the Framework Directive provides that:

To determine whether the measures in question give rise to a disproportionate burden, account should be taken in particular of the financial and other costs entailed, the scale and financial resources of the organisation or undertaking and the possibility of obtaining public funding or any other assistance.

Indeed, Fredman notes that costs 'constitute the hidden but powerful agenda behind much of equality policy and legislation. ${ }^{544}$ In contrast, in the context of the accommodation duty outline in the CRPD, Broderick categorises cost as representing one of the 'outer limits' of the duty to accommodate. ${ }^{545}$ Equality and Human Rights Commission, 'Employment Statutory Code of Practice’ (Equality and Human Rights 2011), para 6.28. 
Section 20 of the EA 2010 only requires a reasonable adjustment where there is a 'substantial disadvantage', in considering those words the Court of Appeal in Newham Sixth Form College v Sanders ${ }^{546}$ Lord Justice Laws stated:

In my judgment these three aspects of the case - nature and extent of the disadvantage, the employer's knowledge of it and the reasonableness of the proposed adjustments necessarily run together. An employer cannot, as it seems to me, make an objective assessment of the reasonableness of proposed adjustments unless he appreciates the nature and the extent of the substantial disadvantage imposed upon the employee by the PCP. ${ }^{547}$

Yet the use of the word 'substantial' means it is apparent that it is not correctly aligned with the CRPD. In the Convention, reasonable accommodation is defined at Article 2 as:

Reasonable accommodation means necessary and appropriate modifications and adjustments not imposing a disproportionate or undue burden, where needed in a particular case, to ensure to persons with disabilities the enjoyment or exercise on an equal basis with other of all human rights and fundamental freedoms.

Whilst Article 5(3) states:

In order to promote equality and eliminate discrimination, States Parties shall take all appropriate steps to ensure that reasonable accommodation is provided.

There is similarly no requirement for an individual to be placed at a 'substantial' disadvantage in Article 5 of the Framework Directive. ${ }^{548}$ If a rights-based approach is utilised, the substantiality requirement in section 20 should not stand; indeed if any curtailing of the right to reasonable accommodation is to be made, then it should solely be the fact that any accommodation is subject to it not imposing a disproportionate or undue burden. ${ }^{549}$ The requirement for the disadvantage to be substantial imposes an additional restriction on the ability of individuals with disabilities to be afforded reasonable adjustments when compared to the CRPD and EU law.

[2014] EWCA Civ 734, [2014] All ER (D) 87

ibid, [14].

See section 3.4.2 for the wording, and a discussion, Article 5 (3) of the Framework Directive.

S Fraser Butlin, 'The UN Convention on the Rights of Persons with Disabilities: Does the Equality Act 2010 Measure up to UK International Commitments?’ (2011) 40 (4) Industrial Law Journal 428. 
As noted by the House of Lords in Archibald v Fife Council ${ }^{550}$ the duty imposed under domestic legislation sometimes requires the disabled individual to be treated more favourably in order to minimise any potential disadvantage they may suffer. Although this was a case decided under the earlier DDA 1995 the principles remain the same, hence it is not just a matter of introducing a level playing field because that approach ignores the fact that disabled individuals require assistance if they are to be able to compete on equal terms with those who are not disabled. Therefore, according to Baroness Hale:

[T]his legislation is different from the Sex Discrimination Act 1975 and the Race Relations Act 1976. In the latter two, men and women or black and white, as the case may be, are opposite sides of the same coin. Each is to be treated in the same way. Treating men more favourably than women discriminates against women. Treating women more favourably than men discriminates against men. Pregnancy apart, the differences between the genders are generally regarded as irrelevant. The 1995 Act, however, does not regard the differences between disabled people and others as irrelevant. It does not expect each to be treated in the same way. It expects reasonable adjustments to be made to cater for the special needs of disabled people. It necessarily entails an element of more favourable treatment. ${ }^{551}$

Despite all this, according to NAM: Aidsmap the adjustments that most HIV-positive employees request tend to be quite straightforward and easy to accommodate which accordingly means they are more likely to be reasonable in the eyes of the law. ${ }^{552}$ Commonly requested adjustments include needing to attend occasional clinic appointments during working hours, adjustments to hours as result of needing to take medication at set times and assistance in coping with side effects, especially when a new treatment regime is started. ${ }^{553}$

Yet it is always worth remembering that as a consequence of Schedule 8, paragraph 20(1)(b) of the EA 2010, an employer only has a duty to make an adjustment if they know, or could reasonably be expected to know, that a worker has a disability and is, or is likely to be, placed at a substantial disadvantage. In addition, as the EA 2010 does not prevent a disabled individual keeping their condition confidential, the employer may not be under a duty to make a reasonable adjustment. ${ }^{554}$ As Waddington and Broderick observe:

where an individual with an invisible disability discloses her or his disability, the person may risk exposure to additional discrimination, disadvantage and prejudice.

[2004] UKHL 32, [2004] 4 All ER 303.

ibid, [47].

NAM: Aidsmap, 'Social and Legal Issues for People with HIV' (NAM Aidsmap 2010).

ibid.

See also section 3.4.2 for further commentary regarding the knowledge that an employer must have. 
Therefore, individuals may feel uncomfortable revealing that they have a disability. However, non-disclosure means that they will not be able to access the reasonable accommodation that they may need. ${ }^{555}$

This places PLHA in somewhat of a dilemma. Either keep their diagnosis private and attempt to remain in employment without the benefit of reasonable adjustments, or disclose to their employer but risk being subjected to stigma, discrimination and potentially, the ending of their employment. To some this may sound implausible but one only has to recall the work of Fesko discussed in Chapter 1.5. ${ }^{556}$ Individuals who spoke to Fesko identified stigma as being a key factor in their decision to disclose, with one man describing it as follows:

It's like protecting yourself, a safety mechanism to being silent, and like I said, if there is no absolute reason, why put yourself in jeopardy? Rocking the boat when you don't need to. ${ }^{557}$

Fesko also discovered that the most frequently cited reasons for disclosing HIV status were to explain choices made whilst interviewing for a job, explaining changes in workplace performance and requesting that adjustments be made to their job or working environment. This leads to the somewhat inevitable conclusion that PLHA who disclose in a workplace setting usually do so as a consequence of economic forces and not their own free will.

To counter this issue of non-disclosure, employers are required to take steps to ascertain whether an individual has a disability. ${ }^{558}$ Indeed, the Equality and Human Rights Commission's Code of Practice on Employment states:

For disabled workers already in employment, an employer only has a duty to make an adjustment if they know, or could reasonably be expected to know, that a worker has a disability and is, or is likely to be, placed at a substantial disadvantage. The employer must, however, do all they can reasonably be expected to do to find out whether this is the case. ${ }^{559}$

L Waddington and A Broderick, Promoting Equality and Non-Discrimination for Persons with Disabilities' (Council of Europe 2017) 20. S Fesko, 'Disclosure of HIV status in the workplace: considerations and strategies' (2001) 26 (4) Health \& Social Work 235 . ibid, 239.

See section 7.3 for further discussion of this point Equality and Human Rights Commission, 'Employment Statutory Code of Practice' (Equality and Human Rights Commission 2011), para 6.19.
} 
What is reasonable will depend on the circumstances and is an objective assessment. ${ }^{560}$ However, in relation to PLHA this may prove problematic. First, as treatments for PLHA improve, HIV positive individuals within an employment relationship are no more likely to be absent from work due to ill health than any other employed person. ${ }^{561}$ This coupled with HIV's invisibility presents challenges to employers seeking to ascertain their employee's HIV status. The result is that employers can only usually ascertain an individual's HIV status as a result of further investigations. These investigations will inevitably be perceived as invasions of privacy by PLHA. Thus, as one individual stated to Fesko:

I still feel like it is personal. My work has nothing to do with my health status as long as I am performing my job and doing what I am supposed to do. I really don't think that is important for them to know. ${ }^{562}$

They may also breach the employee's right to privacy and the implied term of mutual trust and confidence within the employment relationship. As a consequence of the above, the duty to make reasonable adjustments may, as far as PLHA are concerned, be perceived as akin to a 'legal no-man's land'. Whilst some have been happy to disclose their status and have adjustments made, others living in fear of stigma and discrimination choose not to disclose and continue the employment relationship in a somewhat disadvantaged position. Any attempt by the employer to cross this no-man's land and investigate an employee's perceived disability may be seen as an invasion of privacy by the employee.

By way of comparison, in non-employment areas (other than premises) the duty to make reasonable adjustments is anticipatory in nature as opposed to reactive. For example, service providers are required to monitor the services or functions they provide on an ongoing basis in order to anticipate any potential disadvantage which may be caused to disabled individuals by their provisions, criteria or practices, by their physical features, or by their auxiliary aid or service provision. ${ }^{563}$ If any disadvantage can be anticipated, service providers are required to take reasonable steps to remove such disadvantage even if no disabled person has actually yet been disadvantaged. The duties also have a reactive element as service providers are required to take reasonable steps to remove a disadvantage once they become aware that a disabled individual is being disadvantaged in accessing their services. Lawson argues that these anticipatory duties have a much greater potential to drive systemic change than the present

\footnotetext{
$560 \quad$ idid.

$561 \quad$ J Leigh and others, 'Absenteeism and HIV infection' (1997) 4 (5) Applied Economics Letters 275; James Habyarimana, Bekezela Mbakile and Cristian Pop-Eleches, 'The Impact of HIV/AIDS and ARV Treatment on Worker Absenteeism: Implications for African Firms' (2010) 45 Journal of Human Resources 4. S Fesko, 'Disclosure of HIV status in the workplace: considerations and strategies' (2001) 26 (4) Health \& Social Work 235, 239.

563 Schedule 2 of the Equality Act 2010.
} 
reactive employment duty. ${ }^{564}$ The use of a reactive duty within employment has the potential to improve access to, and opportunities within, employment for not only PLHA but numerous individuals within the workplace and break the current uneasy truce which is of questionable benefit to employers and employees. By way of example, the use of a reactive duty might prompt a workplace to move away from fixed working hours, of for instance 9 am to $5 \mathrm{pm}$ on weekdays and as an alternative offer all individuals the opportunity to work flexible hours. Such a move would benefit PLHA by allowing them the opportunity to attend scheduled hospital appointments on weekdays. ${ }^{565}$ It would also benefit working parents and enable them to better manage their childcare responsibilities by, for example, providing them with the opportunity of taking or leaving their children at school during the week.

It is for this reason that the issue of reasonable adjustments and PLHA's experiences of the same is an issue that will be specifically addressed by the empirical research part of this thesis. In particular, participants to the empirical research will be questioned regarding their awareness of reasonable adjustments and, for those with awareness of the concept, the factors they took into account in deciding whether or not to request reasonable adjustments from their employer.

\subsubsection{CONCLUSION}

In two areas the manner in which PLHA are protected by the EA 2010 fails to comply with relevant EU and international law. These are first, the EA 2010's failure to prohibit multiple discrimination and second, the manner in which the duty to make reasonable adjustments has been formulated by the EA 2010.

The concept of multiple discrimination has its roots in the concept of intersectionality developed by the American academic Kimberlie Crenshaw. ${ }^{566}$ Intersectionality means paying attention to how multiple social forces, such as race, class, gender, age, sexuality, and culture, shape individual's experiences of discrimination. ${ }^{567}$ This in turn has shaped global legal approaches to discrimination. By way of example, Article 6 of the CRPD recognises that women and girls with disabilities are subject to multiple discrimination whilst the Convention's preamble also expresses States Parties concerns about multiple discrimination. ${ }^{568}$ The EA 2010's provision in

A Lawson, 'Disability and Employment in the Equality Act 2010: Opportunities Seized, Lost and Generated' (2011) 40 (4) Industrial Law Journal 359.

12-weekly hospital appointments are standard for PLHA. See British HIV Association, ‘ British HIV Association guidelines for the routine investigation and monitoring of adult HIV-1-positive individuals 2016' (BHIVA 2016).

Kimberle Crenshaw, 'Demarginalizing the Intersection of Race and Sex: A Black Feminist Critique of Antidiscrimination Doctrine, Feminist Theory and Antiracist Politics' [1989] University of Chicago Legal Forum, 139. M Deckha, 'Is culture taboo? Feminism, Intersectionality and Culture Talk' (2004) 16 (1) Canadian Journal of Women and the Law, 672 . ibid.
} 
relation to this concept appears at section 14 where the intention is to tackle tackle situations where discrimination arises out prejudice or assumptions specific to a combination of factors. Yet, at the time of writing whilst the majority of the EA 2010 has been brought into force, section 14 has not. Indeed despite the apparent benefits of the section the Chancellor of the Exchequer, George Osborne, announced in the 2011 Budget that the section would not be brought into force as it would place an unnecessary regulatory burden on employers. ${ }^{569}$ This is a matter of concern and for this reason PLHA's experiences of intersectional discrimination will be examined from an empirical perspective in Chapters 6 and 7. If it is apparent that intersectional discrimination is a matter of concern for PLHA it will be recommended in the conclusion to this thesis that section 14 of the Act be brought into force.

In the employment arena the scope of the duty to make reasonable adjustments has been curtailed. This means that in in employment the duty to make reasonable adjustments is reactive, whereas in non-employment areas (other than premises) ${ }^{570}$ the duty imposed by section 20 to make reasonable adjustments is anticipatory in nature as opposed to reactive. Although the approach taken by the Act with regards to reasonable adjustments in employment is compliant with the UK's international and European legal obligations, it is submitted that the use of an anticipatory duty would be preferable, and this shall be returned to and expanded upon in the Conclusion to this thesis. Of more concern is the Act's requirement for individuals with disabilities to be placed at a 'substantial disadvantage' before their employer is placed under a duty to make reasonable adjustments. Such an approach fails to comply with the UK's obligations under Article 2 of the UN CRPD and Article 5 of the Framework Directive as neither instrument requires individuals with disabilities to be placed at a 'substantial' disadvantage and the requirement for the disadvantage to be substantial imposes an additional restriction on the ability of individuals with disabilities to be afforded reasonable adjustments.

Also of concern is the manner in which popular myths regarding the transmissibility and risk of HIV were accepted by the court in High Quality Lifestyles $v$ Watts. However, discussion and analysis of this case helped ascertain areas of relevance in formulating questions for the empirical research part of this thesis. In High Quality Lifestyles, Watts was subject to discrimination once he had disclosed his HIV status to this employer. Consequently, it is apparent that PLHA's experiences of disclosure is an area of potential difficulty; therefore, this is an area that will be explored in detail with the participants in the empirical research associated with this thesis. The investigation will include discussion of the factors enabling disclosure in employment relationships, in addition to factors preventing disclosure. It is also apparent from the doctrinal research undertaken that, as discussed in section 4.3.7, the duty to make reasonable adjustments only applies to employers if they have knowledge of an individual's disability. 
Placing the employer under this duty may form part of PLHA's decision making process when deciding whether or not to disclose their HIV status to their employer and so, participants taking part in the empirical research will also be questioned about their level of awareness of the current legal framework relating to HIV and, more specifically, the concept of reasonable adjustments.

Finally, as Watts discovered in High Quality Lifestyles, PLHA are protected in the EA 2010 by the concept of disability. Yet Watts was only 30 years of age at the time and in fact the majority of PLHA in the UK are below 50 years of age. ${ }^{571}$ Given the relatively young age of these individuals now being classified as disabled by the EA 2010, participants to the empirical research will also be questioned regarding their attitudes and thoughts on being classified as disabled by the Act. Indeed, having discussed the relevant case law and the manner in which the EA 2010 protects PLHA from discrimination in this chapter, the focus of this thesis will turn in the next chapter to a consideration of why the decision was taken to classify HIV as a ‘disability' for the purposes of UK discrimination law. 


\section{CHAPTER 5: HIV AS A DISABILITY}

\section{$5.1 \quad$ INTRODUCTION}

This chapter will illustrate the reasons why the UK has taken a different approach to protecting People living with HIV or with AIDS (PLHA) to that taken by both EU and international law. This will be done through analysis of the consultation exercise and parliamentary proceedings surrounding the passage of the relevant legislation which, in addition, will assist in formulating questions for the empirical study. The chapter will demonstrate that the decision to deem HIV a disability was heavily influenced by the stigma affecting PLHA, which was a factor specifically mentioned by Parliamentarians during the legislation's passage. Finally, the conclusion will summarise the analysis of the chapter and set out questions arising from this chapter that are to be addressed in the empirical research.

Whilst legislation to protect individuals against discrimination on the basis of sex and race was introduced in the $1970 \mathrm{~s},{ }^{572}$ individuals with disabilities were not protected from discrimination until the introduction of the Disability Discrimination Act 1995 (DDA 1995). As shall be detailed in section 5.2, under the DDA 1995 as originally drafted PLHA were only protected if they were symptomatic. However, in an attempt to increase the scope of protection and overcome discrimination against PLHA, Parliament took the step of classifying HIV as a 'disability' from the point of diagnosis and therefore afforded PLHA with protection under the DDA $1995 .^{573}$

The employment provisions were to be found in Part II of the DDA 1995 and from 6 December 2005, persons diagnosed with cancer, HIV and multiple sclerosis were deemed to suffer from a disability and hence be a disabled person, irrespective of whether they exhibited symptoms of their disease. ${ }^{574}$ This chapter will examine the background to and reasons for this legislative amendment to the DDA 1995.

\subsection{THE DISABILITY RIGHTS TASK FORCE}

In December 1997, the then Labour Government established the Disability Rights Task Force (DRTF). ${ }^{575}$ The DRTF consisted of 24 members drawn from the disability field, business, trades

\footnotetext{
Sex Discrimination Act 1975; Race Relations Act 1976.

Disability Discrimination Act 2005, s 18.

By way of amendement to paragraph 6A, Schedule 1 Disability Discrimination Act 1995.

Ian Smith and Aaron Baker, 'Smith \& Wood's Employment Law' (12th edn, Oxford University Press 2015$) 410$.

Its members were: Chair: Margaret Hodge MP - Minister for Disabled People, Stephen Alambritis - Federation of Small

Businesses, Bob Benson - Disability Scotland, Jane Campbell - National Centre for Independent Living, Elizabeth
} 
unions and local authorities. ${ }^{576}$ For the majority of its life it was chaired by Margaret Hodge, Minister for Disabled People (having been chaired initially by the previous Minister for Disabled People, Alan Howarth). ${ }^{577}$

The DRTF's objective was to examine the range of issues that affected disabled people's lives and advise the Government on what further action it should take to promote comprehensive and enforceable civil rights for disabled people. Its formal terms of reference were:

To consider how best to secure comprehensive, enforceable civil rights for disabled people within the context of our wider society, and to make recommendations on the role and functions of a Disability Rights Commission. To provide the latter by March 1998 and to provide a full report of its recommendations on wider issues no later than July 1999. 578

The first task of the DRTF was to develop proposals to establish a Disability Rights Commission (DRC). ${ }^{579}$ The DRTF felt that the lack of an enforcement body, responsible for ensuring compliance with disability rights legislation was one of the greatest flaws in the DDA 1995. ${ }^{580}$ Consequently, the DRC was to assume these responsibilities when it was established in April 2000..$^{581}$

In 1999, the DRTF published its report 'From Exclusion to Inclusion'582 in which the taskforce considered a range of issues affecting the lives of disabled people including education,

Clarke - former Business Research Officer Institute of Directors, Caroline Gooding - Trade Union Disability Alliance, David Grayson - National Disability Council, Rachel Hurst - Rights Now, David Jenkins - Wales Trade Union Council, Su Jenkins - Member, Confederation of British Industry, Brian Lamb - SCOPE, Colin Low - Royal National Institute of the Blind, Joe Mann - National League for the Blind and Disabled, Bert Massie - The Royal Association for Disability and Rehabilitation, Brian Pomeroy - Deloitte and Touche Consulting Group, Philippa Russell - Council for Disabled Children, Liz Sayce - former Policy Director, Mind (National Association for Mental Health, Susan Scott-Parker Employers' Forum on Disability, Ranjit Sondhi - former Deputy Chairman, Commission for Racial Equality, James Strachan - The Royal National Institute for Deaf People, Richard Taylor - Lifespan Healthcare NHS Trust, Roy Taylor - Community Services, Kingston-upon-Thames Local Authority, Keith Welton - Mid Yorkshire Chamber of Commerce and Industry Ltd, Monica Wilson - Disability Action (Northern Ireland), Richard Wood - British Council of Organisations of Disabled People.

Disability Rights Task Force, 'From exclusion to inclusion: final report of the Disability Rights Task Force' (Department for Work and Pensions 1999) 197.

ibid.

Disability Rights Task Force, 'From exclusion to inclusion: final report of the Disability Rights Task Force' (Department for Work and Pensions 1999), 2.

ibid, 5 .

ibid.

Ian Smith and Aaron Baker, 'Smith \& Wood's Employment Law' (12th edn, Oxford University Press 2015) 410.

Disability Rights Task Force, 'From exclusion to inclusion: final report of the Disability Rights Task Force' (Department for Work and Pensions 1999). 
employment and travel amongst other areas. It also made recommendations to achieve comprehensive and enforceable civil rights for disabled people.

The DRTF specifically examined the definition of disability employed by the DDA 1995 at the time and noted that it had significant flaws. In relation to HIV, the DRTF noted that there was a significant deficiency with regard to individuals with asymptomatic HIV. ${ }^{583}$ This arose as a result of the manner in which the DDA 1995 dealt with individuals who had, what were termed, progressive conditions. The relevant legislation was to be found in paragraph 8 of Schedule 1 of the original (unamended) DDA 1995. This stated:

Progressive conditions

8 (1) Where -

(a) a person has a progressive condition (such as cancer, multiple sclerosis or muscular dystrophy or infection by the human immunodeficiency virus),

(b) as a result of that condition, he has an impairment which has (or had) an effect on his ability to carry out normal day-to-day activities, but

(c) that effect is not (or was not) a substantial adverse effect, he shall be taken to have an impairment which has such a substantial adverse effect if the condition is likely to result in his having such an impairment.

(2) Regulations may make provision, for the purposes of this paragraph-

(a) for conditions of a prescribed description to be treated as being progressive;

(b) for conditions of a prescribed description to be treated as not being progressive.

Thus, although separate provision was made for progressive conditions giving rise to a qualifying disability, there was a tendency by courts and tribunals to interpret this aspect of the legislation strictly with the result that those with such conditions but whose symptoms were limited might not qualify. Consequently, simply having the condition was not sufficient to ensure an individual fell within the definition, instead an individual had to demonstrate that their condition in some way impacted upon their ability to carry out normal day-to-day activities and that the effect on that ability was likely to be substantial in the future. The deficiencies of this approach were illustrated by the decision of the Employment Appeal Tribunal in Mowat-Brown $v$ University of Surrey ${ }^{584}$. In this case, Dr Mowat-Brown was employed as a lecturer in music by the University of Surrey from October 1981 until 30 September 1998 under a series of contracts. In 1995, he began to have acute manifestations of what was subsequently diagnosed as multiple sclerosis. At the time, he was engaged under a contract whereby he undertook duties equating to $55 \%$ of an equivalent full-time contract. Following the amalgamation of his department with another, he was relieved of administrative and research duties for the academic 
year commencing 1 October 1988 and only offered a contract amounting to $20 \%$ of an equivalent full-time contract. He declined the offer and brought claims for disability discrimination and unfair dismissal against the University. The central legal issue in the case was whether Dr Mowat-Brown was a disabled person within the meaning of section 1 of the DDA 1995. The definition of disability under section 1 of the DDA 1995 was in substantially the same terms as that now employed by section 6 of the EA 2010 and discussed in section 4.2.

The initial Employment Tribunal considered reports provided by Dr Mowat-Brown's GP, Dr Lane, and from Dr Bain, a consultant neurologist. Dr Lane's report stated, 'He has very few symptoms and his disease seems to have troubled him very little. In fact his multiple sclerosis seems quite quiescent. ${ }^{585}$ The report from Dr Bain stated, 'Presently, he is not disabled by the condition and is fit for work. Unfortunately, it is not possible to give an accurate prognosis for any individual with multiple sclerosis because of the variable nature of the condition. The absence of any abnormal signs, three years after his presentation to me, provides grounds for some optimism about his future. ${ }^{586}$ The tribunal said that it regarded Dr Mowat-Brown's evidence that he had weakness of the limbs and poor coordination as vague and unconvincing and went on to decide that his case did not fall within the definition of progressive conditions in paragraph 8(1) of Schedule 1 to the DDA. The initial employment tribunal thus concluded that Dr Mowat-Brown did not fall within the definition.

On appeal, it was argued on behalf of Dr Mowat-Brown that the initial employment tribunal's conclusion was wrong in law. Counsel for Dr Mowat-Brown submitted that the structure of paragraph $8(1)$ was such that the words 'likely to result' related to the particular medical condition in question rather than the particular applicant, and that the approach taken by the initial tribunal would remove many people with multiple sclerosis from the potential protection of the paragraph if each applicant had to produce a diagnosis to the effect that future substantial effects were more probable than not in their case. Counsel further submitted that the question should be decided on a condition-by-condition basis, which might involve a statistical approach in the light of the particular disease and the known facts about the individual applicant. For the majority of MS sufferers with the relapsing-remitting form of the disease it would mean asking whether or not most people with that condition eventually experience some substantial effects on normal day-to-day activities.

The Employment Appeal Tribunal rejected this argument and held that the initial Employment Tribunal was entitled to find that the applicant's case did not fall within the definition of a 'progressive condition'. In order to determine whether an individual's case fell within the definition relating to progressive conditions, the EAT was of the opinion that the question to be 
asked was whether, on the balance of probabilities, the individual had established that the condition in their particular case was likely to have a substantial adverse effect. It was not enough simply for an individual to establish that they had a progressive condition and that it had or previously had had an effect on their ability to carry out normal day-to-day activities. A claimant must demonstrate that it was more likely than not that at some stage in the future their impairment would have a substantial adverse effect upon their ability to undertake normal dayto-day activities. Indeed, Judge Reid QC stated that:

The claimant must go on and show that it is more likely than not that at some stage in the future he will have an impairment which will have a substantial adverse effect on his ability to carry out normal day-to-day activities. How the claimant does this is up to him. In some cases, it may be possible to produce medical evidence of his likely prognosis. In other cases, it may be possible to discharge the onus of proof by statistical evidence. ${ }^{587}$

On the evidence before them, the Employment Appeal Tribunal was of the opinion that there was no relevant statistical evidence and that the medical evidence relating to the applicant entitled the initial Tribunal to find he was not currently disabled for the purposes of the DDA 1995 and that it was not more likely than not that in the future the condition would have a substantial adverse effect on his ability to carry out day-to-day activities. Thus, for PLHA wishing to make a claim under the DDA 1995, the question of 'disability' was to be established by reference to their own prognosis and not to a normative understanding of what effects HIV might typically have upon an individual in the future. As one legal specialist involved in DDA litigation made clear:

[T]he definition of likely was more probably than not. That gave rise to real problems...Even if you can show that more than 50 per cent of people with [HIV] go on to develop a substantial and long-term adverse effect from it...that didn't necessarily help you, because the tribunals and courts were saying, 'well, we don't just want to know whether statistically that condition leads to that. We want to know in the case of your client, does your client fall into the 51 per cent who will go on to have substantial and long term effects or are they in the 49 per cent? $?^{588}$

According to Grabham, the effect of the Mowat-Brown decision was that priority was attached to an individual's personal, 'prognosis and lifespan over a population level understanding of the progression of disease based on statistical likelihood. ${ }^{589}$ Thus, this made it almost impossible

ibid 238 .

Emily Grabham, Brewing Legal Times: Things, Form, and the Enactment of Law (University of Toronto Press 2016)

111.

ibid. 
for individuals with progressive conditions to satisfy the definition of disability due to the inevitable difficulty of medical experts being able to predict, on the civil standard of proof, whether a particular individual's impairment would be likely to have a substantial adverse effect upon their ability to carry out normal day-to-day activities in the future. In recognition of the difficulties the decision might cause for individuals with asymptomatic HIV infection, when considering the definition of disability employed by the DDA 1995 at the time the DRTF noted:

We were aware that our role was not to specify the words that would be used in any future civil rights legislation to define disability: that is the role of Parliament. We focused on addressing real-life examples of disabled people who are inadequately or unclearly protected, or not protected at all, by the current DDA definition.

\section{Asymptomatic HIV}

6. The DDA definition does not cover people with progressive conditions before they have symptoms ('asymptomatic')...

7. People with the HIV infection sometimes attract fear and prejudice, which affects their lives from when their HIV status is known about, even if there are no symptoms and though there is no risk of transmission from normal contact. Estimates suggest that there are fewer than 20,000 people with asymptomatic HIV. Their coverage would represent an increase of just $0.2 \%$ in the numbers of people protected by the DDA.

8. We further considered whether people with asymptomatic HIV should be covered from the point at which significant treatment is likely or from the point of diagnosis. Given that people in this position, with the current state of medical knowledge, are likely to require significant treatment at some time in their lives, coverage should be from the point of diagnosis as this provides more certainty about when protection begins. ${ }^{590}$

This observation by the DRTF illustrates that the primary concern in relation to PLHA was not the possible effect the virus might have upon an individual's ability to undertake normal dayto-day activities at some point in the future, but rather the stigma which affects the lives of PLHA even when no symptoms are present. In light of this the DRTF recommended:

3.2 HIV infection should be deemed a disability from the point at which it is diagnosed. ${ }^{591}$ 
In 2001 the Government published 'Towards Inclusion-civil rights for disabled people'. 592 This was the Government's response to the Disability Rights Task Force recommendations and the Government responded by saying, 'We will ensure that HIV infection counts as a disability from the time at which it is diagnosed.'

In conclusion, the establishment of the DRTF meant that consideration took place as how best to provide comprehensive civil rights for all individuals with disabilities. As part of this exercise, the DRTF noted that individuals with progressive conditions were disadvantaged due to the restrictive interpretation of the definition of progressive conditions. It was also specifically noted that PLHA were subject to stigma and prejudice even though there was no risk of transmission from normal contact and even where PLHA experienced no symptoms associated with the virus. This led the DRTF to propose that HIV be deemed a disability from the point of disability. This proposal was accepted by the Government who then proceeded to undertake a consultation exercise, the responses to which will now be discussed and analysed.

\subsection{THE CONSULTATION EXERCISE}

Following its response to the DRTF's recommendations, the Government launched a consultation exercise to seek, 'as a basis for further action, the views of disabled people, disability organisations, employers, service providers and others on the way forward on some specific legislative, and non-legislative, proposals. ${ }^{593}$ The questionnaire issued by the Government as part of this consultation exercise sought opinions on a number of the DRTF's recommendations. The first question asked was, 'Do you agree that HIV infection should count as a disability under the Disability Discrimination Act (DDA) from when it is diagnosed? ${ }^{594}$ Respondents to the consultation exercise were also free to add in additional comments in relation to their response. The second question asked was also related to the definition of disability. It asked, 'Do you agree that people with cancer should count as disabled under the DDA from the time the cancer is diagnosed as being likely to require substantial treatment? ${ }^{595}$

In order to obtain copies of responses to this consultation exercise, a number of requests were submitted under the Freedom of Information Act 2000 to the then relevant Government department, the Office for Disability Issues. Upon receipt of this information from the Office

Department for Education and Employment, 'Towards Inclusion - civil rights for disabled people' (Department for Education and Employment 2001).

$593 \quad$ ibid, 6

594 Department for Education and Employment, 'Towards Inclusion - Civil Rights for Disabled People - Questionnaire' (2001) < https://www.education.gov.uk/consultations/downloadableDocs/60_4.pdf> accessed 7 July 2016, 2 
for Disability Issues, it was discovered that a total of 207 responses were received which directly responded to the question, 'Do you agree that HIV infection should count as a disability under the Disability Discrimination Act (DDA) from when it is diagnosed?' Of the 207 respondents, 57 requested that their additional written responses to the exercise remained confidential. However, it is possible to ascertain that of these 57 individuals, 45 agreed with the question, 'Do you agree that HIV infection should count as a disability under the Disability Discrimination Act (DDA) from when it is diagnosed?', 8 disagreed and 4 expressed no view either way. Copies of the questionnaire responses from the 150 respondents who did not request that their written responses remain confidential were then sought from the Office for Disability Issues. The Office for Disability Issues located and supplied copies of these 150 responses. Of these 150 responses, 128 agreed with the proposal in relation to HIV, 16 disagreed and 6 expressed no view either way. Thus, in summary, of the 207 responses, 173 agreed that HIV should count as a disability from the point of diagnosis, 24 disagreed and 10 had no view either way.

However, some respondents, despite agreeing with the proposal, were somewhat cautious in their support. For example one respondent, the Equal Opportunities Officer of King's College London, responded to the questionnaire as follows: 'Making it this specific produces a ranking system which is not in line with the spirit of the legislation i.e. MS, Sickle Cell - other disabilities which are progressive would therefore be left out as not "named"'. In a similar vein, the Employment Law Committee of The Law Society responded:

We agree that [HIV and cancer] should qualify as disabilities from the point of diagnosis. However, there is a problem with including specified illnesses unless by way of example. There are other progressive illnesses which may be diagnoses before symptoms (which are sufficient to bring a person within the current definition) appear e.g. multiple sclerosis, muscular dystrophy. The definition should be broad enough to include all serious progressive illnesses.

Some respondents specifically commented upon the stigma associated with the virus and how the virus could be socially disabling. One respondent who did recognise this aspect of the virus commented that HIV should count as a disability from the point of diagnosis, '[d]ue to social constructed stigmas and that some adjustments may take place in order for individuals with HIV to participate in work, social and economic life. (sic) ${ }^{596}$ Another respondent commented that, ' $[\mathrm{t}]$ he stigma of being diagnosed HIV+ is enough to result in discrimination. I would very much welcome this extension of the DDA into the more social model. Attitudes are usually the biggest 
barriers for disabled people. ${ }^{597}$ Whilst the Disability Equality Officer of Bath \& Northeast Somerset Council responded:

As a council we have adopted a Disability Equality policy which reflects the social model of disability. This in practice will mean that we aim to recognise the social stigmas, and other barriers that people living with HIV may face in order to participate within the social and economic world.

Finally, Disability (Oxford) Ltd responded that, '[b]ecause of the fear factor associated with HIV, if someone wishes to inform their employer of their diagnosis they should be protected against discrimination as a result of the diagnosis and the decision to be public about it.'

Comments from those against the proposal were few in number. Claire Curtis-Thomas, then Labour Member of Parliament for Crosby, responded, 'HIV should not count as a disability until the condition manifestly excludes an individual from participating in the workplace.' A private individual responded 'I know people with HIV and they don't consider themselves disabled. ${ }^{598}$ This response fails to elaborate the reasons why this individual's acquaintances with HIV fail to consider themselves disabled however, one factor identified in section 4.4.2 was the relatively young age of PLHA as evidenced by the fact that the majority of PLHA in the UK are below 50 years of age. ${ }^{599}$ This contrasts with the common perception that individuals with disabilities are invariably old and the accepted correlation between age and disability. ${ }^{600}$ This further highlights the fact that there is a need for careful questioning with regard to PLHA's thoughts regarding being classified as disabled by the EA 2010.

Some responses to the consultation exercise, however, revealed the significant levels of stigma and prejudice that PLHA face. By way of example, a response from an organisation describing itself as The Damelea Association read as follows:

The answer to this also covers Cancer, however, I answer this in the following way: As this disease in the UK has been covered by most extensive publicity, it is very much a disease which is either self-inflicted or transmitted to healthy people by those infected. By the publicity on HIV (AIDS) and media publications on some one (sic) who has been sent to prison because of not informing the person that he had AIDS, this

Sue Jones. Described as 'an individual non-disabled person' by the Office for Disability Issues.

Barry Woodcock . Described as an 'Individual Disabled Person' by the Office for Disability Issues.

Public Health England, 'Progress towards ending the HIV epidemic in the United Kingdom: 2018 report' (Public Health England 2018), 30.

See M Sargeant, 'Older workers and the need for reasonable accommodation' (2008) 9 International Journal of Discrimination and the Law 163; M Wahrendorf, J Reinhardt and J Siegrist 'Relationships of Disability with Age Among Adults Aged 50 to 85: Evidence from the United States, England and Continental Europe' (2013) 8(8) PLoS One < https://www.ncbi.nlm.nih.gov/pmc/articles/PMC3743762/> accessed 7 March 2019. 
is felt to be a question which requires much thought. Thus it is thought it should not be treated as a disability under the Act from when it is first diagnosed.

Similarly, when asked whether HIV should be a disability, one individual responded that, 'It depends on how these people got it. ${ }^{\text {'601 }}$

Surprisingly, no responses from any significant HIV charities or service organisations were supplied by the Office for Disability Issues. Enquiries were made of the National AIDS Trust and Terrence Higgins Trust in order to obtain their response, if any, to the consultations. However, both organisations were unable to locate any such response on their computer hard drives and both organisations stated that a search of their paper archives would have been impractical. In an attempt to attempt to address this, a further Freedom of Information Act enquiry was made of the Office of Disability Issues in July 2012. This requested that the Office supply the consultation responses, if any, received from The National AIDS Trust, Terrence Higgins Trust, Positively Women, Oasis North London, Positive East and the UK Coalition of People Living With HIV and AIDS. These organisations were chosen as at the relevant time they were all active members of a UK wide campaigning 'umbrella' organisation called the UK Coalition. The Office for Disability Issues response is contained in Appendix 1. In essence, the Office responded:

In the questionnaire "Towards Inclusion - Civil Rights for Disabled People" there was only one question about people with HIV. In reply to this question: "Do you agree that HIV infection should count as a disability under the Disability Discrimination Act (DDA) from when it is diagnosed? (Para 3.11) the National Aids Trust answered "Yes" (sic). We have not been able to locate consultation responses from the other organisations that you have enquired about.

Following this somewhat disappointing response, a further Freedom of Information request was made in September 2012. In this request, I asked the Office to supply the consultation response received from The National AIDS Trust in its entirety. The response received indicated that:

The Department for Work and Pensions has carried out a thorough search of the filed responses for the information that you requested. We have not been able to locate the original consultation response document from the National Aids Trust. We do have an Excel spreadsheet record of the responses provided to the Consultation by the National Aids Trust and where these are recorded on that document, they are reproduced below. 
The full text of the Office's response is contained in Appendix 2 but, disappointingly, it yielded no additional information of relevance to the issues under consideration in this piece of work.

In conclusion, this section has demonstrated that the majority of respondents to the Government's consultation exercise were supportive of the proposal to deem HIV a disability from the point of diagnosis. Thus, of 207 responses received, 173 agreed that HIV should count as a disability from the point of diagnosis, 24 disagreed and 10 had no view either way. This section also demonstrated that a number of consultation responses displayed stigma towards PLHA based, in some cases, on the inaccurate belief that PLHA had inflicted themselves with the virus. ${ }^{602}$ This builds upon section 5.3 which demonstrated that part of the Government's and DRTF's decision to deem HIV a disability was due to an acknowledgment that PLHA were indeed subject to such stigma even when they experienced no symptoms associated with the virus. Attention will now turn to the legislation's passage through Parliament and analysis of the opinions of Parliamentarians regarding the decision to deem HIV a disability.

\subsection{THE LEGISLATIVE PROCESS}

Following consultation, a draft version of the Disability Discrimination Bill was published in December 2003 for pre-legislative scrutiny. ${ }^{603}$ It was considered by a Joint Committee of both Houses, who reported their findings on 27 May 2004. ${ }^{604}$ The Government published its response to the Joint Committee's report on 15 July $2004 .{ }^{605}$

The Bill originated in the House of Lords. ${ }^{606}$ It was introduced by Lord Grocott, the then Lords Chief Whip, and received its first reading in the Lords on $25^{\text {th }}$ November 2004. In the House of Commons, it received its first reading on $1^{\text {st }}$ March 2005. The Bill eventually received Royal Assent on the $7^{\text {th }}$ April 2005, thus becoming the Disability Discrimination Act 2005. ${ }^{607}$ A timetable fully outlining the progress of the Bill is attached in Appendix 3. Clause 18 of the Bill proposed to 'amend the definition of disability in respect of people with mental illnesses; deem people with HIV infection, multiple sclerosis, or cancer to be disabled for the purposes of the

G Herek and J Capitanio, ‘AIDS Sigma and Sexual Prejudice’ (1999) 42 (7). American Behavioural Scientist 1130 ; G Herek, 'AIDS and Stigma' (1999) 42 (7) American Behavioural Scientist 1106; Jane Northrop, 'A dirty little secret: stigma, shame and hepatitis C in the health setting' (2017) 43 Medical Humanities 218.

J Smookler, 'Making a Difference? The Effectiveness of Pre-Legislative Scrutiny' (2006) 59 (3) Parliamentary Affairs 522.

Joint Committee on the Draft Disability Discrimination Bill, Session 2004-5, HC 352, HL Paper 82.

The Government Response to the Report of the Joint Committee on the Disability Discrimination Bill,

Cm. 6276, 15 July 2004.

Disability Discrimination HL Bill (2004-05) [71]

LexisNexis UK, Halsbury's Is it in Force? (LexisNexis UK 2017) 
DDA; and clarify that there is no implied limitation to the scope of the regulation-making power which enables people to be deemed to be disabled' ${ }^{608}$

The Explanatory notes to the Bill further clarified that:

Clause 18(4) inserts a new paragraph 6A into Schedule 1 to the DDA. New paragraph 6A(1) deems people with HIV, cancer or MS to be disabled before they experience any of the effects described in section 1 of, or paragraph 8 of Schedule 1 to, the DDA

Whilst:

Clause 18(6) inserts a new paragraph 9 into Schedule 1 to the DDA to define HIV infection in recognition of the fact that there are two strains of the Human Immunodeficiency Virus recognised as capable of causing AIDS in human beings. ${ }^{609}$

Cancer, like HIV, was included within the definition of deemed disabilities as a result of the stigma attached to the illness even in the early stages of the illness i.e. before the cancer has a substantial adverse effect upon an individual's ability to undertake normal day to day activities. Indeed, the stigma faced by individuals with cancer was specifically mentioned during the Bill's second reading in the House of Commons. With regard to MS, it was originally thought that individuals with MS would be protected by the original definition of disability contained in the DDA 1995. However, the decision in Mowat-Brown v University of Surrey ${ }^{610}$ discussed earlier, illustrated the difficulties that the definition could present for individuals with MS and the decision was thus taken to deem individuals with MS as disabled from the point of diagnosis.

During the passage and consideration of the Bill, clause 18(4) received relatively little comment or scrutiny from Members of both Houses. However, comments made by a number of members illustrate quite clearly that the intention of the Government was to protect PLHA from the stigma attached to a diagnosis of HIV rather than the effects of the virus per se. The fact that the same was not proposed in relation to individuals living with cancer was the forum for heated debate. In the House of Lords Committee stage of the Bill, Lord Carter noted that 'as with MS and HIV, discrimination against a person diagnosed with cancer is often made on the basis of the diagnosis of cancer per se rather than the type of cancer and the unpredictability of the condition.....It is worth pointing out that the Under Secretary of State, Maria Eagle, in a letter to Roger Berry, said that: "People with cancer experience disability discrimination based on stigma from the point at which a diagnosis was made. Cancer is no different from HIV in this respect",611

ibid, para 13 xviii.

ibid, paras 184 and 186.

[2001] UKEAT 462_00_1012, [2002] IRLR 235.

HL Deb 20 January 2005, vol 668 col GC354. 
However, at the Report Stage of the House of Lords, Lord Tebbit was unmoved by this argument. He advanced a powerful argument against the clause, ${ }^{612}$ advocating that it should be taken out of the Bill. He stated:

As drafted, the clause would deem to be disabled certain categories of persons who have no disability; that is to say, it would say that black is white and white is black. It provides that a person who has cancer, an HIV infection or multiple sclerosis - and those three conditions only - is deemed to have a disability and hence to be a disabled person...

Let us take a particular case-a well-known one. Mr Chris Smith, the former Culture Secretary, told us last week that he was diagnosed as HIV positive 17 years ago. Happily, Mr Smith is well. He says that he suffers no symptoms, and he is clearly not disabled, and I hope that he will not be disabled by the infection which he has but which these days can frequently be maintained under control. But in law Mr Smith would be disabled if the Bill was enacted as drafted. I do not believe that he wants to be disabled; in the judgement of most of us, he is not disabled.

I understand that the reasoning — if that is not too strong a word — behind the paragraph is that a person with one of the three conditions that I mentioned will at some time in future become disabled. But I am more disabled than Mr Chris Smith, although I do not come within the scope of these provisions. My disabilities-impaired hearing and vision, failing memory, weakening muscles, which are familiar to most of us in this House - are all attributable to advancing age. ${ }^{613}$

From an analysis of the above passage it is readily apparent that in Lord Tebbit's opinion disability ought to be defined and assessed primarily by reference to the extent to which a physical or mental impairment affects an individual's ability to undertake normal day to day activities. This is an approach very much modelled on the medical model of disability and discussed in sections 3.2.5 and 4.2. Yet this ignores the social model of disability and the high levels of stigma experienced by PLHA. However, comments from other members of the Lords in response to Lord Tebbit illustrate that members of the House were aware of the stigma faced by PLHA. The most robust response to Lord Tebbit's argument came from Baroness Hollis. Baroness Hollis made explicit reference to the stigma experienced by PLHA and also referred to a number of contemporary external sources which documented such stigma. She stated: 
For HIV and some cancers we have evidence to show that disability discrimination starts early, at the presymptomatic stage. This discrimination is often reinforced by other prejudicial attitudes deriving from fear and ignorance but that does not make it any the less disability discrimination which the Act ought to deal with.

In particular, evidence in the form of research reports, newspaper articles, and so on, suggests that there is still widespread fear and prejudice against people with a diagnosis of HIV infection. The noble Lord, Lord Tebbit, mentioned the example of my right honourable friend Chris Smith. One can see from his history just how finely balanced a judgement some people must make when disclosing their HIV status. From his experience one can draw exactly the opposite conclusion from the one drawn by the noble Lord, Lord Tebbit; namely, that Chris Smith did not feel able to declare his HIV status even though, so far as he was concerned, he was well, able to climb the Munros with John Smith, and so on. However, he did not feel able to declare his HIV status because of the prejudice he considered he would then face. He and the Government considered that that prejudice should be protected against in the form of this Bill. As I say, I think you can read the Chris Smith experience in exactly the opposite direction from that suggested by the noble Lord, Lord Tebbit...

We have widespread support for the clause from the DRC, the Disability Charities Consortium, the Terrence Higgins Trust, the National AIDS Trust and the Multiple Sclerosis Society. We are dealing with those few conditions where there may be an impairment in the perception of the employer and others in advance of the obvious visibility of symptoms which would automatically bring someone within the protection of the DDA. We consider that in those exceptional cases we need this additional power. I hope that having heard the views expressed all round the House the noble Lord, Lord Tebbit, will accept that this is a decent, humane and proper way forward. I hope that he will withdraw the amendment. ${ }^{614}$

Confronted by widespread opposition Lord Tebbitt reluctantly withdrew his amendment to remove the clause from the Bill. At no other stage of the Bill's passage did the inclusion of HIV as a disability from the point of diagnosis provoke criticism and the Bill eventually received Royal Assent on $7^{\text {th }}$ April 2005. ${ }^{615}$

In conclusion, the decision to deem HIV as a disability from the point of diagnosis was largely supported by Parliamentarians. The only individual to disagree was Lord Tebbitt whose opinion of disability was very much formed by the medical model of disability. By holding this opinion 
of disability as being something assessed by reference to the extent to which a physical or mental impairment affects an individual's ability to undertake normal day to day activities, Lord Tebbitt ignored the social model of disability and the high levels of stigma experienced by PLHA. This was surprising because the decision to deem HIV a disability was an acknowledgement of the stigma that PLHA encounter in society and a factor specifically raised by the both the DRTF and the Government's response to the same. However, the decision to deem HIV a disability has been divisive; therefore, empirical research into the question of how PLHA perceive the concept of disability is a necessary part of this thesis. The conclusion to this chapter will now address the other areas which merit consideration as part of the empirical research of this thesis and outline the reasons why the UK has taken a different approach to protecting PLHA to that taken by both EU and international law.

\subsection{CONCLUSION}

This chapter illustrated the reasons why the UK has taken a different approach to protecting PLHA to that taken by both EU and international law. This was undertaken through analysis of the consultation exercise and parliamentary proceedings surrounding the passage of the relevant legislation which, in addition, will assist in formulating questions for the empirical study. The chapter also demonstrated that the decision to deem HIV a disability was heavily influenced by the stigma affecting PLHA which was a factor specifically mentioned by Parliamentarians during the legislation's passage.

The reasons why the UK took a different approach to protecting PLHA to that taken by EU and international law were twofold. Firstly, it was a response to the relatively restrictive interpretation of the definition of progressive conditions in paragraph 8(1) of Schedule 1 to the DDA 1995 as evidenced by the decision in Mowat-Brown v University of Surrey. ${ }^{616}$ This decision placed priority on an individual's personal prognosis rather than the likely typical effects of an impairment in order to determine whether it would have a substantial and adverse effect upon an individual claimant in the future. Many individual clinicians felt that providing such information about individual patients was 'an unpalatable type of speculation. ${ }^{617}$ As expert medical evidence was, and indeed still is, frequently required by courts and tribunals in order to determine whether an individual fell within the definition of 'disabled', claims involving

[2002] IRLR 235.

Emily Grabham, Brewing Legal Times: Things, Form, and the Enactment of Law (University of Toronto Press 2016) 114. 
progressive medical conditions were destined to fail due to the inherent uncertainty of being able to provide detailed expert prognoses for individuals. ${ }^{618}$

The decision to deem HIV a disability was, however, primarily an express acknowledgement of the stigma that PLHA encounter in society. ${ }^{619}$ Indeed, this was recognised by the House of Lords when debating the Bill's passage and represented an almost tacit use and acceptance of the social model of disability. ${ }^{620}$ The fact that stigma towards PLHA exists was, as Baroness Hollis rightly pointed out, evidenced by empirical data. ${ }^{621}$ This fact was also accepted by the majority of respondents to the Government's consultation exercise.

However, the decision to categorise HIV as a disability was, and indeed is, controversial both at the domestic and international level. ${ }^{622}$ One need only examine a number of responses to the Government's consultation exercise to uncover stigma and prejudice towards PLHA. Although these comments represent the view of the minority, they serve as a useful reminder as to why legislation to protect PLHA from stigma was required. They also serve to frame the themes and questions which merit consideration as part of the empirical research of this thesis. Thus, the issue of PLHA's reluctance to perceive of themselves as disabled emerged as a theme again during the course of this chapter. The issue of stigma towards PLHA also emerged as a recurrent theme. In recognition of this, in framing the semi-structured questions for the empirical research thought was given as to how stigma might interplay with a number of areas affecting PLHA within employment. Thus, questions were framed regarding an individual's decision to disclose, or not disclose, their HIV status. Questions were also formulated regarding individuals' experiences of HIV discrimination within employment, not only discriminatory acts experienced to date but also the fear of experiencing such acts in the future. Finally, questions were formulated regarding fears associated with job security because of HIV status and also attitudinal barriers impacting upon PLHA's ability to do their jobs. The full schedule of questions may be found in Appendix 6.

The next chapter will focus upon analysing the data obtained from participants taking part in the empirical research element of this thesis. It will focus on three primary areas. Firstly, attitudes of the general public to HIV/AIDS which necessarily involves consideration of the

Examples of the crucial role played by expert medical evidence can be seen in Abadeh v British Telecommunications plc [2001] IRLR 23 (EAT); Hospice of St Mary of Furness v Howard [2007] UKEAT 0646_06_1805, [2007] IRLR 944; Mahon v Accuread Ltd UKEAT/0081/08, [2008] All ER (D) 217.

See section 1.3 for discussion of stigma and PLHA.

See section 3.2.5 for discussion of the social model of disability.

Baroness Hollis referred to a report by the National AIDS Trust and Sigma Research at other points in her speech Dodds and others, 'Outsider Status: Stigma and discrimination experienced by Gay men and African people with HIV' (Sigma Research 2004).

A Broderick, The long and winding road to equality and inclusion for persons with disabilities: The United Nations Convention on the Rights of Persons with Disabilities (Intersentia 2015), 326. 
stigma affecting PLHA. Secondly, the career choices of those participants taking part in the empirical research and how they have been influenced by HIV. Thirdly, participants' experiences of employment including their experiences of disclosure and discrimination within employment. 


\section{CHAPTER 6: EMPIRICAL FINDINGS - SOCIOLOGICAL THEMES}

\subsection{INTRODUCTION}

This chapter analyses the empirical data obtained from the interviews with participants. As discussed previously in section 2.5 , the objective of the empirical research undertaken was to determine the experiences of People Living with HIV or with AIDS (PLHA) in relation to discrimination and the extent to which they feel adequately protected by the legal framework.

The themes examined by the empirical research were shaped by the initial review of non-legal sources undertaken in Chapter 1; the doctrinal research undertaken in Chapters 3 and 4; and the analysis in Chapter 6 of the reasons why the UK decided to deem HIV as a disability. Thus, the initial review of non-legal research detailed in Chapter 1 outlined that stigma and discrimination against PLHA continue to be matters of significant concern. ${ }^{623}$ This stigma prevents many

Simon Watney, Practices of freedom: Selected writings on HIV/AIDS (Duke University Press 1994); T Stoddard, 'Don't call it AIDS' New York Times (New York, 17 August 1994) 15; A Alonzo and N Reynolds, 'Stigma, HIV and AIDS: An exploration and elaboration of a stigma trajectory' (1995) 41 (3) Social Science \& Medicine 303; G

Herek and J Capitanio, 'AIDS Sigma and Sexual Prejudice' (1999) 42 (7). American Behavioural Scientist 1130; G Herek, 'AIDS and Stigma' (1999) 42 (7) American Behavioural Scientist 1106; Loretta M. Kopelman, 'If HIV/AIDS is Punishment, Who is Bad?' (2002) 27 (2) Journal of Medicine and Philosophy 231; G Herek, J Capitanio and K Widaman, 'HIV-related stigma and knowledge in the United States: prevalence and trends 1991-1999' (2002) 92 (3) American Journal of Public Health 371; R Parker and P Aggleton, P, 'HIV and AIDS-related stigma and discrimination: a conceptual framework and implications for action' (2003) 57 (1) Social Science \& Medicine 13;

$\mathrm{H}$ Liu and others, 'Relation of sexual risks and prevention practices with individuals' stigmatising beliefs towards HIV infected individuals: an exploratory study' (2005) 81 Sexually Transmitted Infections 511; P Boyce and others, 'Putting sexuality (back) into HIV/AIDS: Issues, theory and practice' (2007) 2 (1) Global Public Health 1; Moji Anderson and others, 'HIV/AIDS-related stigma and discrimination: Accounts of HIV-positive Caribbean people in the United Kingdom' (2008) 67 (5) Social Science \& Medicine 790; Anish P. Mahajan and others, 'Stigma in the HIV/AIDS epidemic: A review of the literature and recommendations for the way forward' (2008) 22 AIDS S67; P Hutchinson and R Dhairyawan, 'Shame, stigma, HIV: philosophical reflections' (2017) Medical Humanities 1; Joint United Nations Programme on HIV/AIDS, ‘Confronting discrimination' (UNAIDS 2017). 
PLHA from disclosing their HIV status, ${ }^{624}$ impacts upon their career choices and appears to affect members of minority communities in a disproportionate manner. ${ }^{625}$

Chapters 3 and 4 touched upon the role that law and policy play in combating discrimination and stigma against PLHA. Of key significance was the adoption of a definition of disability by the UN Convention on the Rights of Persons with Disabilities (CRPD) grounded in the social model of disability. The definition employed by the CRPD attempts to recognise and counteract the barriers faced by individuals with disabilities be they physical, environmental or attitudinal. By contrast, Chapter 5 identified that, at the domestic level, HIV is deemed to be a disability partly in order to combat stigma against PLHA and partly in order to overcome the restrictive interpretation of the legislative definition of progressive conditions taken by courts and tribunals. ${ }^{626}$

When considered from a purely normative perspective, the designation of PLHA as disabled by the EA 2010 goes beyond the UK's obligations in respect of PLHA as neither the United Nations Convention on the Rights of Persons with Disabilities or the Framework Directive provide automatic protection for PLHA on the grounds of disability. However, as demonstrated in chapter 4.3.1, the normative provisions of the EA 2010 are not being interpreted by the judiciary in a manner which complies with the social model of disability as the employ of an unfortunately outdated and stereotypical view of PLHA in the case of High Quality Lifestyles $v$ Watts illustrates. ${ }^{627}$

In light of this review of the relevant literature, a number of themes were identified as worthy of analysis. Semi-structured questions were then constructed around these themes. The themes were:

1. Public attitudes to HIV and PLHA; this theme was selected in order to ascertain participants' opinions and experiences of attitudes of the general public to HIV and PLHA. It was selected as a consequence of the identification of stereotypical attitudes 235; R Dray-Spira and others, 'Socioeconomic differences in the impact of HIV infection on workforce participation in France in the era of Highly Active Antiretroviral Therapy' (2007) 97 (3) American Journal of Public Health 552; S Degroote and others, 'HIV disclosure in the workplace' (2014) 69 (3) International Journal of Clinical and Laboratory Medicine 191; The People Living with HIV Stigma Survey UK, 'HIV in the UK: Changes and Challenges; Actions and Answers - The People Living With HIV Stigma Survey UK 2015 (The People Living with HIV Stigma Survey UK 2015 ) <http://www.stigmaindexuk.org/reports/2016/NationalReport.pdf> accessed 16 November 2017. bisexual men and black African men and women living with HIV in the UK' (National AIDS Trust 2009). 
persisting towards PLHA during the initial review of non-legal sources in chapter 1 and the review of the legislation's passage through Parliament in chapter 5.

2. Stigma; this theme was selected to gather participants' experiences of stigma directed towards themselves or others. It was selected as stigma was identified as a matter of key significance for PLHA during the initial review of non-legal sources in chapter 1, the doctrinal research in chapters 4 and 5 and the review of the legislation's passage through Parliament in chapter 5.

3. Discrimination; this theme was selected in order to collect participants' experiences of discrimination, assess their awareness of the EA 2010's provisions in relation to HIV and also ascertain their opinions on HIV being deemed a disability by the EA 2010. It was selected to assess whether the Act's designation of HIV as a disability, represents an adequate response to the issues faced by PLHA which is a key issue of this thesis.

4. Disclosure; this theme was selected to gather participants' experiences of disclosure of their HIV status in the workplace. It was selected as the doctrinal research identified in chapter 4.3.7 that PLHA are not adequately protected by the EA 2010 unless their employer has actual or constructive knowledge of their disability. This, in effect, places pressure on PLHA to disclose their status in order to gain the protection of the EA 2010. Disclosure also emerged as a matter of key concern for PLHA during the initial review of non-legal sources in chapter 1 .

A copy of the final interview schedule outlining the final semi-structure questions is attached in Appendix 6.

In this chapter, the data obtained from participants will be analysed thematically in three sections. Firstly, attitudes of the general public to HIV/AIDS which encompasses the theme of stigma. Secondly the overarching issue of the employment and career choices of participants which encompasses the themes of stigma and discrimination. Thirdly, participants' experiences within employment, which encompasses the themes of disclosure and discrimination. Where quotations from the research are used, a letter corresponding to the moniker ascribed to each participant in section 2.5 will be used. Chapter 7 will also analyse the empirical data but will concentrate upon the legal issues raised by participants, specifically the decision by the EA 2010 to deem PLHA as disabled. Concluding thoughts will be offered in Chapter 8 and in addition to thematically analysing the interview data, possible implications for the law and legal reform will be identified.

The chapter will demonstrate that there is an overarching narrative of stigma towards PLHA. It will also demonstrate that this stigma prevents PLHA from disclosing their status to their employers. Finally, it will demonstrate that the stigma attached to HIV was particularly acute for black African participants taking part in the empirical research suggesting that the domestic legal framework fails to adequately address the concept of multiple discrimination. 


\subsection{PUBLIC ATTITUDES TO HIV AND AIDS}

Public attitudes to HIV were a matter of significant concern to participants. It was felt that there was a lack of knowledge amongst the general public concerning matters relating to HIV. This led to stigmatisation of the condition and an increased fear of discrimination amongst the majority of PLHA. These matters will now be explored further.

\subsubsection{LACK OF KNOWLEDGE IN THE GENERAL PUBLIC}

A significant issue encountered by participants, not only in their employment but also in their day to day life was the lack of knowledge and awareness about the virus amongst the general public. Many described how the stigma surrounding HIV was rooted in now mistaken conceptions about the nature of the virus that had originated in the 1980s. Hence, often popular myths still persisted regarding the transmissibility of the virus:

The majority, vast majority of the population believe it's a death sentence....People don't understand how difficult it is to transmit... you can't contract the virus by shaking hands with somebody or sitting on a toilet seat after they've been there, or using the same knife and fork.

I, 40 year old, Heterosexual man who wasn't born in Africa

The first national health education campaign in response to the emergence of the virus in the 1980s used powerful imagery in order to highlight the severe and potentially fatal threat that the virus posed. In one advert a tombstone was shown along with the slogan, 'AIDS: Don't die of ignorance' ${ }^{628}$ This image was designed to follow the example set by earlier public health education exercises and arouse fear in the general public in order to dissuade individuals from engaging in particular behaviours. ${ }^{629}$ As Soames-Job notes, '[a] large number of health promotion campaigns are based on a simple strategy: get behind people with a big stick (lots of threat and fear) in the hope this will drive them in the desired direction. ${ }^{630}$

BFI, 'AIDS: Iceberg / Tombstone' (ScreenOnline) <http://www.screenonline.org.uk/film/id/1210462/index.html> accessed 27 November 2017. 
Yet this use of fear has the unintended consequence of increasing stigma against PLHA. ${ }^{631}$ This occurs due to members of the public deflecting the message and assuming it is not intended for them. Thus individuals whose fear has been aroused may project the message onto others who they feel are more likely to face the harmful consequences given their personal characteristics or behaviour. ${ }^{632}$ Individuals assume the message is not intended for them but for members of 'other' groups, e.g. MSM or black Africans, and so stigma is increased for those who populate these groups and PLHA as a whole. As S noted:

I think, people still just think back to, you know, the Eighties or the Nineties...I think people still put a moral attachment on it, you know, you're really promiscuous or you're a drug user or you're homosexual or whatever. Or, they think, you're going to get AIDS and die, or they think they could get it from you, because they don't know enough about it.

S, 33 year old, Heterosexual Woman not born in Africa

This lack of awareness was grounded in the fact that there was very little effort being made currently to educate society about HIV. Accurate, factual information available to the general public about HIV was felt to be either entirely lacking in certain areas or incorrect:

I do think that the body of information about HIV and AIDS is lacking. I say that not only from my experience here, but as a schools speaker...And so many times there is either no information, or the information is so outdated as to be quite scary.

Q, 53 year old, Man who has sex with other men

The implication of this is that younger members of society who were not witness to the public education campaign of the 1980s now have very little awareness about the virus. Correspondingly for those members of society who did live through the 1980s, their perception of the virus is based on outdated data and facts. The reality of HIV, and indeed living with HIV, is today much different. However, due to stigma, the difficulties faced by PLHA today are not medical but social in nature as I described:

I am a healthy person. [laughs] I'm not going to fall down dead. I take my medication, you know, I'm going to live a healthy life. I intend to live forever...And, I'm thinking, why do they keep putting these bloody barriers up? It's a disease that can affect anybody who is sexually active.

I, 40 year old, Heterosexual man who wasn't born in Africa 


\subsubsection{STIGMA}

In the course of the interviews with respondents it quickly became apparent that despite the effectiveness of current medication, stigma towards PLHA persists. One participant commented:

Because the reality of the medication now is...it works very well. It definitely keeps you healthy, and as I said, CD4 count rockets, viral load becomes undetectable. So effectively, it should be a non-issue, apart from taking tablets in the morning, tablets in the evening, which diabetics do, lots of other people do. But, you don't become unpopular because you're a diabetic; you become unpopular if you're positive.

C, 52 year old, Heterosexual man not born in Africa

By casually employing terminology like CD4 counts and viral loads, C's comments assume a certain level of knowledge from the listener. $\mathrm{C}$ is, in a way, unwittingly constructing a boundary by employing such terminology and distancing himself from individuals who are not members of the HIV community. This boundary serves to separate PLHA from those who are not and further exacerbates stigma towards PLHA. The stigma associated with HIV is exacerbated by fear, ignorance, anxiety, denial, shame, racism, xenophobia, and 'otherness'. ${ }^{633}$ This cooccurrence of multiple stigmatising characteristics is referred, by later work in this area, to as double stigma ${ }^{634}$ or layers of stigma. ${ }^{635}$

It is now advanced that the manifestation of stigma in relation to HIV/AIDS both varies according to time and place and is socially constructed. ${ }^{636}$ Accordingly, Petros and others found that the 'othering' of blame for HIV is central to social positioning, and is refracted through the

P Delius and C Glaser, 'Sex, Disease and Stigma in South Africa: Historical Perspectives' (2005) 4 (1) African Journal of AIDS Research 29; D Posel, 'Sex, Death and the Fate of the Nation: Reflections on the Politicisation of Sexuality in Post-apartheid South Africa' 200575 (1) Africa 125; I Niehaus, 'Death Before Dying: Understanding AIDS Stigma' (2007) 33 (4) Journal of Southern African Studies 845.

A Grossman, 'Gay men and HIV/AIDS: Understanding the double stigma' (1991) 2 (4) Journal of the Association of Nurses in AIDS Care 28; A Alonzo and N Reynolds, 'Stigma, HIV and AIDS: An exploration and elaboration of a stigma trajectory' (1995) 41 (3) Social Science \& Medicine 303; N C Ware, M A Wyatt and T Tugenberg, 'Social relationships, stigma and adherence to antiretroviral therapy for HIV/AIDS' (2006) 18 (8) AIDS Care 904. N Scheper-Hughes and M Lock, 'The message in the bottle: Illness and the micropolitics of resistance' (1991) 18 (4) Journal of Psychohistory, 409; G Herek, 'AIDS and Stigma' (1999) 42 (7) American Behavioural Scientist, 42(7) 1106; L Simbayi and others, 'Measuring AIDS stigmas in people living with HIV/AIDS: the Internalized AIDS-Related Stigma Scale' (2009) 21 (1) AIDS Care 27.

G Scambler and F Paoli, 'Health Work, Female Sex Workers and HIV/AIDS: Global and Local Dimensions of Stigma and Deviance as Barriers to Effective Interventions' (2008) 66 Social Science and Medicine 1848; L Gilbert, 'The mercurial piece of the puzzle': Understanding stigma and HIV/AIDS in South Africa' (2016) 13 (1) Journal of Social Aspects of HIV/AIDS, 8.
} 
multiple prisms of race, culture, homophobia and xenophobia. ${ }^{637}$ Sontag notes that within the popular imagination, injecting drug use, sex amongst MSM and/or promiscuity are associated with PLHA. ${ }^{638}$ Activities viewed by society as indulgent, deviant and sometimes delinquent. ${ }^{639}$ All of these issues were raised by participants. However, the issues were not raised in a discrete manner but overlapped with one another and, frequently, with other additional factors. Thus one participant raised the issue of the marginalised nature of PLHA in conjunction with the issues of the potentially infectious nature of the condition and its association with unacceptable practices:

\footnotetext{
You're being discriminated against for the association with drugs, sex, unpopular social groups, all the other good, good stuff that people get excited about...So all your unpopular things in society lead to the disease being unpopular. And the icing on the cake is, you can't cure it, and you can pass it on. So all those factors together is what makes it have such a stigma.

C, 52 year old, Heterosexual man not born in Africa
}

MSM were particularly self-aware that others might perceive them as being promiscuous and engaging in unsafe sexual encounters. In effect they were doubly disadvantaged due to not only of the association of HIV/AIDS association with unacceptable behaviour but also the mistaken perception amongst the wider population that MSM are by their very nature promiscuous:

That $[M]$ was, you know, having coke-fuelled orgies on a Saturday night with 200 men or something like that. Well I'm pretty sure that's where my mum's head goes every time. And I know that a lot of people hold that view, and I see that amongst my friends, and I have to challenge them.

M, 23 year old, Man who has sex with other men

Following on from the concept of promiscuity is the idea that through unacceptable practices and behaviours PLHA are responsible for their acquisition of the virus. ${ }^{640}$ Thus acquiring the virus by means of sex is 'thought to be more wilful and therefore deserves more blame. ${ }^{641}$ This idea is supported by interviews with individuals living with both cancer and HIV. In research 
undertaken by Dawson one interviewee commented, 'I've told everyone about [my cancer diagnosis] because you get sympathy for having cancer don't you....people just think you deserve to get HIV, like you're a guilty victim, whereas with cancer you're an innocent victim. ${ }^{\prime 642}$

Society's failure to accept that 'normal' individuals may also be HIV positive leads to society constructing HIV and AIDS as foreign concepts and, from a metaphorical perspective, as a societal invasion. ${ }^{643}$ This is not a new concept, Schiller, Crystal and Lewellen argue that there exists an ancient paradigm that attributes lethal, transmissible disease to groups seen as culturally different from the mainstream population. ${ }^{644} \mathrm{HIV}$ has followed this classic pattern of blame. Ever since the first cases of HIV were reported in the early 1980s, society viewed the virus as originating from 'outside'. ${ }^{645}$ Where 'outside' was varied dependent upon the cultural setting of the discussion in question. Initially, in places such as France and Germany, HIV was said to be imported by MSM from the United States of America. ${ }^{646}$ However, it was not long before HIV became to be perceived as emanating from peoples who were not only culturally different but also racially different. ${ }^{647}$ Schiller, Crystal and Lewellen argue that Western researchers soon began searching for descriptions of unusual African sexual practices, seeking to identify that the virus originated in remote populations. ${ }^{648}$ Although confusion still surrounds the origin of the virus Sontag notes that, illustrating the classic script previously taken by diseases such as syphilis, HIV is believed to have started in Africa, spread to Haiti, then the United States and then Europe. She argues:

Africans who detect racist stereotypes in much of the speculation about the geographical origin of AIDS are not wrong (Nor are they wrong in thinking that depictions of Africa as the cradle of AIDS must feed anti-African prejudices in Europe and Asia.) The subliminal connection made to notions about a primitive past and the many hypotheses that have been fielded about possible transmission from animals (a disease of green monkeys? African swine fever?) cannot help but activate a familiar set of stereotypes about animality, sexual license, and blacks. ${ }^{649}$

R Dawson, 'Coping with a dual diagnosis' (2007) 172 Aids Treatment Update 3.

D Crimp, AIDS: Cultural Anaylsis/Cultural Activism (MIT Press 1988) 3; Susan Sontag, AIDS and Its Metaphors (Penguin 1989); N Schiller, S Crystal and D Lewellen, 'Risky Business: The Cultural Construction of AIDS Risk Groups' (1994) 38(10) Social Science \& Medicine 1337; E Lieberman, Boundaries of Contagion: How Ethnic Politics Have Shaped Government Responses to AIDS (Princeton University Press 2009).

N Schiller, S Crystal and D Lewellen, 'Risky Business: The Cultural Construction of AIDS Risk Groups' (1994) 38(10) Social Science \& Medicine 1337.

ibid.

S Gilman, Disease and Representation: Images of Illness from Madness to AIDS (Cornell University Press 1998). N Schiller, S Crystal and D Lewellen, 'Risky Business: The Cultural Construction of AIDS Risk Groups' (1994) 38(10) Social Science \& Medicine 1337.

ibid.

Susan Sontag, AIDS and Its Metaphors (Penguin 1989) 52. 
This idea of certain marginalised racial or cultural groups being in some way responsible for HIV invariably leads to greater levels of stigma and discrimination against the members of such groups. Thus, African participants felt that being HIV positive merely contributed to and reinforced their position as outsiders in the UK. They also felt that certain sectors of the UK media portrayed immigrants as diseased, scrounging individuals with little of economic value to offer the UK. R noted:

[F]or the general public, HIV is something that happens way over there, you know. So, bringing it up close and personal, to a person that's probably only heard negative things about it, you don't want to embody yourself as [having] HIV and AIDS, you're diseased, you're filthy, you're about to die.

R, 38 year old, Heterosexual man born in Africa

Later in the interview the same participant commented:

Because as a black African man, you feel like an outsider... And when you have newspapers like the Sun for instance talking about these foreigners, these scroungers, health tourists and, carrying their diseases to the UK to benefit from the NHS, that does play on your mind.

R, 38 year old, Heterosexual man born in Africa

The stigma against black Africans is also exacerbated by the former colonial relationship between the UK and many African countries which plays a unique role in ascribing a disadvantageous identity to Africans within the UK. ${ }^{650}$

Mistaken perceptions of the nature of the virus itself also contributed to stigma for all PLHA. These were often firmly rooted in the now mistaken perception that the virus is inevitably fatal and were especially prevalent amongst older participants. Reference was made to the manner in which the virus was initially portrayed in the 1980 s with it being portrayed as an inevitably fatal condition:

It's the baggage, it's the stigma that's attached to it. Even within my own family, my wife is the only person who knows of my status. She will not let me tell anybody else... I mean we've talked at length, and the overriding picture that we both have in our minds is that television advert from the 1980s with the tombstone coming out of the ground saying, you know, “AIDS, Rest In Peace” you know. It's, you are going to die. 
Not only did participants experience stigma from others, they also frequently self-stigmatised and held negative perceptions of themselves:

And, when you come to the prejudice, I mean I am probably as prejudiced about HIV as anyone else; the difference is, I've got it, and it really affects how you rate yourself and see yourself, you know, your esteem and everything. Because, it was a bloody dumb thing to get.

C, 52 year old, Heterosexual man not born in Africa

From a legal perspective, the fact such high levels of stigma continue to persist against PLHA indicates that the UK is failing to meet its obligations under the CRPD. ${ }^{651}$ Article $8(1)$ of the CRPD provides that :

States Parties undertake to adopt immediate, effective and appropriate measures:

a) To raise awareness throughout society, including at the family level, regarding persons with disabilities, and to foster respect for the rights and dignity of persons with disabilities;

b) To combat stereotypes, prejudices and harmful practices relating to persons with disabilities, including those based on sex and age, in all areas of life;

c) To promote awareness of the capabilities and contributions of persons with disabilities.

Accordingly, there is a duty on States Parties to improve awareness regarding individuals with disabilities. Whilst there are some measures within the UK to reduce prejudice and negative attitudes towards individuals with disabilities, ${ }^{652}$ it appears such measures have little effect. ${ }^{653}$ Indeed, this matter was specifically raised by the UN Committee on the Rights of Persons with Disabilities in its inquiry into the UK under Article 6 of the Optional Protocol. It recommended

\footnotetext{
651 See section 3.2.5 for discussion of the CRPD.

652 For example s 149 (5) of the Equality Act 2010 places a duty on public bodies 'foster good relations between persons who share a relevant protected characteristic and persons who do not share it'. 
that the UK take, 'appropriate measures to combat any negative and discriminatory stereotypes or prejudice against persons with disabilities in public and the media. ${ }^{654}$

With regard specifically to PLHA it appears that little has been done to raise awareness or tackle negative stereotypes. As the UK has been lax in addressing stigma towards PLHA it has been left to HIV charities to fulfil this task. By way of example, the Terrence Higgins Trust runs the 'Positive Voices' community project where PLHA are employed as speakers to share their personal stories in a range of settings, including schools, colleges, faith-based groups and community organisations, with the aim of raising awareness of HIV and promoting responsible sexual health. ${ }^{655}$ With regard specifically to employment the Trust runs a 'Work Positive' programme which combines volunteer work experience, coaching, peer support and networking opportunities to support PLHA back to work. ${ }^{656}$

Stigma impacts significantly upon the lives of PLHA. ${ }^{657}$ Indeed, a study by Demi and others assessed suicidal tendencies amongst women living with HIV and discovered that of 214 women interviewed, $31 \%$ reported suicidal thoughts but no attempts, and $14 \%$ reported both thoughts and attempts. ${ }^{658}$ Whilst Croxford and others found that HIV positive men are twice as likely to commit suicide compared to men in the general population. ${ }^{659}$

\subsubsection{FEAR OF DISCRIMINATION}

The fear of possibly being discriminated against was a real concern for individuals who had not disclosed their HIV status to their employer. F wanted to work with children but feared the reactions of parents to her HIV status:

Well I think in the future, I'd quite like to go back to working with children, which does bring up a lot of questions in my mind, because you have to have quite a good

UN Committee on the Rights of Persons with Disabilities, Inquiry concerning the United Kingdom of Great Britain and Northern Ireland carried out by the Committee under article 6 of the Optional Protocol to the Convention, UN doc CRPD/C/15/R.2/Rev.1, Para. 114 (h)

Terence Higgins Trust, 'Positive Voices' (Terence Higgins Trust, 2017) <http://www.tht.org.uk/ourcharity/Resources/Community-projects/Positive-Voices> accessed 4 December 2017.

Terence Higgins Trust, 'Work Positive' (Terence Higgins Trust, 2017) <http://www.tht.org.uk/myhiv/Yourrights/Work/Work-Positive> accessed 4 December 2017.

See section 1.3 for discussion regarding stigmatisation of PLHA.

A Demi, 'Suicidal thoughts of women with HIV infection: Effect of stressors and moderating effects of family cohesion' (1998) 12 (3) Journal of Family Psychology 344.

S Croxford and others, 'Mortality and causes of death in people diagnosed with HIV in the era of highly active antiretroviral therapy compared with the general population: an analysis of a national observational cohort' (2017) 2 (1) Lancet Public Health e35. < http://www.thelancet.com/journals/lanpub/article/PIIS2468-2667(16)30020-2/fulltext> accessed 4 December 2017. 
relationship with the parents, whether I should tell them or not...And if you told them, would they really want to leave their children with someone who is HIV positive over someone who is not?

F, 32 year old, Heterosexual Woman not born in Africa

The fear of discrimination for some was so acute that one participant had failed to disclose their status to anyone at all:

My view is that if my status became known, I would be discriminated against by work if work knew. My neighbours if neighbours knew. My family if the family knew. My friends if my friends knew.

C, 52 year old, Heterosexual man not born in Africa

Others who had failed to disclose their HIV status to their employer or fellow employees had thought of cover stories in order to deal with potential enquiries from work colleagues about their health:

And, if anybody ever sees you taking tablets, they're always, "Oh, what are your tablets for?" "Oh, just antibiotics." And, you, you kind of brush it away, but there's always that question, you know, "Oh, are you ill then?" "Well no." "Why are you taking antibiotics then?" "Shut up and stop asking me questions." [laughs]

I, 40 year old, Heterosexual man who wasn't born in Africa

In complete contrast, those who had disclosed to their employers did not fear the possibility of being discriminated against:

I would dare somebody to discriminate me. I really, I would, I would welcome the opportunity to haul them over the coals.

$\mathrm{O}, 45$ year old, Man who has sex with other men

These individuals were primarily in professional occupations, they were also white. For black Africans, the situation could not have been more different. Black Africans overwhelmingly did not disclose due to the possibility of being discriminated against. For them not only was there the possibility of being discriminated against on the grounds of their HIV status, they also faced the possibility of being discriminated against because of their colour and/or nationality. In addition, as their colour and nationality were their more visible identities, they were loath to disclose and make their HIV 'visible'. This could subject them to another possible layer of discrimination. Comments made by L support this: 
I know it would be different for the white person to say, "I'm positive" the treatment will be different.

Question - You think it's harder for black HIV positive people [to disclose], as opposed to white HIV positive people?

Definitely. Definitely. Definitely.

Question - And what, there's just an extra layer of discrimination, you think?

Yeah, an extra layer of discrimination, exactly.

L, 49 year old, Heterosexual man born in Africa

\subsection{CAREER CHOICES}

Being diagnosed as HIV positive frequently prompted individuals to rethink their life and, in particular, their choice of career. Individuals often then went on to alter their employment. Such changes in career could be made for either positive or negative reasons. In the case of $\mathrm{C}$, the change in employment was for negative reasons - a desire for greater privacy and to avoid medical examinations connected with employment:

I moved from permanent employment into being self-employed. And the big advantage of that is that, you don't have a long-term commitment to the job. You're not under any obligation to create any social links or social networking within the job...The other advantage is that you never have to take a medical, because, what happens with a lot of senior jobs is, you end up having to go for a medical, and when you take a blood test they're going to find out.

C, 52 year old, Heterosexual man not born in Africa

A common theme was that PLHA often sought employment with companies that they thought would have good equality and diversity policies and be 'HIV friendly' in order to avoid the threat of discrimination. These organisations were, on the whole, organisations specifically targeted at PLHA or public sector organisations. There was also evidence of PLHA carefully thinking about their future career path and altering it. A significant number of participants had chosen to work for charities or service organisations that were targeted towards PLHA. Throughout the course of the interviews, three factors could be ascertained which explained this decision. The first was to avoid the prospect of being discriminated against on the grounds of HIV, thus when $\mathrm{S}$ was asked whether she worried about being discriminated against at work in the future, her response was as follows: 
Yeah, definitely. After Easter when I start work, I'm working for [a HIV service provider], and that kind of makes me go, oh lovely! [laughs] Because obviously that's going to be great. But yeah, I think if I was being employed somewhere else, I would worry about it, frankly.

S, 33 year old, Heterosexual Woman not born in Africa

The second reason was that some quite simply wanted to use their HIV as an asset. O described how he decided to apply for a job in the HIV sector after seeing positions advertised:

And, obviously, my HIV status at that point was, [laughs] was part of my CV in terms of the programme, you know, it was, it was, to my eyes, the best qualification that I had. And I liked that. That, all those sort of clichés, life gives you lemons, make lemonade;....my real area of expertise was living with HIV.

$\mathrm{O}, 45$ year old, Man who has sex with other men

Finally, there was a desire to help others in the same position:

It was, the difference was, is that I was doing something I was intensely passionate about, and that every day I would, I would be working with somebody that would be incredibly grateful for my experience, and for the fact that, they could identify with what I had been through, that they could understand that, and they could take hope that actually they were going to be $\mathrm{OK}$ after it.

O, 45 year old, Man who has sex with other men

It is important to note though that a key theme that emerged for many individuals was that HIV had limited their employment opportunities. HIV limited not only opportunities during employment but, in some instances, entire career paths. $\mathrm{O}$ had initially wanted to be an actor but re-evaluated his position after receiving his diagnosis:

The big concern for me while I was doing the drama course was, what do I do in terms of acting, how many out HIV positive actors are there?...What do I do about that? What should I do if I'm in a scene and I'm required to kiss somebody? I know there's no transmission risk, but what, what about, how would somebody feel, thinking that that's the case, and how would they deal with that?

$\mathrm{O}, 45$ year old, Man who has sex with other men

Having a career limited by HIV made an individual's diagnosis more difficult to deal with and led to feelings of anger. $\mathrm{U}$ had previously worked in a variety of international countries teaching English as a foreign language. She had started at the lowest rung of her profession and described the sacrifices she had made to succeed in her chosen field. Throughout the course of her 
interview it became apparent that she loved both her career and international travel. She was however forced to abandon both when she discovered that she had been diagnosed with HIV:

I've, you know, over the years I've kind of been through some really difficult periods when I've got very, very angry about having to sort of, abandon what I felt was the career that I loved. It's taken me a lot of adjusting...from a mental health point of view.

U, 46 year old, Heterosexual Woman not born in Africa

A common theme in relation to HIV affecting the employment opportunities of PLHA was the entry restrictions imposed by some countries upon PLHA. By way of example, D had firm plans to work in the United States. The employment he was planning to undertake required him to undertake additional study and an examination before he would be allowed entry into the profession in the United States. He learned of his diagnosis just after passing this examination:

But I had worked so hard for it, because I was planning to go to the US...So 2007, just after Christmas, which was when I got the devastating news...I knew that the US, you get a HIV positive result, that's it, you are not admissible to the United States.

D, 41 year old, Heterosexual man born in Africa

Whilst $\mathrm{T}$ discounted applying for a position in Singapore because of their entry restrictions:

A friend recommended a job to me in Singapore...I was very intrigued by the possibility, but Singapore doesn't allow people who are HIV positive in the country. [laughs] So, I wouldn't even apply for that job.

$\mathrm{T}, 50$ year old, Man who has sex with other men

\subsection{EXPERIENCES IN EMPLOYMENT}

Participants had varying experiences in relation to disclosure of their HIV status. A number had disclosed their status to their employers, whilst others viewed their status as an inherently private matter and chose not to disclose. In addition, some participants had experienced acts of discrimination whilst in employment. These matters will now be explored further.

\subsubsection{DISCLOSURE OF HIV STATUS}

In common with other individuals with hidden disabilities, disclosure presents a predicament for PLHA. By way of comparison, Engel and Munger undertook sixty interviews with two distinct groups of individuals with disabilities in order to ascertain the effect that the passage of 
the Americans with Disabilities Act 1990 had upon the everyday lives of its potential beneficiaries and the creation of a 'legal consciousness'. ${ }^{660}$ The two groups chosen by Engel and Munger were individuals with learning disabilities and individuals with physical disabilities which necessitated the use of a wheelchair. They noted that a dilemma existed for those individuals with learning disabilities due to the invisibility of their condition. Thus:

Many adults with learning disabilities prefer to conceal their condition, an option that is not available to those who use wheelchairs. Furthermore, the nature of the disability of an individual in a wheelchair is sharply focused and readily understood by most observers. Its significance is so obvious that it can be conveyed by a simple logo- the universal symbol for disability. By contrast, the nature and significance of learning disabilities are poorly understood, uncertain, and ambiguous in the eyes of the general public. ${ }^{661}$

In common with learning disabilities HIV is also poorly understood, uncertain, and ambiguous in the eyes of the general public and so for PLHA, the issue as to whether to disclose their status to their employer is often one of the most vexatious decisions they have to take during their employment relationship. The act of disclosure represents the passage of a Rubicon for that individual, their identity transformed from normality to disability. Their identity spoiled once their true self has been revealed. ${ }^{662}$

As previously discussed, 20 interviews were undertaken with PLHA within employment. Of the 20 participants interviewed $13(65 \%)$ had disclosed their HIV status to their employer and 6 $(30 \%)$ had not. In addition, $1(5 \%)$ individual had the option of disclosing taken away from him as his status was discovered during medical screening by his employer's occupational health department. These figures illustrate more individuals disclosing than the earlier study undertaken by Douglas. ${ }^{663}$ Douglas conducted research into the employment experiences of MSM and black African men and women living with HIV in the UK and discovered that $40 \%$ of relevant respondents had disclosed their HIV status to their supervisor or manager at work.

Of the 13 who had disclosed, 5 worked in the HIV sector and had effectively disclosed in order to reference their suitability for the job. Those participants who did disclose to their employer would rarely disclose immediately after diagnosis but only once they felt comfortable with their

D Engel and F Munger, Rights of Inclusion : Law and Identity in the Life Stories of Americans with Disabilities (University of Chicago Press 2010).

ibid 58.

Erving Goffman, Stigma notes on the management of spoiled identity (Penguin 1963).

N. Douglas, 'I just get on with it...A study of the employment experiences of gay and bisexual men and black African men and women living with HIV in the UK' (National AIDS Trust 2009). 
HIV status and their new identity. Indeed immediately following diagnosis individuals often opted not to disclose their status to anyone until they had come to terms with the issues surrounding their diagnosis:

In terms of disclosure, I, I didn't tell anybody at all for about six months...I wanted to get my own head around it first.

E, 46 year old, Man who has sex with other men

\subsubsection{FACTORS PREVENTING DISCLOSURE}

A number of factors were cited by participants who had not disclosed their status to their employers. Some did not want to complicate their working environment and were of the opinion that, in any event, their status was a personal and private matter:

I'm not disclosing because I want every day at work to be uncomplicated...I don't want to complicate my work by bringing in what I see as my personal, my personal life really.

F, 32 year old, Heterosexual Woman not born in Africa

The fear of individuals' responses and reactions to disclosure was also an issue. When F was asked what factors prevented her from disclosing, she responded:

I think it's just people's reactions really... And also, to me it seems unnecessary, for what you would have to go through to tell people.

F, 32 year old, Heterosexual Woman not born in Africa

Another theme to emerge was that participants assumed that disclosure would inevitably change their employer's perception of their identity. The concept of identity in relation to disabled people has aroused a great deal of interest in medical sociology. Shakespeare asserts that disability identity is important because it is through identity that an understanding of the complex relationship between individuals, society and biology emerge. ${ }^{664}$ Whilst Engel and Munger argue the link between identity and work is fundamental and in western culture, the very fact of being employed confers moral citizenship. ${ }^{665}$ Conversely, those who are unwilling or unable to work are viewed as individuals not entitled to the full respect due an adult citizen

T Shakespeare, 'Disability, identity and difference' in C Barnes and G Mercer (eds), Exploring the divide: illness and disability, (The Disability Press 1996)

D Engel and F Munger, Rights of Inclusion : Law and Identity in the Life Stories of Americans with Disabilities (University of Chicago Press 2010).
} 
and instead seen as marginal and dependent on others. ${ }^{666}$ Thus, a disability that limits or prevents employability also threatens social standing and self-respect. ${ }^{667}$ With these factors in mind it was of little surprise that a number of participants chose not to disclose their status, instead wishing to 'prove' themselves to their employers. $\mathrm{M}$ was relatively young and had only recently commenced employment. He was particularly anxious that his employers might perceive him to be incapable of doing his job or particularly prone to periods of ill-health and absence:

And I just wanted to ensure that I got into the job, showed that I could do my job and that, oh, if it's a year down the line and I disclose, that should be like, [he] hasn't had any sick days, [he] looks very healthy, [he] has worked, you know, does the job really well, maybe, he'll be fine in the job.

M, 23 year old, Man who has sex with other men

In a similar vein, A had previously disclosed his status to employers but opted not to disclose to his current employer. In his words, the major factor for not disclosing this time was:

[W]anting to prove myself as a non-disabled person.... wanting to show that I was as good as [a non-disabled person], and wanting to be judged and assessed in that way...I wanted to pull my weight, I wanted to prove I was as good as everybody else.

A, 45 year old, Heterosexual man not born in Africa

Society creates expectations about the characteristics of an employable adult. These include an acceptable physical appearance and social skills, basic motor skills, an ability to use common facilities, self-discipline and cognitive skills. ${ }^{668}$ These combine to form parameters as to who is and who is not employable. As individuals with disabilities have qualities that others (often mistakenly) perceive as falling outside of these parameters, it is clear that both $\mathrm{A}$ and $\mathrm{M}$ are hoping to illustrate to both their employer and fellow employees that they do, in fact, fall within the demarcated expectation of an acceptable, employable adult before revealing their HIV status.

The heightened level of stigma surrounding HIV also formed a barrier to disclosure, according with earlier work undertaken by Fesko. ${ }^{669}$ At its most extreme this prevented individuals from disclosing both within and outside the employment relationship. It also affected a number of

K Karst, Belonging to America: Equal Citizenship and the Constitution (Yale University Press 1989); J Handler and H Hasenfeld, The Moral Construction of Poverty: Welfare Reform in America (Sage Publications 1991).

D Engel and F Munger, Rights of Inclusion : Law and Identity in the Life Stories of Americans with Disabilities (University of Chicago Press 2010).

668 ibid.

669 S Fesko, 'Disclosure of HIV status in the workplace: considerations and strategies' (2001) 26 (4) Health \& Social Work 235 .
} 
participants' perception of self, causing them to view their HIV in a manner akin to Goffman's classic definition of stigma. To them HIV represented an 'attribute that is deeply discrediting' and that reduced them bearer 'from a whole and usual person to a tainted, discounted one. ${ }^{970}$ By way of example, $\mathrm{C}$ had never disclosed his status and, during the course of being interviewed, was asked whether he might he in the future:

Zero chance of that ever happening at all. I mean my neighbours don't know, my family don’t know, my friends don't know, work doesn't know...And there's a damn good reason is because it's the most unpopular disease in the world.

C, 52 year old, Heterosexual man not born in Africa

Membership of a particular ethnic group could also act as a barrier to disclosure. As discussed previously, Africans were particularly cautious and extremely reluctant to disclose to their employers. Four Africans took part in the research, all were black and of those, two were heterosexual man who had disclosed to their employer as they were both employed within the HIV sector and they thought it would be beneficial. One was a heterosexual man whose status was discovered by an employer during medical screening and thus had had the option of nondisclosure removed from him. The final African was a heterosexual woman who had not disclosed to her employer. Thus, no Africans had voluntarily disclosed to employers outside of the HIV sector. The 2 Africans who had disclosed expressed the view that they would not disclose for future positions if the employer was not an organisation working within the HIV sector. Therefore, when L was asked if he would disclose to an organisation outside the HIV sector, his response was:

My first answer will be, no, I wouldn't. And I do advise a lot of people as well, you know, don't say anything, just, go out and get a job and move on, you know.

L, 49 year old, Heterosexual man born in Africa

This accords with earlier research undertaken by Fesko and Douglas which discovered that HIV positive black Africans were concerned that disclosure of HIV added an extra layer of disadvantage to their visible identities as black people. ${ }^{671}$ Thus, as one respondent noted to Douglas:

\footnotetext{
670 Erving Goffman, Stigma notes on the management of spoiled identity (Penguin 1963) 3. 
Being from an ethnic background, being black, is one thing; to being from [an] ethnic background and can't communicate, that's another thing. Being from an ethnic minority and being black and having HIV, that's another problem. ${ }^{672}$

Fesko reviewed the workplace experiences and disclosure decisions of 18 PLHA. She discovered that 6 of the 18 participants were completely open about their HIV status within the workplace. 7 individuals had revealed their status to selected people in the workplace and at the point of doing so requested that the information be kept confidential. Finally, 5 individuals reported that they had not told anyone in their workplace. In common with Douglas, Fesko also discovered that HIV positive individuals described multiple levels of stigma associated with either their homosexual orientation or membership of an ethnic minority group.

\subsubsection{FACTORS ENABLING DISCLOSURE}

Unlike the earlier work of Fesko and Douglas this research discovered that, in general, MSM did not face significant barriers to disclosing their HIV status. ${ }^{673}$ However, one factor which might explain this was the fact that the MSM who participated were frequently employed in professional occupations which invariably have better policies and procedures in relation to equality and discrimination. Clearly individuals employed in a professional occupation will also have a greater degree of bargaining power in relation to their employment relationship rather than an individual employed in a manual occupation. By way of example, the MSM who participated in this study were, in general, highly educated and highly paid. Of the group of 9 , a third earned in excess of $£ 60,000$ per annum. The composition of salaries amongst the 9 MSM is illustrated below: men and women living with HIV in the UK' (National AIDS Trust 2009) 31. 


\section{Salary breakdown of MSM by \%}

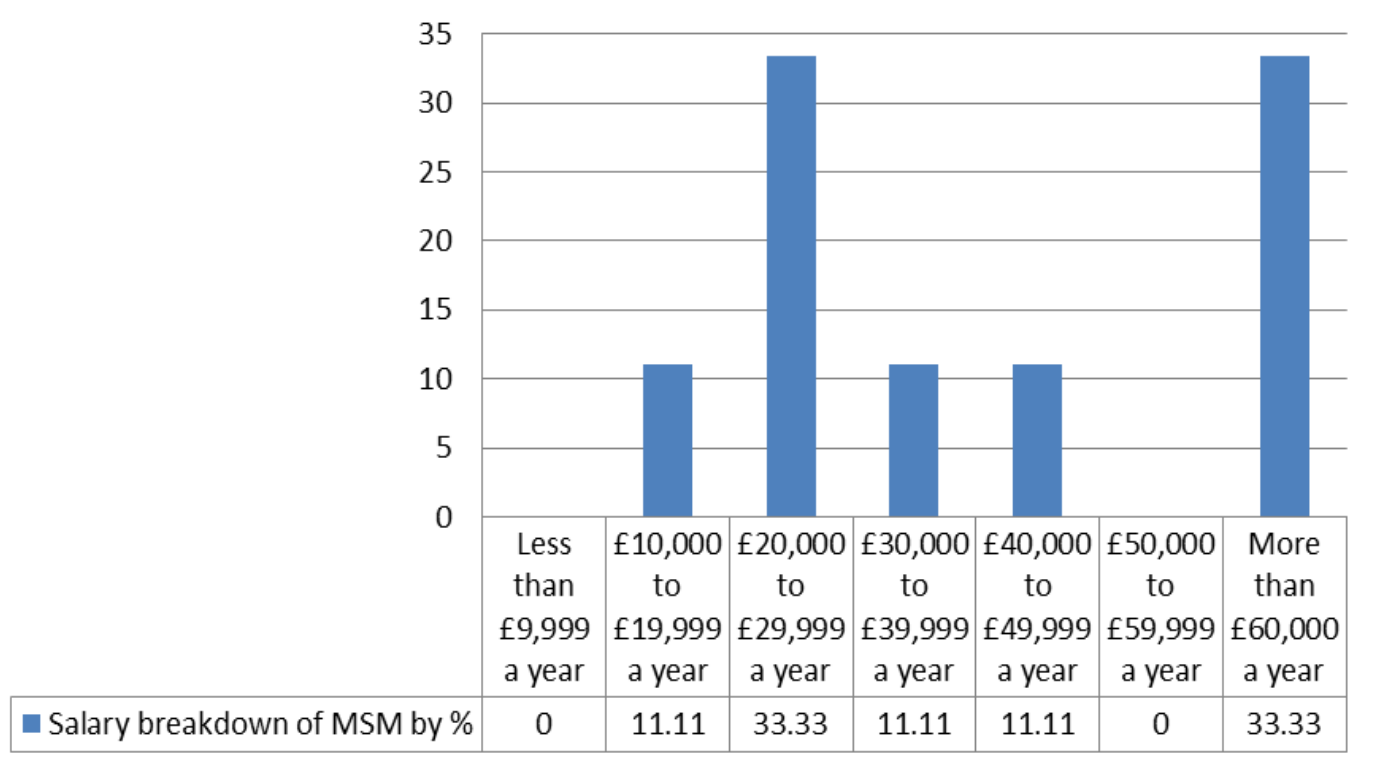

Only 1 of the group of 9 did not have degree level education and, in terms of job classification, 4 held professional occupations, 4 held managerial or technical occupations and the last classified his job as 'Other: Health Support'. This accords with research undertaken by DraySpira and others suggesting that HIV discrimination within employment operates in a socially differentiated manner and that individuals with higher education levels are less likely to experience discrimination. ${ }^{674}$ Thus, the fact that the possibility of discrimination is reduced makes disclosure amongst the members of this group more likely. However aside from this two specific factors were identified which assisted MSM in disclosing their HIV status. One was the significant strides that have been achieved in reducing stigma and discrimination around homosexuality in recent years. T stated he was more willing to disclose his HIV status as:

Maybe it's because I'm more hopeful generally...I'm fifty years old now, lots of things have happened in my lifetime that I didn't think I would ever see. Several, several of us historians of sexuality were involved in the US Supreme Court case where sodomy laws were overturned, and so homosexuality was essentially decriminalised. That is astonishingly recent, that is 2003. You know, it was like, 1967 in the UK. So, that makes, that in particular makes me quite hopeful.

$\mathrm{T}, 50$ year old, Man who has sex with other men 
The second factor was the fact that MSM had frequently already disclosed their sexuality to individuals and so were already versed in displaying previously hidden and potentially stigmatising identities. Some had felt liberated by the decision to previously disclose their sexuality and so repeated the decision in relation to their HIV status:

I mean I think, having already come out as a gay man, it's easier, you're almost practised in telling difficult news. So there are, there are elements to it which have made disclosure easier.

E, 46 year old, Man who has sex with other men

As discussed earlier, a common theme to emerge was that participants disclosed where they felt their HIV status was beneficial to the position they were applying for. Indeed this partly explains the $100 \%$ disclosure rate amongst Heterosexual Men born in Africa. Only 3 Heterosexual Men born in Africa participated in the research. 2 of these worked for HIV organisations and disclosed at the job interview stage, whilst the third had his status discovered when he underwent screening by Occupational Health at his place of employment.

A key event which often prompted disclosure was when a participant suffered a period of ill health. Ill health was not so much an enabling factor to disclosure but rather an event which often forced individuals to disclose. When faced with a prolonged period of ill health individuals disclosed, sometimes to gain the protection of the EA 2010, but often just to explain that their reduced work capability was due to factors beyond their control:

I was having problems, feeling tired, and so...I'd be falling asleep. So I got into the habit of, of literally getting... under the desk and have a little half an hour nap [laughs] some days. And then I thought, you know, I need to just talk to my boss about this. O, 45 year old, Man who has sex with other men

When I returned to work,...I was still clinically diagnosed with having AIDS... so there was a high probability I could have wound up back in hospital... but I was so bored sitting at home, I wanted to get back to work. So, I wanted somebody who, if the worst case happened and I did wind up back in hospital, I wanted somebody who could, you know, say to HR, 'Look, [laughs] this guy is really ill. Leave him alone.'

I, 40 year old, Heterosexual man who wasn't born in Africa

\subsubsection{BENEFITS OF DISCLOSURE}

Disclosure offers individuals legal protection. As Fitzgerald notes, failing to disclose their disabilities means that adjustments will not be made for individuals with hidden disabilities 
which allow them to more easily engage with society ${ }^{675}$ Disclosure also made participants feel safer at work:

I mean I feel a lot more safe now...I can tell that the manager is also more, $\mathrm{mm}$, in some ways more attentive...And I feel totally safe.

P, 43 year old, Man who has sex with other men

Thus when participants were asked whether they had made the correct decision in disclosing their HIV status, they responded as follows:

Yes. I absolutely think it is. Since I stood up and spoke publicly, I've had about, I think five officers who have approached me confidentially, because my name's on our intranet site as being somebody who knows something about HIV and AIDS. Five people have approached me, two have been diagnosed, and the other ones, because somebody close to them has been diagnosed, seeking support, information, signposting.

Q, 53 year old, Man who has sex with other men

Those participants who had disclosed also described the benefits of having disclosed their condition to their employer. A number remarked that it was easier to manage their health and HIV following disclosure. Some PLHA have to take medications at regular prescribed intervals throughout the day and so disclosure made the process of adhering to their treatment regimen much easier:

It's simple things like, if I had to take tablets in the middle of the day, it was much easier if I could just take them and I could say what they were. And also at the time with the big emphasis on adherence, it felt easier to walk out in the middle of a meeting, or, just in the middle of a meeting, to take tablets and say, 'I have to take them now,' and people couldn't complain about it. So that was quite useful.

A, 45 year old, Heterosexual man not born in Africa

Although highly effective, HIV medication is notorious for its side effects. A number of participants responded that one of the benefits of disclosure was that it made it much easier to manage these side effects and provided assurance to them in the fact that their employer would be aware of the reason for their possible underperformance at work: 
It's easier to be able to say to people, 'Look, I'm not feeling good today.'...I don't want to lie, why should I lie? I'm too old to [laughs] lie about it.

Q, 53 year old, Man who has sex with other men

\subsubsection{DISADVANTAGES OF DISCLOSURE}

A great deal of the literature in Disability Studies addresses the complexities of disclosure associated with hidden disabilities. ${ }^{676}$ The term hidden disability may be employed in a number of ways. ${ }^{677}$ It may mean those disabilities which are not easily seen, measured or objectified. The corollary of this is that such disabilities, like HIV, can be kept hidden, thus 'people with hidden disabilities can choose whether or not to keep them hidden, they can manage their illness identities. ${ }^{678}$ Yet, choosing to keep the disability hidden may present a number of difficulties. These include the risk of being given a label that could be less acceptable than the one associated with their condition and not being given the kind of accommodations and adjustments that could be made in order that they might function at an optimal level. ${ }^{679}$

Another disadvantage of disclosure is that PLHA lose the ability to manage their identities. Thus, PLHA often actively choose to manage their identities, they choose when and to whom to disclose. Some PLHA feel that the longer they can keep their condition hidden the better, others are completely open, while most engage in selective disclosure which involves telling only family, close friends and those who need to know. Indeed, in common with hidden disabilities, those PLHA who choose not to disclose their condition often engage in various types of behaviour to hide their condition. Fitzgerald notes that these actions range from developing alternative explanations for their behaviour to avoiding interactions where they might have to disclose. ${ }^{680}$

Alternatively, some employees may hesitate to disclose their status, not because they fear dismissal, but because they anticipate more subtle discriminatory reprisals, for example assignment to diminished responsibilities or the fear of being ostracised by co-workers. ${ }^{681}$ The

For discussion of this see M Sherry, 'Overlaps and contradictions between queer theory and disability studies' (2004) 19 (7) Disability \& Society 769.

M Fitzgerald, "'You look so well” The Multiple Facets of Hidden Disabilities' (2000) 20 (3) Disability Studies Quarterly 254.

M Fitzgerald and K Paterson, 'The hidden disability dilemma for the preservation of self' (1995) 2 (1) Journal of Occupational Science, 13, 15.

M Fitzgerald, "'You look so well" The Multiple Facets of Hidden Disabilities' (2000) 20 (3) Disability Studies Quarterly 254.

ibid.

A Leonard, 'Employment discrimination against persons with AIDS' (1985) 10 (3) University of Dayton Law Review 681. 
issue of discrimination will be discussed separately below but one individual who did report an extremely negative experience following her decision to disclose was S. She worked within a primary school and disclosed to her employer six months after her diagnosis. They were initially supportive but their attitude changed when she decided to volunteer, in her own time, as a positive speaker for an HIV organisation. She described the process as follows:

Well, they, they basically said, 'Oh, either you work here and you don't do that, or you do that and you leave.' So, kind of like, all very nice, you know, and smiley, but essentially that was what they said. So, so I left. So, yeah.

Question - And how did that make you feel, what they had said?

...It was sad really, because, because, it's because they were all just so sort of nice, you know, I couldn't turn round and say, 'Oh they fired me,' or they, you know, were really discriminative against me because it was all done so nicely.

S, 33 year old, Heterosexual Woman not born in Africa

S's narrative demonstrates that even though she had clearly been discriminated against by the school, in her mind it was her decision to leave. This is not uncommon as Douglas found that PLHA often found it difficult to specifically define discrimination as HIV-related since the perpetrators would act in ways that would avoid them being called to account for their actions. ${ }^{62}$ Thus, the School employed somewhat subtle forms of exclusion and unequal treatment that contributed to $\mathrm{S}$ believing that her treatment was not discriminatory.

Although this was a particularly bad experience, others reported poor management by an employer or confusion regarding how to proceed with an individual following disclosure:

They didn't seem to have a clue, when the issue arose with HR...My CD4 just crashed...to a dangerous level and my consultant said, 'What's going on? You perhaps need to readjust your hours and your working patterns if you like. Go and have a discussion with them.' So when I approached them, they didn't seem to know how to go about it, what the procedure was. They seemed to know that they had to contact my doctor and I had to give them permission, which I did. They then wrote to my doctor, and the letter...doesn't mention anything about reasonable adjustments, disability. It actually reads like they were questioning my ability to do the job at all. U, 46 year old, Heterosexual Woman not born in Africa 
Similarly:

I don't know what $[\mathrm{X}]$ is like now but at that time it was a very officious organisation, everything ran on paperwork and box-ticking and those sorts of things. And if you didn't fit in exactly to the boxes that you had to tick, then they always had a problem with you.

J, 42 year old, Man who has sex with other men

But the overwhelming theme was that those participants who opted to disclose, found the process beneficial. This accords with Douglas's work concerning the disclosure experiences of MSM, where for over three-quarters of the men the response to the disclosure of their HIV status was generally positive, with less than one in ten reporting a negative response. ${ }^{683}$

\subsubsection{EXPERIENCES OF DISCRIMINATION}

As detailed above black Africans expressed clear concerns about being subjected to discrimination on more than one ground, yet when considering actual acts of discrimination, it was clear that other groups were also vulnerable to discrimination because of their already stigmatised status. P was a MSM who had not disclosed his HIV status to his employer or fellow employees; however, he was fully open about his sexuality. P described one particularly distressing incident involving a fellow employee with whom he had previously had a difficult working relationship:

So we got into conflict again...Little did I know that she would react so badly, because she turned around in front of everyone... At the time I had a cyst on my neck which was quite big. So she turned around in front of everyone, she said, 'Oh look at your neck. I think you've got AIDS. You don't belong here, you should be put behind bars.' And, so that left me quite shaken [laughs] for a few seconds to say the least. P, 43 year old, Man who has sex with other men

At the time $\mathrm{P}$ had not disclosed his HIV, so but for his sexual identity, he would not have been subject to these comments from his work colleague. He was subjected to these comments because of the intrinsic association between HIV/AIDS and MSM. ${ }^{684}$

ibid.

A Petro, After the Wrath of God: AIDS, Sexuality, and American Religion (Oxford University Press 2015). 
Instances of overt discrimination were, thankfully, rare. Much more prevalent than overt discrimination were instances of individuals being subjected to subtle, covert discrimination. This was a common theme and there were many instances. Q wanted to raise awareness of HIV and thus make his HIV more 'visible'. For Q his intention was to raise awareness of HIV within his workplace. Q described what resulted from his decision evidencing a culture of stigma and discrimination within his organisation which led him to fear for his personal safety:

I have tried to introduce a programme of education on HIV and AIDS. So, for World AIDS Day for several years I organised lunchtime briefing sessions bringing speakers in, usually from Terrence Higgins because I do quite a lot of work with them. I've given up, because on a number of occasions I've put posters up around the building... Posters have been defaced, some one time were slashed with a knife, or removed. Q, 53 year old, Man who has sex with other men

Q's employer also illustrated the culture of discrimination evident within his organisation by the manner in which Q was treated immediately following disclosure of his HIV status:

[B] efore I came back to work, a week before, I came into see my line manager and told her it wasn't just viral encephalitis, it was HIV and I had AIDS as well. And she asked me not to tell the team I managed because she was concerned about how they would react to it.

Q, 53 year old, Man who has sex with other men

Black Africans were particularly affected by issues of subtle, covert discrimination. K described how she quickly learnt not to explicitly state that she was HIV positive on an application form:

Question - Roughly, do you know how many jobs you would have applied for and put on you were HIV positive? 10 to 15 ?

Yes, 10 to 15 .

Question - And it was just always no, sometimes never a response at all?

Yes, no response.

Question - But they'd never say it was because you were HIV?

No.

K, 48 year old, Heterosexual Woman who was born in Africa 
A number of the participants worked for HIV organisations and had often heard first-hand accounts from PLHA who had been the subject of discrimination at work:

I've had to support lots of people who have been discriminated so my work as a patient rep, as a health trainer and now...doing all of the communications that I do within [a HIV charity]. So, the website and the forums where we talk there's lots of discussions about people trying to deal with getting reasonable adjustments in the workplace or where as soon as they do that, suddenly they find themselves side-lined and out of a job at the end of day. And so, it happens a lot, and I, I see it, I see it happening, I hear about it.

O, 45 year old, Man who has sex with other men

Similarly:

I have come cross situations where people have said it's become common knowledge that they are positive, and there has been blatant discrimination or cases where people, it's come out and all of a sudden they feel that every time they go into a kitchen someone's going in to wash after them, you know, that sort of thing. So, they're not using the same cups and that sort of stuff. Again, is it entirely accurate? I don't know. I can't say. But we do definitely hear these kinds of stories.

R, 38 year old, Heterosexual man born in Africa

\subsection{CONCLUSION}

Instances of overt discrimination towards PLHA who had disclosed were rare. Instead, discrimination manifested itself in more subtle means as illustrated by the countless rejections from companies that K experienced when she disclosed her HIV status on job application forms.

It was also apparent from the responses received from participants that public attitudes towards HIV were a matter of grave concern. It became evident that many members of the general public rely on outdated medical information to construct notions of the risks surrounding the transmissibility of HIV. The interpretation of this outdated and inaccurate information results in continued stigma towards PLHA which unfortunately is still associated with unacceptable sexual or social practices. ${ }^{685} \mathrm{HIV}$ is perceived to be a 'bad' illness associated with immorality, 
in contrast to 'good' illnesses which individuals are often much happier to share details of their diagnosis as illustrated by the work of Dawson. ${ }^{686}$ Thus, there is an element of moral judgement by society of PLHA with their diagnosis being perceived as a sign of immorality. ${ }^{687}$

Due to the invisibility of the condition, disclosure presents a predicament for PLHA. Indeed, the research identified a number of factors which prevented participants from disclosing their HIV status to their employers. One factor was that some participants considered their HIV status to be an inherently personal matter and did not want to complicate their working environment. Another factor which prevented disclosure was a desire to avoid a change in how they were perceived within the workplace. This was coupled with a worry that a changed perception of their abilities post disclosure would mean that they would inevitably be perceived as falling outside societal parameters of who is considered an employable adult. ${ }^{688}$

Significantly, the heightened level of stigma surrounding HIV also formed a barrier to disclosure. Thus, as $\mathrm{C}$ stated when questioned about the possibility of disclosing his status in the future, his response was, 'Zero chance of that ever happening at all.' There was also a clear difference in the manner of the disclosure experiences of MSM and black Africans. A number of MSM in this survey had well paid, professional occupations which gave them greater bargaining power in their employment relationships and made them feel more comfortable about disclosing. By contrast, black Africans were much more cautious about disclosing, were employed in less well remunerated positions and none had voluntarily disclosed their status to their employer. This not only suggests HIV discrimination and stigmatisation within employment operates in a socially differentiated manner ${ }^{689}$ but also that race, culture, homophobia and xenophobia all contribute to layers of stigma towards PLHA. ${ }^{690}$ With this in mind, the Government's failure to bring into force section 14 of the EA 2010, dealing with multiple discrimination, is unfortunate ${ }^{691}$ Not only does the failure to bring into force section 14 mean that the EA 2010 is not fully compliant with the United Nations CRPD, it also represents a missed opportunity to tackle more effectively the heightened level of stigma and discrimination directed towards PLHA. ${ }^{692}$ With the above in mind, it might be thought that

(2008) 67 (5) Social Science \& Medicine 790; P Hutchinson and R Dhairyawan, 'Shame, stigma, HIV: philosophical reflections’ (2017) Medical Humanities 1.

R Dawson, 'Coping with a dual diagnosis' (2007) 172 Aids Treatment Update 3.

P Keogh and others, 'Morality, responsibility and risk' (Sigma Research 2006); A Petro, After the Wrath of God: AIDS, Sexuality, and American Religion (Oxford University Press 2015).

D Engel and F Munger, Rights of Inclusion : Law and Identity in the Life Stories of Americans with Disabilities (University of Chicago Press 2010).

R Dray-Spira and others, 'Socioeconomic differences in the impact of HIV infection on workforce participation in France in the era of Highly Active Antiretroviral Therapy’ (2007) 97 (3) American Journal of Public Health 552.

G Petros and others, 'HIV/AIDS and 'Othering' in South Africa: The Blame Goes On!' (2006) 8 (1) Culture,

Health \& Sexuality 67.

HM Treasury, 'The Plan for Growth’ (HM Treasury 2011), 23.

See section 4.3.3 for discussion of section 14 of the EA 2010. 
PLHA would welcome the decision by the EA 2010 to automatically deem them to be disabled from the point of diagnosis, yet as shall be seen in Chapter 7, the decision has not been universally popular. It is to this matter, and the legal protections afforded by the EA 2010, that this work will now turn. 


\section{CHAPTER 7: EMPIRICAL FINDINGS - LEGAL THEMES}

\subsection{INTRODUCTION}

This chapter will analyse the empirical data obtained from the interviews with participants. It will focus primarily on whether the Equality Act 2010 (EA 2010), and the Act's designation of HIV as a disability, represents an adequate response to the common societal issues faced by People Living with HIV or with AIDS (PLHA) and is consistent with international and European legal obligations.

As discussed in section 6.1, the themes examined by the empirical research were shaped by the initial review of non-legal sources undertaken in Chapter 1 and the doctrinal research undertaken in Chapters 3 and 4. The doctrinal research undertaken in chapters 3 and 4 touched upon the role that law plays in combating discrimination and stigma against PLHA. At the domestic level, PLHA are protected from discrimination by the concepts of direct discrimination, ${ }^{693}$ indirect discrimination, ${ }^{694}$ victimisation ${ }^{695}$ and harassment. ${ }^{696}$ There is also a duty placed upon employers to make reasonable adjustments ${ }^{697}$ and a failure to make a reasonable adjustment amounts to an act of discrimination. ${ }^{698}$ There is also provision for multiple discrimination to be prohibited, though the relevant section of the EA 2010 has not been brought into force ${ }^{699}$ As previously explained in chapter 6.1, in light of this review, semistructured questions were constructed around the following themes:

1. Attitudes of the general public to HIV and PLHA

2. Stigma

3. Discrimination

4. Disclosure.

In this chapter, the data obtained from participants will be analysed thematically in four sections. Firstly, the general awareness of participants of the EA 2010 and its protection of PLHA. Secondly, the awareness and experiences of PLHA in relation to reasonable adjustments under the EA 2010 will be analysed. This encompasses the themes of disclosure and stigma as in order

Section 13 Equality Act 2010

Section 19 Equality Act 2010.

Section 27 Equality Act 2010.

Section 26 Equality Act 2010.

Section 20 Equality Act 2010.

Section 21 Equality Act 2010.

Section 14 Equality Act 2010. 
to have reasonable adjustments made PLHA must disclose their status, which many are reluctant to do as a consequence of the stigma surrounding the virus. Thirdly, the thoughts and opinions of participants regarding PLHA being protected from discrimination which encompasses the themes of discrimination and stigma. Finally, the attitudes of participants to HIV being automatically classified as a disability by the EA 2010 which encompasses the themes of stigma and the attitudes of the general public in relation to HIV and PLHA. As in chapter 6, where quotations from the research are included, a letter corresponding to the moniker ascribed to each participant in section 2.5 will be used.

The chapter will demonstrate that a number of the PLHA interviewed objected to being classified as disabled by the EA 2010 and viewed disability as a concept to be constructed very much along the lines of the medical model. ${ }^{700}$ It will also demonstrate that PLHA within employment are currently discouraged from requesting reasonable adjustments under the EA 2010 due to a number of factors. In light of these findings, the chapter concludes that the current manner in which the EA 2010 protects PLHA requires amendment.

\subsection{AWARENESS OF THE LEGAL FRAMEWORK}

In terms of legal protection for PLHA, all participants were aware that PLHA were protected from discrimination and this was overwhelmingly welcomed. However, awareness of the fact that PLHA are classified as disabled for the purposes of the EA 2010 was significantly less pronounced. Therefore when participants were asked if they were aware that PLHA were protected on that basis, responses received included:

No.

D, 41 year old, Heterosexual man born in Africa

Partially aware of that. Not completely aware of that.

J, 42 year old, Man who has sex with other men

I didn't know in what format [I was protected] but I knew that I would have a leg to stand on if if I lost my job due to having HIV.

F, 32 year old, Heterosexual Woman not born in Africa

The protection afforded to PLHA by the EA 2010 was perceived by many as a factor which enabled and supported their decision to disclose or one which might enable them to disclose at 
some point in the future. A had not disclosed to his current employer and when the protection afforded by the EA 2010 was described he stated:

That does make me feel more confident about disclosing.

A, 45 year old, Heterosexual man not born in Africa

However even with the protection afforded to PLHA by the EA 2010, a small but significant minority of individuals would not disclose their HIV status to their employer. ${ }^{701}$ This is both understandable and unfortunate as individuals are unable to gain the full benefit and protection of the EA 2010 unless they are prepared to do so. By way of example, an employer is under no duty to make reasonable adjustments for an employee with a disability unless the employer knows or could reasonably be expected to know that the employee has a disability. ${ }^{702}$

Participants who opted not to disclose drew a clear distinction between their working and private lives. They considered that their medical history was personal to them and that the issue of their, or indeed anyone else's, medical condition was completely irrelevant to their work. References were made to the fact that they also did not want to have knowledge of any health conditions fellow employees might have:

Question - And, taking into account the protection that the Equality Act gives people who are HIV positive...you wouldn't feel more comfortable about disclosing your status?

Oh zero. I mean, people don't forget it...And, I mean, [laughs] very bizarre thing, why on earth would they need to know?...So it's really, why does an employer need to know any of my medical history anyway?

C, 52 year old, Heterosexual man not born in Africa

In common with Douglas it was observed that even with the legal protection afforded by the EA 2010, it was common for participants to undertake a very careful type of cost-benefit analysis as to whether to disclose their HIV status: ${ }^{703}$

It's all about risk, balancing the risk isn't it, as far as I'm concerned, and it's a risk I just don't want to take. I might be doing them a disservice, they might be perfectly honest and, and, you know, it might be no problem at all; I just wouldn't want to take the risk.

See section 6.4.1 for the data regarding disclosure of participants to their employers.

Sch 8, para 20 EA 2010.

N. Douglas, 'I just get on with it...A study of the employment experiences of gay and bisexual men and black African men and women living with HIV in the UK' (National AIDS Trust 2009). 
PLHA who opted not to disclose their status to their employer recognised that they were faced with a quandary. They could continue not to disclose to their employer and so remain unable to access the full protection of the EA 2010 or they could opt to disclose and relinquish control of information that many would rather remain private. As $U$ described:

So you are forcing people into, into choices... Don't disclose and therefore not be able to exercise your rights at all if you run into trouble, or disclose...And the idea is, if you disclose at the application stage employers are not allowed to discriminate against you at that point, but who's to say they won't? It's very difficult to prove at that stage, almost impossible to prove.

U, 46 year old, Heterosexual Woman not born in Africa

Indeed the legislation relating to this area merely served to confuse some participants. As Dodds and others note:

The provision of equal opportunities monitoring mechanisms are meant to provide protective structures for individuals if discrimination arises. However, some suspiciously regard these systems as a means of imposing a duty to disclose HIV status hidden under a rubric of increased rights..$^{705}$

The result is that many PLHA do not believe that they will not be discriminated against by their employer if they choose to disclose:

Because the only time I've come across it is in terms of that application form... And in a way it kind of makes you feel vulnerable, it doesn't make you feel protected at all, it makes you feel like I'm going to have to say and if I say then I'm at a disadvantage.

S, 33 year old, Heterosexual Woman not born in Africa

It was, however, undeniably apparent that the EA 2010 made some individuals more confident about disclosing and bringing a claim to an Employment Tribunal if required. U worked for an organisation which provided services to PLHA and had disclosed to them when applying for her job in order to illustrate her suitability for the particular role she was applying for. The protection afforded to PLHA by the EA 2010 made her feel more comfortable about disclosing to private sector employers in the future because: 
Probably erroneously that there's some kind of legal redress if you then feel that they don't behave according to the law... you can threaten them with legal action.... Whether you can actually, you know, realistically achieve that is another matter. [laughs]

U, 46 year old, Heterosexual Woman not born in Africa

Both individuals who had disclosed to their employer and those who had not were united in feeling that they would take their employers to an Employment Tribunal should they ever be discriminated against on the grounds of their HIV status. The common theme was that by that point in time there would be nothing for them to lose. Thus, $\mathrm{P}$ who had disclosed stated:

I feel they need to worry [laughs] if they misbehave ...I would fight tooth and nail because I would have nothing to lose at that point

P, 43 year old, Man who has sex with other men

Similarly F who had not disclosed stated:

If I lost my job because of my status, I would soon take them to court. [laughs] Because that's not fair...I think once it was out and if I had lost my job anyway, you've got nothing to lose really

F, 32 year old, Heterosexual Woman not born in Africa

Participants were fully aware of the difficulties of enforcing their rights under the EA 2010. Whilst the prevailing theme was that it was good for PLHA to be given the right to be protected from discrimination 'on paper', it was recognised that the enforcement of that right was rather more complex. This was felt to be due to various factors including the ambiguous nature of some parts of the legalisation, unwillingness for representatives to take on claims which lacked a clear chance of success, the intimidating nature of Tribunal proceedings and the unequal balance of power in the employment relationship:

It's all very well to say, OK, people have their rights in terms of disability protection... but then if employers suddenly start realising that really, nobody realistically is going to be able to exercise those rights, then it becomes almost a useless piece of legislation....Employers have a lot of power ...Y You could end up with a very empty piece of [laughs] legislation.

U, 46 year old, Heterosexual Woman not born in Africa

\subsection{AWARENESS AND EXPERIENCES OF PLHA IN RELATION TO}




\section{REASONABLE ADJUSTMENTS}

Very little pre-existing literature exists on PLHA requesting reasonable adjustments. ${ }^{706}$ Douglas's study of MSM in the UK found that the most commonly requested adjustments were time off for clinic appointments, a change in hours worked and a change to start/finish times. ${ }^{707}$ In a French study, Dray-Spira and others found that the most frequently reported adjustments were alleviation of work demands, changing to another position, or changing to part-time hours. ${ }^{708}$ Yet whilst the intention was to talk with participants solely about reasonable adjustments that they had requested and/or received under the auspices of the EA 2010, it quickly became apparent that many individuals had chosen not to request reasonable adjustments from their employer. Instead, they had opted to choose to make their own personal, informal adjustments to their working patterns and practices. For example, participants often chose not to disclose the nature of the hospital appointments they attended:

The only thing I have to lie about is, I go to the hospital twice a year and I just say, "I'm going to the doctors," rather than, "I'm going to the hospital." That's, that is the, the extent of how much it affects my work.

G, 36 year old, Heterosexual Woman not born in Africa

Participants were extremely aware that they could experience a period of ill health at some point in the future. Many had adjusted their working lives to incorporate an extreme reluctance to take time off from work. Although $\mathrm{H}$ had disclosed his status to employers, he was reluctant to take sick leave for fear of being perceived as weak:

I always made a point of being off sick less than my colleagues, or the people I managed...you don't want to be seen as sickly.

H, 57 year old, Man who has sex with other men

For some this led to questions about how far they could push themselves at work without endangering their health and it was felt that this required some degree of balancing competing interests, namely an individual's desire to succeed at work versus their health:

[I]t's a delicate balancing act I think. A really delicate balancing act, protecting your health and your welfare but also having the ambition to go far in your working life.

And I don't see why HIV should affect my working life but I understand that at some

See 3.2.8 for a discussion of the legal framework with regard to the duty to make reasonable adjustments.

N. Douglas, ' I just get on with it...A study of the employment experiences of gay and bisexual men and black African men and women living with HIV in the UK' (National AIDS Trust 2009).

R Dray-Spira and others, 'Socioeconomic differences in the impact of HIV infection on workforce participation in France in the era of Highly Active Antiretroviral Therapy' (2007) 97 (3) American Journal of Public Health 552. 
points in my life it might do, realistically, regardless of the medication that I'm on or, you know, people do get ill.

M, 23 year old, Man who has sex with other men

Quite correctly the EA 2010 does not prevent an employee from keeping their disability private from their employer. ${ }^{709}$ Yet as discussed in section 4.2.8 a failure to disclose one's HIV status may, as a consequence of Schedule 8, paragraph 20(1)(b) of the EA 2010, mean that an employer owes no duty to make reasonable adjustments. This piece of the EA 2010 states:

(1) A is not subject to a duty to make reasonable adjustments if A does not know, and could not reasonably be expected to know-

(b) [in any case referred to in Part 2 of this Schedule], that an interested disabled person has a disability and is likely to be placed at the disadvantage referred to in the first, second or third requirement.

The extent of this knowledge requirement was considered by the EAT in Secretary of State for the Department for Work and Pensions $v$ Alam, ${ }^{710}$ a case considering the almost identical wording used in the DDA 1995. In Alam Lady Smith stated that two questions needed to be asked in order to consider whether an employer was under a duty to make reasonable adjustments. These were:

1. Did the employer know both that the employee was disabled and that his disability was liable to affect him in the [relevant] manner...? If the answer to that question is: "no" then there is a second question, namely,

2. Ought the employer to have known both that the employee was disabled and that his disability was liable to affect him in the [relevant] manner...?

If the answer to that second question is: "no", then the section does not impose any duty to make reasonable adjustments. Thus, the employer will qualify for the exemption from any duty to make reasonable adjustments if both those questions are answered in the negative. ${ }^{711}$

Similarly in McCubbin v Perth \& Kinross Council ${ }^{712}$ it was emphasised that an Employment Tribunal cannot simply stop at the stage of considering whether the employer was aware of the

\footnotetext{
Equality and Human Rights Commission, 'Employment Statutory Code of Practice' (Equality and Human Rights Commission 2011), para. 6.20 
claimant's disability but needs to separately consider what the employer could reasonably have been expected to know.

The consequence is that if an employer lacks actual knowledge of an individual's disability, they may be under a duty to make enquiries to establish whether a person is suffering from a disability. ${ }^{713}$ The Employment Code of Practice to the EA 2010 provides the following example:

A worker who deals with customers by phone at a call centre has depression which sometimes causes her to cry at work. She has difficulty dealing with customer enquiries when the symptoms of her depression are severe. It is likely to be reasonable for the employer to discuss with the worker whether her crying is connected to a disability and whether a reasonable adjustment could be made to her working arrangements. ${ }^{714}$

Gallop v Newport City Council ${ }^{715}$ represented an opportunity for the Court of Appeal to consider the knowledge requirement further. Although Gallop was another case involving the DDA 1995, the Court of Appeal expressly recognised that the 'answers to the questions raised by the appeal will be relevant also to the like disability discrimination provisions in the Equality Act 2010 , and so the appeal is not concerned with questions of mere historical interest. ${ }^{716}$

Mr Gallop was employed by Newport City Council and had been off work on three separate occasions for stress-related illness and depression. After a number of unsuccessful attempts to return to work, the Council obtained the view of an occupational health advisor whose opinion was that Mr Gallop 'was likely to remain unfit for the foreseeable future, that he was not a candidate for ill-health retirement and that "he is not covered under [the DDA]". ${ }^{717}$ On his return to work after his final period of sickness absence, Mr Gallop was suspended following allegations of bullying and was dismissed several months later. Mr Gallop stated he was a disabled person for the purposes of the DDA. He claimed direct discrimination and a failure to make reasonable adjustments. The Council disagreed that Mr Gallop was disabled and argued that in the event that he was, they did not have the requisite knowledge that he was disabled, given the occupational health advice they had received.

The question before the Court of Appeal was whether the tribunal had misdirected itself in reaching the conclusion that the Council had at no time any knowledge, either actual or constructive, of Mr Gallop's disability and the EAT had erred in upholding the tribunal's

[17]-[18].

Equality and Human Rights Commission, 'Employment Statutory Code of Practice' (Equality and Human Rights Commission 2011), para 6.19.

[2013] EWCA Civ 1583; [2014] I.R.L.R. 211.

ibid, [2].

ibid, [22]. 
approach. The Court found that the tribunal did not perform the task of identifying whether the Council had actual or constructive knowledge of the facts constituting the employee's disability. Lord Justice Rimmer delivering the lead judgment stated:

[41] ...the task for the [Employment Tribunal] was to ascertain whether, at the material times, Newport had actual or constructive knowledge of the...facts constituting $\mathrm{Mr}$ Gallop's disability. The ET did not engage in that inquiry. It considered that Newport was entitled to deny relevant knowledge by relying simply on its unquestioning adoption of [Occupational Health Advisers'] unreasoned opinions that Mr Gallop was not a disabled person. In that respect the [Employment Tribunal] was in error; and the EAT was wrong to agree with the [Employment Tribunal].

[42] This may perhaps seem a hard result, but I consider it follows from the terms of the legislation. The problem with certain types of disability, or claimed disability, is that it is only when eventually the [Employment Tribunal] rules on the question that it is known whether the claimant was in fact a disabled person. In the meantime, however, the responsible employer has to make his own judgment as to whether the employee is or is not disabled. In making that judgment, the employer will rightly want assistance and guidance from occupational health or other medical advisers.

This case demonstrates that whilst advice from third parties engaged by the employer may be relevant to determining if an individual is disabled, ultimately the employer has to exercise their own judgment in order to make this decision. ${ }^{718}$ Whilst these cases demonstrate that employers are required to be mindful of the possibility that an employee who is having difficulty participating at work may be disabled, the comments made by $\mathrm{G}$ and $\mathrm{H}$ above readily illustrate the difficulties of employers being reasonably expected to know of their HIV positive employee's disability. By way of example in British Midland Airways Ltd v Hamed ${ }^{719}$ it was held that a prolonged period of sickness absence might be enough to signal that an individual employee has a disability. Yet, HIV positive employees are no more likely to be absent from work due to ill health than any other employed person. ${ }^{720}$ In addition, the six-monthly hospital appointments described by $\mathrm{G}$ are significantly different from the 52 weeks' sickness absence which ought to have signalled the imposition of a duty to make reasonable adjustments in

The requirement that an employer must have either actual or constructive knowledge of an individual's disability before the duty to make reasonable adjustment arises has recently been re-emphasised by the Court of Appeal in Donelien $v$ Liberata UK [2018] EWCA Civ 129.

719 [2010] UKEAT 0292_10_0311.

$720 \quad$ J Leigh and others, ‘Absenteeism and HIV infection' (1997) 4 (5) Applied Economics Letters 275; James Habyarimana, Bekezela Mbakile and Cristian Pop-Eleches, 'The Impact of HIV/AIDS and ARV Treatment on Worker Absenteeism: Implications for African Firms' (2010) 45 Journal of Human Resources 4. 
Hamed $^{721}$ Further, it would also appear that such hospital appointments lack sufficient proximity to trigger the requisite knowledge requirement for the employer.

Very few participants had requested or received reasonable adjustments under the EA 2010. Indeed, through conducting the research it became apparent that there were a number of barriers to PLHA requesting reasonable adjustments. These were first, a complete lack of awareness of the concept of reasonable adjustments; second, an awareness of the concept of reasonable adjustments but a lack of awareness that PLHA could request them; third, an unwillingness to have reasonable adjustments made for fear of attracting attention to oneself and finally; an unwillingness to disclose one's HIV status in order to obtain reasonable adjustments because of potential stigma and/or discrimination. Thus one participant, S, was not aware of the concept of reasonable adjustments. This has been evidenced before. Douglas found that only two-thirds of respondents were aware of the (then) DDA 1995 and almost a third of these respondents did not know that this entitled them to ask for reasonable adjustments. ${ }^{722}$ However, this level of ignorance was not observed here and the response of $S$ was an unusual one as there was generally awareness of the concept to reasonable adjustments amongst participants. There was, however, much less understanding of the fact that PLHA could request reasonable adjustments. Thus whilst the vast majority of participants were aware of the concept of reasonable adjustments they were unaware that they could request them. The main reason for this lack of knowledge stemmed from the fact that the majority of individuals only perceived reasonable adjustments as being available to those with physical disabilities:

Question - Were you aware of that, the concept of reasonable adjustments?

I was aware, I was aware of that. I hadn't really thought about it applying to HIV J, 42 year old, Man who has sex with other men

This misunderstanding of the concept of reasonable adjustments meant participants thought that in any event adjustments were solely linked to changes to physical features of buildings or premises:

I can't say I'm aware that [the concept of reasonable adjustments] applies to people living with HIV. I guess for people with physical disabilities I am well aware of that, for instance about the ramps for example... But for people living with HIV, I wasn't aware that you could actually require an adjustment be made in the workplace.

R, 38 year old, Heterosexual man born in Africa

721 British Midland Airways Ltd v Hamed [2010] UKEAT 0292_10_0311.

722 N. Douglas, ' I just get on with it...A study of the employment experiences of gay and bisexual men and black African men and women living with HIV in the UK' (National AIDS Trust 2009). 
Of particular note was a comment from one participant which indicated that perhaps the language employed by the EA 2010 in terming PLHA 'disabled' was contributing to this lack of awareness. Hence, the majority of PLHA interviewed were aware of the concept of reasonable adjustments for individuals with disabilities; however, as relatively few perceived themselves as being disabled they did not automatically assume the concept applied to them. $\mathrm{H}$ was particularly knowledgeable about matters relating to HIV and had previously worked for a number of organisations in the HIV sector yet even he failed to make the link. He explained his lack of awareness as follows:

Do you know I never even thought about it like that, even till now, when I've worked with organisations with people around mental health. Making reasonable adjustments for people with mental health difficulties. [laughs] It's very odd, yes. That's probably because I didn't see myself as being disabled.

H, 57 year old, Man who has sex with other men

This accords with the argument that there is a tendency to focus on individuals with physical or sensory impairments when developing reasonable accommodation policies. ${ }^{723}$ As Lawson notes, for most social actors it is easier to identify the obstacles facing individuals with physical or sensory impairments as opposed to those with other impairments. ${ }^{724}$

In terms of overcoming this misunderstanding that reasonable adjustments were solely linked to changes to physical features of buildings or premises, E described how there was a dearth of potential information for PLHA concerning this topic when compared to other disabilities. Here $\mathrm{E}$, who is also dyslexic, describes how his experience of reasonable adjustments in relation to PLHA fundamentally differed to his experience in relation to his dyslexia diagnosis:

Compared to the dyslexia, what was really interesting was that there's a whole load of work needs assessments, specialists out there for dyslexia and work pay for somebody to come and do a full assessment on what I'd benefit from....With HIV, and particularly with potential side-effects, there isn't anything like that.

E, 46 year old, Man who has sex with other men

This is unfortunate as it is not essential for the claimant himself or herself to identify what should have been done. Although as Waddington observes 'the individual with a disability is 
better acquainted with how his disabilities can be overcome', ${ }^{725}$ the process, Lawson notes, should involve a process of interaction and dialogue between the employer and employee in order to provide a specific, individualised solution. ${ }^{726}$ This corresponds with the Employment Code of Practice to the EA 2010 which states:

There is no onus on the disabled worker to suggest what adjustments should be made (although it is good practice for employers to ask). ${ }^{727}$

Indeed the EAT held in Southampton City College $v$ Randall ${ }^{728}$ that a tribunal may find a particular step to be a reasonable adjustment even in the absence of evidence that the claimant had asked for it at the time.

It emerged from the empirical research that another barrier to requesting reasonable adjustments was a fear of attracting attention to oneself. The concept of an individual being reluctant to requesting reasonable adjustments for fear of being perceived as different or indeed as asking for special treatment has been noted in earlier research undertaken in the United States. ${ }^{729}$ One participant described how the mere fact of having adjustments made would cause fellow employees to question this perceived preferential treatment which would only lead to greater numbers of individuals in the workplace becoming aware of the individual's status:

Eventually everybody will know about your status, because, you know, a lot of people will start thinking, why are you having preferential treatment? Seems everything's being adjusted for you, what's your problem?

L, 49 year old, Heterosexual man born in Africa

In addition, the fact that disclosure of an individual's HIV status was required before an employer could be expected to make reasonable adjustments represented a significant barrier to many participants:

L Waddington, 'Reasonable Accommodation' in D Schiek, L Waddington and M Bell (eds), Cases, Materials and Text on National, Supranational and International Non-Discrimination Law (Hart Publishing, 2007), 710.

A Lawson, 'People with Psychosocial Impairments or Conditions, Reasonable Accommodation and the Convention on the Rights of Persons with Disabilities’ (2008) 26 (2) Law in Context 62, 69.

Equality and Human Rights Commission, 'Employment Statutory Code of Practice' (Equality and Human Rights Commission 2011), para 6.24.

[2006] IRLR 18.

D Engel, D and E Munger, 'Rights, Remembrance, and the Reconciliation of Differences' (1996) 30 Law and Society Review 7; B Granger, 'The role of psychiatric rehabilitation practitioners in assisting people in understanding how to best assert their ADA rights and arrange job accommodations.' (2000) 23 (3) Psychiatric Rehabilitation Journal 23(3) 215 . 
I think [reasonable adjustments are] a fantastic idea. But I'm still not going to tell them. [laughs] And you know why I'm not going to tell them, because of the stigma attached to it.

I, 40 year old, Heterosexual man who wasn't born in Africa

Thus when participants were asked for their thoughts on PLHA having to disclose in order to have reasonable adjustments made, $\mathrm{S}$ commented as follows:

Again, I think, disclosure's so massive for, for most people who are HIV positive, and especially in terms of employment, because the last thing you want is to, not be working. So I don't know, I don't know many people who would be happy to disclose to their employer.

S, 33 year old, Heterosexual Woman not born in Africa

One possible solution is to extend the scope of those able to request reasonable adjustments to groups other than solely those with disabilities. In some non-European jurisdictions such a concept exists. Thus in the United States the Civil Rights Act places a duty on employers to, 'reasonably accommodate an employee's religious beliefs or practices, unless doing so would cause more than a minimal burden on the operations of the employer's business. ${ }^{730}$ Whilst section 15 of Canadian Charter of Rights and Freedoms has a general accommodation of difference clause. ${ }^{731}$ Indeed due to the 'potential utility' of the duty to make reasonable adjustments, there is 'an active debate on whether to extend this to other characteristics, such as age, religion or those with caring responsibilities. ${ }^{732}$

By way of example, Sargeant argues in favour of providing the duty to older workers due to the close link between age and disability and the fact that "one of the reasons why older workers suffer from age discrimination is perhaps the fear of employers that they will become disabled". ${ }^{733}$ Similarly, Foblets and Alidadi have argued that, for the purposes of EU law, the concept of reasonable accommodation ought to be extended to the protected characteristic of religion and belief. ${ }^{734}$

$730 \quad$ Civil Rights Act 1964, 42 U.S.C.A. para 2000e j.

731 For further discussion of the duty in areas other than the protected characteristic of disability see L Waddington, 'Reasonable Accommodation: Time to Extend the Duty to Accommodate Beyond Disability?' (2011) 36 (2) NTM|NJCM-Bulletin 186.

732 M Bell, 'Sickness Absence and the Court of Justice: Examining the Role of Fundamental Rights in EU Employment Law' (2005) 21 (5) European Law Journal 641.

733 M Sargeant, 'Older Workers and the need for Reasonable Accommodation'(2008) 9 (3) International Journal of Discrimination and the Law 163, 167.

734 L. Vickers, 'Religion and Belief Discrimination in Employment - the EU law' (European Commission 2006);

M Foblets and K Alidadi 'Summary Report on the RELIGARE Project' (2013)

<http://www.religareproject.eu/?q=content/final-summary-report-religareproject> accessed: 7 July 2017. 
There is no current sound legal argument for an extension of the duty to groups other than individuals with disabilities. The issue was touched upon by the CJEU in Coleman v Attridge Law ${ }^{735}$ who stated that the duty of reasonable accommodation 'would be rendered meaningless or could prove to be disproportionate if they...not limited to disabled persons only. ${ }^{736}$ In this case, the CJEU also made reference to recitals 16 and 20 of the Framework Directive which provide:

(16) The provision of measures to accommodate the needs of disabled people at the workplace plays an important role in combating discrimination on grounds of disability.

$\cdots$

(20) Appropriate measures should be provided, i.e. effective and practical measures to adapt the workplace to the disability, for example adapting premises and equipment, patterns of working time, the distribution of tasks or the provision of training or integration resources.

These recitals indicate that the duty is intended to address the needs of disabled people. Consequently, the duty is "designed specifically to facilitate and promote the integration of disabled people into the working environment and, for that reason, can only relate to disabled people". ${ }^{737}$

Similarly, at the domestic level, the duty to make adjustments has been held not to extend to those associated with disabled individuals in the case of Hainsworth $v$ Ministry of Defence. ${ }^{738}$ In this case, the claimant, Dr Hainsworth, argued before the Court of Appeal that she ought to be permitted an adjustment of moving workplace to enable her 17 year old disabled daughter to be able to undergo training. Dr Hainsworth was employed as a teacher by the Ministry of Defence in Germany and her daughter was a disabled person within the meaning of section 6 of the EA 2010. Whilst the Ministry of Defence provided facilities for the children of personnel serving in Germany, it did not provide any special schools or facilities for children with disabilities. Consequently, Dr Hainsworth requested a transfer to the UK so that her daughter could receive appropriate education. The Ministry of Defence rejected her request and Dr Hainswoth commenced proceedings submitting that the Ministry of Defence were 'obliged to make adjustments to a [provision, criterion or practice] applied to its employee, the claimant, to enable the claimant's disabled daughter (a person associated with the claimant) to undergo

Case C-303/06 Coleman v Attridge Law [2008] ECR I-5603.

ibid, [42].

ibid.

[2014] EWCA Civ 763, [2014] IRLR 728. 
training and education. ${ }^{739}$ The provision, criterion or practice in question was that Dr Hainsworth was required to predominantly provide her services within a military garrison in Germany.

Dr Hainsworth submitted that it would have amounted to a reasonable adjustment to the provision, criterion or practice for the Ministry of Defence to have allowed her a compassionate transfer and to have transferred her employment to the UK. Whilst a purely literal approach to the provisions of the EA 2010 allude to the fact that an employer owes a duty to make reasonable adjustments only in respect of an individual with disabilities, ${ }^{740}$ Dr Hainsworth argued that that the right claimed was given to her by Article 5 of the Framework Directive. ${ }^{741}$ Dr Hainsworth also relied upon the provisions of the United Nations CRPD, noting the case of HK Danmark (Ring and Skouboe Werge) ${ }^{742}$ in which the CJEU decided that the Framework Directive must, as far as possible, be interpreted in a manner consistent with the CRPD. ${ }^{743}$ In particular, Article 24 of the CRPD concerning the right to education and Article 27 concerning the right to work and employment were relied upon.

After referring explicitly to the decision in Coleman, Lord Justice Laws, delivering the lead judgment, came to the conclusion that, '[a]rticle 5 is limited so as to require measures only for the assistance of disabled employees or prospective employees of the employer in question.' Lord Justice Laws also noted that the mere fact 'that the disabled person in Coleman was the employee's child and not the employee herself offers in my judgment no read-across to Article 5 upon which the appellant might rely. ${ }^{744}$ Indeed, in Coleman the claimant was, amongst other matters, subjected to abusive and insulting comments about her disabled son by her employer. As her son's disability was the effective cause of this less favourable treatment, the exact relationship required in an associative discrimination case "was in those circumstances not critical to proof of the cause. ${ }^{745}$ By contrast in Hainsworth it was stated that 'the appellant has to assert a duty upon the respondent to act effectively for the benefit of her child. The proximity of the relationship between the appellant and the disabled person (here her daughter) therefore becomes critical. But Article 5, as I have said, gives no clue as to what degree of proximity might be required. ${ }^{976}$

ibid [2].

See section 4.3.8 for further discussion about the duty to make reasonable adjustments under the Equality Act 2010 Council Directive 2000/78/EC of 27 November 2000 establishing a general framework for equal treatment in employment and occupation [2000] OJ L 303/16. See section 3.4 for further discussion of the Framework Directive. Joined Cases C-335/11 and C-337/11, [2013] 3 CMLR 21.

See section 3.4.1 for discussion of the HK Danmark (Ring and Skouboe Werge) case.

Hainsworth v Ministry of Defence [2014] EWCA Civ 763, [27].

ibid, [27].

ibid. 
In relation to the CRPD, Article 24(1) is limited to 'the right of persons with disabilities to education.' Whilst, concerning reasonable accommodation specifically, Article 24(2)(c) states that, "[i]n realising this right, States Parties shall ensure that [r] easonable accommodation of the individual's requirements is provided.' Article 27(1) contains similar qualifications. Thus Article 27(1) places limits on the scope of the right limiting it to 'the right of persons with disabilities to work, on an equal basis with others'. Article 27(1)(j) also makes clear that States Parties only need '[e]nsure that reasonable accommodation is provided to persons with disabilities in the workplace.' These Articles can be compared with Article 28 concerning 'the right of persons with disabilities to an adequate standard of living for themselves and their families' (emphasis added). ${ }^{747}$ Clearly here there is no restriction on the relevant right applying to solely the individual with a disability.

In view of the above, Lord Justice Laws came to the conclusion that Dr Hainsworth's suggested 'interpretation of Article 5 requires an open-ended and unspecific approach to the identity of the disabled person in the case. That circumstance has, as I have made clear, informed my conclusion that the appellant's interpretation is unsustainable. ${ }^{778}$

The extension of the scope of those able to request reasonable adjustments to groups other than those with disabilities in order to overcome some of the problems associated with disclosing one's HIV status is, it is submitted, a disproportionate response to the problem identified by the empirical research, namely the reluctance of PLHA to disclose their disability. The discomfort associated with requesting reasonable adjustments stems not from the making of the request to the employer itself but from the reason for making that request, i.e. the individual's disability. Indeed, Waddington argues that 'if interpreted dynamically, the obligation not to indirectly discriminate can also provide for a de facto accommodation duty in many cases. ${ }^{949}$ Consequently, the extension of the duty to additional protected groups would do little to assist PLHA in securing reasonable adjustments, whilst undermining the certainty associated with the current legal framework. ${ }^{750}$ What is instead required is amendment to the wording of the EA 2010 to alter the manner in which individuals with disabilities may request reasonable adjustments from their employer. This issue will be explored in section 8.3.2.

\subsection{ATTITUDES OF PARTICIPANTS TO HIV BEING DEEMED A DISABILITY BY THE EA 2010}

Article 28(1) United Nations CRPD.

Hainsworth v Ministry of Defence [2014] EWCA Civ 763, [40].

L Waddington, 'Reasonable Accommodation: Time to Extend the Duty to Accommodate Beyond Disability?' (2011) 36 (2) NTM|NJCM-Bull. 186, 197.

ibid. 
Participants were asked their opinions as to the decision to automatically classify PLHA as disabled for the purposes of the EA 2010 and whether or not they agreed with this. In general participants were pleased with the legal protection that being classified as disabled brought them. Overwhelmingly though, whilst welcoming of the protection of the EA 2010, PLHA did not perceive themselves to be disabled as this exchange with E illustrates:

Question - Do you think that's a good idea [to be afforded legal protection]?

I do, yes... And just to know that you are covered...that you are able to call on those rights if you are being discriminated against, I think is a huge advantage... So I think, I think having HIV in that category is really powerful.

Question - Would you consider yourself to be disabled?

No. [laughs] I, I don't, but I do like the protection that it gives me.

E, 46 year old, Man who has sex with other men

$\mathrm{H}$ agreed that he was disabled but made a distinction between disabled for legal purposes and society as a whole. In his opinion, he was disabled for the purposes of the law only:

I consider myself to be disabled in terms of the law.

Question - Why the distinction?

Well, I, but I don't know what it would feel like to feel disabled. I can only know what it feels like to be me in my circumstances. And, I don't feel disabled.

$\mathrm{H}, 57$ year old, Man who has sex with other men

Key themes emerged in relation to PLHA being unwilling to think of themselves as disabled. The prevailing theme was that participants perceived individuals with disabilities as individuals with physical and/or sensory impairments. Unfortunately, amongst the majority of participants the stereotypical view of individuals with disabilities as being those who were less able or capable persisted:

Maybe my perception of disability is, is way out there, but then... But disabled to me would mean someone who is, whose ability to do something has been impaired.

R, 38 year old, Heterosexual man born in Africa

The fact that participants did not want to identify as disabled may not be entirely unsurprising. The concept of disability is shrouded in negative preconceptions. Disability is often 
stereotypically portrayed as a concept that limits employability and thus threatens social standing and self-respect. ${ }^{751}$

Stereotyping of individuals with disabilities was deep rooted amongst participants. Stereotypes are beliefs about the characteristics of groups of people ${ }^{752}$ and it has been theorised that stereotyping is a deep-rooted, biologically embedded process that allows individuals to categorise others and make rapid judgments in a complex world. ${ }^{753}$ Yet the price of such a short cut is however an unfair 'pigeon-holing' of individuals into neat categories based on little or no consideration of the characteristics of specific individuals. ${ }^{754}$ The harm of this stereotyping is that it ties individuals with disabilities down to a particular identity. A stereotypical perception of a particular group, including individuals with disabilities, places a preconceived mould on all individuals within that group notwithstanding who they are, what they are capable of or what they experience or desire. ${ }^{755}$ Individuals with disabilities are perceived by both society as a whole and indeed some of the participants in this study, not as individuals but on the basis of their group membership.

Stereotypes serve to maintain existing power relationships; they are control mechanisms and uphold a symbolic and real hierarchy between 'us' and 'them'. Validating this theory participants emphasised the hierarchy between themselves and individuals with disabilities by accentuating various differentiating factors. Thus, physical prowess and a feeling that their capabilities had not diminished were themes used to differentiate participants from individuals with disabilities:

I mean, do I look disabled? [laughs]...I'm fit and healthy, I can run up and down the stairs, I can do all the hiking that I used to do before I was admitted to hospital. I do not feel in the least bit disabled.

I, 40 year old, Heterosexual man who wasn't born in Africa

I can run faster than most guys my age, I climb mountains steeper and higher than most guys my age. I just, you know, to say that people who are positive are disabled is totally missing the point.

D Engel and F Munger, Rights of Inclusion : Law and Identity in the Life Stories of Americans with Disabilities (University of Chicago Press 2010).

C Stangor, Stereotypes and Prejudice: Essential Readings (Psychology Press 2000).

W Lippmann, Public Opinion (BN Publishing 2007).

P Quinn and P De Hert, 'Self respect-A “Rawlsian Primary Good"' unprotected by the European Convention on Human Rights and its lack of a coherent approach to stigmatization?' (2014) 14 (1) International Journal of Discrimination and the Law 19.

A Timmer, 'Toward an Anti-Stereotyping Approach for the European Court of Human Rights' (2011) 11 (4) Human Rights Law Review 707. 
These comments illustrate that PLHA reinforce stereotypical views of individuals with disabilities. Yet as the term 'disability' is notoriously difficult to define, it is perhaps surprising that stereotyping of individuals with disabilities is prevalent to such an extent. Disability can refer to an enormously diverse array of conditions. Common understandings of disability embrace conditions ranging from deafness to quadriplegia, from epilepsy to cancer, from mental illness to heart conditions. Any attempt at a coherent conception of disability is also compounded by the fact that people may acquire these conditions at different stages of their life. ${ }^{756}$ In addition, the severity of these conditions also varies significantly as does the manner in which individuals interact and experience these conditions. Linked to this is the fact that 'our real human bodies are exceedingly diverse - in size, shape, colour, texture, structure, function, range and habits of movement, and development - and they are constantly changing. ${ }^{757}$ With this in mind, it is perhaps surprising that the participants interviewed, in common with society as a whole, are able to conceive of one single vision of what disability is and what attributes individuals with disabilities have - in their opinion, individuals who are less physically capable than a 'normal' person.

Many felt that there was a certain element of stigma to being involuntarily labelled as disabled and they did not like the negative perceptions and, for want of a better expression, baggage associated with disability:

I'd be insulted to be thought of as disabled...because I'm a management consultant, ...it's a wrong diagnosis of the situation. I am positive, yes, but I am disabled, no. And again, disabled brings along another load of baggage, like you're expected to be in a wheelchair or on crutches or have a wooden leg or be blind or deaf

C, 52 year old, Heterosexual man not born in Africa

In a society that idealises the body, the comments of $\mathrm{C}$ above illustrate the distaste that individuals have when finding themselves thought of by others as disabled. In our society, the disabled are marginalised and Wendell asserts that people learn to identify their own strengths and to hate, fear and neglect their own weaknesses. ${ }^{758}$ This theory holds true with the interviews conducted with PLHA; in an attempt to demarcate a clear boundary between themselves and individuals with disabilities many emphasised their strengths in terms of physical prowess by means of running, climbing or participation in other physical activities. Indeed, individuals with disabilities are not only diminished for their devalued bodies, ${ }^{759}$ they constantly remind the able-

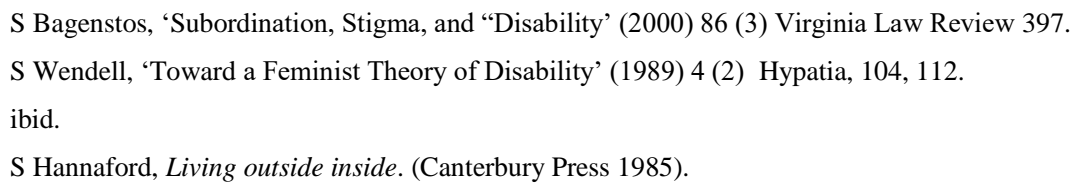


bodied of what they are trying to avoid, forget and ignore. ${ }^{760}$ Thus, as Wendell eloquently puts it:

For example, if someone tells me she is in pain, she reminds me of the existence of pain, the imperfection and fragility of the body, the possibility of my own pain, the inevitability of it...I want to believe I am not like her, I cling to the differences. Gradually, I make her “other” because I don’t want to confront my real body, which I fear and cannot accept. ${ }^{761}$

As PLHA do not wish to acknowledge the inevitability and permanence of the virus within their bodies, the fragility of their bodies and the subtle stigma and discrimination they are now confronted with from other members of society, they are reluctant to embrace any possible weaknesses or foibles that being HIV positive brings and so are loath to identify themselves as disabled. The concern is that the label 'disabled' would pull individuals away from what they perceive to be the norm:

Whereas this just lumps you in with everyone living with cancer and bloody god knows what...And I'm like, I don't think it's like that. I don't think that we should be lumped in with people like that, because, a lot of people aren't ill.

G, 36 year old, Heterosexual Woman not born in Africa

Some participants felt that automatically classifying PLHA as disabled portrayed an outdated view of HIV and ignored the reality that with access to effective medication PLHA are able to enjoy near normal lifespans and good health. ${ }^{762}$ PLHA were acutely aware of the manner in which HIV and AIDS had been portrayed in the 1980s and the stigma that had resulted from this:

[Disability] just reinforces all the stereotypes of like, oh you've got AIDS, you're going to die...Like, from the Eighties and stuff.

G, 36 year old, Heterosexual Woman not born in Africa

As a final point, it was acknowledged by many that there were limits to what the law could achieve in order to reduce discrimination and stigma against PLHA:

J Lessing, 'Denial and Disability' (1981) 11 (5) Off our Backs 21.

S Wendell, 'Toward a Feminist Theory of Disability’ (1989) 4 (2) Hypatia, 104, 113.

J A Sterne and others, 'Long-term effectiveness of potent antiretroviral therapy in preventing AIDS and death: a prospective cohort study'(2005) The Lancet 378; Hasina Samji and others, 'Closing the Gap: Increases in Life Expectancy among Treated HIV-Positive Individuals in the United States and Canada' (2013) 8 (12) PLoS ONE < https://doi.org/10.1371/journal.pone.0081355> accessed 13 November 2017. 
It's one thing to say, you cannot discriminate against them, but if a person has a fear of people living with HIV, legislation isn't going to take that away.

$\mathrm{R}, 38$ year old, Heterosexual man born in Africa

Following on from this were comments made by a number of participants which illustrated their desire for greater awareness of HIV amongst the general population. It was clear from participants' comments that knowledge of HIV amongst the majority of the general population was very poor and based on incorrect or out of date information. A lack of knowledge of the virus led to situations where individuals were either poorly managed at work or subjected to discrimination because employers and line managers made incorrect assumptions about the risks associated with employing PLHA. O and $\mathrm{U}$ who both worked in the HIV sector recounted experiences when friends or colleagues with HIV had been subjected to discrimination:

And so, I think that's the difficulty, when you get somebody that has that ignorance and an outdated mindset around and perception of HIV, then that's when the shit hits the fan unfortunately...So, it's, it's that combination of ignorance and fear together I think is just such a horrible one

$\mathrm{O}, 45$ year old, Man who has sex with other men

And there are all these misconceptions, that people with HIV [are] going to take loads of time off sick... you can't share cups with them....All these silly, silly things that you can't seem to educate people no matter how much you can try.

U, 46 year old, Heterosexual Woman not born in Africa

Unfortunately this lack of knowledge about the virus leads to poor management of PLHA. There is still considerable work to be done in conjunction with employers to educate them about the EA 2010 and ensure that all individuals with disabilities are able to participate in work on as equal a basis as possible.

Overall though individuals rejected the concept of 'disability' because of its association with a system of society in which those who are physically or mentally impaired are subjugated and expected to perform in the sick role. ${ }^{763}$ Whilst the rejection of the label is stark, it is not entirely without precedent. Watson conducted research into the identity of individuals with disabilities and undertook an interview based study with 14 disabled men and 14 disabled women. These individuals were recruited through organisations of and for disabled people, housing associations and sports clubs. Watson discovered that despite daily experiences of oppressive 
practices, only three of the participants incorporated disability within their identity. ${ }^{764}$ In his words, the majority of participants who rejected the label, 'are creating an idea of themselves for themselves. They are not basing their ideas of self-identity on biomedical models that present disability as a tragedy. ${ }^{7} 765$

The decision to deem PLHA disabled was almost universally unpopular amongst participants and can be seen as an example of 'AIDS exceptionalism'. ${ }^{766}$ This concept stems from the idea that, in the 1980s, the virus became, 'the exception from many rules in health policy, prevention and patient care.' AIDS exceptionalism began as a Western response to the original lethal nature of the virus which disproportionately affected specific groups. ${ }^{767}$ It was argued that HIV/AIDS required an exceptional response in order to protect the rights of those infected, to generate resources to assist them and to the epidemic. ${ }^{768}$ To combat the virus, the law was also employed to 'protect persons living with HIV/AIDS from social risks, stigma and other adverse consequences by respecting privacy and prohibiting unwarranted discrimination. ${ }^{769}$ Stigma it was feared 'would drive people with HIV underground, alienating them from social support and public health authorities, deterring testing, and undermining the effectiveness of HIV prevention efforts. ${ }^{770}$

However, as Hamblin argues, 'an appropriate legal response to HIV/AIDS will most often have as its desired outcome the absence rather than the presence of applicable law. ${ }^{, 771}$ An approach the EA 2010 declines to take. In addition, from a public health perspective, England argues that HIV/AIDS was not the 'global catastrophe' claimed by AIDS exceptionalists ${ }^{772}$ and that:

It is no longer heresy to point out that far too much is spent on HIV relative to other needs and that this is damaging health systems. Although HIV causes 3.7 percent of mortality, it receives 25 percent of international healthcare aid and a big chunk of domestic expenditure. ${ }^{773}$ and disability' (2002) 17 (5) Disability \& Society 509. ibid, 521.

R Bayer, 'Public Health Policy and the AIDS epidemic: An end to HIV exceptionalism' (1991) 324 New England Journal of Medicine 1500 . 47.

ibid.

L Gable, 'Global Assessment of the Role of Law in the HIV/AIDS Pandemic' (2009) 123 Public Health $260,261$. S Burris, 'Studying the Legal Management of HIV-Related Stigma' (1999) 42 (7) American Behavioural Scientist 1229. J Hamblin, 'The role of law in HIV/AIDS policy’ (1991) 5 (Suppl 2) AIDS S239.

R England, 'The dangers of disease specific aid programmes' (2007) 335 British Medical Journal 565.

R England, 'Writing is on the wall for UNAIDS' (2008) 336 British Medical Journal 1072.
} 
Coupled with this is the fact that ' $[\mathrm{p}]$ revention, research and patient care have become routine matters, interrupted by new clinical advances in the field of therapy promising to make AIDS a chronic illness with long survival times. ${ }^{774}$ The consequence of this is that there is now discussion about the end of exceptionalism. ${ }^{775}$ Yet the EA 2010's construction of HIV as a disability from the point of diagnosis marks PLHA as exceptions to the current section 6 construction of disability. Based upon the empirical research undertaken, there appears to be little appetite for such an approach amongst PLHA. It is of course apparent that PLHA may be subject to stigma and discrimination but not all PLHA who took part in this research were subjected to stigma and discrimination. Discussion has already been made of how discrimination against PLHA operates in a socially differentiated manner ${ }^{776}$ and as the empirical research illustrates a number of participants experienced neither substantial functional nor societal adverse effects. As such, there appears to be little logic in deeming such individuals disabled when their impairment has little impact upon them. Indeed, it appears contrary to the rules of natural justice to place such individuals in a more favourable position than those with other conditions which may attract similar levels of stigma but not be afforded the automatic protection of the EA 2010. By way of example, an extensive body of literature has documented the high levels of stigma associated with mental illness ${ }^{777}$ It is therefore submitted that HIV should not be afforded automatic protection as a disability under the EA 2010 and that instead the wording of section 6 of the EA 2010 ought to be amended to adequately protect only those PLHA who are prevented from participating in society as a result of the stigma and discrimination they face. This proposal will be developed and further explored in Chapter 8 .

\subsection{CONCLUSION}

In the EA 2010, the definition of disability serves a gatekeeping function. It grants access to the full protection of disability discrimination law only to those people it classifies as being or having been disabled. ${ }^{778}$ If a person wishes to bring a claim of disability discrimination, they must first establish that they have a disability as defined in the EA 2010. For the majority of individuals, this involves a consideration of whether they meet the definition of disability as

R. Rosenbrock and others, 'The normalization of AIDS in Western European countries' (2000) 50 Social Science \& Medicine 1607, 1608.

R Bayer, 'Public Health Policy and the AIDS Epidemic. An End to HIV Exceptionalism?' (1991) 324 JAMA 1500; R Bayer and A Fairchild, 'Changing the Paradigm for HIV Testing — The End of Exceptionalism' (2006) 355 New England Journal of Medicine 647.

R Dray-Spira and others, 'Socioeconomic differences in the impact of HIV infection on workforce participation in France in the era of Highly Active Antiretroviral Therapy’ (2007) 97 (3) American Journal of Public Health 552. University Press 2006). 
employed by section 6 of the EA 2010. Yet PLHA are different. They do not have to go through the hurdle of proving themselves to be disabled within the meaning of section 6 as they are deemed to be disabled from the point of diagnosis due to paragraph 6 to Schedule 1 of the EA 2010. However, the overwhelming theme to emerge from the research was that PLHA disagreed, sometimes quite vehemently, with the decision to classify them as, in effect, automatically disabled for the purposes of the EA 2010. The primary reason for this was that PLHA viewed disability as a concept to be constructed very much along the lines of the medical model. Thus in the words of $\mathrm{C}$, 'disabled people are people in wheelchairs, people with wooden legs, people who are blind, people who are deaf. They are disabled.' The majority of the PLHA interviewed focused on the fact that as their HIV had little or no functional impact, they were not disabled.

As a consequence of the above, the current manner in which the EA 2010 protects PLHA requires amendment. A number of PLHA objected to being involuntarily classified as disabled by the Act. Further, a number of participants experienced neither substantial functional nor societal adverse effects and it appears inexplicable to place such individuals in a more favourable position than those with other similarly stigmatised conditions. ${ }^{779}$ It is therefore submitted that HIV should not be afforded automatic protection as a disability under the EA 2010. Instead, the definition of disability in section 6 of the EA 2010 ought to be amended. Such an approach would also, as will be demonstrated in Chapter 8, ensure that the definition of disability employed by the EA 2010 is more closely aligned with both the United Nations CRPD and EU law. The manner in which the definition of disability employed by the EA 2010 could be amended so that it represents an adequate response to the issues faced by PLHA and is consistent with both international and European legal obligations will be explored in detail the next chapter.

Finally, very few participants had requested or received reasonable adjustments under the EA 2010. This was due to a number of barriers including a lack of awareness of the concept of reasonable adjustments, an unwillingness to have reasonable adjustments made for fear of attracting attention to oneself and an unwillingness on the part of participants to disclose their HIV status in order to obtain reasonable adjustments. However, allowing an extension of the scope of those able to request reasonable adjustments would do little to assist PLHA in securing the same whilst undermining the certainty associated with the current legal framework. There is, in addition, no rationale either under the United Nations CRPD or EU law to support the extension of those able to request reasonable accommodations. It is submitted that instead the EA 2010 requires amendment in order to alter the manner in which reasonable adjustments may 
be requested. Again, the manner in which this could be achieved will be explored in the next chapter.

The next chapter, the conclusion to this thesis, will build upon the issues identified in this chapter and specifically address the adequacy of the UK's current legal framework in relation to PLHA. In addition, it will offer recommendations as how best to refine legal protection for PLHA in this area in order to ensure that the UK's approach accords with both the experiences and wishes of PLHA and the UK's legal obligations. 


\section{CHAPTER 8: CONCLUSIONS}

\subsection{INTRODUCTION}

The purpose of this research was to explore and critically evaluate the extent to which the Equality Act 2010 (EA 2010) protects People Living with HIV or with AIDS (PLHA) within an employment relationship from discrimination. Specifically, it sought to identify whether the current legal framework, which deems all PLHA to be disabled, represents an adequate response to the issues affecting PLHA and is consistent with both international and European legal obligations.

The main finding to emerge from the research was that the manner in which PLHA receive protection from discrimination under the EA 2010 requires reworking in order to accurately reflect the issues faced by PLHA and, in addition, incorporate the social model of disability into domestic law. As PLHA are automatically deemed to be disabled by paragraph 6 to Schedule 1 of the EA 2010 ('the Deeming Provision'), there is no need for a person with HIV/AIDS to demonstrate that they meet the 'traditional' definition of disability outlined in section 6 of the EA 2010. Consequently, it could be said that the UK goes beyond its obligations in respect of PLHA, as both from an international and European perspective, neither the United Nations Convention on the Rights of Persons with Disabilities (CRPD) nor Council Directive 2000/78/EC of 27 November 2000 establishing a general framework for equal treatment in employment and occupation [2000] OJ L 303/16 ('Framework Directive') provide automatic protection for PLHA on the grounds of disability. Instead, with regard to the Framework Directive PLHA must satisfy the definition of disability developed by the CJEU in HK Danmark (Ring and Skouboe Werge) $)^{780}$ if they are to acquire protection on the grounds of disability for the purposes of EU law.

However, at the domestic level, the decision to classify all PLHA as, in effect, automatically disabled from the point of diagnosis was extremely unpopular amongst participants who took part in the empirical research. These participants felt that the decision did not represent an adequate response to the issues faced by them as they primarily viewed disability as a concept to be constructed very much along the lines of the medical model. Therefore in the words of $\mathrm{C}$, 'disabled people are people in wheelchairs, people with wooden legs, people who are blind, people who are deaf. They are disabled.' Indeed, the majority of the PLHA interviewed focused on the fact that as their HIV had little or no functional impact, they were not disabled. Coupled with these criticisms was the discovery that in addition to experiencing little or no functional 
impairment, some PLHA interviewed experienced little stigma or discrimination. Instead, through the analysis undertaken of the passage of the EA 2010 through Parliament, it appears that the automatic protection afforded to PLHA by the Deeming Provision was a somewhat rushed legislative process and represented a rather blunt method of attempting to use the social model of disability for PLHA by attempting to acknowledge the stigma surrounding HIV. In light of this, it is argued that the automatic disability designation afforded to PLHA by paragraph 6 to Schedule 1 of the Equality Act 2010 ought to be removed.

However, the intention of removing the Deeming Provision from the EA 2010 is not to deny the fact that stigma is still unfortunately a problem for some PLHA. Rather, it is an attempt to reflect the fact that stigma is not a problem for all PLHA all of the time, which was in effect the consequence of paragraph 6 to Schedule 1 of the EA 2010. As seen by the empirical research undertaken, stigma against PLHA operates in a socially differentiated manner. Thus, the majority of black African participants were employed in low paid, manual positions and were subjected to stigma as opposed to the MSM participants, who were overwhelmingly white, employed in professional occupations and who were not the subject of discrimination or stigma in their careers.

The problem clearly is that if the Deeming Provision is removed from the EA 2010, PLHA who are subjected to stigma must instead rely on the 'traditional' definition outlined at section 6 of the EA 2010 in order to establish that they are disabled for the purposes of the Act. A complication arises here due to the fact that the definition of disability in section 6 is firmly rooted in the medical model of disability and pays no heed to the social model of disability which has informed the development of the definition of disability at both the international level, through the United Nations CRPD, and the EU level, through the Framework Directive. This failure of the definition used in section 6 to acknowledge the social model of disability means that the definition of disability at the domestic level continues to be primarily focussed on physical restrictions as opposed to societal restrictions. For PLHA, this means that due to the advances in treatment options in relation to HIV, it is unlikely many would satisfy section 6 definition based solely on their physical restrictions. ${ }^{781}$ To counter this, it is argued that the definition of disability expounded by section 6 of the EA 2010 needs to be redrafted in order to take into account societal restrictions in addition to physical restrictions. This would allow for a more nuanced approach to be taken to the question as to which PLHA ought to qualify from protection on the grounds of disability. By way of example, those participants in the empirical research, for example $\mathrm{E}$ and $\mathrm{J}$, who experience no functional restriction due to their HIV and experience no societal restrictions would fail to satisfy the new definition of disability. In contrast, individuals with no functional restriction due to their HIV but who experience societal 
restrictions would qualify, for example a number of the black African participants in this research such as D and $\mathrm{K}$.

By taking the social model into account a future definition of disability in the EA 2010 could more accurately reflect the definition of disability at both the international and European level. In addition, although the future section 6 definition should be based on our international and European obligations, it is important to note that the definition of disability employed by section 6 will need to be wider in terms of scope than the definition developed by the CJEU in relation to the Framework Directive. This is due to the fact that whilst the EA 2010 provides protection against discrimination in the sphere of employment, premises, services and public functions, education and associations; the Framework Directive provides protection against discrimination only in the sphere of employment, vocational guidance and training, and membership of professional, workers' and employers' bodies.

This chapter will now consider the above issue in greater depth before recommending a proposed form of wording for a new definition of disability for the EA 2010 which more accurately represents the wishes of PLHA whilst fulfilling the UK's legal obligations. The second section of this chapter will then consider the associated issue of the adequacy of the current framework of prohibited conduct under the EA 2010 focussing particularly on the concepts of multiple discrimination and reasonable adjustments. The third section addresses the overarching issue of stigma against PLHA and the limits of the current normative framework in combating stigma towards PLHA.

\subsection{THE MANNER IN WHICH PLHA ARE PROTECTED: THE EQUALITY ACT'S DESIGNATION OF PLHA AS DISABLED}

The most significant finding to emerge from the research was that the manner in which PLHA are protected by the EA requires amendment. As detailed in section 4.2, paragraph 6 to Schedule 1 of the EA 2010 states:

(1) Cancer, HIV infection and multiple sclerosis are each a disability.

(2) HIV infection is infection by a virus capable of causing the Acquired Immune Deficiency Syndrome.

When considered from a purely normative perspective, the designation of PLHA as disabled by paragraph 6 to Schedule 1 of the EA 2010 appears to go beyond the UK's obligations in respect of PLHA as neither the United Nations Convention on the Rights of Persons with Disabilities or the Framework Directive provide automatic protection for PLHA on the grounds of disability. By doing this, it could be said that the EA 2010 removes the confusion that has arisen at the 
international level as to whether PLHA should acquire protection from discrimination on the basis of disability, health status or indeed membership of a vulnerable group. ${ }^{782}$ The manner in which the EA 2010 clearly demarcates PLHA as disabled removes any such confusion from domestic law. In addition, the motivation for protecting PLHA in this manner was in recognition of the stigma surrounding HIV, as evidenced by analysis undertaken of the Parliamentary debates surrounding the decision to deem HIV a disability. ${ }^{783}$

However, the decision to classify all PLHA as, in effect, automatically disabled from the point of diagnosis was extremely unpopular amongst participants for the reasons outlined in section 7.4. These reasons were that many PLHA were unwilling to think of themselves as disabled. It was also felt by participants that the EA 2010's automatic designation of PLHA as disabled portrayed an outdated perception of PLHA and contributed further to the already high levels of stigma against PLHA. Therefore, in the words of G, '[Disability] just reinforces all the stereotypes of like, oh you've got AIDS, you're going to die...Like, from the Eighties and stuff.' Instead of the approach taken by the Deeming Provision, PLHA primarily viewed disability as a concept to be constructed very much along the lines of the medical model. Thus, the majority of the PLHA interviewed focused on the fact that as their HIV had little or no functional impact, they were not disabled. Indeed, some participants emphasised their physical prowess to illustrate the fact that they were not disabled. As $\mathrm{C}$ stated, 'I can run faster than most guys my age, I climb mountains steeper and higher than most guys my age. I just, you know, to say that people who are positive are disabled is totally missing the point.' Allied with these criticisms was the discovery that in addition to experiencing little or no functional impairment, some PLHA interviewed experienced little stigma or discrimination. In light of this, it is recommended that HIV no longer should be deemed a disability by Schedule 1, paragraph 6 of the EA 2010. Thus, the new wording of Schedule 1, paragraph 6 would be:

(1)Cancer and multiple sclerosis are each a disability.

Paragraph 6(2) of the EA 2010 which defines HIV infection as being 'infection by a virus capable of causing the Acquired Immune Deficiency Syndrome' would obviously also need to be deleted.

The recommendation that HIV no longer be deemed to be a disability from the point of diagnosis does not refute the fact that some PLHA are still subject to discrimination and stigma. However, rather than deeming all PLHA to be disabled, it is proposed that the definition of disability in section 6 of the EA 2010 be amended to more accurately reflect the social model of disability, drawing on the provisions of the CRPD and the Framework Directive. Such an amendment 
would enable PLHA to acquire protection on the basis of disability should they meet the requisite criteria either through means of the functional effects of their impairment or the stigma directed towards them. By doing this, PLHA would no longer be involuntarily labelled as disabled by the EA 2010, rather they could engage with the Act on an individual basis and be classified as disabled provided they met the amended definition of disability. This, of course, relies on section 6 of the Act being fit for this purpose, i.e. that it complies with the UK's international and European legal obligations. This is the issue that will now be addressed.

As detailed in sections 3.2.5, 4.2 and 7.4, the definition of disability currently employed in section 6 of the EA 2010 relies very much on the medical model of disability. Thus, an individual's impairment must have a 'substantial and long-term adverse effect on [their] ability to carry out normal day-to-day activities. ${ }^{784}$ This stands in contrast to the definition of disability employed by the CRPD and that developed by the CJEU, most notably in the case of $H K$ Danmark (Ring and Skouboe Werge). ${ }^{785}$ The approach taken by the CRPD and the CJEU relies substantially on the social model of disability. Consequently, the CRPD recognises that 'disability results from the interaction between persons with impairments and attitudinal and environmental barriers that hinders their full and effective participation in society on an equal basis with others. ${ }^{786}$ Whilst in HK Danmark it was stated that:

the concept of 'disability' must be understood as referring to a limitation which results in particular from physical, mental or psychological impairments which in interaction with various barriers may hinder the full and effective participation of the person concerned in professional life on an equal basis with other workers. ${ }^{787}$

The EA 2010 is the UK's legislation implementing the Framework Directive. Yet it is apparent that the definition of disability employed by section 6 is not fully compliant with the definition employed by the Framework Directive. EU law is supreme, which means that, in areas where the EU has competence, it has the status of a superior source of law within the EU's member states. ${ }^{788}$ Domestic laws must give way and be disapplied by domestic courts if they are found to be inconsistent with EU law. This core principle of EU law was established in the case law of the CJEU before the accession of the UK to the European Communities and made clear in the judgment of the CJEU in Costa $v$ ENEL. ${ }^{789}$ In the UK, EU law is given legal effect through the European Communities Act 1972. Section 2(1) of the European Communities Act 1972

s6(1)(b) Equality Act 2010.

Joined Cases C-335/11 and C-337/11, [2013] 3 CMLR 21.

at para (e)

ibid, para 38 .

Case C-6/64 Costa v ENEL [1964] ECR 585; Factortame v Secretary of State for Transport (No 2) [1991] 1 AC 603 (HL).

$789 \quad$ Case C-6/64 Costa v ENEL [1964] ECR 585 
provides that 'all rights, powers, liabilities, obligations and restrictions' created or arising in EU law, which are to be given immediate legal effect in national law, 'shall be recognised and available in law, and be enforced, allowed and followed accordingly'.

Following the referendum on the UK's membership of the EU, ${ }^{790}$ it is anticipated that the UK will formally leave the EU in $2019 .{ }^{791}$ Until then, and pending repeal of the European Communities Act 1972, the Framework Directive will continue to have the effect provided for in the treaties. It has also been confirmed in the White Paper, issued by the Government immediately after formal notice to leave the EU was given under Article 50 of the Treaty on European Union, that following repeal of the 1972 Act, legislation implementing EU obligations in domestic law will be introduced with the effect that such obligations will continue in force unless and until amended or repealed by UK legislative action. ${ }^{792}$ It is probable that this will mean that courts will continue to refer to the Framework Directive to clarify the meaning of the EA 2010. In addition, in their concluding observations on the initial report of the UK, the United Nations Committee on the Rights of Persons with Disabilities recommended that the UK '[p]revent any negative consequences for persons with disabilities by the decision of the triggering article 50 of the Treaty on European Union, in close consultation with organizations of persons with disabilities. ${ }^{793}$ In conjunction with this is the United Nations Committee on the Rights of Persons with Disabilities recognition that the definition of disability employed by section 6 fails to fully comply with the United Nations CRPD as evidenced by their recommendation that the UK should '[a]dopt legally binding instruments to implement the concept of disability, in line with article 1 of the Convention and ensure that new and existing legislation incorporate the human rights model of disability across all policy areas and all levels and regions of all devolved government and overseas territories'. ${ }^{794}$

As the definition of disability employed by the EA 2010 relies on the medical model of disability, traditionally domestic courts and tribunals have focussed exclusively on the impact of an impairment on 'normal day to day activities' as per section 6 of the Act. ${ }^{795}$ Yet there is some evidence at the domestic level of tribunals interpreting both the DDA 1995 and EA 2010 in a

The Electoral Commission, 'EU referendum results' (15 August 2016) < https://www.electoralcommission.org.uk/findinformation-by-subject/elections-and-referendums/past-elections-and-referendums/eu-referendum/electorate-andcount-information> accessed 14 December 2017.

P McClean, 'Brexit timeline: key dates in UK's divorce with EU' Financial Times (London, 14 June 2017)

Department for Exiting the European Union, The United Kingdom's exit from, and new partnership with, the European Union (White Paper, Cm 9417, 2017) ch 1.

UN Committee on the Rights of Persons with Disabilities, Concluding Observations to Concluding observations on the initial report of the United Kingdom of Great Britain and Northern Ireland , adopted at the 365th session (29 August 2017), UN Doc. CRPD/C/GBR/CO/1 available at <http://tbinternet.ohchr.org/_layouts/treatybodyexternal/Download.aspx?symbolno=CRPD $\% 2 \mathrm{fC} \% 2 \mathrm{fGBR} \% 2 \mathrm{fCO} \% 2 \mathrm{f}$ 1\&Lang=en> accessed 18 December 2017, [7(f)]. ibid, [7(c)]. See for example the approach taken in Goodwin v Patent Office [1999] IRLR 4. 
manner consistent with both the United Nations CRPD and the Framework Directive. Thus, the Employment Appeal Tribunal in the cases of Paterson $v$ Metropolitan Police Commissioner, ${ }^{796}$ Chief Constable of Dumfries and Galloway Constabulary $v$ Adams ${ }^{797}$ and Sobhi v Commissioner of Police of the Metropolis ${ }^{798}$ considered that the correct reading of the DDA 1995 was to consider the impact of an impairment upon professional life, as in accordance with Chacón Navas.

In the specific context of the EA 2010 the matter was considered by the Employment Appeal Tribunal in the case of Banaszczyk v Booker Ltd. ${ }^{799}$ In this case, the employee had a long-term back condition. Although he could lift and move items weighing up to $25 \mathrm{kgs}$ in the warehouse in which he worked, he could not meet the employer's expectation that workers would pick 210 cases per hour. In deciding that he was disabled within the meaning of the EA 2010 the EAT came to the conclusion that:

It is plain that the claimant's physical impairment had an adverse effect on his ability to do his work. The first question for the employment judge was whether the activities affected were 'normal day-to-day activities', applying the approach laid down in Paterson and Ring. The facts about his normal day-to-day activities at work were undisputed. He was a warehouse operative lifting and moving goods in part manually and in part by the use of a pallet truck; and the goods might weigh up to $25 \mathrm{~kg}$. This is, in the context of work, a normal day-to-day activity: no-one with any knowledge of modern UK life working life could doubt that large numbers of people are employed to work lifting and moving cases of up to $25 \mathrm{~kg}$ across a range of occupations, including in particular occupations concerned with warehousing and distribution. ${ }^{800}$

The decision contrasts starkly with both a literal interpretation of section 6 of the Act and the Guidance on matters to be taken into account in determining the question of disability ${ }^{801}$ which makes it clear that activities do not fall within the category of normal day-to-day activities 'if they are normal only for a particular person, or a small group of people.' In addition, the Guidance states that it would not be reasonable to regard an '[i]nability to move heavy objects without assistance or a mechanical aid, such as moving a large suitcase or heavy piece of furniture without a trolley' as having a substantial adverse effect on normal day-to-day activities. $^{802}$

[2007] UKEAT 0635_06_2307, [2007] IRLR 763.

[2009] UKEAT 0046_08_0304, [2009] IRLR 612.

[2013] UKEAT 0518_12_0205, [2013] EqLR 785.

[2016] UKEAT 0132_15_0102, [2016] IRLR 273.

ibid, [46].

Office for Disability Issues, Guidance on matters to be taken into account in determining questions relating to the definition of disability (Office of Disability Issues 2011).

ibid, 56. 
However, whilst Banaszczyk v Booker Ltd ${ }^{803}$ illustrates the extent to which the literal wording of section 6 can be stretched to attempt to accommodate the UK's legal obligations, the extent to which courts and tribunals would be amenable to utilising a similar approach to an argument based solely upon an individual's inability to participate in society due to stigma is doubtful. All of the cases to date have concerned interpreting section 6 in a manner which, whilst complying with the United Nations CRPD and the Framework Directive, primarily accommodates the functional limitations of impairments in question as opposed to any societal limitations due to stigma ${ }^{804}$ Hence, although there is a willingness on the part of the tribunals to interpret domestic legislation in a manner consistent with the Framework Directive, and thus indirectly the United Nations CRPD, Hervey and Rostant argue that:

A more satisfactory approach would be to add to the definition in section 6 of the Act by drafting a new subsection (2)(A) "A person also has a disability if he possesses a long-term impairment which, in interaction with any barriers placed by society, hinders his full and effective participation in society." $" 805$

At this juncture, it is appropriate to reiterate the current definition propounded by section 6 of the Act:

(1) A person (P) has a disability if-

(a) P has a physical or mental impairment, and

(b) the impairment has a substantial and long-term adverse effect on P's ability to carry out normal day-to-day activities.

Thus, whilst the approach suggested by Hervey and Rostant is a step in the right direction, it is submitted that it requires further refinement for three primary reasons. First, the additional subsection proposed by Hervey and Rostant starts with the words, 'A person also has a disability'. This use of the word 'also' implies that this new subsection introduces an additional definition of disability into the Act, one that is concerned solely with societal barriers which hinder an individual's full and effective participation in society. The foreseeable consequence of this being that section 6(1) would be effectively concerned with purely physical barriers whilst section 6(2) would be concerned with purely societal barriers e.g. stigma. This presents problems for individuals whose impairments place them at a disadvantage due to both physical

[2016] UKEAT 0132_15_0102, [2016] IRLR 273.

The individual claimants in Paterson v Metropolitan Police Commissioner, Chief Constable of Dumfries and Galloway Constabulary $v$ Adams and Sobhi v Commissioner of Police of the Metropolis experienced, respectively, dyslexia, ME and dissociative amnesia.

T Hervey and P Rostant, “All About That Bass'? Is non-ideal-weight discrimination unlawful in the UK?' (2016) 79 (2) $248,275$. 
and societal barriers, for example an individual with symptomatic HIV. Such an individual may find themselves partially, but not fully, able to satisfy the definition in section 6(1) and partially, but not fully, able to satisfy the definition in section 6(2). A court or tribunal considering the sections in isolation could legitimately conclude that such an individual was not disabled even though the cumulative effect of their impairment could satisfy the definition of disability outlined in the United Nations CRPD upon which EU law heavily relies.

Second, the approach advocated by Hervey and Rostant fails to adequately reflect the approach advocated by the CJEU in Chacon Navas v Eurest Colectividades SA ${ }^{806}$ and HK Danmark (Ring and Skouboe Werge). ${ }^{807}$ Hervey and Rostant's approach defines disability as when an individual's impairment 'in interaction with any barriers placed by society, hinders his full and effective participation in society.' Whilst $H K$ Danmark uses the words 'which in interaction with various barriers may hinder the full and effective participation of the person' (emphasis added). The crucial absence of the word 'may' from Hervey and Rostant's definition suggests, contrary to the definition propounded by the CJEU, that a hindrance to the individual's full and effective participation in society is always required before an individual will meet the definition of disability. Yet as HK Danmark ${ }^{808}$ made clear disability 'does not necessarily imply complete exclusion from work or professional life, ${ }^{\prime} 80$ thus, it is logical that complete exclusion from society is also not necessary. Instead, as made clear by the CJEU, it is only necessary that an impairment may hinder an individual's full and effective participation for an individual to be classified as disabled.

Finally, it is submitted that two competing definitions of disability are unnecessary ${ }^{810}$ and indeed, that to adopt such an approach, goes against the inclusive nature of the definition employed by the United Nations CRPD. Disability is a complex concept, yet the United Nations CRPD combines and recognises the interaction between physical and societal barriers in its single definition. There is no reason why the EA 2010 should not also be able to do so. Taking all the above into account, it is proposed that the definition of section 6 be amended to read as follows:

(1) A person (P) has a disability if-

(a) P has a long-term physical or mental impairment, and

Case C-13/05 [2006] ECR I-6467.

Joined Cases C-335/11 and C-337/11, [2013] 3 CMLR 21.

For further discussion and analysis of HK Danmark see section 3.4.1.

Case C-13/05 [2006] ECR I-6467, [43].

These being Hervey and Rostant's proposed s 6(1) concerned with physical barriers and their proposed s 6(2) concerned with social barriers. 
(b) the impairment in interaction with various barriers may hinder P's full and effective participation in society including, but not limited to, the ability to carry out normal day-to-day activities.

Such an amendment to the EA 2010 it is hoped would ensure that PLHA can acquire protection from discrimination on the ground of disability. Indeed, in 2013 the German Federal Labour Court $^{811}$ decided that asymptomatic HIV infection can amount to a disability for the purposes of the German General Equal Treatment Act. The Federal Labour Court concentrated specifically on the inability of the individual to fully and effectively participate in society in reaching this decision stating:

The claimant is chronically ill due to his asymptomatic HIV infection. This impairment affects his participation both in life in the community and in his professional field. He is therefore disabled. This applies as long as the social avoidance behaviour currently attributable to such an infection and the stigmatisation based thereon persist. ${ }^{812}$ (translated from German original)

Reference was made by the Federal Labour Court to the jurisprudence of the CJEU, specifically the decision in HK Danmark (Ring and Skouboe Werge) ${ }^{813}$ and that the absence of any impact upon his functional performance was irrelevant to the question as to whether or not he was disabled, as:

The claimant is impaired by his HIV infection to the extent necessary to participate in life. It is irrelevant that his performance is not limited. It suffices that he may be exposed to stigmatisation in interpersonal relationships and at work. These prejudices and stigmatisation of his environment make him a disabled person. ${ }^{814}$ (translated from German original)

In this case, the fact that the claimant had sought to preserve his anonymity during the court proceedings and had failed to disclose his HIV status to his next employer was explicit evidence of the stigma that he was subject to. ${ }^{815}$ This acknowledgment by the Federal Labour Court of the stigma faced by PLHA represents an implicit use of the social model of disability. Indeed, it is submitted, it represents how PLHA can be adequately protected by a definition of disability in the EA 2010 which is grounded in the social model once the Deeming Provision is repealed.

Federal Labour Court Judgment of 19/12/2013, 6 AZR 190/12.

ibid [70].

Joined Cases C-335/11 and C-337/11, [2013] 3 CMLR 21.

Judgment of 19/12/2013, 6 AZR 190/12, [73].

ibid [75]. 
In light of the foregoing, it has been proposed that the wording of section 6 of the EA 2010 be amended in order to reflect the wishes of PLHA and also more accurately reflect the UK's obligations under both the CRPD and the Framework Directive. Making such an amendment will also more accurately reflect the fact that stigma is not a problem for all PLHA all of the time and instead acknowledge that stigma against PLHA operates in a socially differentiated manner. ${ }^{816}$ Thus, one of the key themes to emerge from the research was that the manner in which HIV impacts upon and stigmatises individuals is to a significant part governed by their own ethnicity and/or sexuality. ${ }^{817}$ By way of example, the experiences of those black Africans who participated in the research were markedly different to white participants. This was apparent even at the recruitment stage of the empirical research where it was noted that black Africans were much more difficult to recruit and also extremely reluctant to talk about their experiences of living with the virus. Further, those black Africans that did participate in the research had markedly different experiences to white participants in terms of stigma and discrimination. Black Africans overwhelmingly chose not to disclose their status for fear of discrimination and felt that there was a significant amount of hostility directed towards their community by certain sections of the media. ${ }^{818}$ Therefore, there was a clear difference in the disclosure experiences of Men who have sex with men (MSM), who were all white, and black Africans. As well as the difference in colour, the MSM in this survey often had highly remunerated, professional occupations which invariably gave them greater bargaining power in their employment relationships and made them feel more comfortable about disclosing. By contrast black Africans were much more cautious about disclosing possibly due to concerns about isolating themselves further from UK society because as R noted 'as a black African man, you feel like an outsider.' Black Africans also faced greater barriers in entering into the labour market in the UK as pre-existing professional qualifications were often not recognised by UK employers and/or their network of existing employment contacts from their former country of residence were of little use. The consequence of this was that black Africans often had to accept employment in lower paid, manual jobs where they were more vulnerable to discrimination due to the socio-economic differentiated manner in which HIV discrimination has been shown to operate. ${ }^{819}$

\subsection{THE CONDUCT WHICH PLHA ARE PROTECTED FROM: THE EQUALITY ACT'S FRAMEWORK OF PROHIBITED CONDUCT}

R Dray-Spira and others, 'Socioeconomic differences in the impact of HIV infection on workforce participation in France in the era of Highly Active Antiretroviral Therapy’ (2007) 97 (3) American Journal of Public Health 552. See section 6.2.2.

$818 \quad$ ibid.

819 R Dray-Spira and others, 'Socioeconomic differences in the impact of HIV infection on workforce participation in France in the era of Highly Active Antiretroviral Therapy’ (2007) 97 (3) American Journal of Public Health 552.
} 
Moving to the issue of whether the framework of prohibited conduct under the Equality Act represents an adequate response to the issues faced by PLHA and is consistent with both international and European legal obligations, two significant findings to emerge from the research was the fact that there were shortcomings concerning the Act's failure to prohibit multiple discrimination and its construction of the duty to make reasonable adjustments. These will now be considered in turn.

\subsubsection{MULTIPLE DISCRIMINATION}

Using the responses received by participants in the empirical research findings to critique the law from an external, non-doctrinal perspective, it is apparent that discrimination can no longer be defined in terms of solitary approaches, e.g. sexuality, race or disability alone. As illustrated by the responses from participants in section 6.2.2, the heightened stigma associated with HIV overlaps with various additional factors, e.g. intravenous drug use, sexuality, race, transmissibility and the current lack of cure. This stigma leaves PLHA vulnerable to discrimination on more than one ground. Thus, MSM may on occasion be discriminated against because of both their HIV status and their sexuality, ${ }^{820}$ whilst black Africans are at risk of discrimination because of their HIV status and their race. ${ }^{821}$

It is submitted that by analysing discrimination against PLHA from only one perspective, i.e. disability, the EA 2010 is flawed. Individuals invariably have more than one identity, for example within MSM a homosexual will not just perceive himself, or indeed be perceived by others, as homosexual, he may also be young, poorly educated, black and African. These identities coexist and interrelate with one another. The use of a solitary perspective also fails to recognise that identities are not static concepts and may alter both with time and the social setting or context in which the individual finds themselves. ${ }^{822}$ Intersectionality, a concept developed by Crenshaw ${ }^{823}$ and which has its roots in the feminist movement, means paying attention to how multiple social forces, such as race, class, gender, age, sexuality and culture, shape our experiences. ${ }^{824}$ It is clearly highly relevant to this area and could prove to be an

\footnotetext{
820 See the comments of $\mathrm{P}$ in section 6.4.6

$821 \quad$ See the comments of $\mathrm{L}$ in section 6.2

822 E Goffman, The Presentation of Self in Everyday Life (Penguin 1959).

Kimberle Crenshaw, 'Demarginalizing the Intersection of Race and Sex: A Black Feminist Critique of Antidiscrimination Doctrine, Feminist Theory and Antiracist Politics' [1989] University of Chicago Legal Forum, 139; Kimberle Crenshaw, 'Mapping the Margins: Intersectionality, Identity Politics, and Violence against Women of Color' (1991) 43 (6) Stanford Law Review 1241. 
effective tool in combating discrimination, yet the EA 2010's limited provision in relation to this concept appears at section $14 .^{825}$

From a normative perspective, as noted in section 4.3.2, section 14 of the EA 2010 termed 'combined discrimination' has not been brought into force. To remind the reader, section 14 states:

(1)A person (A) discriminates against another (B) if, because of a combination of two relevant protected characteristics, A treats B less favourably than A treats or would treat a person who does not share either of those characteristics.

(2)The relevant protected characteristics are-

(a) age;

(b) disability;

(c) gender reassignment;

(d) race

(e) religion or belief;

(f) sex;

(g) sexual orientation.

As this section is not in force under the current domestic legislative framework there is no formal protection for those who suffer discrimination because of a combination of protected characteristics as illustrated by Bahl v The Law Society. ${ }^{826}$ In Bahl, the initial Employment Tribunal found that Dr Bahl, an Asian woman appointed as deputy vice president of the Law Society, had been subjected to both direct race and direct sex discrimination without making an explicit distinction between the two. In coming to this conclusion the Employment Tribunal stated:

We do not distinguish between the race or sex of the applicant in reaching this conclusion. Our reason for that is simple. The claim was advanced on the basis that Kamlesh Bahl was treated in the way she was because she is a black woman. Kamlesh Bahl was the first office holder that the Law Society had ever had who was not both white and male. There was no basis in the evidence for comparing her treatment with that of a white female, or a black male, office holder. We can only draw inferences. 
We do not know what was in the minds of [the discriminators] at any particular point. It is sufficient for our purposes to find, where appropriate, that in each case they would not have treated a white person or a man less favourably. ${ }^{827}$

This decision was however overturned by both the Employment Appeal Tribunal and the Court of Appeal. For PLHA the problem of both Bahl and the EA 2010 is that they fail to acknowledge the vulnerability of PLHA to facing discrimination based on a combination of protected characteristics. The EA 2010's normative framework means that discrimination against a white male is the standard disability discrimination claim. ${ }^{828}$ Therefore, if a black HIV positive employee claims direct disability and race discrimination, they must point to evidence from which it can be inferred that the less favourable treatment was on the ground of disability and (separately) on the ground of race. ${ }^{829}$ If discrimination cannot be found on either ground considered independently of each other, their case will not succeed. ${ }^{830}$ Crenshaw asserts that 'claims that diverge from this standard appear to present some sort of hybrid claim' which can be contrasted in this case with 'pure' claims of disability discrimination. ${ }^{831}$

This failure to prohibit discrimination based upon more than one protected characteristic and bring section 14 of the EA 2010 into force is a clear failure to fully implement Article 6 of the United Nations CRPD. ${ }^{832}$ Thus Article 6(1) provides:

States Parties recognise that women and girls with disabilities are subject to multiple discrimination, and in this regard shall take measures to ensure the full and equal enjoyment by them of all human rights and fundamental freedoms.

The failure to implement Article 6 was a matter specifically raised by the United Nations Committee on the Rights of Persons with Disabilities in their concluding observations on the initial report of the UK. The Committee was 'concerned that the State party's antidiscrimination legislation does not provide comprehensive and appropriate protection,

ibid, [135].

S Fredman, 'Equality: A New Generation' (2001) 30 (2) Industrial Law Journal 30(2) 145.

S136 Equality Act 2010.

There is authority to suggest however that Tribunals are possibly more amenable to claim of multiple indirect discrimination. In Ministry of Defence v Debique [2009] UKEAT 0048_09_1210, [2010] IRLR 471 the Employment Appeal Tribunal upheld an indirect discrimination claim based on two characteristics where neither by itself was sufficient to found a claim. In the Employment Appeal Tribunal, at [65], Mrs Justice Cox stated that discrimination 'was a multifaceted experience' which could not always be sensibly compartmentalised into discrete categories.

Kimberle Crenshaw, 'Demarginalizing the Intersection of Race and Sex: A Black Feminist Critique of Antidiscrimination Doctrine, Feminist Theory and Antiracist Politics' [1989] University of Chicago Legal Forum, 139, 145 .

See section 3.2.5 for discussion of Article 6 of the United Nations CRPD. 
particularly against multiple and intersectional discrimination'. ${ }^{833}$ Specifically with regard to women, the Committee was 'concerned at the lack of measures and available data concerning the impact of multiple and intersectional discrimination against women and girls with disabilities. ${ }^{834}$ These concerns led them to recommend:

[T] hat the State party...explicitly incorporate in its national legislation protection from multiple and intersectional discrimination on the basis of gender, age, race, disability, migrant, refugee and/or other status, and provide appropriate compensation and redress for victims, and sanctions proportional with the severity of the violation. ${ }^{835}$

In addition, the UN Committee on the Rights of Persons with Disabilities General Comment 6 has recently reemphasised that in the context of work and employment States Parties should prohibit multiple and intersectional discrimination. ${ }^{836}$ It is also noteworthy that the Framework Directive recognises multiple discrimination at Recital 3 noting that:

In implementing the principle of equal treatment, the Community should, in accordance with Article 3(2) of the EC Treaty, aim to eliminate inequalities, and to promote equality between men and women, especially since women are often the victims of multiple discrimination.

Multiple discrimination is also recognised in a similar form in the Racial Equality Directive ${ }^{837}$ at Recital 14.838

Yet when compared to international and European normative sources, it is clear that section 14 of the EA 2010 fails to comply with the expected standards. Indeed, even if it were to be brought into force in its current form, section 14 remains non-compliant with Article 6 of the United Nations CRPD as it only prohibits direct discrimination based on a combination of two relevant

UN Committee on the Rights of Persons with Disabilities, Concluding Observations to Concluding observations on the initial report of the United Kingdom of Great Britain and Northern Ireland, adopted at the 365th session (29 August 2017), UN Doc. CRPD/C/GBR/CO/1 available at <http://tbinternet.ohchr.org/_layouts/treatybodyexternal/Download.aspx?symbolno=CRPD $\% 2 \mathrm{fC} \% 2 \mathrm{fGBR} \% 2 \mathrm{fCO} \% 2 \mathrm{f}$ 1\&Lang=en> accessed 18 December 2017, [14].

UN Committee on the Rights of Persons with Disabilities, General Comment No. 6 on equality and non-discrimination, adopted at the nineteenth session of the Committee (14 February-9 March 2018) on 9 March 2018, UN Doc. CRPD/C/GC/6, para. 67. irrespective of racial or ethnic origin [2000] OJ L 180/22. 
protected characteristics. This highly restricts the application of section 14 to many PLHA. By way of example, gay men who are HIV positive tend to be subjected to a particular and aggressive form of stigma. Indeed, they are incorrectly perceived as promiscuous and responsible for the spread of the virus in a manner in which lesbians who are HIV positive are not. This can be seen from M's comments in Chapter 6:

That "M" was, you know, having coke-fuelled orgies on a Saturday night with 200 men or something like that. Well I'm pretty sure that's where my mum's head goes every time. And I know that a lot of people hold that view, and I see that amongst my friends, and I have to challenge them.

M, 23 year old, Man who has had sex with men

Thus, it is apparent that there are two distinct characteristics at play that contribute to this unique form of discrimination. First, the individual's sexuality and second, their HIV status. If such an individual were also a member of an ethnic minority and were, for example, told that they should go home to prevent the spread of AIDS then a third factor comes into play, race. Yet section 14 only allows two protected characteristics to be taken into account.

In addition, it is also apparent that the greater the number of grounds an individual seeks to claim protection under, the further they stray from the 'norm'. Society is still unable to fully accept such individuals and thus, even after the passage of the EA 2010, Fredman's assertion that the dominant white, male cultural model is the norm still holds true. ${ }^{839}$ Indeed, one question which merits further research is the extent to which, if at all, black African women experience additional discrimination as opposed to black African men or white women.

An additional example of section 14's non-compliance with international and European normative sources is the fact that section 14(2) restricts those protected characteristics that may be combined to present a claim. As the protected characteristics of marriage, civil partnership and pregnancy and maternity are not included, the fact that women and girls are often subjected to multiple discrimination is, therefore, disregarded by section 14 which is contrary to the CRPD.

In light of the above, section 14 of the EA 2010 should be amended as follows:

(1) A person (A) discriminates against another (B) if, because of a combination of two or more relevant protected characteristics, A treats B less favourably than A treats or would treat a person who does not share either of those characteristics. 
Section 14(2), which restricts the list of protected characteristics capable of being combined to advance a claim, should be deleted.

\subsubsection{REASONABLE ADJUSTMENTS}

From a normative perspective, as a consequence of Schedule 8, paragraph 20(1)(a) of the EA 2010, an employer only has a duty to make an adjustment if they know, or could reasonably be expected to know, that a worker has a disability and is, or is likely to be, placed at a substantial disadvantage. Although the EA 2010 does not prevent a disabled individual keeping their condition confidential, the significance is the employer will not be under a duty to make a reasonable adjustment if they lack the requisite knowledge. As noted in section 4.3.8, there is no requirement of substantial disadvantage for the duty to arise under the CRPD, which means that the duty has not been correctly implemented into domestic law.

As discussed in section 3.4.2 both the United Nations CRPD and the Framework Directive contain no information as to what knowledge of an individual's disability an employer must have before the duty to make a reasonable accommodation arises. However, Ferri and Lawson consider that the approach taken by the UK is consistent with the CRPD. ${ }^{840}$ Despite this, in their concluding observations on the initial report of the UK, the United Nations Committee on the Rights of Persons with Disabilities expressed concern about:

The insufficient measures of affirmative actions and provision of reasonable accommodation improving the possibility of employment for persons with disabilities on the open labour market, despite the obligations contained in the European Union Directive 2000/78/EC on non-discrimination in the work place. ${ }^{841}$

Indeed, the provision of reasonable adjustments for PLHA remains problematic due to the requirement that an employer has either actual or constructive knowledge of an individual's disability. As HIV is by its very nature invisible to the naked eye, it is obviously more difficult for an employer to acquire constructive knowledge than for an individual with a disability with visible characteristics. This requirement places PLHA in somewhat of a dilemma. Either they keep their diagnosis private and attempt to remain in employment without the benefit of

Delia Ferri and Anna Lawson, 'Reasonable accommodation for disabled people in employment' (Directorate-General for Justice and Consumers 2016), 67.

UN Committee on the Rights of Persons with Disabilities, Concluding Observations to Concluding observations on the initial report of the United Kingdom of Great Britain and Northern Ireland, adopted at the 365th session (29 August 2017), UN Doc. CRPD/C/GBR/CO/1 available at < http://tbinternet.ohchr.org/_layouts/treatybodyexternal/Download.aspx?symbolno=CRPD $\% 2 \mathrm{fC} \% 2 \mathrm{fGBR} \% 2 \mathrm{fCO} \% 2 \mathrm{f} 1$ \&Lang=en $>$ accessed 18 December 2017, [56(b)]. 
reasonable adjustments or they disclose to their employer but risk being subjected to stigma, discrimination and potentially, the termination of their employment. The empirical data revealed that whilst some participants were very open about their HIV status and had disclosed their status to their employer, others viewed their HIV status as being a private matter and something which had no bearing whatsoever on their ability to do their job. A number of participants expressed concern that the manner in which the concept of reasonable adjustments was framed under the EA 2010 could place pressure on PLHA to disclose their status. This illustrates the inadequacies of the current normative framework.

In order to overcome these difficulties, it is submitted that a purposive interpretation of the United Nations CRPD and, in turn, the EA 2010 would assist. In the United Nations CRPD, reasonable accommodation is defined in Article 2 as 'necessary and appropriate modification and adjustments not imposing a disproportionate or undue burden, where needed in a particular case, to ensure to persons with disabilities the enjoyment or exercise on an equal basis with others of all human rights and fundamental freedoms' ${ }^{842}$ It is submitted, however, that Article 2 must be read in conjunction with the CRPD's use of the social model of disability, which emphasises the removal of societal barriers, including attitudinal barriers. Given the significant amount of stigma directed towards individuals with disabilities in the current age of austerity, ${ }^{843}$ it is clear that more must be done to reduce stigma towards all individuals with disabilities within the workplace which should in turn benefit PLHA.

Indeed, in the concluding observations of the initial report of the UK by the United Nations Committee on the Rights of Persons with Disabilities, it was stated that the UK must:

Ensure that reasonable accommodation is provided to all persons with disabilities who require it in the workplace, that regular training on reasonable accommodation is available to employers and employees without disabilities, and that dissuasive and effective sanctions are in place in cases of denial of reasonable accommodation. ${ }^{844}$

Of note here is the fact that the United Nations Committee on the Rights of Persons with Disabilities recommended that the UK must ensure that 'regular training on reasonable accommodation is available to employers and employees without disabilities' (emphasis added).

Article 2 United Nations CRPD.

Emma Briant, Nick Watson and Gregory Philo, 'Reporting disability in the age of austerity: the changing face of media representation of disability and disabled people in the United Kingdom and the creation of new folk devils' (2013) 28 (6) Disability and Society 874.

UN Committee on the Rights of Persons with Disabilities, Concluding Observations to Concluding observations on the initial report of the United Kingdom of Great Britain and Northern Ireland, adopted at the 365th session (29 August 2017), UN Doc. CRPD/C/GBR/CO/1 available at < http://tbinternet.ohchr.org/_layouts/treatybodyexternal/Download.aspx?symbolno=CRPD $\% 2 \mathrm{fC} \% 2 \mathrm{fGBR} \% 2 \mathrm{fCO} \% 2 \mathrm{f} 1$ \&Lang=en> accessed 18 December 2017, [57(b)]. 
Significantly, no mention is made of training being provided to employees with disabilities. This wording could therefore indicate that, for the purposes of the CRPD, the Committee is open to a duty being placed on employers to implement necessary and appropriate adjustments to remove societal, as opposed to physical, barriers towards employees with disabilities without the need for a specific request from an individual with a disability.

Such an interpretation would also accord with Article 27(1)(i) of the CRPD, which relates specifically to work and employment and provides that State Parties must "[e]nsure that reasonable accommodation is provided to persons with disabilities in the workplace" ${ }^{845}$ The use of the word 'ensure' in Article 27 goes further than the approach adopted by the EA 2010 and confirms that the focus on the CRPD is on the need for reasonable accommodation to be provided to persons with disabilities and without any restriction placed on such provision, e.g. by means of a specific request from an individual with a disability being required. The removal of societal barriers in the workforce would also accord with Article 27(1) which states, inter alia, that 'States Parties recognise the right of persons with disabilities to work, on an equal basis with others; this includes the right to the opportunity to gain a living by work freely chosen or accepted in a labour market and work environment that is open, inclusive and accessible to persons with disabilities' (emphasis added). It would also accord with the overall objective of the CRPD, which is 'to promote, protect and ensure the full and equal enjoyment of all human rights and fundamental freedoms by all persons with disabilities, and to promote respect for their inherent dignity' (emphasis added). ${ }^{846}$ Finally, the approach would accord with General Comment 6 of the UN Committee on the Rights of Persons with Disabilities which states that States Parties should '[p]romote work in inclusive and accessible, safe and healthy working environments in the public and private sectors' (emphasis added) ${ }^{847}$

Returning specifically to the EA 2010, in non-employment areas (other than premises) ${ }^{848}$ the duty imposed by section 20 to make reasonable adjustments is anticipatory in nature as opposed to reactive. For example, service providers are required to monitor the services or functions they provide on an ongoing basis in order to anticipate any potential disadvantage which may be caused to disabled individuals by their provisions, criteria or practices, by their physical features, or by their auxiliary aid or service provision. ${ }^{849}$ If any disadvantage can be anticipated, service providers are required to take reasonable steps to remove the disadvantage even if nobody has actually yet been disadvantaged. The duties do also have a reactive element as

See section 3.2.5 for discussion of the duty of reasonable accommodation under the United Nations CRPD.

Article 1 United Nations CRPD.

UN Committee on the Rights of Persons with Disabilities, General Comment No. 6 on equality and non-discrimination, adopted at the ninetenth session of the Committee (14 February-9 March 2018) on 9 March 2018, UN Doc. CRPD/C/GC/6, para. 67.

Premises are exempted from the anticipatory duty by Schedule 4 of the Equality Act 2010.

Sch 3, para 2 Equality Act 2010.
} 
service providers are required to take reasonable steps to remove a disadvantage once they become aware that a disabled individual is being disadvantaged in accessing their services. Lawson argues that these anticipatory duties have a much greater potential to drive systemic change than the present reactive employment duty. ${ }^{850}$ The use of a reactive duty within employment has the potential to improve access to, and opportunities within, employment not only for PLHA but all individuals with disabilities and break the current uneasy truce which is of questionable benefit to employers and employees. A reactive duty would particularly benefit PLHA by reducing the emphasis placed on disclosure in obtaining reasonable adjustments in employment relationships. In addition, in relation to work and employment, as stated above, the focus of Article 27 of the CRPD is on adjustments being provided to persons with disabilities without the need for any specific request from an individual with a disability being required. This strongly suggests that the use of a reactive duty to make reasonable adjustments is required within the area of employment.

To implement these proposals, and better reflect the fact that the CRPD arguably imposes a duty upon employers to remove disadvantages, the wording of specific subsections of section 20(4) of the EA 2010 ought to be amended as follows in order to more closely align with the United Nations CRPD and its use of the social model of disability:

(4) The second requirement is a requirement, where a physical or societal feature puts or would put a disabled person at a disadvantage in relation to a relevant matter in comparison with persons who are not disabled, to take such steps as it is reasonable to have to take to avoid the disadvantage. (emphasis added).

Clearly, the requirement that an employer only has a duty to make an adjustment if they know, or could reasonably be expected to know, that a worker has a disability, contained in Schedule 8, paragraph 20(1)(a) of the EA 2010, should be repealed.

\subsection{STIGMA}

The final issue to be addressed by this conclusion is the overarching issue of stigma. The stigma associated with HIV/AIDS is still considerable in many sectors of society. Indeed, it became apparent from the doctrinal and empirical research that more ought to be done to combat stereotypes and prejudice directed towards PLHA. Stigma gradually erodes the dignity of PLHA as evidenced by the comment of one participant in the interviews conducted. He stated, 'you don't want to, to embody yourself as [having] HIV and AIDS, you're diseased, you're filthy, 
you're about to die. ${ }^{851}$ Yet the concept of dignity is central to the CRPD; indeed, the preamble recalls, 'the principles proclaimed in the Charter of the United Nations which recognise the inherent dignity and worth and the equal and inalienable rights of all members of the human family as the foundation of freedom, justice and peace in the world' ${ }^{852}$ Whilst Article 1 outlines that the purpose of the Convention is to 'promote, protect and ensure the full and equal enjoyment of all human rights and fundamental freedoms by all persons with disabilities, and to promote respect for their inherent dignity. ${ }^{853}$

More recently in General Comment 6 the UN Committee on the Rights of Persons with Disabilities has reiterated that, 'Equality and non-discrimination are among the most fundamental principles and rights of international human rights law. Because they are interconnected with human dignity, they are the cornerstones of all human rights. ${ }^{854}$ Indeed, the Committee noted that "The term "dignity" appears in the Convention more often than in any other United Nations human rights convention. ${ }^{855}$

Although academics, such as McConnachie, have argued that the concept of dignity lacks sufficient precision to be used as a legal principle in deciding cases involving discrimination, the term itself is worthy of attention not least because it recognises the inherent self-worth of all individuals. ${ }^{856}$ Human dignity 'means that an individual or group feels self-respect and selfworth. It is concerned with physical and psychological integrity and empowerment' and 'is harmed by unfair treatment premised upon personal traits or circumstances which do not relate to individual needs, capacities, or merits. ${ }^{957}$ Ignorance amongst the judiciary regarding PLHA, as evidenced by the dicta in High Quality Lifestyles Ltd $v$ Watts, ${ }^{858}$ and the shameful comments a number of the participants to this research were subjected to by work associates inevitably erode the dignity of PLHA.

Yet there are limits to what any doctrinal framework can do in isolation from other societal factors. Consequently, a new education campaign is required to combat stigma associated with PLHA in order to preserve the dignity of PLHA and remove the barriers created by stigma that

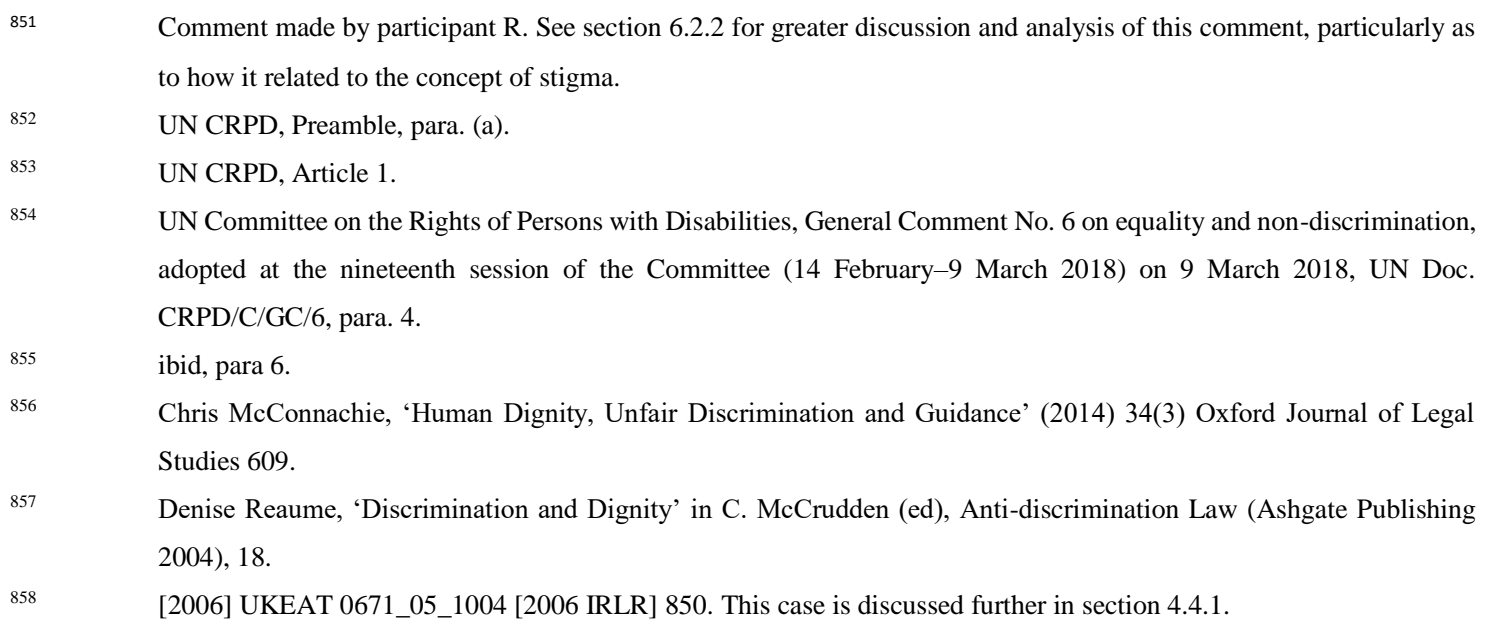
Comment made by participant R. See section 6.2 .2 for greater discussion and analysis of this comment, particularly as to how it related to the concept of stigma.

$852 \quad$ UN CRPD, Preamble, para. (a).

853 UN CRPD, Article 1.

854 UN Committee on the Rights of Persons with Disabilities, General Comment No. 6 on equality and non-discrimination, adopted at the nineteenth session of the Committee (14 February-9 March 2018) on 9 March 2018, UN Doc. CRPD/C/GC/6, para. 4. ibid, para 6. Chris McConnachie, 'Human Dignity, Unfair Discrimination and Guidance' (2014) 34(3) Oxford Journal of Legal Studies 609 . 
prevent society being truly accessible and inclusive towards many PLHA. The fact that the UK needs to do more to combat prejudice directed towards individuals was specifically raised by the UN Committee on the Rights of Persons with Disabilities in the Concluding Observations of their initial report of the UK. The Committee was 'concerned at the persistence of negative attitudes, stereotypes and prejudice against persons with disabilities ${ }^{859}$ and recommended that the UK, 'in close collaboration with organisations of persons with disabilities, strengthen its awareness-raising campaigns aimed at eliminating negative stereotypes and prejudice towards persons with disabilities' ${ }^{860}$ The use of such a campaign to tackle misconceptions and stereotypes surrounding HIV could assist significantly in reducing stigma towards PLHA and enabling PLHA to participate fully and effective in society on an equal basis with others

\subsection{CONTRIBUTION TO EXISTING LEGAL SCHOLARSHIP}

This final section will address the original contribution that this work makes to existing legal scholarship.

This thesis addressed a question that has not been the subject of any earlier doctrinal or empirical research, which is whether the approach taken by the Equality Act 2010, and more specifically its decision to deem PLHA as disabled from the point of their diagnosis, adequately protects PLHA within an employment relationship. ${ }^{861}$ In addition to answering this question, the thesis makes a number of recommendations to ensure that the UK's approach accords with both the experiences and wishes of PLHA, and the UK's international and European legal obligations. The thesis also yields a significant amount of original, rich, empirical data into PLHA's awareness of, and interaction with, the EA 2010 in addition to their experiences of employment.

What legal scholarship there is into PLHA within employment relationships primarily originates from outside the UK and consequently the findings of such research, whilst of relevance, are questionable due to the differing normative rules, socio-economic standards and welfare systems of different jurisdictions. The only piece of empirical research that has specifically examined the employment experiences of people living with HIV in the UK was a study by Douglas in 2009. 862 Yet Douglas's study only undertook empirical research into the experiences

UN Committee on the Rights of Persons with Disabilities, Concluding Observations to Concluding observations on the initial report of the United Kingdom of Great Britain and Northern Ireland, adopted at the 365th session (29 August 2017), UN Doc. CRPD/C/GBR/CO/1 available at <http://tbinternet.ohchr.org/_layouts/treatybodyexternal/Download.aspx?symbolno=CRPD $\% 2 \mathrm{fC} \% 2 \mathrm{fGBR} \% 2 \mathrm{fCO} \% 2 \mathrm{f}$ 1\&Lang=en> accessed 3 May 2018, para 22 ibid, para 23 Equality Act 2010, sch 1 para 6.

N. Douglas, 'I just get on with it...A study of the employment experiences of gay and bisexual men and black African men and women living with HIV in the UK' (National AIDS Trust 2009). 
of MSM and heterosexual black Africans and, as it was not a piece of legal research, contained no analysis of the relevant normative sources. By contrast, for the purposes of this work, empirical research was undertaken into the experiences of non-black African heterosexuals in addition to heterosexual black Africans and MSM. Furthermore, the relevant international, European and domestic normative sources were identified, discussed and analysed both from a doctrinal and empirical perspective.

By addressing the deficiencies with the designation of PLHA as disabled by the EA 2010 and critiquing the legal framework law from both a traditional doctrinal perspective and external, non-doctrinal perspective, this thesis makes an original contribution to existing legal scholarship and literature concerning discrimination. By employing a methodological approach, the work was able to use the findings of the empirical research to augment the critique and analysis of the normative legal framework. It used the voices of PLHA to aid a critique of the legal framework to which they are subject and, in doing so, respects one of the central tenets of the disability rights movement - nothing about us without us. ${ }^{863}$ By using the voices of PLHA in this manner, it illustrated the importance of ensuring that legislation takes into account the issues affecting those it is designed to protect. Of note, is the fact that the Deeming Provision also deems individuals with Cancer or MS to be disabled. Further research and analysis is required in order to clarify whether individuals with Cancer or MS perceive themselves as disabled or whether they too would rather not be included within the scope of the Deeming Provision. Unfortunately this was not within the remit of this work and so it is left for a further research project.

In part, this work has specifically considered the question of disability and the interplay between domestic legislation; international and European obligations; and theoretical models of disability. In doing so, it illustrates the importance of ensuring that domestic legislation accords with relevant non-legal theoretical models within the relevant field of legal study. This is especially important when domestic laws based upon one theoretical model need to accord with a superior source of law which may be grounded in a different theoretical model. In utilising this approach, this work offers an academic framework that research into other legal specialities may wish to employ. Thus, by way of example, research into urban air pollution and environmental protection law may wish to ensure relevant legislation accords not only with germane non-domestic legal obligations but also the theoretical models of environmental protection employed at both the domestic and non-domestic level. ${ }^{864}$ Similarly research into personal insolvency may take into account relevant models relating to consumer bankruptcy. ${ }^{865}$

James Charlton, Nothing About Us Without Us (University of California Press 2000).

See for example Michael Jerrett and others, 'A review and evaluation of intraurban air pollution exposure models' (2005) 15 Journal of Exposure Analysis and Environmental Epidemiology 185.

See for example Iain Ramsay, 'Models of Consumer Bankruptcy: Implications for Research and Policy' (1997) 20 Journal of Consumer Policy 269. 
The use of such an approach to legal research enables the normative legal framework in question to be examined from an additional perspective, presenting the researcher with additional data which both aids analysis of the normative legal framework and ensures that the law takes into account the relevant social and theoretical framework within which it operates. 


\section{BIBLIOGRAPHY}

\section{TABLE OF CASES}

\section{$\underline{\text { UK CASES }}$}

A v SSHD (No. 2) [2005] UKHL 71; [2006] 2 AC 221

AH v West London MHT [2011] UKUT 74, [2011] AACR 15

Abadeh v British Telecommunications plc [2001] IRLR 23

Aitken v Commissioner of Police of the Metropolis [2011] EWCA Civ 582, [2012] I.C.R. 78

Akerman-Livingstone v Aster Communities Limited [2015] UKSC 15, [2015] AC 1399

Al Jumard v Clywd Leisure Ltd and Others [2008] UKEAT/0334/07/ZT, [2008] I.R.L.R. 345

Archibald v Fife Council [2004] UKHL 32, [2004] 4 All E.R. 303

Assange v Swedish Prosecution Authority (Nos 1 and 2) [2012] UKSC 22; [2012] 2 AC 471

Aylott v Stockton on Tees Borough Council [2010] EWCA Civ 910, [2010] IRLR 994

Bahl v The Law Society [2004] EWCA Civ 1070, [2004] IRLR 799

Banaszczyk v Booker Ltd. [2016] UKEAT 0132_15_0102, [2016] IRLR 273

British Airways plc v Starmer [2005] UKEAT 0306_05_0607, [2005] IRLR 86

British Midland Airways Ltd v Hamed [2010] UKEAT 0292_10_0311

British Telecommunications plc v Sheridan [1990] IRLR 27 (CA)

Buck v Letchworth Palace Ltd. [1986] 36488/86 (ET)

Burnip v Birmingham City Council [2012] EWCA Civ 629, [2012] Eq LR 70

Carranza v General Dynamics Information Technology Ltd [2014] UKEAT 0107_14_1010, [2015] IRLR 43

Chief Constable of Dumfries and Galloway Constabulary v Adams [2009] UKEAT

0046_08_0304, [2009] IRLR 612

Chief Constable of Norfolk v Coffey [2017] UKEAT 0260_16_1912, [2018] I.R.L.R. 193

City of York Council v Grosset [2018] EWCA Civ 1105

Clark v TDG trading as Novacold [1999] ICR 951 (CA)

Cordell v Foreign and Commonwealth Office [2011] UKEAT 0016_11_0510, [2012] ICR 280

Cosgrove v Northern Ireland Ambulance Service [2006] NICA 44, [2007] IRLR 397

EBR Attridge LLP (formerly Attridge Law) and another v Coleman UKEAT/0071/09/JOJ, [2010] ICR 242 
Factortame v Secretary of State for Transport (No 2) [1991] 1 AC 603 (HL)

Gallop v Newport City Council [2013] EWCA Civ 1583; [2014] I.R.L.R. 211

Garland v British Rail Engineering Ltd [1983] 2 AC 751 (HL)

Ghaidan v Godin-Mendoza [2004] UKHL 30, [2004] 2 AC 557

Glasgow City Council v Zafar [1997] 1 W.L.R. 1659 (HL)

Hainsworth v Ministry of Defence [2014] EWCA Civ 763, [2014] IRLR 728

Hereford and Worcester County Council v Neale [1986] IRLR 168 (CA)

Hewage v Grampian Health Board [2012] UKSC 37; [2012] 4 All ER 447

High Quality Lifestyles Ltd v Watts [2006] UKEAT 0671_05_1004, [2006] I.R.L.R. 850

Hospice of St Mary of Furness v Howard [2007] UKEAT 0646_06_1805, [2007] IRLR 944

Jessemey v Rowstock Ltd \& Davis [2014] EWCA Civ 185, [2014] WLR 3615

J H Rayner (Mincing Lane) Ltd v Department of Trade and Industry [1990] 2 AC 418

London Borough of Lewisham v Malcolm [2008] UKHL 43, [2008] 1 A.C. 1399

McCubbin v Perth \& Kinross Council UKEATS/0025/13

Mahon v Accuread Ltd UKEAT/0081/08, [2008] All ER (D) 217

Melon v Hector Powe Ltd [1980] IRLR 477 (CA)

MacCulloch v ICI [2008] UKEAT 0119_08_2207, [2008] IRLR 846

Ministry of Defence v Debique [2009] UKEAT 0048_09_1210, [2010] IRLR 471

Mowat-Brown v University of Surrey [2002] IRLR 235

Newham Sixth Form College v Sanders [2014] EWCA Civ 734, [2014] All ER (D) 87

Nwoke v Government Legal Service and Civil Service Commissioners (1996) 28 Equal Opportunities Review 6

O'Neill v Governors of St Thomas More Roman Catholic Voluntary Aided Upper School and anor. [1997] ICR 33

Paterson v Metropolitan Police Commissioner [2007] UKEAT 0635_06_2307, [2007] IRLR 763

Polkey v A.E. Dayton Ltd [1988] A.C. 344

R (Aspinall) v The Secretary of State for Work and Pensions [2014] EWHC 4134 (Admin).

R (Davey) v Oxfordshire County Council [2017] EWHC 354,[2017] WLR(D) 590

R (Davey) v Oxfordshire County Council [2017] EWCA Civ 1308; (2017) 20 C.C.L. Rep. 303

R (Elias) v Secretary of State for Defence [2006] EWCA Civ 1293, [2006] IRLR 934 
R (MA) v The Secretary of State for Work and Pensions [2013] EWHC 2213; [2013] P.T.S.R. 1521

$\mathrm{R}$ (On the application of E) v Governing Body of JFS and others [2009] UKSC 15, [2010] 2 A.C. 728

Revenue and Customs Commissioners v IDT Card Services Ireland Ltd [2006] EWCA Civ 29, [2006] STC 1252

J H Rayner (Mincing Lane) Ltd v Department of Trade and Industry [1990] 2 AC 418 (HL)

Jhuti v Royal Mail Group [2017] UKEAT 0062_17_3107, [2017] WLR(D) 613

Saunders v Scottish National Camps Association Ltd [1980] IRLR 174 (CSIH)

Secretary of State for the Department for Work and Pensions v Alam [2009] UKEAT

0242_09_0911, [2010] ICR 665

Southampton City College v Randall [2005] UKEAT 0372_05_0711, [2006] IRLR 18

Thoburn v Sunderland County Council [2002] EWHC 195, [2003] QB 151

Thompson v London Central Bus Co [2016] IRLR 9

X v Y [2003] UKEAT 0765_02_1106, [2003] I.C.R. 1138

X v Mid Sussex Citizens Advice Bureau [2012] UKSC 59, [2013] 1 All E.R. 1038

\section{EUROPEAN UNION CASES}

Algemene Transporten Expeditie Onderneming van Gend en Loos NV v Nederlandse Belastingadministratie (C-26/62) [1963] ECR 1

Bilka-Kaufhaus GmbH v Weber von Hartz (C-170/84) [1986] ECR 1607

Becker v Finanzamt Munster-Innenstadt (C-8/81) [1982] ECR 53

Chacon Navas v Eurest Colectividades SA (C-13/05) [2006] ECR I-6467

CHEZ Razpredelenie Bulgaria AD v Kosimia za Zashtita ot Diskriminatsia (C-83/14) [2016] 1 CMLR 491

Coleman v Attridge Law (C-303/06) [2008] ECR I-05603

Coote v Granada Hospitality Ltd (C-185/97) [1998] ECR I-5199

Costa v ENEL (C-6/64) [1964] ECR 585

Fag og Arbejde v. Municipality of Billund (C-354/13) [2015] 2 CMLR 19

Farrell v Whitty (C-413/15) [2018] 1 C.M.L.R. 46

Foster and others v British Gas (C-188/89) [1990] ECR I-3313

Francovich v Italy (C-6/90) [1991] ECR-I 5357 
Fratelli Constanzo SpA v. Commune di Milano (C-103/88) [1989] E.C.R. 1839

HK Danmark, acting on behalf of Jette Ring v. Dansk Almenyttigt Boligselskab DAB and HK Danmark, acting on behalf of Lone Skoube Werge v. Pro Display A/S in liquidation (C335/11 and C-337/11) [2013] 3 CMLR 21

Johnston v. Chief Constable of the Royal Ulster Constabulary (C-222/84) [1986] E.C.R. 1651

Marleasing SA v La Comercial Internacional de Alimentacion SA (C-106/89) [1990] ECR I4135

Marshall v Southampton and South-West Hampshire Area Health Authority (Teaching) (C152/84) [1986] ECR 723

Merck \& Co. Inc., Merck Sharp \& Dohme Ltd and Merck Sharp \& Dohme International Services BV v Primecrown Ltd, Ketan Himatlal Mehta, Bharat Himatlal Mehta and Necessity Supplies Ltd and Beecham Group plc v Europharm of Worthing Ltd. (C-267/95 and C268/95) [1996] ECR-I-06285

Milkova v Izpalnitelen director na Agentsiata za privatizatsai I sledprivatizatsioen control (C406/15) EU:C:2017:198

Navas v Eurest Colectividades SA (C-13/05) [2006] ECR I-06467

Pfeiffer v Deustsches Rotes Kreuz, Kreisverband Waldshut eV (C-397/01) [2004] ECR I-8835

Wagner Miret v Fondo de Garantia Salarial (C-334/92) [1993] ECR I-6911

Wünsche Handelsgesellschaft GmbH \& Co. v Federal Republic of Germany, a judgment of the CJEU in a preliminary reference procedure is binding only on the national court that submitted the question (C-69/85) [1986] ECR 947

$\mathrm{Z} v$ A Government department and The Board of management of a community school (C-363/12) [2014] 3 CMLR 20

\section{EUROPEAN COURT OF HUMAN RIGHTS CASES}

Bărbulescu v. Romania App no 61496/08 (5 September 2017)

Eweida v the United Kingdom [2013] ECHR 285

Glor v. Switzerland 2009-III 33

Gubernia v Croatia App no 23682/13 (22 March 2016)

I.B. v. Greece, Application no. 552/10 (3 October 2013)

Kiss v Hungary App no 38832/06 (20 May 2010)

Kiyutin v. Russia App no 2700/10 (10 March 2011)

Marckx v Belgium (1979) 2 EHRR 330

Petrovic v Austria (2001) 33 EHRR 14

Pretty v. United Kingdom (2002) 35 EHRR 1

Redfearn v United Kingdom [2012] ECHR 1878 
Smith and Grady v United Kingdom (2001) 31 EHRR 24

Van der Mussele v Belgium (1983) 6 EHRR 163

\section{UNITED STATES CASES}

Bragdon v. Abbott (1998) 524 U.S. 624

Griggs v Duke Power Company (1971) 401 U.S. 424

\section{GERMAN CASES}

German Federal Labour Court judgment of 19/12/2013, 6 AZR 190/12 


\section{LEGISLATION}

\section{UK LEGISLATION}

The Disabled Persons (Employment) Act 1944

European Communities Act 1972

Sex Discrimination Act 1975

Race Relations Act 1976

Employment Protection (Consolidation) Act 1978

Disability Discrimination Act 1995

Employment Rights Act 1996

Human Rights Act 1998

Freedom of Information Act 2000

The European Communities (Definition of Treaties) (UN CRPD) Order, SI 2009/1181

Equality Act 2010

Equality Act (Disability) Regulations 2010, SI 2010/2128

$\underline{\text { IRISH LEGISLATION }}$

Maternity Protection Act 1994

Adoptive Leave Act 1995

\section{US LEGISLATION}

Civil Rights Act 1964

Americans with Disabilities Act 1990

\section{POLISH LEGISLATION}

Act of 27 August 1997 on vocational and social rehabilitation and employment of disabled persons

\section{SPANISH LEGISLATION}

Royal Legislative Decree 1/2013, of November 29, approving the Consolidated Text of the General Law on the rights of persons with disabilities and their social inclusion

\section{EUROPEAN UNION LEGISLATION}

Charter of Fundamental Rights of the European Union (2000) OJ C 364/01.

Council Directive 2000/78/EC of 27 November 2000 establishing a general framework for equal treatment in employment and occupation [2000] OJ L 303/16 
Council Directive 2000/43/EC of 29 June 2000 implementing the principle of equal treatment between persons irrespective of racial or ethnic origin [2000] OJ L 180/22.

Council Directive 2004/113/EC of 13 December 2004 implementing the principle of equal treatment between men and women in the access to and supply of goods and services [2004] OJ L 373/37.

Council Decision of 26 November 2009 concerning the conclusion, by the European Community, of the United Nations Convention on the Rights of Persons with Disabilities (2010/48/EC) OJ L 23/35.

Council Decision of 26 November 2009 concerning the conclusion, by the European Community, of the United Nations Convention on the Rights of Persons with Disabilities (2010/48/EC) OJ L 23/35.

\section{INTERNATIONAL TREATIES AND CONVENTIONS}

European Convention for the Protection of Human Rights and Fundamental Freedoms, Rome, 4.XI.1950

UN Convention on the Prevention and Punishment of the Crime of Genocide, approved and proposed for signature and ratification by the UN General Assembly Resolution 260 A (III) of 9 December 1948, entry into force 12 January 1951

International Covenant on Civil and Political Rights, resolution adopted by the UN General Assembly, Resolution 2200A (XXI) of 16 December 1966 entry into force 23 March 1976

International Covenant on Economic, Social and Cultural Rights, resolution adopted by the UN General Assembly, Resolution 2200A (XXI) of 16 December 1966, entry into force 3 January 1976

International Labour Convention No. 159 Concerning Vocational Rehabilitation and Employment (Disabled Persons), adopted in Geneva at the 69th ILC Session (20 June 1983)

UN Convention against Torture and Other Cruel, Inhuman or Degrading Treatment or Punishment, adopted and opened for signature, ratification and accession by the UN General Assembly Resolution 39/46 of 10 December 1984, entry into force 26 June 1987

European Convention for the Prevention of Torture and Inhuman or Degrading Treatment or Punishment, opened for signature on 26, entry into force on 1 February 1989

UN Convention on the Rights of Persons with Disabilities, resolution adopted by the UN General Assembly, 13 December 2006, UN Doc. A/RES/61/106, entry into force 3 May 2008

\section{UN DOCUMENTS}

Office of the United Nations High Commissioner for Human Rights, Equality and nondiscrimination under article 5 of the Convention on the Rights of Persons with Disabilities (9 December 2016), (UN doc A/HRC/34/26)

UNAIDS, 'International Guidelines on HIV/AIDS and Human Rights 2006 Consolidated Version' (UNAIDS 2006) (UN Doc E.06.XIV.4)

- -, 'Mapping of restrictions on the entry, stay and residence of people living with HIV'

(UNAIDS 2009) (UN Doc UNAIDS/09.20E / JC1727E) 
- - 'Global Report: UNAIDS Report on the Global AIDS Epidemic' (UNAIDS 2010) (UN Doc No UNAIDS/10.11E | JC1958E)

United Nations High Commissioner for Human Rights 'The protection of human rights in the context of human immunodeficiency virus (HIV) and acquired immunodeficiency syndrome (AIDS). Commission on Human Rights resolution 1997/33' (UN Doc E/CN.4/RES/1997/33)

- - 'The protection of human rights in the context of human immunodeficiency virus (HIV) and acquired immune deficiency syndrome (AIDS). Commission on Human Rights resolution 1999/49’ (UN Doc E/CN.4/RES/1999/49)

- - 'The protection of human rights in the context of human immunodeficiency virus (HIV) and acquired immune deficiency syndrome (AIDS). Commission on Human Rights resolution 2001/51' (UN Doc E/CN.4/RES/2001/51)

- - 'The protection of human rights in the context of human immunodeficiency virus (HIV) and acquired immunodeficiency syndrome (AIDS). Commission on Human Rights resolution 2003/47’'(UN Doc E/CN.4/RES/2003/47)

- - 'The protection of human rights in the context of human immunodeficiency virus (HIV) and acquired immunodeficiency syndrome (AIDS). Commission on Human Rights resolution 2005/84' (UN Doc E/CN.4/RES/2005/84)

United Nations Human Rights Council 'The protection of human rights in the context of human immunodeficiency virus (HIV) and acquired immunodeficiency syndrome (AIDS) Human Rights Council Resolution 12/27' (UN Doc A/HRC/RES/12/27)

- - 'The protection of human rights in the context of human immunodeficiency virus (HIV) and acquired immunodeficiency syndrome (AIDS) Human Rights Council Resolution 16/28' (UN Doc A/HRC/RES/16/28)

- - 'Special Rapporteur on the rights of persons with disabilities' resolution adopted by the Human Rights Council 26/20’ (UN Doc A/HRC/RES/26/20)

UN Committee on Economic, Social and Cultural Rights, General Comment No. 5 on Persons with disabilities, adopted at the eleventh session of the Committee, 1994), (U.N. Doc $\mathrm{E} / 1995 / 22)$

UN Committee on Economic, Social and Cultural Rights, General Comment No. 18 on the right to work adopted at the thirty-fifth session of the Committee, 2005), (UN Doc E/C.12/GC/18)

UN Committee on the Rights of Persons with Disabilities, Concluding Observations to Spain, adopted at the 6th session (19-23 September 2011), (UN doc CRPD/C/ESP/CO/1)

UN Committee on the Rights of Persons with Disabilities, Inquiry concerning the United Kingdom of Great Britain and Northern Ireland carried out by the Committee under article 6 of the Optional Protocol to the Convention (6 October 2016), (UN doc CRPD/C/15/R.2/Rev.1)

UN Committee on the Rights of Persons with Disabilities, Concluding Observations to Concluding observations on the initial report of the United Kingdom of Great Britain and Northern Ireland, adopted at the 365th session (29 August 2017), (UN Doc $\mathrm{CRPD} / \mathrm{C} / \mathrm{GBR} / \mathrm{CO} / 1$ )

\section{OFFICIAL PAPERS AND POLICY DOCUMENTS}


Department for Communities and Local Government, 'A Framework for Fairness: Proposals for a Single Equality Bill for Great Britain’ (Department for Communities and Local Government 2007)

Department for Education and Employment, Towards Inclusion -civil rights for disabled people (Department for Education and Employment 2001)

- - Towards Inclusion - Civil Rights for Disabled People - Questionnaire (Department for Education and Employment 2001)

<https://www.education.gov.uk/consultations/downloadableDocs/60_4.pdf> accessed 7 July 2016

Department for Exiting the European Union, The United Kingdom's exit from, and new partnership with, the European Union (White Paper, Cm 9417, 2017)

Department of Health, HIV Infected Health Care Workers: Guidance on management and patient notification (Department of Health 2005)

- - Management of HIV-infected healthcare workers: A paper for consultation (Department of Health 2011)

Disability Rights Task Force, From exclusion to inclusion: final report of the Disability Rights Task Force (Department for Work and Pensions 1999)

Dublin Declaration, 'Partnership to fight HIV/AIDS in Europe and Central Asia' (2004) <https://www.unicef.org/eca/ru/Dublin_AIDS_Conference_Breaking_the_Barriers.pdf > accessed 9 May 2018

Equality and Human Rights Commission, 'Employment Statutory Code of Practice: draft for consultation' (2009) <http://www.equality-ne.co.uk/downloads/505_employment_code1.doc> accessed 9 May 2018

Equality and Human Rights Commission, 'Employment Statutory Code of Practice' (Equality and Human Rights Commission 2011)

European Union Committee , European Union - Ninth Report, (HL 1999-2000, 68-I)

Health Protection Agency, 'Occupational transmission of HIV - summary of published reports. March 2005 Edition’ (Health Protection Agency 2005)

- - Testing Times: HIV and other Sexually Transmitted Infections in the United Kingdom (Health Protection Agency 2007)

- - HIV in the United Kingdom: 2009 Report (Health Protection Agency 2009)

HM Treasury, 'The Plan for Growth' (HM Treasury 2011)

International Labour Organisation, An ILO Code of Practice on HIV/AIDS and the World of Work (International Labour Organisation 2001)

- - Recommendation concerning HIV and AIDS and the World of Work, 2010 (No. 200)

(International Labour Organisation 2010)

Joint United Nations Programme on HIV/AIDS, 'Confronting discrimination' (UNAIDS 2017)

Office for Disability Issues, Guidance on matters to be taken into account in determining questions relating to the definition of disability (Office of Disability Issues 2011) 
Public Health England, 'The Management of HIV infected Healthcare Workers who perform exposure prone procedures: updated guidance' (Public Health England 2014)

- - HIV in the UK - Situation Report 2015 Incidence, prevalence and prevention (Public Health England 2015)

- - HIV in the UK: 2016 Report (Public Health England 2016)

- - 'Towards elimination of HIV transmission, AIDS and HIV-related deaths in the UK' (Public Health England 2017)

-- 'Progress towards ending the HIV epidemic in the United Kingdom: 2018 report' (Public Health England 2018)

Select Committee on HIV and AIDS in the United Kingdom, 'No vaccine, no cure: HIV and AIDS in the United Kingdom' (2011)

<http://www.publications.parliament.uk/pa/ld201012/ldselect/ldaids/188/18802.htm> accessed 27 June 2016

'Vilnius Declaration' on Measures to Strengthen Responses to HIV/AIDS in the European Union and in Neighbouring Countries (European Commission 17 September 2004)

<http://ec.europa.eu/health/ph_threats/com/aids/docs/ev_20040916_rd03_en.pdf> accessed 20 November 2017

World Health Organisation, 'International Classification of Impairments, Disabilities and Handicaps: A Manual of Classification Relating to the Consequences of Disease' (World Health Organisation 1980)

- - 'International Classification of Functioning, Disability and Health' (World Health Organisation 2001)

- - 'Consolidated guidelines on the use of antiretroviral drugs for treating and preventing HIV infection' ( $2^{\text {nd }}$ edn, World Health Organisation 2016)

\section{BOOKS/BOOK CHAPTERS/ JOURNAL ARTICLES/ REPORTS AND OTHER}

\section{SOURCES}

NAM Aidsmap, 'Haemophilia and HIV' (NAM Aidsmap 1 October 2009)

<http://www.aidsmap.com/Blood-products-and-haemophilia/page/1324537/ > accessed 8 May 2018

Argyrou A, 'Making the Case for Case Studies in Empirical Legal Research', (2017) 13 Utrecht Law Review, 3 <http://doi.org/10.18352/ulr.409> accessed 20 September 2018

Alonzo A and Reynolds N, 'Stigma, HIV and AIDS: An exploration and elaboration of a stigma trajectory’ (1995) 41(3) Social Science \& Medicine 303

Anderson M and others, 'HIV/AIDS-related stigma and discrimination: Accounts of HIVpositive Caribbean people in the United Kingdom' (2008) 67 (5) Social Science \& Medicine 790

Annequin M and others, 'Increase in Unemployment over the 2000's: Comparison between People Living with HIV and the French General Population' (2016) PLoS ONE 11(11) <https://doi.org/10.1371/journal.pone.0165634> accessed 14 May 2018 
Archer P, 'Independent Public Inquiry Report On NHS Supplied Contaminated Blood and Blood Products' (The Archer Inquiry 2009)

<http://www.archercbbp.com/files/report/76_Lord\%20Archer\%20Report.DOC> accessed 4 July 2009

Annequin M, 'Has the employment status of people living with HIV changed since the early 2000s?'(2015) 9 AIDS 1537

Arnardóttir O, 'Vulnerability under Article 14 of the European Convention on Human Rights. Innovation or Business as Usual?' (2017) 4 Oslo Law Review 3.

Aschbacher R and others 'Evaluation of three different commercial procedures for quantifying human immunodeficiency virus type-1 RNA levels' (1999) New Microbiology 22 (1) 1

Bagenstos S, 'Subordination, Stigma, and "Disability"' (2000) 86 (3) Virginia Law Review 397

Bamforth N and Leyland P, Public Law in a Multi-Layered Constitution (Hart 2003)

Bamforth N, Malik M and O'Cinneide C, Discrimination Law: Theory and Context (Sweet \& Maxwell 2008)

Barnes C, 'A Working Social Model? Disability, Work and Disability Politics in the TwentyFirst Century’ (2000) 20 Critical Social Policy 221

- - and Mercer G. (eds), Exploring the divide: illness and disability (The Disability Press 1996)

Barrett R, 'Elephant people: The phenomena of social withdrawal and self-imposed isolation of people dying with AIDS' (1995) 9 AIDS Patient Care 240

Bayer R, 'Public Health Policy and the AIDS epidemic: An End to HIV exceptionalism?' (1991) 324 (21) New England Journal of Medicine, 1500

- - and Fairchild A, 'Changing the Paradigm for HIV Testing - The End of Exceptionalism' (2006) 355 New England Journal of Medicine 647

Bradley Hare C, 'Clinical Overview of HIV Disease' (HIV Insite, 2017)

<http://hivinsite.ucsf.edu/InSite?page=kb-03-01-01\#S7.2X> accessed 13 November 2017

Beaumont A, 'This Judicial Estoppel has got to stop: Judicial Estoppel and the Americans with Disabilities Act' (1996) 71 New York University Law Review 1529

Bell M, ‘Article 13 EC: The European Commission's Anti-discrimination proposals’ (2000) 29 Industrial Law Journal 79

- - 'Sickness Absence and the Court of Justice: Examining the Role of Fundamental Rights in EU Employment Law' (2005) 21 (5) European Law Journal 641

- - 'Mental Health at Work and the Duty to Make Reasonable Adjustments' (2015) 44 (2) Industrial Law Journal 194

- - and Waddington L, 'Reflecting on inequalities in European Community equality law' [2003] European Law Review 349

- - and Waddington L, 'The Employment Equality Directive and supporting people with psychosocial disabilities in the workplace' (European Commission 2016)

Beren $S$ and others 'The influence of sexual orientation on body dissatisfaction in adult men and women' (1996) 20 International Journal of Eating Disorders 135 
Berger P and Luckmann T, The Social Construction of Reality: A Treatise in the Sociology of Knowledge (Anchor Books 1966)

Bersani L, 'Is the Rectum a Grave?' in Crimp D (ed), AIDS: Cultural Anaylsis/Cultural Activism (MIT Press 1988)

BFI, 'AIDS: Iceberg / Tombstone' (ScreenOnline)

<http://www.screenonline.org.uk/film/id/1210462/index.html> accessed 27 November 2017

Bingham T, The Rule of Law (Penguin 2011)

Blalock A, McDaniel J and Farber E, 'Effect of employment on quality of life and psychological functioning in patients with HIV/AIDS' (2002) 43 (5) Psychosomatics 400

Blumberg S, 'Guarding against threatening HIV prevention messages: An informationprocessing mode’ (2000) 27(6) Health Education \& Behaviour 780

Blustein D and others, 'Lessons in survival: forging an experience-near understanding of the interface of work and health' (2008) 36 (1) Counselling 90

Bojarski L, 'Country report Non-discrimination Poland' (Directorate-General for Justice and Consumers 2015)

Bourne A, 'Making it Count Briefing Sheet I: The Role of Fear in HIV Prevention' (2010) $<$ http://www.sigmaresearch.org.uk/files/MiC-briefing-1-Fear.pdf> accessed 7 July 2016

Boyce P and others, 'Putting sexuality (back) into HIV/AIDS: Issues, theory and practice' (2007) 2 (1) Global Public Health 1

Bradney A, ‘Law as a Parasitic Discipline' (1998) 25 Journal of Law and Society 71

-- 'The Place of Empirical Legal Research in the Law School Curriculum' in Peter Cane and Herbert Kritzer (eds), The Oxford Handbook of Empirical Legal Research (OUP 2010)

Briant E, Watson $\mathrm{N}$ and Philo G, 'Reporting disability in the age of austerity: the changing face of media representation of disability and disabled people in the United Kingdom and the creation of new folk devils' (2013) 28 (6) Disability and Society 874

Bribosia E and Rorive I, 'Reasonable Accommodation Beyond Disability in Europe' (European Commission 2013)

British HIV Association, 'British HIV Association guidelines for the treatment of HIV-1positive adults with antiretroviral therapy 2015' (BHIVA 2016)

<http://www.bhiva.org/documents/Guidelines/Treatment/2016/treatment-guidelines-2016interim-update.pdf> accessed 16 November 2017

Broderick A, The long and winding road to equality and inclusion for persons with disabilities: The United Nations Convention on the Rights of Persons with Disabilities (Intersentia 2015)

Brou $\mathrm{H}$ and others, 'When do HIV-infected women disclose their HIV status to their male partner and why?' (2007) 4 (12) PLoS Med 342

Bryman A, Quantity and Quality in Social Research. (Unwin Hyman 1988)

- - Social Research Methods. Oxford: (Oxford University Press 2012)

Burgoyne R and Saunders D, 'Perceived support in newly registered HIV/AIDS clinic outpatients' (2000) 12 (5) AIDS Care 643 
Burris S, 'Public Health “AIDS Exceptionalism” and the Law' (1994) 27 (2) John Marshall Law Review 251

- - 'Studying the Legal Management of HIV-Related Stigma' (1999) 42 (7) American Behavioural Scientist 1229

- - 'Stigma, ethics and policy: A commentary on Bayer's Stigma and the ethics of public health: Not can we but should we' (2008) 67 (3) Social Science and Medicine 473

Cain M, 'Realist Philosophy and Standpoint Epistemologies of Feminist Criminology as a Successor Science' in Gelsthorpe L and Morris A (eds), Feminist Perspectives in Criminology (Open University Press 1990)

Cambridge P 'How Far to Gay? The Politics of HIV in Learning Disability' (1997) 12 (3) Disability \& Society 427

Cameron G, 'Evil HIV beast took my babies away from me' (The Sun 2010)

<http://www.thescottishsun.co.uk/scotsol/homepage/news/2817429/Evil-HIV-beast-MarkDevereaux-took-my-babies-away-from-me.html> accessed 24 May 2016

CDC, 'Pneumocystis Pneumonia - Los Angeles' (1981) 30(21) Morbidity and Mortality Weekly Report 250

Cederbaum J and others, 'Social networks of HIV-positive women and their association with social support and depression symptoms' (2017) 57 (2) Women \& Health 268

Chalmers J, Legal Responses to HIV and AIDS (Hart Publishing 2008)

Chaney $\mathbf{J}$ and others, 'Attributional style and depression in rheumatoid arthritis: The moderating role of perceived illness control' (1996) 41 (3) Rehabilitation Psychology 205

Charlton J, Nothing About Us Without Us (University of California Press 2000)

Chesney M and Smith A, 'Critical Delays in HIV Testing and Care: The Potential Role of Stigma’ (1999) 42(7) American Behavioral Scientist 1162

Chynoweth P, 'Legal research' in Andrew Knight and Les Ruddock (eds), Advanced Research Methods in the Built Environment (Blackwell 2008), 29

Clifford J, The Predicament of Culture (Harvard University Press 1988)

Cochrane M, When AIDS Began: San Francisco and the Making of an Epidemic (Routledge 2004)

Coffin J and others, 'What to call the AIDS virus?' (1986) Nature. 321 (6065) 10

Collins H, 'Discrimination, Equality and Social Inclusion' (2003) 66 (1) The Modern Law Review 16

Connolly M Discrimination Law (Sweet \& Maxwell 2011)

- - 'The chilling effect and the most ancient form of vengeance: discrimination and victimising third parties ' (2011) 11 (3) International Journal of Discrimination and the Law 123

- - 'Achieving social mobility: the role of equality law' (2013) 13 (4) International Journal of Discrimination and the Law 261

Conviser R and Rutledge J, 'The need for innovation to halt AIDS among intravenous drug users and their sexual partners' (1988) 3 AIDS and Public Policy Journal 43 
Conyers L, Boomer K and McMahon B, 'Workplace discrimination and HIV/AIDS: The national EEOC ADA research project’ (2005) 25 (1) Work 37

Crandall C and Coleman R, 'AIDS-related stigmatization and the disruption of social relationships' (1992) 9 (2) Journal of Social and Personal Relationships 163

Crasnow QC, R and McKinley S, 'The CJEU Judgment in CHEZ: Indirect discrimination by association' (Cloisters, 27 July 2015). <http://www.cloisters.com/blogs/the-cjeu-judgment-inchez-indirect-discrimination-by-association> accessed 30 November 2017

Crawford, R, 'The Boundaries of the Self and the Unhealthy Other: Reflections on Health, Culture and AIDS' (1994) 38 (10) Social Science \& Medicine 1347

Crenshaw K, 'Demarginalizing the Intersection of Race and Sex: A Black Feminist Critique of Antidiscrimination Doctrine, Feminist Theory and Antiracist Politics' [1989] University of Chicago Legal Forum 139

- - 'Mapping the Margins: Intersectionality, Identity Politics, and Violence against Women of Color' (1991) 43 (6) Stanford Law Review 1241

Crimp D, AIDS: Cultural Anaylsis/Cultural Activism (MIT Press 1988)

- - and Rolston A, AIDS Demographics (Bay Press 1990)

Crotty M, The Foundation of Social Research: Meaning and Perspectives in the Research Process (Sage 1998)

Crow L, 'Including all our lives' in Morris J (ed) Encounters with Strangers: Feminism and Disability (Women's Press 1996)

Croxford S and others, 'Mortality and causes of death in people diagnosed with HIV in the era of highly active antiretroviral therapy compared with the general population: an analysis of a national observational cohort' (2017) 2 (1) Lancet Public Health e35. <http://www.thelancet.com/journals/lanpub/article/PIIS2468-2667(16)30020-2/fulltext> accessed 4 December 2017

Cunningham N, 'Discrimination through the looking glass: judicial guidelines on the burden of proof' (2006) 35 (3) Industrial Law Journal 279

Danisi C, 'Protecting the Human Rights of People living with HIV/AIDS: A European Approach?' (2015) 3 (2) Groningen Journal of International Law 47

Darby S and others, 'The impact of HIV on mortality rates in the complete UK haemophilia population.' (2004) 18 (3) AIDS 525

Davis L, The Disability Studies Reader (Routledge 2006)

Dawson R, 'Coping with a dual diagnosis' (2007) 172 AIDS Treatment Update 3

Deckha M 'Is culture taboo - Feminism, Intersectionality and Culture Talk' (2004) 16 (1)

Canadian Journal of Women and the Law 672

de Keijinde Wrankrijker M, 'The long way from the International Classification of Impairments, Disabilities and Handicaps (ICIDH) to the International Classification of Functioning, Disability and Health (ICF)' (2003) 25 (11-12) Disability Rehabilitation 561

Degroote S and others, 'HIV disclosure in the workplace' (2014) 69 (3) International Journal of Clinical and Laboratory Medicine 191 
Degener T, 'International Disability Law - A New Legal Subject on the Rise: The Interregional Experts' Meeting in Hong Kong December 13-17 1999’ (2000) 18 Berkeley J Intl Law 180

- - 'The Definition of Disability in German and Foreign Discrimination Law' (2006)

Disability Studies Quarterly 26 (2) <http://dsq-sds.org/article/view/696/873> accessed 8 May 2018

Delius P and Glaser C 'Sex, Disease and Stigma in South Africa: Historical Perspectives’ (2005) 4 (1) African Journal of AIDS Research 29.

Demi A and others, 'Suicidal thoughts of women with HIV infection: Effect of stressors and moderating effects of family cohesion’ (1998) 12 (3) Journal of Family Psychology 344

Dodds C and others, 'Outsider status: Stigma and discrimination experienced by Gay men and African people with HIV' (Sigma Research 2004)

Dodds N, 'Two for the price of One: An ethnography of an HIV day care clinic for people with a dual diagnosis of HIV and cancer' (The Free Library 2008)

<http://www.thefreelibrary.com/Two+for+the+price+of+one\%3A+life+with+a+dual+diagnos is+of+HIV+and...-a0200343540> accessed 7 July 2016

Douglas N, 'I just get on with it...A study of the employment experiences of gay and bisexual men and black African men and women living with HIV in the UK' (Terence Higgins Trust 2009)

Douglas-Scott S, 'A Tale of Two Courts: Luxembourg, Strasbourg and the Growing Human Rights Aquis’ (2006) 43 (3) Common Market Law Review 629

Dowsett G, 'Some considerations on sexuality and gender in the context of AIDS' (2003) 11 (22) Reproductive Health Matters 21

Doyle B, 'Enabling Legislation or Dissembling Law? The Disability Discrimination Act 1995’ (1997) 60 (1) The Modern Law Review 64.

Dray-Spira R and others, 'Socio-economic conditions, health status and employment among persons living with HIV/AIDS in France in 2001' (2003) 15 (6) AIDS Care 739

- - and others 'Socioeconomic differences in the impact of HIV infection on workforce participation in France in the era of Highly Active Antiretroviral Therapy' (2007) 97 (3) American Journal of Public Health 552

Drimmer J, 'Cripples, Overcomers and Civil Rights: Tracing the Evolution of Federal Legislation and Social Policy for People with Disabilities' (1992) 40 (5) UCLA Law Review 1341

Egan S, ‘The Doctrinal Approach in International Human Rights Scholarship' (2017) UCD Working Papers in Law, Criminology \& Socio-Legal Studies Research Paper No. 19/17 <https://ssrn.com/abstract=3082194> accessed 18 September 2018

Elford J and others, 'HIV in East London: ethnicity, gender and risk. Design and methods' (2006) 6 BMC Public Health 150

Elford J and others, 'Disclosure of HIV status - The role of ethnicity among people living with HIV in London, (2008) 47 Journal of AIDS 514

Elliott R, Utyasheva L and Zack E, 'HIV, disability and discrimination: making the links in international and domestic human rights law' (2009) 12 Journal of the International AIDS Society 29 
Ellis E and Watson P , EU Anti-Discrimination Law (2nd edn, Oxford University Press 2012)

Emlet C, 'An Examination of the Social Networks and Social Isolation in Older and Younger Adults Living with HIV/AIDS' (2006) 31 (4) Health \& Social Work 299

Engel D and Munger F, Rights of Inclusion: Law and Identity in the Life Stories of Americans with Disabilities (University of Chicago Press 2010)

England R, 'Correlates of stigma towards physically disabled person' in Marinelli D and Dell Orto A (eds) The physiological and social impact of physical disability (Springer 1977)

- - 'The dangers of disease specific aid programmes' (2007) 335 British Medical Journal 565

- - 'Writing is on the wall for UNAIDS' (2008) 336 British Medical Journal 1072

Equal Opportunities Commission, 'Formal Investigation Report on the Recruitment and Selection Policy and Practice of Dan Air’ (Equal Opportunities Commission 1987)

European Disability Forum, 'Alternative Report to the UN Committee on the Rights of Persons with Disabilities’ (European Disability Forum 2014)

Eurostat, Disability statistics - barriers to social integration' (25 October 2017)

$<$ http://ec.europa.eu/eurostat/statistics-explained/index.php/Disability_statistics_-

_barriers_to_social_integration> accessed 27 November 2017.

Ewings $\mathrm{F}$ and others 'Survival following HIV infection of a cohort followed from seroconversion in the UK' (2008) 22 (1) AIDS 89

Ezzy D and others, 'Employment, Accommodation, Finances and Combination Therapy: The social consequences of living with HIV/AIDS in Australia' (1998) 10 (Suppl. 2) AIDS Care 189

Ezzy D, de Visser R and Bartos M, 'Poverty, disease progression and employment among people living with HIV/AIDS in Australia’ (1999) 11 (4) AIDS Care 405

Farrell A, The Politics of Blood (Cambridge University Press 2012)

Ferri D and Lawson A, 'Reasonable accommodation for disabled people in employment' (Directorate-General for Justice and Consumers 2016)

Ferris K and Marson J, 'Does Disability Begin at 40? Karsten Kaltoft v Kommunernes Landsforening, acting on behalf of the Municipality of Billund (Advocate General's Opinion)' (2014) 20 Web Journal of Current Legal Issues <http://webjcli.org/article/view/373/476> accessed 29 March 2017

Fevre R and others, 'Fair Treatment at Work Report: Findings from the 2008 Survey: Employment Relations Research Report No. 103' (Department for Business Innovation and Skills 2009)

Fesko S, 'Disclosure of HIV status in the workplace: considerations and strategies' (2001) 26 (4) Health \& Social Work 235

Fitzgerald M “"You look so well” The Multiple Facets of Hidden Disabilities' (2000) 20 (3) Disability Studies Quarterly 254

- - and Paterson K., 'The hidden disability dilemma for the preservation of self' (1995) 2 (1) Journal of Occupational Science 13 
Foblets M and Alidadi K 'Summary Report on the RELIGARE Project' (2013)

<http://www.religareproject.eu/?q=content/final-summary-report-religareproject> accessed: 7 July 2017

Foucault M, Discipline and punish (Pantheon.1977)

- - The history of sexuality, vol 1: an introduction (Random House 1978)

Frame M, 'What's wrong with her? The Stigmatizing effects of an Invisible Stigma' (2000) 20

(3) Disability Studies Quarterly 242

Fraser Butlin S, 'The UN Convention on the Rights of Persons with Disabilities: Does the Equality Act 2010 Measure up to UK International Commitments?' (2011) 40 (4) Industrial Law Journal 428

Fredman S, 'Equality: a new generation?' (2001) 30 Industrial Law Journal 145

- - 'Double trouble: multiple discrimination and EU law', (2005) 2 European Anti-

Discrimination Law Review 13

- - Discrimination Law (Oxford University Press 2011)

- - 'Intersectional discrimination in EU gender equality and non-discrimination law: European network of legal experts in gender equality and non-discrimination' (European Commission, 2016)

- - and others, 'Achieving Transformative Equality for Persons with Disabilities: Submission to the CRPD Committee for General Comment No.6 on Article 5 of the UN Convention on the Rights of Persons with Disabilities' (Oxford Human Rights Hub 2017)

French S, 'Setting a record straight' in Swain J, Finkelstein V, French S and Oliver M (eds), Disabling Barriers - Enabling Environments (Sage 1993)

French S and others, 'Sexual orientation and prevalence of body dissatisfaction and eating disordered behaviors: A population-based study of adolescents' (1996) 19 (2) International Journal of Eating disorders 119

Fuller L, Morality of Law (Yale University Press 1969)

Gable L and others, Legal Aspects of HIV/AIDS: A Guide for Policy and Law Reform (The World Bank 2007)

Gable L, 'Global Assessment of the Role of Law in the HIV/AIDS Pandemic' (2009) 123

Public Health 260

Gallop R, 'The knowledge, attitudes and concerns of hospital staff about AIDS' (1991) 82 (6) Canadian Journal of Public Health 409

Gilbert L, 'The mercurial piece of the puzzle: Understanding stigma and HIV/AIDS in South Africa' (2016) 13 (1) Journal of Social Aspects of HIV/AIDS 8

Gilman S, Disease and Representation: Images of Illness from Madness to AIDS (Cornell University Press 1998).

Gilmore N and Somerville M, 'Stigmatization, scapegoating and discrimination in sexually transmitted disease: Overcoming the "them" and "us"' (1994) 39 (9) Social Science and Medicine 1339

Goffman E, The Presentation of Self in Everyday Life (Penguin 1959) 
- - Stigma notes on the management of spoiled identity (Penguin 1963)

Goldman D and Bao Y, 'Effective HIV Treatment and the Employment of HIV+ Adults' (2004) 39 (6) Health Services Research 1691

Gostin L, 'The Politics of AIDS: Compulsory State Powers, Public Health and Civil Liberties' (1989) 49 Ohio State Law Journal 1017

- - 'Public health strategies for confronting AIDS. Legislative and regulatory policy in the United States' (1989) 26 (11) Journal of the American Medical Association 1621

Gottlieb M and others, 'Pneumocystis carinii Pneumonia and Mucosal Candidiasis in Previosly Healthy Homosexual Men’ (1981) 305 New England Journal of Medicine 1425

Grabham E, 'Taxonomies of Inequality: Lawyers, Maps and the Challenge of Hybridity' (2006) 15 (1) Social \& Legal Studies 5

- - Brewing Legal Times: Things, Form, and the Enactment of Law (University of Toronto Press 2016)

Granger B, 'The role of psychiatric rehabilitation practitioners in assisting people in understanding how to best assert their ADA rights and arrange job accommodations.' (2000) 23 (3) Psychiatric Rehabilitation Journal 23(3) 215.

Green G, 'Attitudes towards people with HIV: are they as stigmatising as people with HIV think they are?' (1995) 41 Social Science \& Medicine 557

- - The End of Stigma? (Routledge 2009)

Grossman A, 'Gay men and HIV/AIDS: Understanding the double stigma' (1991) 2 (4) Journal of the Association of Nurses in AIDS Care 28

Habyarimana J, Mbakile B and Pop-Eleches C, 'The Impact of HIV/AIDS and ARV Treatment on Worker Absenteeism: Implications for African Firms' (2010) 45 Journal of Human Resources 4

Haigh R and Harris D, AIDS: A Guide to the Law (Routledge 1990)

Hamblin J, ‘The role of law in HIV/AIDS policy’ (1991) 5 (Suppl 2) AIDS S239

Hammersley M, What's wrong with ethnography? (Routledge 1992)

Handler J and Hasenfeld H, The Moral Construction of Poverty: Welfare Reform in America (Sage Publications 1991)

Hannaford S, Living outside inside (Canterbury Press 1985)

Hannet S, 'Equality at the Intersections: The Legislative and Judicial Failure to Tackle Multiple Discrimination' (2003) 23 (1) Oxford Journal of Legal Studies 65

Hendriks A, 'The UN Disability Convention and (Multiple) Discrimination: Should EU NonDiscrimination Law Be Modelled Accordingly' (2010) 2 European Year Book of Disability Law 7

Henn M, Weinstein M and Foard N, A short introduction to social research (Sage 2006)

- - A critical introduction to social research (2nd edn, Sage, 2009)

Hepple B, 'The Future of Labour Law' (1995) 24 (4) Industrial Law Journal 303 
- - Coussey M and Choudhury T, Equality: A New Framework (Hart Publishing 2000)

- - Equality: The new legal framework (Hart Publishing 2011)

Herek G, 'AIDS and Stigma' (1999) 42 (7) American Behavioural Scientist 1106.

- - and Capitanio J, 'AIDS Sigma and Sexual Prejudice' (1999) 42 (7) American Behavioural Scientist 1130

- - J Capitanio and K Widaman, 'HIV-related stigma and knowledge in the United States: prevalence and trends 1991-1999' (2002) 92 (3) American Journal of Public Health 371

Hervey $\mathrm{T}$ and Rostant $\mathrm{P}$, 'All About That Bass? Is non-ideal-weight discrimination unlawful in the UK?’ (2016) 79 (2) MLR 248

Hickson F and others, 'Tactical dangers: Findings from the United Kingdom Gay Men's Sex Survey 2008' (Sigma Research 2008)

Hutchinson P and Dhairyawan R, 'Shame, stigma, HIV: philosophical reflections' (2017) Medical Humanities 1

Ibrahim F and others, 'Social and economic hardship among people living with HIV in London' (2008) 9 HIV Medicine 616

International Labour Organisation, 'Structure' (2016) <http://www.ilo.org/global/about-theilo/who-we-are/lang--en/index.htm> accessed 13 May 2016

Jagose A, Queer Theory: An Introduction (New York University Press 1996)

James G, 'An Unquiet Mind in the Workplace: Mental Illness and the Disability Discrimination Act 1995' (2004) 24 Legal Studies 516

Jerrett $\mathrm{M}$ and others, 'A review and evaluation of intraurban air pollution exposure models' (2005) 15 Journal of Exposure Analysis and Environmental Epidemiology 185

Judt T, Postwar - A history of Europe since 1945, (Penguin 2005)

Jones A and others, 'The UN Inquiry into the Rights of Persons with Disabilities in the UK' House of Commons Library Research Paper, Number 07367, 27 March 2017

Joseph S, 'UN Covenants and Labour Rights' in Fenwick C and Novitz T (eds), Human Rights at Work: Perspectives on Law and Regulation (Hart Publishing 2010)

Kaplan J, 'The Definition of Disability: Perspective of the Disability Community' (2000) 3 (2) Journal of Health Care, Law \& Policy 3 (2) 352

Karst K, Belonging to America: Equal Citizenship and the Constitution (Yale University Press 1989)

Kass $\mathrm{N}$ and others, 'Changes in employment, insurance and income in relation to HIV status and disease progression' (1994) 7 (1) Journal of Acquired Immune Deficiency Syndromes 86

Keen S, Employment: Comparing comparators (2011) 161 New Law Journal 308

Keenan M, 'The Politics of Telling: Beyond Similarity and Difference in the interview relationship' (2012) 12 Studies in Qualitative Methodology 91

Keogh P and others, 'Morality, responsibility and risk' (Sigma Research 2006)

Klitzman R Being positive: The lives of men and women with HIV (Ivan R. Dee 1997) 
Kerr A and Shakespeare T, Genetic points: from eugenics to genome (New Clarion Press 2002)

Kersley B and others, Inside the Workplace: Findings from the 2004 Workplace Employment Relations Survey (Routledge 2006)

Klimas T and Vaitiukait J, 'The Law of Recitals in European Community Legislation' (2008) 15 (1) ILSA Journal of International \& Comparative Law 61

Kulkosky J and Nunnari G 'HIV and AIDS: Myths, Facts, and the Future' [2005] Spring Commonhealth 11

Lieberman E, Boundaries of Contagion: How Ethnic Politics Have Shaped Government Responses to AIDS (Princeton University Press 2009)

Kopelman L, 'If HIV/AIDS is Punishment, Who is Bad?' (2002) 27 (2) Journal of Medicine and Philosophy 231

Lawson A, 'Duties to Make Adjustments and Human Rights' in A Lawson (ed), Disability and Equality Law in Britain: The Role of Reasonable Adjustment (Hart Publishing, 2008)

- - 'People with Psychosocial Impairments or Conditions, Reasonable Accommodation and the Convention on the Rights of Persons with Disabilities' (2008) 26 (2) Law in Context 62

- - 'The UN Convention on the Rights of Persons with Disabilities and European Disability Law: A Catalyst for Cohesion' in G Quinn and O Arnardottir (eds) The UN Convention on the Rights of Persons with Disabilities: European and Scandinavian perspectives (Martinus Nijhoff 2009).

- - 'Disability and Employment in the Equality Act 2010: Opportunities Seized, Lost and Generated' (2011) 40 (4) Industrial Law Journal 359

Leigh $\mathrm{J}$ and others, 'Hours at work and employment status among HIV-infected patients' (1995) 9 (1) AIDS 9(1) 81

- - 'Absenteeism and HIV infection' (1997) 4 (5) Applied Economics Letters 275

Leonard A, Employment discrimination against persons with AIDS (1985) 10 (3) University of Dayton Law Review 681

Lessing J, ‘Denial and Disability’ (1981) 11 (5) Off our Backs 21.

Letherby G, Scott J and Williams, Objectivity and subjectivity in social research (Sage 2013)

Link B and Phelan J, 'Conceptualizing stigma' (2001) 27 (1) Annual Review of Sociology 363

Lippmann W, Public Opinion (BN Publishing 2007)

Lipson J 'She's Not Disabled - She Plays Tennis' (2000) 20 (3) Disability Studies Quarterly 281

Lisk F, 'A Rights-based approach to addressing HIV/AIDS in the Workplace: The role of and contribution of the ILO and its Constituents' (2007) (1) Law, Social Justice and Global Development Journal <http://www2.warwick.ac.uk/fac/soc/law/elj/lgd/2007_1/lisk> accessed 17 November 2017 
Liu $\mathrm{H}$ and others, 'Relation of sexual risks and prevention practices with individuals' stigmatising beliefs towards HIV infected individuals: an exploratory study' (2005) 81 Sexually Transmitted Infections 511

Livingstone S, 'Article 14 and the prevention of discrimination in the European Convention on Human Rights' (1997) 1 European Human Rights Law Review 25

Longo $\mathrm{M}$, Sprose $\mathrm{J}$ and Locke A, 'Identifying major concerns of persons with acquired immunodeficiency syndrome' (1990) 4 Clinical Nurse Specialist 21

Lord J, Suozzi D and Taylor A, 'Lessons from the Experience of U.N. Convention on the Rights of Persons with Disabilities: Addressing the Democratic Deficit in Global Health Governance' (2010) 38 (3) The Journal of Law, Medicine \& Ethics 564

Mabbett D, 'The Development of Rights-based Social Policy in the European Union: The Example of Disability Rights' (2005) 43 Journal of Common Market Studies 97

Mahajan A and others, 'Stigma in the HIV/AIDS epidemic: A review of the literature and recommendations for the way forward' (2008) 22 AIDS S67

Mann J, 'Health and human rights: if not now, when?' (2007) 2 (3) Health and Human Rights 113

- - and others, 'Health and Human Rights' (1996) 1 (1) Health and Human Rights 7

Mannucci P, 'Back to the future: a recent history of haemophilia treatment' 200814 (3)

Haemophilia 10

Martin D and others, 'Perceived employment barriers and their relation to workforce-entry intent among people with HIV/AIDS' (2003) 8(3) Journal of Occupational Health Psychology 181

Mason J, Qualitative Researching ( $2^{\text {nd }}$ edition, Sage 2002)

Masters D and McKinley S, 'Indirect discrimination by association: a regressive step?' (Cloisters, 30 March 2015) < http://www.cloisters.com/latest/indirect-discrimination-byassociation-a-regressive-step> accessed 30 November 2017

Maticka-Tyndale E, Adam B and Cohen J, 'To Work or Not to Work: Combination Therapies and HIV' (2002) 12 (10) Qualitative Health Research 1353

McClean P, 'Brexit timeline: key dates in UK's divorce with EU' Financial Times (London, 14 June 2017)

McConnachie C, 'Human Dignity, Unfair Discrimination and Guidance' (2014) 34 (3) Oxford Journal of Legal Studies 609

McReynolds C, 'The meaning of work in the lives of people living with HIV disease and AIDS' (2001) 44 (2) Rehabilitation Counselling Bulletin 104

McTigue P, 'The challenge of HIV - Social stigma or disability?' [2010] 5 Web JCLI $<$ http://webjcli.ncl.ac.uk/2010/issue5/mctigue5.html> accessed 13 December 2017

- - 'From Navas to Kaltoft: The European Court of Justice's evolving definition of disability and the implications for HIV-positive individuals' (2015) 15 (4) International Journal of Discrimination and the Law 241

Mello J, 'Ethics in Employment Law: The Americans with Disabilities Act and the Employee with HIV' (1999) 20 (1) Journal of Business Ethics 67 
Mitchell D, 'Collateral damage' (New Law Journal, 12 February 2016) <https://www.newlawjournal.co.uk/content/collateral-damage> accessed 30 November 2017

Murphy P and others, 'Serostatus Disclosure, Stigma Resistance, and Identity Management Among HIV-Positive Gay Men in Ireland' (2016) 26 (11) Qualitative Health Research 1459

Morris, J., 1991. Pride against prejudice. London: Women's Press.

NAM: Aidsmap, 'Social and Legal Issues for People with HIV’ (NAM Aidsmap 2010)

National AIDS Trust, HIV: Public Knowledge and Attitudes 2014 (National AIDS Trust 2014).

- - 'March Budget takes rights away from people with HIV' (2010)

<www.nat.org.uk/NewsandMedia/PressReleases/2011/March/Budget\%20takes\%20rights\%20 away\%20from\%20people\%20with\%20HIV.aspx> accessed 13 June 2010

- - 'One in five adults do not realise HIV is transmitted through sex without a condom between a man and a woman' (2011) <http://www.nat.org.uk/News-and-Media/PressReleases/2011/February/MORI\%20survey\%20-

\%20knowledge\%20and\%20attitudes\%20to\%20HIV.aspx > accessed 17 June 2014

Napier B, 'AIDS, Discrimination and Employment Law' (1989) 18 (2) Industrial Law Journal 84

- - and others, Harvey on Industrial Relations and Employment Law (LexisNexis 2018)

Newman D, 'Indirect Discrimination’ (2011) 209 Equal Opportunities Review 22

Niehaus I, 'Death Before Dying: Understanding AIDS Stigma in the

South African Lowveld' (2007) 33 (4) Journal of Southern African Studies 845

Northrop J, 'A dirty little secret: stigma, shame and hepatitis C in the health setting' (2017) 43 Medical Humanities 218

Noy C, 'Sampling Knowledge: The Hermeneutics of Snowball Sampling’ (2008) 11 (4) International Journal of Social Research Methodology 327

O'Dowd, M 'Psychosocial issues in HIV infection' (1988) 2 (Suppl.1) AIDS S201

Oliver M, The Politics of Disablement (Palgrave Macmillan 1990)

- - Understanding Disability: From Theory to Practice (Palgrave Macmillan 1996)

- - Understanding Disability: From Theory to Practice (2nd edition, Palgrave Macmillan 2009)

Oppenheimer G, 'Causes, cases, and cohorts: The role of epidemiology in the historical construction of AIDS' in E Fox and D Fee (eds), AIDS. The Making of a Chronic Disease (University of California Press 1996).

Orr A, 'Legal AIDS: Implications of AIDS and HIV for British and American law' (1989) 15 (2) Journal of Medical Ethics 61

Oulton R, 'Employment / Discrimination: When is a clone not a clone?' (2009) 159 (26) New Law Journal 1158

Parsons T, 'Definitions of Health and Illness in the Light of American Values and Social Structure' in E Jaco (ed), Patients, Physicians and Illness (Free Press 1958) 
Parker R and Aggleton P 'HIV and AIDS-related stigma and discrimination: a conceptual framework and implications for action’ (2003) 57 (1) Social Science \& Medicine 13

Patterson D and London L, 'International law, human rights and HIV/AIDS' (2002) 80 (12)

Bulletin of the World Health Organization 964

Patton C, Sex and Germs:The Politics of AIDS. (South End Press 1985)

Petro A, After the Wrath of God: AIDS, Sexuality, and American Religion (Oxford University Press 2015)

Petros G and others, 'HIV/AIDS and 'Othering' in South Africa: The Blame Goes On!' (2006) 8 (1) Culture, Health \& Sexuality 67

Peroni L and Timmer A, 'Vulnerable groups: The promise of an emerging concept in European Human Rights Convention law' (2013) 11 (4) International Journal of

Constitutional Law 1056

Posel D, 'Sex, Death and the Fate of the Nation: Reflections on the Politicisation of Sexuality in Post-apartheid South Africa' (2005) 75 (1) Africa 125

Power H, 'HIV/AIDS, Sex and the Criminal Law' (1997) 19 (3) Journal of Social Welfare and Family Law 343

Quinn P and De Hert P 'Self respect—A "Rawlsian Primary Good" unprotected by the European Convention on Human Rights and its lack of a coherent approach to stigmatization?' (2014) 14 (1) International Journal of Discrimination and the Law19

Quinn G, 'The International Covenant on Civil and Political Rights' in Degener T and KosterDreese Y (eds) Human Rights and Disabled Persons (Martinus Nijhoff 1995)

- - and Degener T, Human Rights and Disability: The Current Use and Future Potential of UN Human Rights Instruments in the Context of Disability UN Publications, 2002)

- - and Arnardottir O (eds), The UN Convention on the Rights of Persons with Disabilities:

European and Scandinavian perspectives (Martinus Nijhoff 2009)

Ramsay I, 'Models of Consumer Bankruptcy: Implications for Research and Policy' (1997) 20 Journal of Consumer Policy 269

Raz J, The authority of law: Essays on law and morality (Oxford University Press 1979)

Reinharz S, 'Experiential analysis: A contribution to feminist research' in G Bowles and R Duelli Klein (eds) Theories of Women's Studies (Routledge 1983)

Reaume D, 'Discrimination and Dignity' in C. McCrudden (ed), Anti-discrimination Law (Ashgate Publishing 2004)

Ritchie J and Lewis J, Qualitative Research Practice (Sage 2013)

Rodger A and others, 'Sexual Activity Without Condoms and Risk of HIV Transmission in Serodifferent Couples When the HIV-Positive Partner Is Using Suppressive Antiretroviral Therapy' (2016) Journal of the American Medical Association 316 (2) 171

Rodkjaer L and others 'Disclosure decisions: HIV-positive persons coping with diseaserelated stressors' (2011) 21 (9) Qualitative Health Research 1249

Romm N, 'Becoming More Accountable: A Comment on Hammersley and Gomm' (1997) 2 (3) Sociological Research Online <http://www.socresonline.org.uk/2/3/2.html> accessed 1 December 2017 
Rosenbrock R and others, 'The normalization of AIDS in Western European countries' (2000) 50 Social Science \& Medicine 1607

Ruby J, 'Exposing yourself: Reflexivity, anthropology, and film’ 30 1⁄2 Semiotica 153

Salter M and Mason J, Writing Law Dissertations: An Introduction and Guide to the Conduct of Legal Research (Pearson 2007), 31

Samji H and others, 'Closing the Gap: Increases in Life Expectancy among Treated HIVPositive Individuals in the United States and Canada' (2013) 8 (12) PLoS ONE <https://doi.org/10.1371/journal.pone.0081355> accessed 13 November 2017

Sargeant M, 'Disability and age - multiple potential for discrimination' (2005) 33 (1) International Journal of the Sociology of Law 17

- - 'Older Workers and the need for Reasonable Accommodation'(2008) 9 (3) International Journal of Discrimination and the Law 163

Scambler G, 'Sociology, social structure and health-related stigm' (2006) 11 (3) Psychology, Health and Medicine 288

- - and Paoli F, 'Health Work, Female Sex Workers and HIV/AIDS: Global and Local Dimensions of Stigma and Deviance as Barriers to Effective Interventions' (2008) 66 Social Science and Medicine 1848

Scheper-Hughes $\mathrm{N}$ and Lock M, 'The message in the bottle: Illness and the micropolitics of resistance' (1991) 18 (4) Journal of Psychohistory 409

Schiek D, 'Intersectionality and the Notion of Disability in EU discrimination law' (2016) 53 (1) Common Market Law Review 35

Schiller N, Crystal S and Lewellen D, 'Risky Business: The Cultural Construction of AIDS Risk Groups' (1994) 38 (10) Social Science \& Medicine 1337

Schneider E and others, 'Revised Surveillance Case Definitions for HIV Infection Among Adults, Adolescents, and Children Aged < 18 Months and for HIV Infection and AIDS Among Children Aged 18 Months to <13 Years' (2008) 57(RR-10) Morbidity and Mortality Weekly Report 1

Schuklenk U, AIDS: Society, Ethics and Law, (Dartmouth Publishing Company 2001)

Shacklock G and Smyth J, Being Reflexive in Critical Educational and Social Research (Falmer 2008)

Sherry M 'Overlaps and contradictions between queer theory and disability studies' (2004) 19 (7) Disability \& Society 769

Shakespeare, $\mathrm{T}$ 'Disability, identity and difference' in Barnes $\mathrm{C}$ and Mercer G (eds) Exploring the divide: illness and disability (The Disability Press 1996)

-- K Gillespies-Sells and D Davies, The Sexual Politics of Disability: Untold Desires (Cassell 1996)

- - and Nicholas Watson, 'The social model of disability: an outdated ideology?' (2001) 2

Research in Social Science and Disability 9

Shilts R, And the Band Played On (St Martin's Press 1988) 
Simbayi L and others, 'Measuring AIDS stigmas in people living with HIV/AIDS: the Internalized AIDS-Related Stigma Scale’ (2009) 21 (1) AIDS Care 27

Simoni J, Mason H and Marks G, 'Disclosing HIV status and sexual orientation to employers' (1997) 9 (5) AIDS Care 589

Skidmore P, 'EC framework employment directive on equal treatment in employment: towards a comprehensive community anti-discrimination policy?' (2001) 30 Industrial Law Journal 126

Slapper G and Kelly D, The English Legal System (16 ${ }^{\text {th }}$ edn Routledge 2015)

Smart J, ‘Realism v. Idealism’ (1986) 61 (237) Philosophy 295

Smit $\mathrm{P}$ and others, 'HIV-related stigma within communities of gay men: A literature review' (2012) 24 (4) AIDS Care 405

Smith K and Whiteside A, 'The history of AIDS exceptionalism' (2010) 13 Journal of the International AIDS Society 47

Smookler J, 'Making a Difference? The Effectiveness of Pre-Legislative Scrutiny' (2006) 59 (3) Parliamentary Affairs 522

Soames-Job R, 'Effective and ineffective use of fear in health promotion campaigns' (1988) 78 (2) American Journal of Public Health 163

Solanke I, 'Infusing the Silos in the Equality Act 2010 with Synergy' (2011) 40 (4) Industrial Law Journal 336

- - 'Intersectionality and the "anti-stigma principle" - disrupting anti-discrimination law' (2017) 61 Discrimination Law Association Briefings 10

Sontag S, AIDS and Its Metaphors (Penguin 1989)

Stangor C, Stereotypes and Prejudice: Essential Readings (Psychology Press 2000)

Stangl A and others, 'A systematic review of interventions to reduce HIV-related stigma and discrimination from 2002 to 2013: how far have we come?' (2013) 16 (3) J Int AIDS Soc 18734

Sterne $\mathbf{J}$ and others, 'Long-term effectiveness of potent antiretroviral therapy in preventing AIDS and death: a prospective cohort study’(2005) 9483 The Lancet 378

Stoddard T, 'Don't call it AIDS' New York Times (New York, 17 August 1994) 15

Studdert D, 'Charges of Human Immunodeficiency Virus Discrimination in the Workplace: The Americans with Disabilities Act in Action' (2002) 156 (3) American Journal of Epidemiology 219

Swain J and others (eds) Disabling Barriers Enabling Environments (Sage Publications 1993)

Terence Higgins Trust, 'Positive Voices’ (Terence Higgins Trust 2017)

- - 'Work Positive' (Terence Higgins Trust 2017)

The Antiretroviral Therapy Cohort Collaboration, 'Survival of HIV-positive patients starting antiretroviral therapy between 1996 and 2013: a collaborative analysis of cohort studies' (2017) 4 The Lancet 349 
The People Living with HIV Stigma Survey UK, 'HIV in the UK: Changes and Challenges; Actions and Answers - The People Living With HIV Stigma Survey UK 2015 (The People Living with HIV Stigma Survey UK 2015)

The Washington Post/Kaiser Family Foundation, 2012 Survey of Americans on HIV/AIDS (Kaiser Family Foundation 2012)

Thornicroft G, Shunned: Discrimination against people with Mental Illness (Oxford University Press 2006)

The Electoral Commission, 'EU referendum results' (15 August 2016) $<$ https://www.electoralcommission.org.uk/find-information-by-subject/elections-andreferendums/past-elections-and-referendums/eu-referendum/electorate-and-countinformation> accessed 14 December 2017

Timmer A, 'Toward an Anti-Stereotyping Approach for the European Court of Human Rights’ (2011) 11 (4) Human Rights Law Review 707

Tierney S, 'A Reluctance to be Defined "Disabled". How can the Social Model of Disability Enhance Understanding of Anorexia?’ (2001) 16 (5) Disability \& Society 749

Treichler P, 'AIDS, Homophobia, and Biomedical Discourse: An Epidemic of Signification' in Crimp D (ed) AIDS: Cultural Analysis Cultural Activism (MIT Press 1988)

- - How to have Theory in an Epidemic: Cultural Chronicles of AIDS (Duke University Press 1999)

TSO, 'Equality Act 2010: Explanatory Notes' (TSO 2010)

Turan J and others, 'HIV/AIDS stigma and refusal of HIV testing among pregnant women in rural Kenya: results from the MAMAS study’ (2011) 15 (6) AIDS Behaviour 111

UNAIDS, 'Belarus confirms it applies no restrictions on entry, stay and residence for people living with HIV' (UNAIDS 2015)

<http://www.unaids.org/en/resources/presscentre/pressreleaseandstatementarchive/2015/april/ 20150409_PS_Belarus> accessed 27 November 2017

UNAIDS, WHO and OHCHR, Disability and HIV Policy Brief (United Nations 2009) <www.who.int/disabilities/jc1632_policy_brief_disability_en.pdf> accessed 23 November 2017.

UPIAS, Fundamental Principles of Disability (Union of the Physically Impaired against Segregation 1976)

Van Hoecke M, 'Legal Doctrine: Which Method(s) for What Kind of Discipline?' in Mark Van Hoecke (ed), Methodologies of Legal Research : Which Kind of Method for What Kind of Discipline? (Hart 2011), 18

Vernazza P and others, 'Les personnes séropositives nesouffrant d'aucune autre MST et suivant un traitement antirétroviral efficace ne transmettent pas le VIH par voie sexuelle' (2008) Bull. Med. Suisse (89) 165

Vickers L, 'Religion and Belief Discrimination in Employment - the EU law' (European Commission 2006)

Waddington L and Bell M, 'More equal than others: distinguishing European Union equality directives' (2001) 38 Common Market Law Review 587 
Waddington L, 'Implementing the Disability Provisions of the Employment Framework Directive' in A Lawson and C Gooding (eds) Disability Rights in Europe: From theory to practice (Hart 2005)

- - 'Reasonable Accommodation' in Schiek D, Waddington L and Bell M(eds), Cases, Materials and Text on National, Supranational and International Non-Discrimination Law (Hart Publishing, 2007)

- - 'Breaking New Ground: The Implications of Ratification of the UN Convention on the Rights of Persons with Disabilities for the European Community' in Quinn G and Arnardottir $\mathrm{O}$ (eds) The UN Convention on the Rights of Persons with Disabilities: European and Scandinavian perspectives (Martinus Nijhoff 2009)

- - 'Reasonable Accommodation: Time to Extend the Duty to Accommodate Beyond Disability?’ (2011) 36 (2) NTM|NJCM-Bulletin 186

- - 'HK Danmark (Ring and Skouboe Werge), interpreting EU equality law in light of the UN Convention on the Rights of Persons with Disabilities' (2013) 17 European Antidiscrimination Law Review 11

- - 'Fine-tuning non-discrimination law: Exceptions and justifications allowing for differential treatment on the ground of disability' (2015) 15 (1) International Journal of Discrimination and the Law 11

- - 'Saying all the right things and still getting it wrong: The Court of Justice's definition of disability and non-discrimination law' (2015) 22 (4) Maastricht Journal of European and Comparative Law 576

- - and Broderick A, Promoting Quality and Non-Discrimination for Persons with Disabilities' (Council of Europe 2017)

Wadham J, Blackstone's Guide to the Equality Act 2010 (Oxford University Press 2012)

Ware N, Wyatt M and Tugenberg T, 'Social relationships, stigma and adherence to antiretroviral therapy for HIV/AIDS’ (2006) 18 (8) AIDS Care 904

Warrell D, Cox T and Firth J (eds), Oxford Textbook of Medicine (5th edn Oxford University Press 2010)

Watney S, Practices of freedom: Selected writings on HIV/AIDS (Duke University Press 1994)

- - 'The Spectacle of AIDS' in Crimp D (ed) AIDS: Cultural Anaylsis/Cultural Activism (MIT 1988)

Watson N, 'Well, I know this is going to sound very strange to you, but I don't see myself as a disabled person: identity and disability' (2002) 17 (5) Disability \& Society 509

Watt R, 'HIV, Discrimination, Unfair Dismissal and Pressure to Dismiss' (1992) 21 (4)

Industrial Law Journal 280

Weait M, 'Criminal Law and the Sexual Transmission of HIV' (2007) 68 (1) The Modern

Law Review 121

- - Intimacy and Responsibility: The Criminalisation of HIV Transmission (Routledge 2007)

Weatherburn P and others, 'The growing challenge: A strategic review of HIV social care, support and information services across the UK' (Sigma Research 2007) 
Wells K, 'The Impact of the Framework Employment Directive on UK Disability Discrimination Law' (2003) 32 (4) Industrial Law Journal 254

Wendell S, ‘Toward a Feminist Theory of Disability’ (1989) 4 (2) Hypatia, 104

- - The Rejected Body: Feminist Philosophical Reflections on Disability (Routledge 1996)

Whittle, R 'Disability Discrimination and the Amsterdam Treaty' (1998) 23 European Law Review 50

Wildhaber L Judge, 'Protection against Discrimination under the European Convention on Human Rights - A Second Class Guarantee' (2002) 2 Baltic Yearbook of International Law 71

Williams M and May T, Introduction to the philosophy of social research (UCL Press 1996)

Wilson P, 'Colleague or viral vector? The legal construction of the HIV-Positive Worker' (1994) 16 (3) Law and Policy 293

Wintemute R, 'Within the ambit: how big is the "gap" in Article 14 European Convention on Human Rights?' (2004) 4 European Human Rights Law Review 366

Woodhams C, 'Disability in the Workplace: Hidden Disabilities and Human Resources Practice' (2000) 20 (3) Disability Studies Quarterly 273

- - and Corby S, 'Defining Disability in Theory and Practice: A Critique of the British Disability Discrimination Act 1995' (2003) 32 (2) Journal of Social Policy 159

Work and Pensions Committee, The Equality Bill: How disability equality fits within a single Equality Act (HC 2008-09, 158-II)

World Bank, 'Legal Aspects of HIV/AIDS: A Guide for Policy and Law Reform' (World Bank 2007)

Worthington C and Krentz K, 'Socio-economic factors and health-related quality of life in adults living with HIV' (2005) 16 (9) Int J STD AIDS 608

Varul M, 'Talcott Parsons, the Sick Role and Chronic Illness' (2010) 16 (2) Body \& Society 72

Yallop S, 'Positive employment service - facilitating employment for people living with HIV' (1999) 13 (3) Work 211 


\section{APPENDICES}




\section{APPENDIX 1: CORRESPONDENCE FROM \\ OFFICE FOR DISABILITY ISSUES DATED}

\section{AUGUST 2012}

Mr Peter McTigue

peter.mctigue@ntu.ac.uk

12 August 2012

Fol 2947

Dear Mr McTigue,

Thank you for your Freedom of Information request received on 16 July 2012. You asked :-

I am making a request under the Freedom of Information Act 2000 concerning the consultation responses received by the Government with regard to the extension of the Disability Discrimination Act 1995, by the Disability Discrimination Act 2005, to deem people with HIV as disabled people for the purposes of the 1995 Act from the point of diagnosis.

I should be grateful if you would supply the consultation responses, if any, received from the following organisations:

* The National AIDS Trust,

* Terrence Higgins Trust,

* Positively Women,

* Oasis North London,

* Positive East

* UK Coalition of People Living With HIV and AIDS.

For your information, the consultation exercise in question was undertaken during 2001 and was carried out in the context of "Towards Inclusion" which was the Government's response to the recommendations made by the Disability Rights Task Force in its report "From Exclusion to Inclusion". 
I should be grateful if you would acknowledge safe receipt of this email and I look forward to receiving your response.

Peter McTigue

Senior Lecturer in Law

Nottingham Law School

Burton Street

Nottingham

NG1 4BU

The Department for Work and Pensions has carried out a thorough search of the filed responses for the information that you requested. In the questionnaire "Towards Inclusion - Civil Rights for Disabled

People" there was only one question about people with HIV. In reply to this question: "Do you agree that HIV infection should count as a disability under the Disability Discrimination Act (DDA) from when it is diagnosed? (Para 3.11) the National Aids Trust answered "Yes".

We have not been able to locate consultation responses from the other organisations that you have enquired about.

If you have any queries about this letter please contact me quoting the reference number above.

Yours sincerely ,

Stewart Whyte

Disability Directorate

\section{Your right to complain under the Freedom of Information Act}

If you are not happy with this response you may request an internal review by e-mailing freedom-of-information-request@dwp.gsi.gov.uk or by writing to DWP, Central Fol Team,

Caxton House, Tothill Street, SW1H 9NA. Any review request should be submitted within two months of the date of this letter.

If you are not content with the outcome of the internal review you may apply directly to the Information Commissioner's Office for a decision. Generally the Commissioner cannot make a decision unless you have exhausted our own complaints procedure. The Information Commissioner can be contacted at: The Information Commissioner's Office, Wycliffe House, Water Lane, Wilmslow Cheshire SK9 5AF www.ico.gov.uk 


\section{APPENDIX 2: CORRESPONDENCE FROM}

\section{OFFICE FOR DISABILITY ISSUES DATED}

20 SEPTEMBER 2012

\section{DV/D Department for Work and Pensions}

Website: www.dwp.gov.uk

Peter McTigue

Senior Lecturer in Law

Nottingham Law School

Burton Street

Nottingham

NG1 4BU
Your Reference:

Our Ref: Fol 3437

Date: 20 September 2012

Dear Mr McTigue

Thank you for your Freedom of Information request received on 5 September 2012. You asked:

Many thanks for your response.

I am now making a further request under the Freedom of Information Act 2000 concerning the consultation response received by the Government with regard to the extension of the Disability Discrimination Act 1995, by the Disability

Discrimination Act 2005.

I should be grateful if you would supply the consultation response received from the The National AIDS Trust in its entirety. This was submitted in response to the questionnaire, "Towards Inclusion - Civil Rights for Disabled People"

For your information, the consultation exercise in question was undertaken during 2001 and was carried out in the context of "Towards Inclusion" which was the Government's response to the recommendations made by the Disability Rights Task Force in its report "From Exclusion to Inclusion.

The Department for Work and Pensions has carried out a thorough search of the filed responses for the information that you requested. We have not been able to locate the original consultation response document from the National Aids Trust. We do have an Excel 
spreadsheet record of the responses provided to the Consultation by the National Aids Trust and where these are recorded on that document, they are reproduced below:

1. Do you agree that HIV infection should count as a disability under the Disability Discrimination Act (DDA) from when it is diagnosed? (Para 3.11)

\section{National Aids Trust reply: $\quad$ Yes}

2. Do you agree that people with cancer should count as disabled under the DDA from the time the cancer is diagnosed as being likely to require substantial treatment? (Paras $3.11-3.12$ )

3. Do you agree that people who are registered with a local authority as blind or partially sighted and people who are certified with an ophthalmologist as blind or partially sighted should be conclusively presumed to meet the DDA definition of disability? (Para 3.14)

\section{National Aids Trust reply: $\quad$ Yes Additional comment: \\ "The duty should be proactive".}

\section{Employment}

4. Do you agree that the Government should remove the DDA provision which means that employers can justify failure to make a reasonable adjustment? This defence can be covered by the requirement for only reasonable adjustments to be made. (Para 3.26)

5. Do you agree that the list of examples of DDA adjustments that employers might make should be extended to include - "training in disability issues or in the use of equipment" and "providing support or access to external support"? (Para 3.26)

6. Businesses with fewer than 15 employees are currently exempt from the DDA's employment provisions. Do you agree that all small employers (including anyone taking on their first employee) should be covered by the employment provisions from October 2004? This is the same date that businesses of all sizes providing services to the public would also be covered by the final elements of the DDA duties on service providers. (Para $3.31-3.32$ )

7. Do you agree that business partners, and people who are setting up as business partners, should be covered by the employment provisions of the DDA? (Para 3.34)

7b. Do you agree that the cost of adjustments for disabled partners should be shared by all the partners in the partnership? (Para 3.34) 
8. Do you agree that police officers should be covered by the employment provisions of the DDA? (Paras 3.34-3.35)

National Aids Trust reply: Yes

9. Do you agree that prison officers should be covered by the employment provisions of the DDA? (Paras 3.34-3.35)

National Aids Trust reply: $\quad$ Yes

10. Do you agree that fire-fighters should be covered by the employment provisions of the DDA? (Paras 3.34-3.35)

National Aids Trust reply: Yes

11. Do you agree that barristers in chambers and barristers' pupils should be covered by the employment provisions of the DDA? (Para 3.34)

National Aids Trust reply: Yes

12. Do you agree that in Scotland, advocates' pupils should be covered by the employment provisions of the DDA? (Para 3.34)

National Aids Trust reply: Yes

13. Do you agree that members of county, district and London borough councils should be covered by the employment provisions of the DDA? (Para 3.34)

14. Do you agree that employees on board a ship, aeroplane or hovercraft registered in Great Britain should be covered by the employment provisions of the DDA (unless they do their work entirely outside Great Britain)? (Para 3.34)

National Aids Trust reply: Yes

15. Do you agree that the Government should amend the DDA so that tribunals can consider former employees' claims of disability discrimination which has taken place within six months of the end of employment? The alleged discrimination would have to have arisen directly out of the employment. Claims about discrimination which occur after 6 months could be considered if it was just and equitable to do so. (Paras $3.39-3.40$ )

National Aids Trust reply: $\quad$ Yes 
16. Do you agree that the Government should take the power to bring a range of voluntary workers into the DDA? This power would be used only if necessary. (Para 3.42)

National Aids Trust reply: $\quad$ Yes

Notable comment:

\section{All cancers mentioned should remain included in the list.}

17. Do you agree that public bodies should be placed under a legal duty to promote equality of opportunity for disabled people? (Paras $3.44-3.45)$

National Aids Trust reply: $\quad$ Yes

\section{Notable comment:}

Strongly agree

18. Do you consider that local authorities should be allowed, if they wish, to appoint from a shortlist made up exclusively of disabled applicants who meet the relevant competencies - with a reasonable adjustment if necessary - and not interview suitable non-disabled candidates? (Para 3.49)

\section{National Aids Trust reply: $\quad$ Yes}

19. Do you agree that employment tribunals should be able to order reinstatement or re-engagement under the employment provisions of the DDA? Currently, they can only recommend re-instatement or re-engagement. (Para 3.51)

20a. Do you agree that the time limit for issuing a DDA questionnaire by disabled people should be extended to 4 weeks? The questionnaire procedure allows disabled people to ask why a person, such as an employer, may have discriminated against them. Currently, a questionnaire must be issued within 3 weeks of a complaint being made to a tribunal about an alleged incidence of discrimination. (Para 3.51)

20b. Do you agree that there should be a time limit for an employer to reply to a questionnaire of within 8 weeks of it being issued? Currently there is no time limit. (Para 3.51)

20c. Do you agree that tribunals should be required to draw any inferences that are just and equitable if someone fails to reply to a questionnaire? Currently, tribunals are allowed, but not required, to do this. (Para 3.51)

21. Do you agree that disabled people should have the right to complain to Employment Tribunals about discrimination by managers or trustees of an occupational pension scheme? 
Currently, they can complain to the Pensions Ombudsman. (Para 3.60)

22. Do you agree that it should be unlawful under the DDA for employers to instruct or pressurise other people to discriminate and that the Disability Rights Commission (DRC) should be able to take action in such situations? (Para 3.66)

\section{Access to goods, facilities and services and sale, letting and management of premises}

23. The DDA provisions dealing with the disposal of residential premises has an exemption for small dwellings with fewer than six occupants in addition to the occupier and their family. Do you agree that the Government should create a reserve power, to be used only if shown to be necessary, to reduce the exemption figure below six persons? (Para 3.72)

24. Discrimination is already unlawful where public authorities are providing services to members of the public. Do you agree that discrimination against disabled people should be made unlawful if public authorities do it when they are exercising other public functions? (Para 3.79)

25. Do you have views on whether people who let or manage premises should be covered by the duty to make reasonable adjustments - specifically adjustments to policies, practices and procedures and the provision of auxiliary aids and services? (Para 3.83)

26. Do you have views on the factors which should be taken into account when deciding on whether or not it would be reasonable for a landlord to refuse to let a disabled tenant make changes to physical features of the premises? (Para 3.83)

27. Please list the barriers you feel exist in the provision of services and equipment to disabled people by Government Departments and agencies. Please comment on how these might be removed. (Paras $3.84-3.89$ )

28. We welcome comments on any other recommendations and the report in general, especially practical suggestions for implementation. Your comments will be passed on to the relevant Department.

If you have any queries about this letter please contact me quoting the reference number above. 
Yours sincerely,

Stewart Whyte

Independent Living \& Office for Disability Issues

\section{Your right to complain under the Freedom of Information Act}

If you are not happy with this response you may request an internal review by emailing freedom-of-information-request@dwp.gsi.gov.uk or by writing to DWP, Central Fol Team, Caxton House, Tothill Street, SW1H 9NA. Any review request should be submitted within two months of the date of this letter.

If you are not content with the outcome of the internal review you may apply directly to the Information Commissioner's Office for a decision. Generally the Commissioner cannot make a decision unless you have exhausted our own complaints procedure. The Information Commissioner can be contacted at: The Information Commissioner's Office, Wycliffe House, Water Lane, Wilmslow Cheshire SK9 5AF www.ico.gov.uk 


\title{
APPENDIX 3: TIMELINE OF THE PASSAGE OF THE DISABILITY DISCRIMINATION BILL $\underline{2005}$
}

\author{
$\underline{\text { Parliamentary Passage of the Disability Discrimination Bill }}$
}

$\underline{\text { Stage }}$

Date

House of Lords First Reading

25 November 2004

House of Lords Second Reading

6 December 2004

House of Lords Committee Stage

20 January 2005

House of Lords Report Stage

8 February 2005

House of Lords Third Reading

28 February 2005

House of Commons First Reading

1 March 2005

House of Commons Second Reading

23 March 2005

House of Commons Committee Stage

6 April 2005

House of Commons Report Stage

6 April 2005

House of Commons Third Reading

6 April 2005

Commons' amendments agreed to in the Lords

7 April 2005

Royal Assent

7 April 2005 


\section{APPENDIX 4: NAM AIDSMAP CALL FOR RESEARCH PARTICIPANTS}

From: hivweekly@nam.org.uk [mailto:hivweekly@nam.org.uk]

Sent: 16 May 2012 10:22

To: McTigue, Peter

Subject: HIV Weekly, 16 May 2012

nam

HIV Weekly, 16 May 2012

In this issue

herence and depression

rvical cancer

arting HIV treatment

patitis C

\section{Adherence and depression}

New US research has shown the importance for people with HIV of accessing treatment and care for depression.

Doctors in the US looked at the factors associated with adherence to HIV treatment.

Their headline finding was that African American people were about a third less likely to take $90 \%$ or more of their doses than people of other ethnic backgrounds (this level of adherence is considered necessary for treatment to be most effective). This is likely to be because of the difficult socioeconomic circumstances faced by many HIV-positive African Americans.

But a surprise finding of the research was that people with depression were $5 \%$ more likely to have high levels of adherence than people in the study who were not depressed.

The researchers think that this could be due to the beneficial effects of treatment with antidepressants.

People with depression who were taking antidepressants were twice as likely to take their HIV treatment as prescribed than people with depression who were not taking antidepressant therapy.

Depression is relatively common in people with HIV. You can access professional help and support through your HIV clinic, your GP or other local services. You can find out more about this subject in our booklet HIV, mental health and emotional wellbeing.

\section{Cervical cancer}

Taking HIV treatment reduces the risk of developing pre-cancerous cervical lesions, new research has shown. Cervical cancer is related to infection with certain strains of the human papillomavirus (HPV), a very common and often symptomless infection, which can lead to the development of cell changes and lesions that sometimes lead to cancer. In women with HIV, cervical cancer is considered to be an AIDS-defining illness.

New cases of the other AIDS-defining cancers - Kaposi's sarcoma and non-Hodgkin's lymphoma - have fallen dramatically since effective HIV treatment became available. Antiretroviral therapy has also been shown to improve outcomes in people who have these cancers.

Doctors in South Africa wanted to see if HIV treatment also had benefits regarding cervical cancer.

They therefore monitored 1123 women between 2003 and 2009. All had at least two cervical smears, a type of screening to identify signs of cells changing.

Only $2 \%$ of women were taking HIV treatment at the start of the study, but this increased to $17 \%$ as the research progressed.

Taking HIV treatment reduced the risk of developing pre-cancerous cervical lesions by $38 \%$.

It also had benefits for women who had pre-existing lesions, more than doubling the chances of regression (an improvement in symptoms).

Routine HIV care should involve regular cervical screening. This means that any abnormal cells can be spotted early and appropriate treatment can be provided. In the UK, women with HIV are recommended to have cervical screening (sometimes called a Pap smear or smear test) annually. Talk to your HIV clinic or GP to arrange screening. 


\section{Starting HIV treatment}

Starting HIV treatment based on ritonavir-boosted atazanavir (Reyataz) is more likely to suppress viral load to an undetectable level within six months than therapy containing efavirenz (Sustiva, also in the combination pill Atripla), Canadian research suggests.

The researchers monitored the viral load of over 1100 people who started HIV treatment between 2000 and 2009. Clinical trials often exclude people who inject drugs because of concerns they will not take treatment as prescribed. Unusually, many of the people in this study had a history of injecting drug use.

Overall, $68 \%$ of people had an undetectable viral load six months after starting treatment. This included a third of people who injected drugs.

For people with no history of injecting drug use, a combination that included ritonavir-boosted atazanavir was about $50 \%$ more likely to suppress viral load than a combination based on efavirenz.

Atazanavir/ritonavir appeared to be an especially good option for injecting drug users, doubling the chances of viral suppression compared to efavirenz.

The researchers therefore think that a combination based on ritonavir-boosted atazanavir may be a good choice for people who inject drugs or who struggle with adherence.

Want to talk to a healthcare professional about HIV treatment, but not sure where to start? Try our online Talking points tool before your next appointment.

\section{Hepatitis C}

Standard treatment for hepatitis $C$ consists of pegylated interferon and ribavirin. Treatment for hepatitis $C$ aims to cure the condition, but this doesn't always work and treatment can cause side-effects.

As with HIV drugs, hepatitis $\mathrm{C}$ drugs are grouped into different classes, or types. Two new hepatitis $\mathrm{C}$ protease inhibitors have been approved, but these have to be taken with the current standard treatment. However, a number of other new drugs are in development.

A major side-effect of pegylated interferon is depression. Doctors in the US have published an article stressing that people taking this therapy should be screened for depression. They also recommend that people with depression should receive treatment with antidepressants.

Research into new hepatitis C drugs means that treatment that doesn't involve interferon may soon be a reality. A study presented to the recent International Liver Congress showed that a combination of three hepatitis $\mathrm{C}$ drugs (ribavirin taken with a protease inhibitor currently called $\mathrm{BI} 201335$; and a non-nucleoside polymerase inhibitor currently called BI 207127) achieved a sustained virological response (considered to be a cure) in 68\% of people with genotype 1 .

The response rate for people with cirrhosis was up to 57\%. This is an important result for this group, as people with advanced liver disease are urgently in need of treatment options.

Ribavirin can also cause side-effects, most notably anaemia. New research involving people taking the two new hepatitis $\mathrm{C}$ protease inhibitors showed that this can be managed by reducing the ribavirin dose.

\section{AIDS 2012}

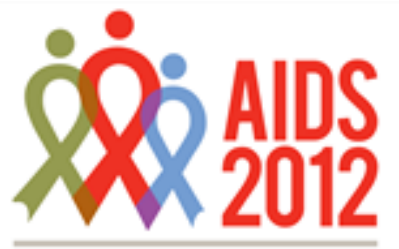

XIX INTERNATIONAL AIDS

CONFERENCE JULY 22 - 27

WASHINGTON DC USA

NAM is an official provider of online news for the International AIDS Conference (AIDS 2012). The conference is being held in Washington DC, 22nd-27th July.

A small number of late breaker abstracts will be accepted for oral presentation or poster exhibition. The same submission rules apply for the late breaker abstracts as for regular abstracts, but each presenting author may only present one late breaker abstract. Late breaker abstract submission is open until 22 May 2012. For more information on abstracts and late breaker submission please visit: www. aids2012.org/abstracts.aspx.

If you want to bring the conference to you, you can apply to host a conference hub, at which recordings of the conference sessions are screened and discussed. Applications to host a conference hub can be submitted through the conference website.

\section{Full speed ahead to curing hepatitis C}




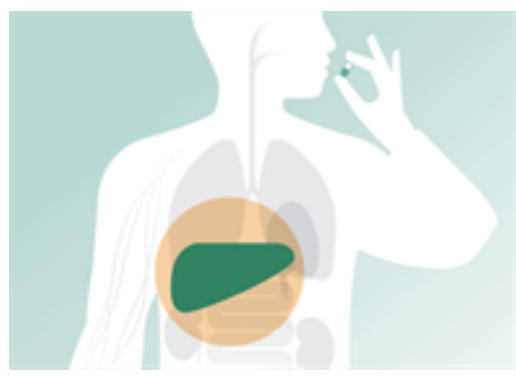

new era of hepatitis $C$ treatment.

The recent edition of HIV treatment update investigated the new drugs ushering in a Read online $>>$

\section{New tests speeding up TB diagnosis}

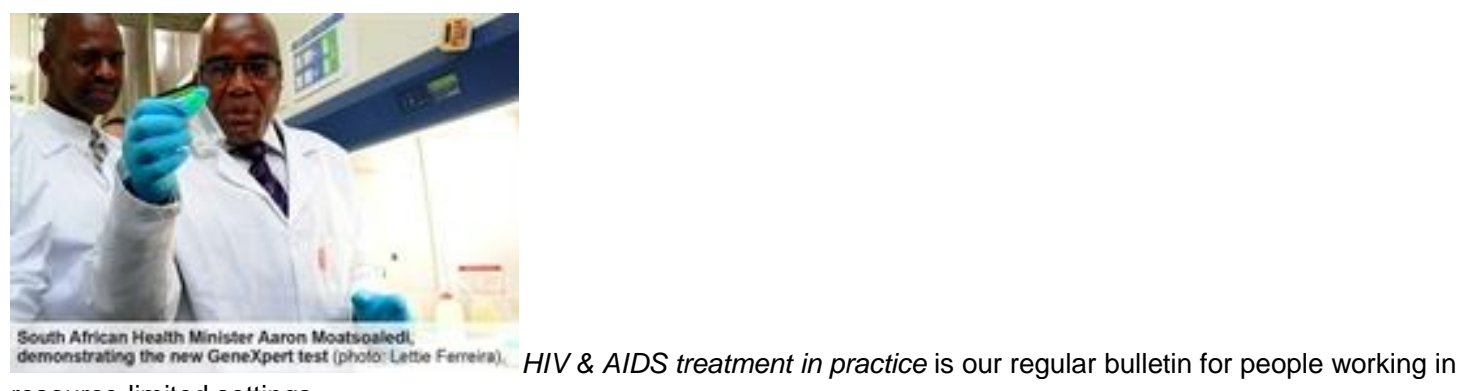
resource-limited settings.

The current edition looks at the role of new diagnostic tests for tuberculosis (TB) in supporting active case finding for TB. Read online >>

\section{Anti-HIV drugs booklet}

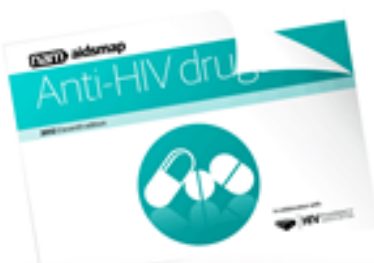

Revised and updated to include the newest HIV treatment options, the eleventh edition of our booklet Anti-HIV drugs is now available at www. aidsmap.com/booklets.

With information on individual drugs, including side-effects and key drug interactions, it aims to help you decide what questions to ask your doctor about starting or changing treatment.

If you work in a clinic or support group in the UK, you can order multiple copies free of charge. To order copies contact us at info@nam.org.uk or call 02032420820.

Read online or download pdf $>>$

\section{Research on employment}

\section{NOTTINGHAM LAW SCHOOL}

\section{Nottingham Trent University} The research covers employment, HIV discrimination and the law.

All information would be kept strictly confidential. It is hoped that the work will improve understanding of the issues faced by people living with HIV in employment and inform future policy decisions.

For more information contact peter.mctigue@ntu.ac.uk.

For more details, please contact NAM 
tel: $+44(0) 2032420820$

fax: $+44(0) 2032420839$

email: info@nam.org.uk

web: www.aidsmap.com

NAM Publications

Registered office: 77a Tradescant Road,

London, SW8 1XJ

Company limited by guarantee. Registered in England \& Wales, number: 2707596

Registered charity, number: 1011220

To unsubscribe from this email, please visit www.aidsmap.com/page/1492854/ 


\section{APPENDIX 5: THT CALL FOR RESEARCH \\ PARTICIPANTS}

\section{Opportunity to participate in research}

$(1 / 1)$

\section{UK CAB Moderator:}

Peter McTigure is carrying out a study about the experiences people living with HIV have in employment. He is looking for people diagnosed with HIV who are currently working, to discuss their experiences. So far, he has had trouble recruiting African people for the study, and so he is concerned that the results will not fairly reflect all the experiences of people living with HIV. If you are interested, are currently employed and would like to take part, please see the details below, and contact Peter on the details at the end if you would like to find out more.

My name is Peter McTigue. I work as a Lecturer in Law at Nottingham Trent University and I am looking for people living with HIV/AIDS who would be interested in being interviewed for a project I am currently undertaking.

Aims of the project

I am researching the difficulties faced by people living with HIV/AIDS within employment. The main focus is evaluating whether it was a good idea for people living with HIV/AIDS to be classed as "disabled" under the Equality Act 2010. I am interested in finding out whether you were aware the law treated you in this way, whether you think this is a good idea, what your experiences of working with HIV are and whether the law could be changed to better protect you.

Your contribution

If you are interested in taking part then I would like to conduct an interview (of up to about an hour long), in which I would like to discuss your own experiences of working with HIV/AIDS. I would like to talk to you about things such as whether you have disclosed your status to your boss or colleagues and, if so, what their reaction was like. I would also like to talk to you about your any problems that HIV/AIDS causes you at work and ways in which these might be overcome. 
I would like to audio record the interviews, since this will enable me to listen to what you are saying more at the time, rather than having to write lots of notes. It also means that I will have a precise record of what you have said. Please note that I will use a number of measures to ensure your data is kept confidential, and that you remain anonymous.

Please note that I will conduct the interviews at whatever time and location suits you best. I am more than happy to travel to you and I'm also more than happy to conduct the interviews in the evenings or at weekends.

What's in it for you?

It is hoped that you will find participating in the research an interesting and useful experience. The research will also hopefully improve your awareness of your legal rights as person living with HIV/AIDS. Once the research has been completed I will also provide you with a summary of its key findings.

I'm interested. How do I contact you?

Peter McTigue

Nottingham Trent University

Burton Street

Nottingham

NG1 4BU

Email: peter.mctigue@ntu.ac.uk

Telephone: 01158484220

Navigation

[0] Message index 


\section{APPENDIX 6: INTERVIEW SCHEDULE}

1. Provide Info Sheet and tell them about research

2. Complete Consent Form

3. Complete questionnaire

A broad and open invitation for the respondent to tell me a little about their social background, history and current health.

What has been your employment history?

Where are you employed now?

What type of working relationship do you have with:

- your boss?

- Your colleagues?

Have you disclosed the fact that you are HIV positive to your current employer?

If yes:

-who?

- describe the experience

- what was life at work like following disclosure? Examples.

- on reflection, was it the correct decision. Why?

- is it easier to manage your condition now you have disclosed? Why?

If no:

- why not?

- what factors prevent you from disclosing?

- do you think that your decision might change in the future?

Have you ever disclosed the fact that you are HIV positive to an employer?

If yes:

-who?

- describe the experience

- what was life at work like following disclosure? Examples.

- on reflection, was it the correct decision. Why? Why?

- is it easier to manage your condition now you have disclosed?

If no:

- why not?

- what factors prevent you from disclosing?

- do you think that your decision might change in the future?

(For MSM - Has the fact that you are HIV positive ever influenced your decision to disclose or not disclose your sexual orientation to an employer?) 
Have you ever had to complete a pre-employment health questionnaire? If yes:- describe to me how that fitted in with your decision to disclose (or not disclose) that we have just discussed.

If no:- how comfortable would you feel with disclosing your status in this manner? Would you?

Have you ever been subjected to discrimination at work because of your HIV status?

If yes - examples.

- How did that make you feel?

- What happened?

- did you take any action?

- How did the matter end?

Have you ever been subjected to discrimination at work because of any other ground?

If yes - examples.

- How did that make you feel?

- What happened?

- did you take any action?

- How did the matter end?

- (If they had disclosed HIV status) Do you think this was linked in any way to your HIV? Explain?

Do you worry about being discriminated against at work?

If yes: explore on what grounds - HIV, sexuality, race, etc

Do you ever fear for your job security because you are HIV positive?

Do you think there are factors or barriers which make it more difficult for you to do your job e.g. travel abroad, inflexible hours, lack of awareness of HIV? Examples

Does your company offer any benefits that you have been unable to access because of your HIV status e.g. health insurance, pension, etc? Examples

Is there anything your company could do to assist you at work? Examples

Explain working of Equality Act - explain PLHA are "disabled" and protected from discrimination.

Ask whether aware that PLHA are protected under the Act.

Do you think this is a good idea? Why or why not?

Would you consider yourself to be disabled?

Why or Why not?

If applying for a job, would you state on an application form that you were disabled?

Why or Why not? 
If haven't previously disclosed status - Bearing in mind the protection afforded to PLHA under the Equality Act, would you now feel more comfortable about disclosing your status? Why/Why not?

Explain the concept of reasonable adjustments to the respondent, then ask:

-Were you aware of this?

If yes: Have you ever requested reasonable adjustments?

If yes: describe what happened?

Were you satisfied with the outcome?

-Do you think this is a good idea?

If haven't requested reasonable adjustments - Do you think the concept would be beneficial to you?

If haven't requested reasonable adjustments - Explain that they need to disclose their status to their employer in order to request reasonable adjustments?

- What do you think of the concept now?

(To respondents who have not previously requested reasonable adjustments).

Would you feel comfortable making a request for reasonable adjustments?

Finally - discuss any unusual responses to questionnaire

- is there anything else that wish to bring to my attention?

Thanks and conclude.

\section{Consider snowballing}




\section{APPENDIX 7: RESEARCH QUESTIONNAIRE}

\section{HIV and Employment \\ Questionnaire}

1. Name:

2. Are you...

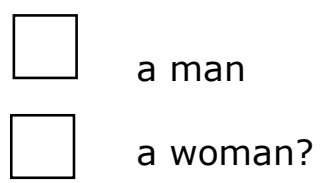

3. How old are you? years old

4. What is the first half of your postcode and the first digit of the second half? (e.g. B29 7, DE13 7, NG1 4)

5. Where were you born?

6. To which one of the following groups do you consider you belong?

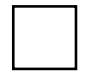

I am a man who has sex with other men

I am a heterosexual man who was born in

Africa

I am a heterosexual woman who was born in

Africa

I am a heterosexual man who wasn't born in

Africa

I am a heterosexual woman who wasn't born in

Africa 
Other - Please specify:

7. In what year were you first diagnosed with HIV or AIDS?

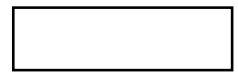

8. How many years in total have you been working for your current employer?

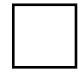

Less than 1 year

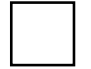

1 to less than 2 years

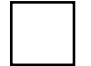

2 to less than 5 years

5 to less than 10 years

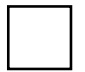

10 years or more

9. Do you work...

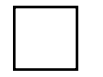

full-time

part-time?

10. How many hours per week do you currently work?

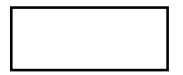

11. What is the full title of your main job e.g. Primary

School , Teacher, State Registered Nurse.

12. How would you classify your job? (Please tick one

only)

$\square$ Professional

Managerial \& Technical

Skilled Non-Manual 


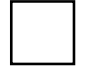

Skilled Manual

$\square$

Partly Skilled

Unskilled

$\square$

Other Please specify:

13. What is your highest level of educational

qualification? (Please tick one only)

Post-Graduate

Degree or equivalent

Higher Education

$\square$ GCE A Level or equivalent

GCSEs or equivalent

Other (Please specify:

14. What is your current salary? (Please circle one only)

Less than $£ 9,999$ a year

Between $£ 10,000$ to $£ 19,999$ a year

Between $£ 20,000$ to $£ 29,999$ a year

Between $£ 30,000$ to $£ 39,999$ a year

Between $£ 40,000$ to $£ 49,999$ a year

Between $£ 50,000$ to $£ 59,999$ a year

More than $£ 60,000$ a year 
15. What is your ethnic group?

\section{White}

$\square$ English/Welsh/Scottish/Northern Irish/British

$\square$ Irish

$\square$ Gypsy or Irish Traveller

Any other White background, please specify:

\section{Mixed/multiple ethnic groups}

White and Black Caribbean

$\square$ White and Black African

White and Asian

D Any other Mixed/multiple ethnic background, please specify:

\section{Asian/Asian British}

$\square$ Indian

$\square$ Pakistani

$\square$ Bangladeshi

\section{Chinese}

L

Any other Asian background, please specify:

\section{Black/African/Caribbean/Black British}

$\square$ African

$\square$ Caribbean

$\square$

Any other Black/African/Caribbean

background, please specify:

\section{Other ethnic group}


$\square$ Arab

Any other ethnic group, please specify:

Finally, if I need to speak to you again it would be great if you could provide some contact details:

Home telephone number:

Is it OK to leave a message on this number?

Mobile telephone number:

Is it OK to leave a message on this number? 


\title{
APPENDIX 8: CONFIRMATION OF ETHICAL
}

\section{APPROVAL}

\author{
Appendix 8
}

\section{Request for ethical review}

BLS Research Grants

\author{
Reply \\ 16/05/2016 \\ McTigue, Peter; \\ Wheat, Kay \\ Dear Peter
}

I write to confirm that your submission (No. 2010/39) to the College Research Ethics Committee (CREC) on 14 Sept 2010 requesting ethical clearance for the project entitled: Does English law adequately protect people living with HIV/AIDS within an employment relationship? was approved on 15 December 2010.

Yours sincerely, on behalf of, Kay Wheat

Chair CREC

\section{Ruth Russell-Jones}

College Research Support Administrator

College Research Support team, Business, Law and Social Sciences, Nottingham Trent University, Nottingham, NG1 4BU

Direct Tel: +44(0)1158484391

Fax: $\quad$ +44(0)115848 8700

Location: Chaucer Room 4704

E-mail: ruth.russelljones@ntu.ac.uk

Website: www.ntu.ac.uk 


\section{APPENDIX 9: RESEARCH BACKGROUND AND INFORMATION SHEET}

Thank you for the interest you have shown in taking part in this research project. Before you agree to participate, I would like you to read through the following information which will help to explain the project in more detail and what I'd like your input to be. If you have any questions about the project, or the nature of your participation which are not answered here, please do feel free to get in touch (contact details can be found at the end of this document).

\section{Aims of the project}

The broad aim of the project is to investigate and understand the difficulties faced by people living with HIV/AIDS within employment. The main focus is evaluating whether it was a good idea for people living with HIV/AIDS to be classed as "disabled" under the Equality Act 2010. I am interested in finding out whether you were aware the law treated you in this way, whether you think this is a good idea, what your experiences of working with HIV are and whether the law could be changed to better protect you. By understanding these issues, it is hoped that I will be able to make recommendations on how better protection can be afforded to people living with HIV/AIDS within employment.

\section{The researcher}

My name is Peter McTigue and I work as a Lecturer in Law at Nottingham Trent University. I am also a PhD student at the University and this work forms part of my PhD thesis.

\section{Funding for the project}

I am not receiving any funding for this project. In addition the work is being carried out in either my own time or time granted to me as part of my University research time allowance.

\section{Your contribution}

I would like to conduct an interview (of up to about an hour long), in which I would like to discuss your own experiences of working with HIV/AIDS. I would like to talk to you about things such as whether you have disclosed your status to your boss or colleagues and, if so, what their reaction was like. I would also like to talk to you about your any problems that HIV/AIDS causes you at work and ways in which these might be overcome.

I would like to audio record the interviews, since this will enable me to listen to what you are saying more at the time, rather than having to write lots of notes. It also means that I will have a precise record of what you have said.

\section{Storage and use of the data}


Once your interview has been recorded, it will be transferred on to my PC as a digital recording. I will then transcribe your interview. I will keep the recordings until the end of the project, after which they will be destroyed. Anonymised transcriptions will be kept for possible future analysis. It is intended that the research be published in one or more academic journals. Quotes from your interview may appear in such a publication, where they are deemed relevant to the interpretation of the data. In addition to myself my supervisors, Kay Wheat and Michael Keenan, may also proof read my work.

\section{Anonymity and confidentiality}

I will use a number of measures to ensure your data is kept confidential, and that you remain anonymous. Any files (digital audio and textual) which contain data will be kept securely on a PC and backup storage device in a password protected folder. Your name will be removed from any data that is published will not be linked to your name, or initials. In addition, anything you mention in your interview which could be used to identify you will not be published.

\section{Your rights}

There is absolutely no expectation that you must take part in this research project. Participation is entirely voluntary, and should you wish to withdraw at any time, you may do so and any data has not been transcribed or analysed up to that point will be destroyed. Data which has already been transcribed or analysed will however continue to be stored and used.

\section{Are there any disadvantages to me taking part?}

You will need to give up an hour of your time, but it is hoped that you find the interview interesting and useful enough to outweigh this draw upon your time. I intend to ask you about your HIV which may be a sensitive issue for you. However, if you feel that at any time you would prefer not to answer a question, that is absolutely fine.

\section{What's in it for you?}

It is hoped that you will find participating in the research an interesting and useful experience. The research will also hopefully improve your awareness of your legal rights as person living with HIV/AIDS.

\section{What if I am unhappy with the way the interview is conducted?}

If you are unhappy about any aspect of the interview, please tell me as soon as possible and I will seek to resolve the issue. If you have a complaint and would rather not discuss the issue with me then you can contact my supervisor Kay Wheat via Nottingham Trent University or kay.wheat@ntu.ac.uk

\section{What if I become upset or distressed following the interview?}

I will conduct the interview in a sensitive manner and if you become distressed, you have the right to not answer a question or indeed stop the interview. However if you become upset or distressed following the 
interview the following organisations will be offer advice, assistance and counselling:

THT Direct aim to provide information and offer support. They are also a gateway to services within Terrence Higgins Trust and services provided by other organisations.

You can phone them on 08088021221 between 10am and 10pm on Monday to Friday, and from 12 noon to $6 \mathrm{pm}$ on Saturday and Sunday. Emails can be sent to info@tht.org.uk.

Positively UK offer advice and support to women living with HIV. You can phone them on 0207713 0222. Women living with HIV answer their helpline from Monday to Friday $10 \mathrm{am}-1 \mathrm{pm}$ and $2 \mathrm{pm}-4 \mathrm{pm}$. They will also ring you back free of charge.

The African HIV Policy Network provides assistance to African people living with HIV/AIDS. Although, they do not offer directly counseling they are a gateway to services provided by other organisations. They can be contacted via telephone on 02070178910 during office hours or email at info@ahpn.org.

\section{Contact details}

Postal address:

Peter McTigue

Department of Academic Legal Studies

Nottingham Trent University

Burton Street

Nottingham

NG1 4BU

Email: peter.mctique@ntu.ac.uk

Telephone: 01158484220 


\title{
APPENDIX 10: CONSENT FORM
}

\author{
HIV and Employment \\ Voluntary participation consent form
}

\begin{abstract}
Please read and confirm your consent to being interviewed for this project by initialling the appropriate box(es) and signing and dating this form
\end{abstract}

1. I confirm that the purpose of the project has been explained to me, that I have been given information about it in writing, and that I have had the opportunity to ask questions about the research

2. I understand that my participation is voluntary, and that I am free to withdraw at any time without giving any reason and without any implications for my legal rights. I understand that once data analysis has begun, it will not be possible to withdraw my data from the study.

3. I give permission for the interview to be audio-recorded by the researcher, on the understanding that the recording will be destroyed at the end of the project.

4. I consent to my contact details being securely stored after the end of this project and to the possibility of being contacted in the future in order to take part in further research.

5. I agree to take part in this project

Name of participant

Date

Signature 